Florida International University

FIU Digital Commons

FIU Electronic Theses and Dissertations

University Graduate School

$11-1-2019$

\title{
A Genealogy of Neoliberal and Anti-neoliberal Resilience in the Ecuadorian Pacific coast
}

Vanessa Leon Leon

Escuela Superior Politecnica del Litoral, vleon015@fiu.edu

Follow this and additional works at: https://digitalcommons.fiu.edu/etd

Part of the Development Studies Commons, Human Geography Commons, Nature and Society Relations Commons, and the Social and Cultural Anthropology Commons

\section{Recommended Citation}

Leon Leon, Vanessa, "A Genealogy of Neoliberal and Anti-neoliberal Resilience in the Ecuadorian Pacific coast" (2019). FIU Electronic Theses and Dissertations. 4345.

https://digitalcommons.fiu.edu/etd/4345

This work is brought to you for free and open access by the University Graduate School at FIU Digital Commons. It has been accepted for inclusion in FIU Electronic Theses and Dissertations by an authorized administrator of FIU Digital Commons. For more information, please contact dcc@fiu.edu. 


\section{FLORIDA INTERNATIONAL UNIVERSITY}

Miami, Florida

\section{A GENEALOGY OF NEOLIBERAL AND ANTI-NEOLIBERAL RESILIENCE IN THE ECUADORIAN PACIFIC COAST}

A dissertation submitted in partial fulfillment of the requirements for the degree of DOCTOR OF PHILOSOPHY

in

GLOBAL AND SOCIOCULTURAL STUDIES

by

Vanessa León León 
To: Dean John F. Stack, Jr.

Steven J. Green School of International and Public Affairs

This dissertation, written by Vanessa León León, and entitled A Genealogy of Neoliberal and Anti-neoliberal Resilience in the Ecuadorian Pacific Coast, having been approved in respect to style and intellectual content, is referred to you for judgment.

We have read this dissertation and recommend that it be approved.

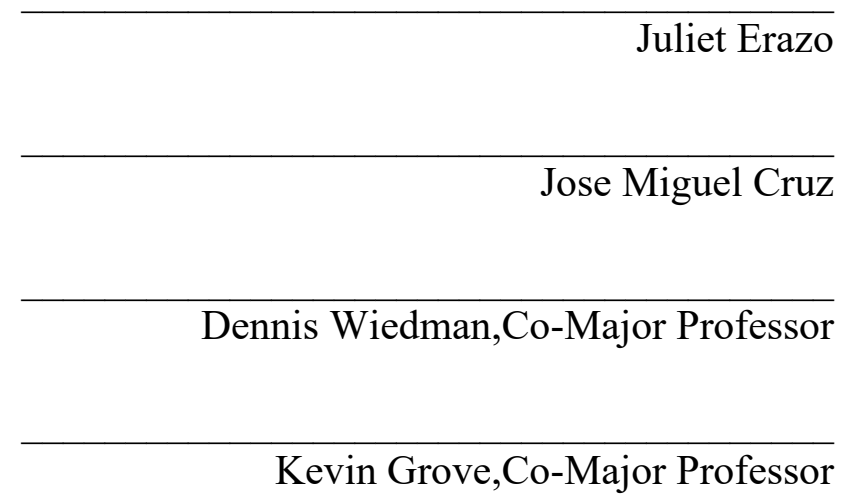

Date of Defense: November 1, 2019

The dissertation of Vanessa León León is approved.

Dean John F. Stack, Jr. Steven J. Green School of International and Public Affairs

Andrés G. Gil

Vice President for Research and Economic Development and Dean of the University Graduate School

Florida International University, 2019 
(C) Copyright 2019 by Vanessa León León

All rights reserved. 


\section{DEDICATION}

Dedicated to my beloved children Nicole and Emilio.

In memory of my dad, Dr. Carlos León.

And my endless gratitude to my husband Roger. 


\section{ACKNOWLEDGMENTS}

The accomplishment of dissertation writing was made possible thanks to the award of a two-semester Florida International University Dissertation Year Fellowship. The Tinker Field Research Grant, to which I am also thankful, provided me funds for my pre-dissertation research in the year 2015. My research also benefitted from the generous financial support of Ecuadorian National Secretary of Science of Technology, Ecuadorian institution that awarded me with a doctoral scholarship and the financial support of Escuela Superior Politécnica del Litoral (ESPOL), my hometown university.

I have been inspired by the work and expertise of my Major Professor, Kevin Grove, who believed in my research project and has been most helpful in educating me as to the complex analysis of resilience and biopolitics. The anthropological approach of this work has benefited from discussions with Dennis Wiedman. I appreciate his steady support since the first course in grad-school. I am also very grateful for the support and expertise of my dissertation committee members, Juliet Erazo, and Jose Miguel Cruz.

My fieldwork benefited from numerous persons to whom I express my gratefulness. A special thanks to Maria Isabel Cando and Yorgi Ramírez, visionaries of tourism development in Santa Elena. They introduced me to everyday life at Libertador Bolívar and provided me accommodation during my fieldwork. To Luis Coronado, a community leader, an artisan, and a writer, whose extreme bond to communal values and territory reveal what means to be a comunero. My friends Oswaldo Chancay and Milton Cordova, thanks for those conversations we had at the beach while you kindly provided me mouthwatering meals and delicious natural drinks. To ASOMAR members and other community leaders, Wilson Barzola, Carlos and Mónica Floreano, Liliam Floreano, 
Alexa Suarez, Cecibel Tomalá, Juan Reyes, my gratitude for the days amidst the sea, the sand, and the Atravezado river mouth.

Much appreciation to ESPOL President Cecilia Paredes Verduga, my friend, whose visits during the initial years of my grad-school largely contributed to keep me moving forward in this effort. This dissertation reunites several ESPOL professors whose careers are also connected to Santa Elena and the national administration. Enrique Sanchez, my dearest friend and mentor, my infinite gratitude. To Victor Osorio, thanks for sincerely share your experiences during the extended time he chaired CRMP. Much appreciation to Maria del Pilar Cornejo, who provided me valuable information about risk management in Ecuador and introduced me to several key informants at the Risk Management office. To Daniel Garces for elaborating the maps included in this work.

My gratitude to my mom, Maruja, who sheltered me each time I came back to Ecuador for doing fieldwork. I also want to thank my supportive friends in Miami, Carmen Helena, Cynthia, Jeanine, Paola, for the timely help they provided me (including dinners, coffees, flowers, parrilladas).

To my beloved family, I will never be able to give you back the time you waited for me while I was writing this dissertation. My dear daughter Nicole, a reader of my first essays, thanks for being so supportive. To my son Emilio, my companion, who took such tiresome travels during my fieldwork. And thank you, Roger David, my beloved husband, for motivating me to undertake this challenge and supporting me during my grad-school years.

Thank you, God, for inspiring me to write for and from my country Ecuador. 


\title{
ABSTRACT OF THE DISSERTATION \\ A GENEALOGY OF NEOLIBERAL AND ANTI-NEOLIBERAL RESILIENCE IN THE ECUADORIAN PACIFIC COAST
}

\author{
by \\ Vanessa León León \\ Florida International University, 2019 \\ Miami, Florida \\ Professor Kevin Grove, Co-Major Professor \\ Professor Dennis Wiedman, Co-Major Professor
}

Resilience appears to be everywhere, morphing and seducing global discourses, national governmental practices, and scholarship. Inasmuch as hegemonic discourses and national governments promote resilience through both disaster reduction and sustainable development policies, critical resilience scholars have emphasized resilience as a neoliberal security technique. By reinforcing resilience as a governmental practice embedded in neoliberal rationale, theory and practice are neglecting other areas to contextualize resilience. My dissertation traces a genealogy of neoliberal and antineoliberal State interventions underpinned by resilience thinking, organizing coastal rural lives in Ecuador. No matter the Ecuadorian governments' rationale, both genuflected to global hegemonic discourses on resilience that justify government intervention to secure the population's future. My analysis also reveals that both governmental rationales promoting resilience implemented similar techniques: legal framework adaptations, decentralizing processes, technocratic planning, and participatory management. 
After I captured resilience practices morphing through neoliberal and antineoliberal governance, a comprehensive ethnographic account also discloses unintended outcomes threatening the beach ecosystem. Ecosystems are a critical foundation of the socio-ecological relationship; however, profound changes in the beach ecosystem are now a consequence of the neoliberal and anti-neoliberal governmental emphasis on protecting the population and tourist infrastructure. More importantly, this research untangles resilience precepts underlying the neoliberal and anti-neoliberal problematization of nature to justify governmental intervention in coastal management. My particular critique of resilience does not replicate academic emphasis on catastrophic events. Hegemonic frameworks underrepresent the slow, local, and small emergencies by emphasizing acute and sudden events. However, resilience theory admits that continuous processes can also change the nature of a complex system. Thus, I focus on slow emergencies, those not regular, not acute emergencies, which also demand collective political or ethical response. My dissertation captures the constructive role of slow emergencies, frequently missed in disaster resilience analysis, to argue that resilience is a political process among nature, population, and governmental security techniques. The politics of resilience captures the social and cultural dimension of nature; then, nature emerges as an object of political struggles within complex, socio-ecological indeterminacy. 


\section{TABLE OF CONTENTS}

CHAPTER

PAGE

I. Neoliberal and anti-neoliberal resilience in the complex relationship among nature,

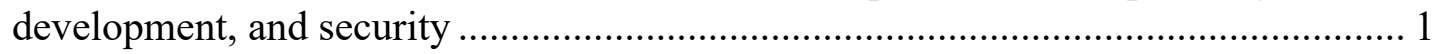

Life amidst tides and waves. Introduction ..................................................... 1

Theoretical framework: neoliberal and anti-neoliberal resilience .......................... 7

Methods: from a genealogy of resilience toward the politics of resilience ............. 18

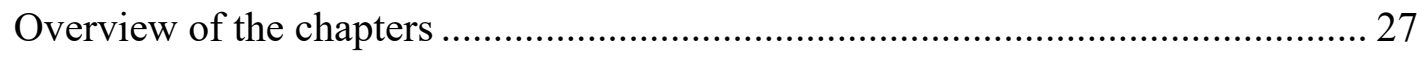

II. Untangling complex relations among state, government, population, and nature .... 31

The biopolitics of socio-nature governance ..................................................... 33

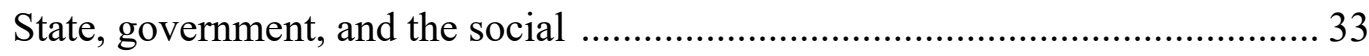

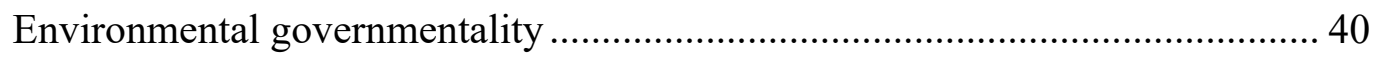

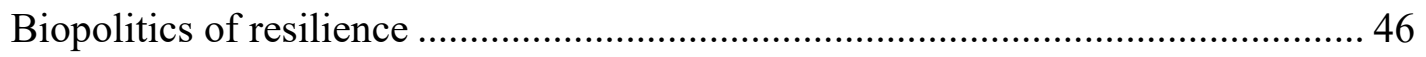

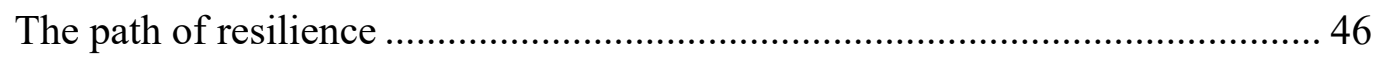

A biopolitical critique of resilience-building ................................................ 57

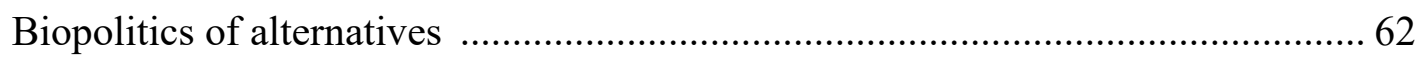

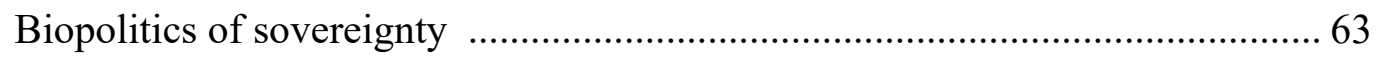

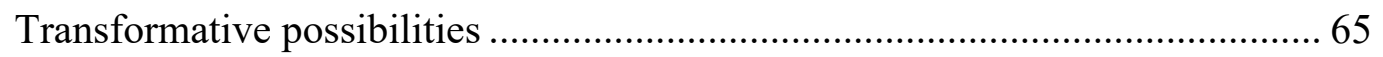

Conclusion: social research in entangled socio-nature governance....................... 68

III. Untangling Comuneros rural lives in the Ecuadorian Pacific coast ........................ 70

Ecuadorian governments and neoliberal policies, from the 1980 s to early 2000s... 73

A decade of anti-neoliberal state pracitce in Ecuador (2007-2017) ....................... 76

Struggles and adaptation in Santa Elena's rural coast ........................................ 83

Climatological issues in Santa Elena.......................................................... 87

Territory and communal management in Santa Elena ................................... 91

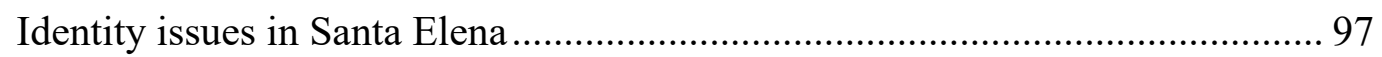

Development issues in Santa Elena............................................................. 102

Decision-making over territory, identity, and development in Libertador

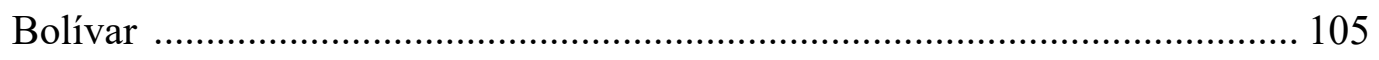

Conclusion: adaptive processes in Santa Elena .............................................. 110 
IV. Neoliberal and anti-neoliberal risk and disaster management in Ecuador 112

The neoliberal concern surrounding disasters in Ecuador .................................... 113

Dimensions of the Ecuadorian Civil Defense.............................................. 114

Disasters and the modernization of the state................................................... 116

ENSO lessons in Ecuadorian disaster management........................................ 120

Disaster management going into the twenty-first century ............................... 124

Anti-neoliberal resilience and a culture of risk in Ecuador .................................. 126

Adoption of international frameworks of resilience since 2007 ....................... 127

The anti-neoliberal integrated logic of resilience building ............................... 128

The anti-neoliberal risk management machinery pervading ecuadorian lives .. 134

Resilience building and risk management in the Province of Santa Elena............ 139

A biopolitical appraoch to social construction in Santa Elena ............................ 144

Armoring beaches: the structural measure to protect Santa Elena ..................... 147

The weakening of ecuadorian risk mangament ..................................................... 155

Conclusion: making resilient comuneros? .......................................................... 160

V. A different genealogy or resilience in Ecuador through integrated coastal resource

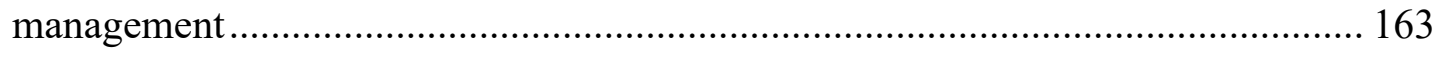

International concern on coastal management.................................................... 166

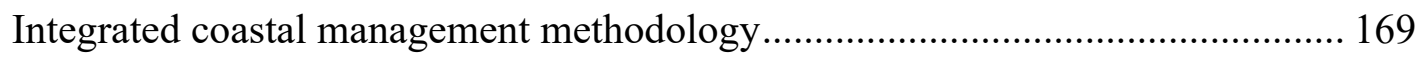

An adaptive model of coastal resource management ......................................... 173

Integrated coastal management in Ecuador ...................................................... 175

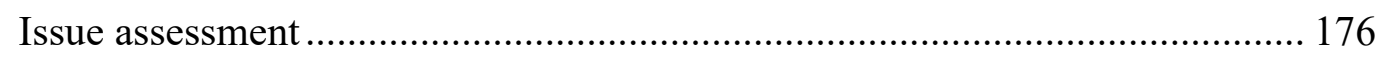

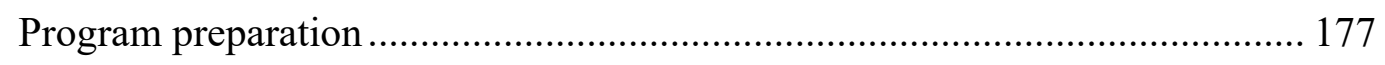

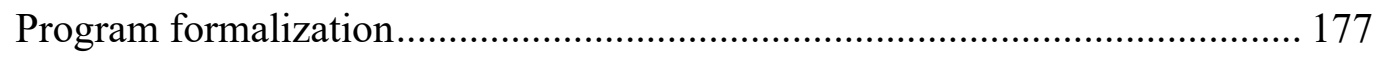

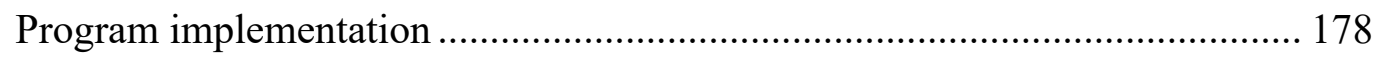

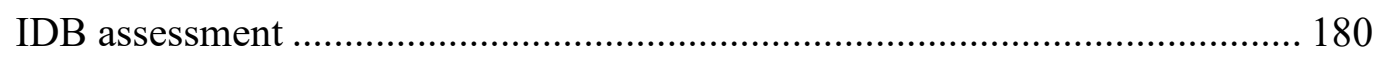

Ecuadorian coastal resource management program phase II ............................ 183

Integrated coastal management legacy in the coast of Ecuador ............................. 188

Conclusion: a connected but distinct genealogy of resilience in Ecuador............... 191

VI. Local emergencies and the politics of resilience ………...................................... 194

Neoliberal and anti-neolbieral tourism development management in Ecuador..... 196 
Tourism in Indigenous and rural common-property territories.......................... 199

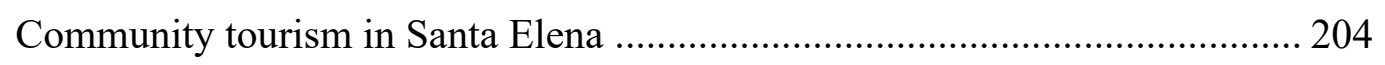

Tourism, beaches, and local threats in the seaside village of Libertador Bolívar . 207

Tourist beach management in a common-property territory ………………..... 210

Entanglements between tourism development and risk management policies . 215

Natural and human-made changes at the beach …………………………....... 219

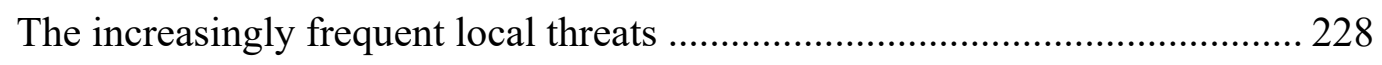

Conclusion: local threats, slow emergencies, and the politics of resilience...... 228

VII. Between development and security: the governmental problematization of

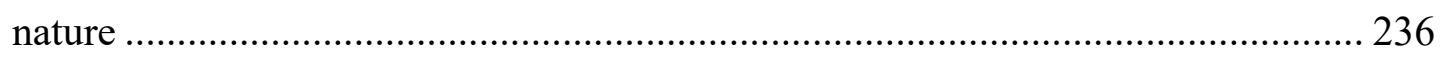

The ongoing problematization of nature in the coast of Ecuador ........................... 238

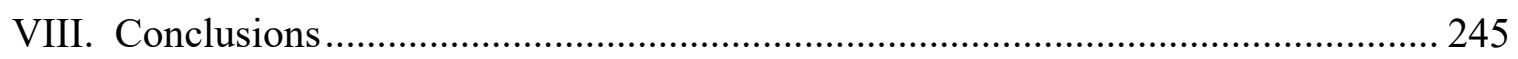

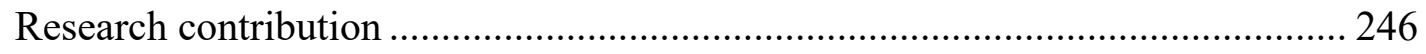

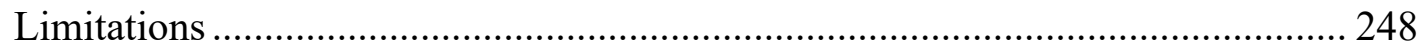

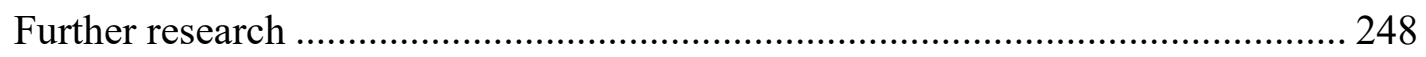

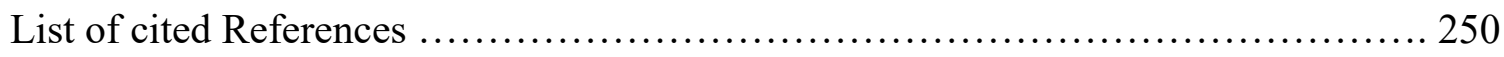

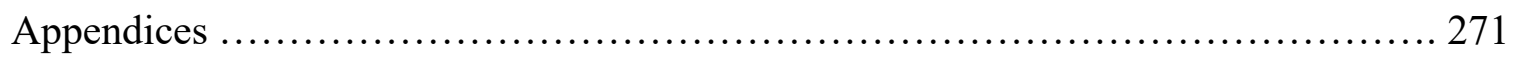

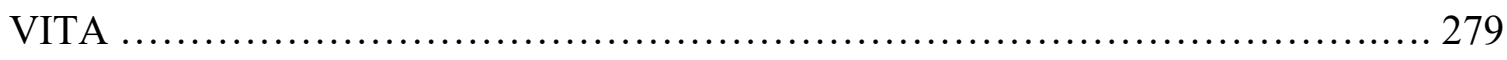




\section{LIST OF FIGURES}

FIGURE

PAGE

1. Map of Cantons in Santa Elena Province..................................... 3

2. Comuna Montañita in the 1970 s.......................................... 72

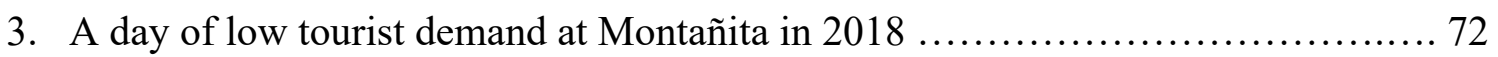

4. Map of Manglaralto Parish and coastal communities.......................... 85

5. Map of Libertador Bolívar and seaside comunas in Manglaralto Parish...........106

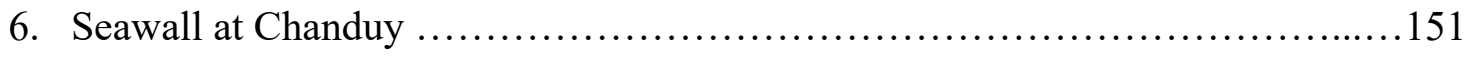

7. Coastal protection at Comuna La Entrada ................................... 152

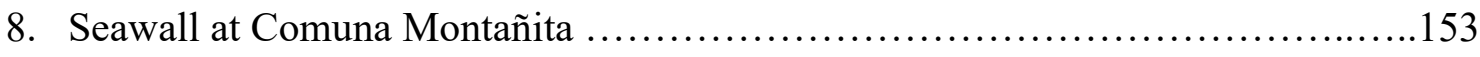

9. Seawall at Comuna Manglaralto ......................................... 153

10. River mouth of Atravezado River protection at Comuna Libertador Bolívar .......154

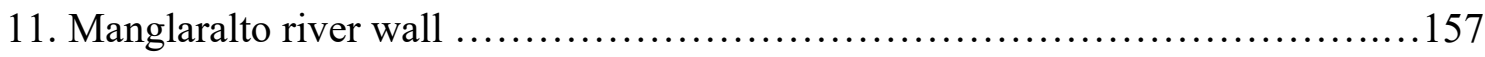

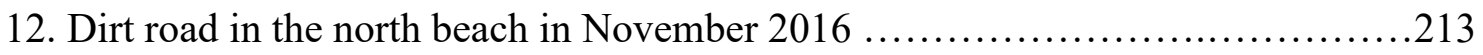

13. Damages at Libertador Bolívar south beach during November 2015 ..............221

14. Damages at Libertador Bolívar south beach during September 2018 ..............221

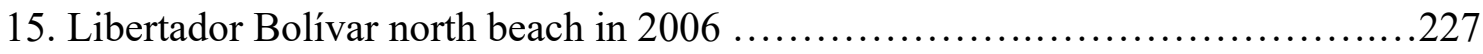

16. Anthropic effects at Libertador Bolívar north beach in 2016 ..................228

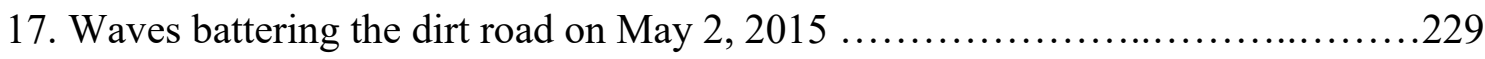




\section{ABBREVIATIONS AND ACRONYMS}

\begin{tabular}{|c|c|}
\hline ADG & Autonomous and Decentralized Governments \\
\hline BEDE & Ecuadorian State Bank \\
\hline CAS & Complex Adaptive Systems \\
\hline CBT & Community Based Tourism \\
\hline $\mathrm{CD}$ & Civil Defense \\
\hline CONAIE & Confederation of Indigenous Nationalities of Ecuador \\
\hline COPEFEN & $\begin{array}{l}\text { Coordination Office of the Program to Confront El Niño } \\
\text { Phenomena }\end{array}$ \\
\hline CORPECUADOR & $\begin{array}{l}\text { Executive Corporation for the Reconstruction of Zones Affected } \\
\text { by El Niño Phenomena }\end{array}$ \\
\hline CRC-URI & Coastal Resource Center of the University of Rhode Island \\
\hline CRMP & Coastal Resources Management Program \\
\hline $\mathrm{CT}$ & Community Tourism \\
\hline CTOAD & $\begin{array}{l}\text { General Code of Territorial Organization, Autonomies, and } \\
\text { Decentralization }\end{array}$ \\
\hline DIPECHO & $\begin{array}{l}\text { European Commission of Humanitarian Aid Disaster Preparedness } \\
\text { Program }\end{array}$ \\
\hline ENSO & El Niño Southern Oscillation \\
\hline EOC & Emergency Operation Committee \\
\hline EPFCT & Ecuadorian Plurinational Federation of Community Tourism \\
\hline GDP & Gross Domestic Product \\
\hline ICM & Integrated Coastal Management \\
\hline
\end{tabular}




$\begin{array}{ll}\text { IDB } & \text { Interamerican Development Bank } \\ \text { IMF } & \text { International Monetary Fund } \\ \text { LB } & \text { Libertador Bolívar } \\ \text { MT } & \text { Ecuadorian Ministry of Tourism } \\ \text { NGO } & \text { Non-Governmental Office } \\ \text { PHRA } & \text { National Public Health Regulation, Control and Vigilance Agency } \\ \text { PRODECOS } & \text { Community Ecotourism Program } \\ \text { RM } & \text { Risk Management } \\ \text { RMS } & \text { Ecuadorian Risk Management Secretariat } \\ \text { RPC } & \text { Rural Promotion Center } \\ \text { SES } & \text { Socio-ecological system } \\ \text { SD } & \text { United Nations Disaster and Risk Reduction office } \\ \text { TGW } & \text { Technical Working Groups } \\ \text { UN } & \text { United Nations } \\ & \text { Und }\end{array}$




\section{CHAPTER I}

\section{Neoliberal and anti-neoliberal resilience in the complex relationship among nature, development, and security}

\section{Life amidst tides and waves. Introduction}

Loud voices desperately cross the usually quiet seaside rural village of Libertador Bolívar, in the Pacific Coast of Ecuador. Some villagers are calling and urging other villagers to come down to the beach. Again, waves are battering the shoreline. It is the fourth time in less than two months that seawater fiercely runs up onto the beach, eventually damaging the tourist cabanas. Wooden sticks, pieces of roof, broken bamboo branches, electrical appliances float on the beach while the seawater runs unstoppably back into the ocean. Relentless waves continue breaking on the beach. Seawater uprushes again while the villagers desperately try to grab their business supplies and parts of the now shattered cabanas. A few seconds of high tides breaking into the beaches at Libertador Bolívar are enough to devastate the small-scale tourism businesses, the main contributor to the village's economy.

Libertador Bolívar is one of the sixty-eight native communities inhabiting the rural areas of Santa Elena, the southwestern Pacific province of Ecuador. Despite having an arid and dry climate (Garcia-Garizabal et al. 2017), the province of Santa Elena and its parishes (Figure 1) are prone to severe flooding increased during El Niño Southern Oscillation (ENSO), a very complex anomaly, which includes changes in the oceanographic and the atmospheric systems with worldwide consequences in different 
levels and different seasons (Gasparri et. al. 1999). Since recording began, ENSO has catastrophically impacted Latin American countries several times (Santos 2006), particularly the Ecuadorian and Peruvian coasts. A report issued by the Corporación Andina de Fomento (CAF 1998), the Latin American Development Bank, states that in Ecuador, ENSOs have generated pluviometry levels ranging between $40 \%$ and $130 \%$ over average rainfall during non-ENSO years. Furthermore, the extraordinary ENSO events in the years 1982-1983 and 1997-1998 increased the sea level by $0.20-0.40 \mathrm{~m}$ above the average, causing coastal erosion on the Ecuadorian shoreline (Cornejo 2007).

The 1997-1998 ENSO was the most severe natural disaster in Ecuador (Solberg et al. 2003). Damages equaled 17\% of Ecuadorian GDP (OPS 2000). The shrimp industry estimated a loss of US\$3.5 million and US\$4 million for the cost of shrimp farm recovery (Gasparri et al. 1999). In Libertador Bolívar and other rural communities of Manglaralto, the northern parish of Santa Elena, roughly $80 \%$ of the economically active population collected shrimp larvae during the 1990s (PMRC 1993). However, the 1997-1998 ENSO devastated the shrimp-larvae collection-led economy of those comunas (CAF 1998).

From 2007 onward, the government has implemented an early warning system, that monitors ENSO's repetitive but unpredictable behavior. In addition, the government promoted anticipatory methods and built mitigation infrastructure to reduce the possible damage ENSO can bring to the Ecuadorian coast (SGR 2012). ENSO monitoring and mitigation works are part of a governmental apparatus aiming to fulfill the constitutional duty to protect populations and secure future national development. 


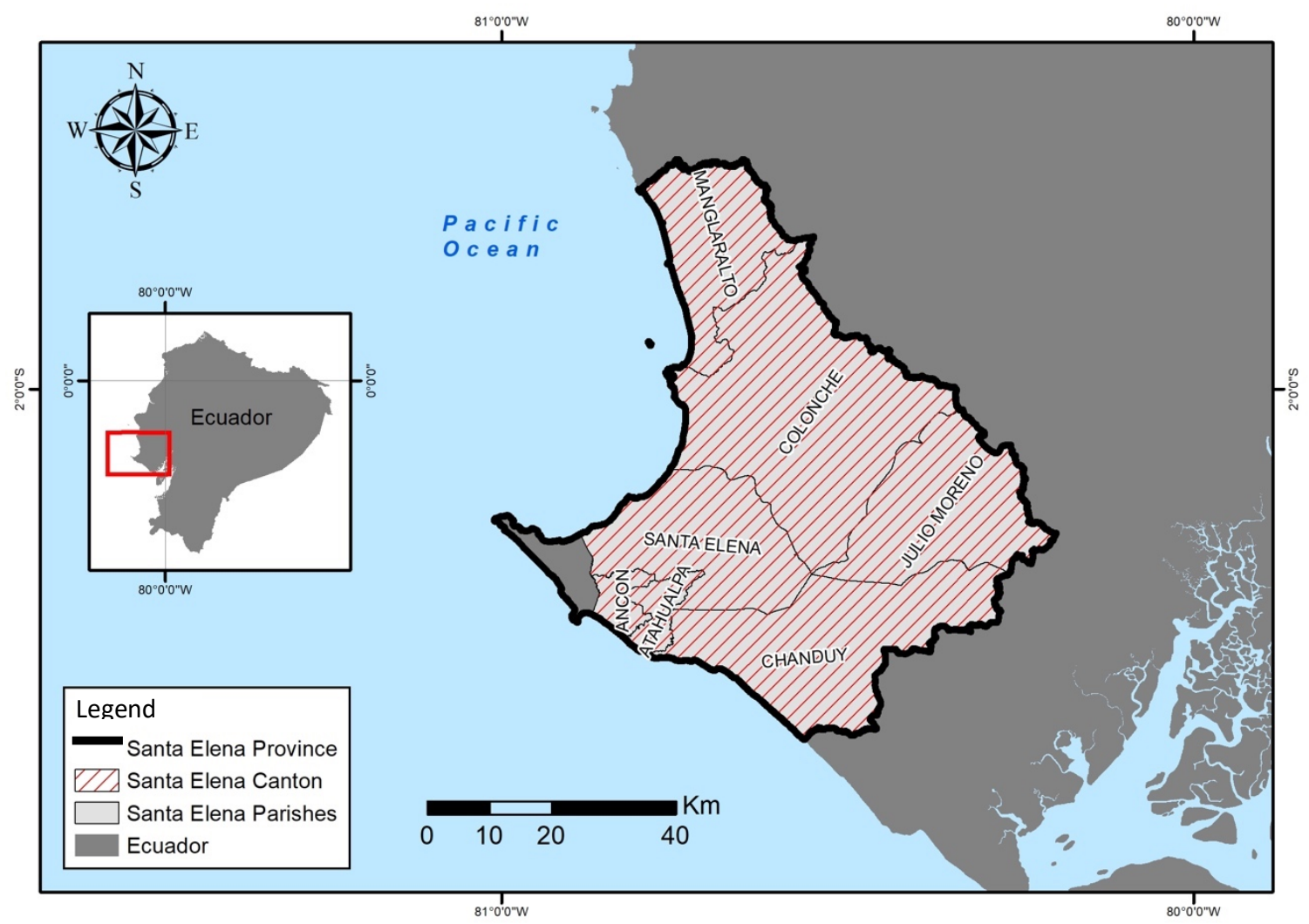

Figure 1 Map of Cantons in Santa Elena Province. Elaborated by Daniel Garces

Despite governmental efforts to protect the population from catastrophe, comuneros' economic survival is now at stake due to the constant struggle between waves, tides, and development of their small-scale tourism industry. In recent years, swells, increasing sea level, and the aguajes or spring tides are progressively affecting Santa Elena's beaches (SENPLADES 2017, GAD-PSE 2015, GAD-M 2014). For instance, on seven occasions from January to October 2015, waves battered seashore infrastructure at Libertador Bolívar (Sanchez 2015). August 2, 5, and 9, 2015 were particularly disastrous for this comuna. Waves reached the dirt road built next to the beach and damaged some cabanas, fences, and sewage pipes (Community Assembly, May 15, 2015). Later, on September 28, 2015 swells concurred with the Super Moon - 
moon's closest approach to earth-strongly affecting Libertador Bolívar beaches (Sanchez 2015). Tides, the gradual rise and fall of the sea level, result from the gravitational forces between the moon and the sun, and the rotation of the planet. During the full moon, tides rise higher than usual. Consequently, threats increase when swells coincide with the Super Moon. In other seaside comunas of Santa Elena, the conjunction of swells and tides also impacted (El Comercio 2015), and continues to impact, beaches (El Comercio, 2019). However, the effects are uneven and disconnected among the seaside comunas of Santa Elena. Waves do not impact Santa Elena's beaches in the same way or at the same time. Damages are local.

The constant threat of waves pummeling and flooding Santa Elena's beaches does not meet the categorization of a natural disaster. ENSO is catastrophic. It is an acute natural event that suddenly disrupts and changes coastal socio-ecosystems. On the contrary, the disruptions that waves and tides bring to the shore are small, local, and chronic. According to Davoudi (2012), unnoticeable internal processes or "chronic slow burns" can also change the "very nature of systems over time with or without an external disturbance" (302). Indeed, over time, the endless tidal increase and decrease of sea level erodes the beach. In populated coastal zones, waves and tides also damage infrastructure built next to the shoreline, such as the case of the comunas in Santa Elena. However, those cases do not attract global attention. Small and local effects of waves threatening the beaches of Santa Elena instantiate what Elizabeth Povinelli (2016) calls quasi-events, events that "never quite achieve the status of having occurred or taken place. They neither happen nor not happen" (13). Povinelli highlights the necessity of collecting 
quasi-events and connecting them to global processes. In doing so, they will inform place-specific contentions between huge and disastrous events.

In the case of Libertador Bolívar, those small episodes achieved the status of having occurred only after locals demanded governmental actions to protect the villagers and the village infrastructure. The aguaje on August 5, 2015, destroyed the north beach infrastructure in the comuna. Immediately afterward, the comuneros blocked the main highway claiming their constitutional right of protection. In response, an Emergency Operation Committee started to operate with the goal of effective mitigation intervention. Three days later, on August 8, 2015, local government staff declared the emergency in the comuna (Municipal Resolution No. 0108082015-IMSE-A). A temporary solution was to pile up some rocks in front of the beach. A long-term solution was a seawall built in the year 2017. Occasionally, waves have continued running up without disrupting comuneros' lives, however, on September 12, 2018, waves destroyed the south beach infrastructure at Libertador Bolívar (NicoPenínsula 2018). Immediately, a Community Assembly and local government appointed an emergency committee to address the issue (El Universo 2018, Community Assembly September 13, 2018). Since January 2019, an extension of the north beach seawall protects the south beach. However, seaward threats at Libertador Bolívar do not end, neither have they ended at other comunas, nor at any other coastal zone. Moreover, climate change is inducing stronger storms, sea-level rise and other seaward hazards on a global scale (McGrahan et al. 2007, Guzman et al. 2009).

Anderson et al. (2019) propose the descriptor slow emergencies to explain ordinary circumstances that demand urgent governmental action. Thus, the concept 
introduced by Anderson et al. counter the disaster-led emergency management promoted worldwide. Instead, slow emergencies highlight those not regular, not acute emergencies, which also demand collective political or ethical response. Thus, slow emergencies are constant and imperceptible episodes, locally endured by those who coexist with non or mis-recognized threats, argue Anderson et al. In the case of the Santa Elena's seaside comunas, there is a misrecognition of the increasingly frequent damages the waves cause to the local cash-strapped economy. Moreover, in Libertador Bolívar, the local government intervened only after comuneros protested on the streets, demanding that the government protect both the population and beach infrastructure. Recently, concerns over coastal erosion have been introduced at the national level (SENPLADES 2017); however, the impact on comuneros' livelihood continues to lack official attention. No doubt, the intensifying aguajes, stronger swells, sea-level rise and their unnoticeable effects are perceived as part of the nature of comuneros' lives.

My dissertation emphasizes small and chronic disruptions rather than welldocumented catastrophic events. In doing so, I posit a critique on global panaceas for local lives and environmental problems (Ostrom et al. 2007). Thus, when focusing on local and chronic disruptions, the spotlight on the political ecology of resilience turns toward the internal processes within the social, ecological, economical and the political interplay. In the next section, I explain the theoretical framework guiding my thinking, more broadly explained in chapter 2 . Next, I detail the methods that constituted my research, and my positionality as an Ecuadorian, born and raised on the coast. I will conclude this chapter with an overview of each of the chapters of my dissertation. 


\section{Theoretical framework: neoliberal and anti-neoliberal resilience}

I borrow from Anderson et al. (2019) the concept of slow emergencies to amplify critical work on emergency claims on the coast of Ecuador. The notion of emergency claims, according to Anderson et al., point out a distinction between the normal notion of emergency - which the government assigns to those formally recognized emergencies structured through uncertainty and risk - and those ordinary situations that also demand some urgent response. Emergency governance in Santa Elena mainly emerged from the technical analysis of the Ecuadorian Risk Management Secretariat (RMS), as I document in chapter 4. Thus, top-down risk and disaster management has mapped risk and vulnerabilities throughout the country. RMS has also built social and engineered mitigation capabilities at local levels in accordance with global criteria on resilience building. However, in the case of Libertador Bolívar, the ordinary threats to the tourismbased economy are growing in frequency since global environmental changes are affecting wave and tide behavior. They are slow emergencies that require governmental intervention. Indeed, the government built a seawall to protect beach infrastructure. Consequently, governmental emergency responses in Santa Elena have also emerged from the local, after comuneros' emergency claims appeared.

The beach is very significant in comuneros' everyday lives. After the ENSO 1982-1983, comuneros' economy relied on shrimp-larvae harvesting. However, after the 1997-1998 ENSO, when natural shrimp-larvae almost disappeared, the comuneros decided to venture into tourist development (see chapter 3). Supported and assisted by a long-lasting national coastal management program, the comuneros realized the economic and recreational value of the beach ecosystem (see chapter 5). Nowadays, the comuneros 
are owners of small-scale tourism businesses while they make collective decisions on future developments in Community Assemblies, a customary and legal form of ruling common-property lands in Ecuador. Most of the small-scale tourism businesses of Santa Elena are built in what the RMS declared "risky zones", where edifices are banned. In Libertador Bolívar, the most visited restaurants operate on an unstable cliff on the south beach. In the recently developed north beach, comuneros built their cabanas on the shore, next to the river mouth. Since RMS bans construction in those areas, the Ministry of Tourism cannot issue tourist operation certification to most of the tourist businesses at Libertador Bolívar and several other communities in Santa Elena. Indeed, comuneros' livelihoods continue to play out where national policies do not match. Thus, national policies have become part of the socio-ecological entanglement in the ordinary lives of comuneros. It is in those interstices of governmental coastal management that comuneros demand actions for their development and security.

Since the early 2000s, resilience thinking, pursuing environmental and societal security, has pervaded worldwide governance. The most imprinted concept of resilience, which derives from the UN Disaster and Risk Reduction (UNDRR) framework, aims to increase communities' response and adaptive capacities to confront disasters (McEvoy et al. 2013, Chandler and Reid 2016). Consequently, individuals and communities increase resilience and reduce vulnerability to natural and anthropic (human-made) threats through governmental policies and programs. In disaster management, resilience building was formally institutionalized through the hegemonic Hyogo framework for Action 20052015, endorsed by the UN General Assembly (Grove 2013a, 2014a). Ecuador engaged such framework through the Comité Andino de Naciones or Andean Nations Committee, 
while regional concerns on disaster management emerged (Rebotier 2016). Worldwide, the concept of resilience grew exponentially post $9 / 11$, when global insecurities located resilience within security discourses and policies (Chandler 2012; Mulligan et al. 2016). According to the UNDRR webpage, one hundred thirty countries are building resilience under the light of the Sendai Framework for Disaster Risk Reduction 2015-2030 (issued after the Hyogo framework), while sixty-five countries have developed national platforms which provide recommendations toward a post-2015 framework.

The increasing inclusion of resilience thinking in state practices has drawn the attention of critical social scientists, who have unpacked the hidden effects of promoting resilience policies. For instance, Dunn et al. (2015) argue that governmental programs to build resilience create a desirable resilient subject prepared to deal with change. However, Dunn et al. also reveal that the desirable resilient subject: 1) responds according to governmental rationale, and 2) eventually, becomes a subject in constant need of state intervention. Paradoxically, the premise of resilience building cultivates within the State, the moral obligation to enhance citizens' own responsibility to secure life (Chandler and Reid 2016). Moreover, Davoudi and Madanipour (2015) argue, "when resilience is used in the social context, the principle of self-organization is translated into self-reliance" (21). Thus, resilience building transfers security responsibility to individuals or communities.

Furthermore, governments advocate numerous strategies to achieve the goal of building more resilient communities and individuals. However, Kevin Grove (2013b, 2014b) reveals that mechanisms applied by resilience building programs - such as planning, participatory processes, training-actually order locals' relations with others 
and modify local knowledge. Consequently, resilience building removes possibilities of freedom and political action (Grove and Chandler 2017). Furthermore, argues Grove (2018), resilience thinking inhibits collective capacities "to imagine and bring about possibilities for different forms of life not organized around institutions such as private property, the market, and the territorially based nation-state" (Grove 2018a, 22). Thus, critical approaches to resilience thinking reveal that it actually counters resilience theory's main theoretical pillars, based on complexity, non-linearity, and emergent outcomes.

However, resilience "appears now to be everywhere," argues Ben Anderson $(2015,60)$ in his article questioning "What kind of thing is resilience?" The reason for resilience becoming a ubiquitous term, argues Anderson (2015), relies on the "seductiveness of resilience as it morphs and changes" (62) through "complex fields alongside other ways of governing life" (64). Anderson's arguments join critical scholarship currently showing that resilience has become an essential component of neoliberal governance (Anderson 2010, Chandler 2012, Chandler 2014, Frerks 2011, Grove 2013a, Joseph 2013, O'Hare \& White 2013). Governments that adopt neoliberal policies advocate for supposedly universal recipes, rely on experts' economic management, and deploy invasive and participatory policies, while pursuing a marketbased equilibrium (Peck and Tickell 2002).

Responding to market, commerce, and commodities, subjects become active consumers and entrepreneurs (Barnett 2005). Thus, the market determines appropriate government action, excluding State calculation of social welfare. Consequently, neoliberal practices decentralize responsibilities to local institutions and individuals 
(Peck and Tickell 2002). In line with neoliberalism, resilience also advocates for decentralized responsibility on a local scale. Indeed, resilience appeals for security by inculcating anticipatory criteria among individuals (Smith 2015, Coaffee \& Fussey 2015). Important for this dissertation, neoliberalism and resilience are grounded on rejecting predictability and managing complexity with tools such as contingency plans or crisis prevention (Walker and Cooper 2011). Consequently, argue Walker and Cooper (2011), resilience colonized global policies after fitting neoliberal ontology in complex systems.

In Ecuador, the government formally adopted and implemented UN resilience frameworks from 2007 through 2017. It was a decade ruled by an openly socialist and anti-neoliberal government (Gamso 2016, Becker 2013). In rejecting neoliberal state practices, Ecuador followed the socialist and anti-neoliberal trend enveloping Latin America since the late 1990s. According to Walsh, the left-led ideology pervading Latin America "purport[ed] to break with neoliberalism and construct different social, political, and economic orders" (2015:19). Despite the leftist resurgence in Latin America being called post-neoliberalism (Macdonald and Ruckert 2009, Radcliffe 2012), this dissertation focuses on the rejection of neoliberal state practices that guided the Ecuadorian left-led government. Thus, through the whole dissertation I focus on the antineoliberal rationale steering Ecuador for a decade. Overall, the anti-neoliberal discourse in Ecuador highlighted a detachment from market-driven logics while furthering the centralized and regulatory function of the state (SENPLADES 2013, Correa 2009).

The anti-neoliberal practices in Ecuador included rigorous planning and an administrative decentralization. The population's protection was one of the most critical 
concerns for the anti-neoliberal rationale ruling Ecuador. As stated in the 2008 Ecuadorian Constitution, article 389:

"The State shall protect its people, communities and nature against the adverse impacts of natural or human-made disasters through risk prevention, disaster mitigation, restoration and improvement of social, economic and environmental conditions, to minimize the condition of vulnerability."

Thus, the anti-neoliberal government in Ecuador created a risk management national system, which, according to Maria del Pilar Cornejo -first Risk Management Secretary, "aimed to confront adverse events, recurrent or not, in a way that would not affect Ecuadorians' properties, economy and life" (interview with author, June 12 2018). Mainly, the RMS implemented anticipatory methods to mitigate natural and anthropic disasters throughout the country (see Chapter 4). Furthermore, the Ecuadorian antineoliberal government tied resilience to Indigenous and rural livelihoods, where catastrophic events had previously devastated the local economy (Rebotier 2016). Indeed, Ecuador had faced many natural and anthropic disasters during the 1990s (Demoraes \& D'Ercole 2001, Solberg et al. 2003). On the coast, the 1997-1998 ENSO left hard lessons that paved the way for disaster management policies (CAF 1998). However, thengovernments, characterized by adopting neoliberal state practices, did not achieve a national system of disaster and risk management as the anti-neoliberal government accomplished in a single decade. Therefore, in Ecuador, resilience exceeds any simple equation with neoliberal rule. 
Drawing upon Ben Anderson's (2015) question of the nature of resilience, it is imperative to understand "how resilience transverses contexts," how it "changes across contexts" and how "an ethos moves across contexts" (62). In line with Anderson's call, critical scholarship has recently shown that resilience is tied up in ongoing and placespecific contestations over development and security (Brown 2016, Grove and Chandler 2017). Throughout my dissertation, I critically contextualize how resilience intersects with historical trajectories of coastal development and security, and with specific political-economic apparatuses ruling the country. In doing so, I address the malleability of resilience, as it flows smoothly in the complicated relationship among nature, development, and security.

To understand the contextually specific relationship between resilience and governmental rationales in Ecuador, this study will probe three key questions:

1. How does the Ecuadorian government approach, promote, and operationalize resilience in neoliberal and anti-neoliberal Ecuador?

2. How does the Ecuadorian government approach, promote, and operationalize tourist development in neoliberal and anti-neoliberal Ecuador?

3. How have comuneros strategically mobilized tourist development and resilience in response to both neoliberal and anti-neoliberal development? I argue that resilience is a political process among nature, population, and governmental security techniques. In the case of Santa Elena, the use (and abuse) of natural resources, individuals living in the interstices of policies, and governmental logics toward securing future wellbeing, configure dynamic and continuous subsets of political processes within the endless and complex human-in-nature relationship. An uneven 
political process between the three aforementioned techniques will lead to unnoticeable damage to nature, the population, and the world. Hence, the politics of resilience must capture the social and cultural dimension of nature, viewing it as an object of political struggles.

Firstly, my approach to nature in this dissertation focuses on coastal zones, which involve the interface between marine and terrestrial environments and the triple action of the sea, the land, and the air. Thus, coastal zones are dynamic areas incessantly influenced by other complex subsets of systems such as the gravitational forces between the moon, the sun and the earth, the wind, the ocean, the intertidal zone, geological attributes, population, and other stressors. In addition, the increasing global environmental changes threatening coastal zones increase the complexity and uncertainty in those areas. The delimitation of coastal zones' extension varies according to programs and legislation. McBride and Seminack (2017) define the landward and seaward limits of coastal zones based on the geomorphic regions. It includes the coastal plain or seaward edge, the shore face from the mean low-tide line to the average wave base $(5 \mathrm{~m}$ to $10 \mathrm{~m}$ water depth), and the continental shelf from average wave base to the shelf break. In Ecuador, coastal zone circumscribes from 50 meters (164.03 feet) seaward to the highest tide line, up to $50 \mathrm{~km}$ (31.06 miles) inland (PMRC 1993). Throughout my research I have worked with seaside comunas located in low-elevation coastal zones, or "the contiguous and hydrologically connected zone of land along with the coast and below $10 \mathrm{~m}$ of elevation" (Neumann et al. 2015, 3).

Secondly, in Santa Elena, the comuneros have historically resided next to the sea. They remain within coastal landscapes and withstand the threats they entail, such as high 
tides, ENSO, extreme rainfall and severe droughts. Migration out of the communities of Santa Elena is rare, due to the deep attachment comuneros have to their ancestral lands. Rather than relocate, they adapt to disturbances brought about by human influence, such as the Spanish Conquest or the Incas' invasion (Alvarez 1999) and by natural disruptions, such as ENSO. In the interval of those massive disruptions, the comuneros deal with misrecognized events, among them, waves severely battering the beaches, putting seaside villagers' livelihoods at risk, and mismatches between coastal management and tourism development, as I detail in Chapter 6.

Thirdly, by governmental security techniques, I refer to the "bundle of strategies, techniques, procedures, mechanisms, and practices through which authorities seek to make government programs operable" (Davoudi and Madanipour 2015, 5). Such "technologies of power" structure and shape the lives of individuals and the collective (Foucault 2007). They include institutional arrangements, material forms, and other kinds of processes providing "guiding norms and an oriented telos" (Collier 2009, 89). Such techniques aim to "normalize" social life by adapting to the problems of the population to redeploy state interventionism (Collier 2009). I disclose discourses and mechanisms Ecuadorian neoliberal or anti-neoliberal governance have deployed to achieve the insertion of policies based on concepts of resilience.

In my dissertation, I demonstrate how Ecuadorian governments, advocating discourses of resilience and sustainability under neoliberal or anti-neoliberal logics, problematize nature to justify the moral duty of protecting coastal zones. More importantly, the longitudinal analysis of such interventions reveals current counterproductive effects on the beach ecosystem. The environmental worth of the beach 
has been undervalued after the comuneros realized its recreational value. Yet, in synchrony, it provides the economic security of the comuna. Nonetheless, an uneven environmental, recreational, and economic value of the beach ecosystem does not promise environmental and economic security over time. In coastal zones, the growing tourist demand affects the previously pristine and undeveloped beaches (Adgel et al. 2005). Across the Pacific coast of Ecuador and many other coastal areas in the world, such as the Caribbean Islands (IRF 1996), Papua New Guinea (Diedrich et al. 2019), Indonesia (Cushnahan 2003), Malaysia (Hamzah \& Hampton 2013), small-scale tourismbusinesses have emerged as a means of improving locals' livelihoods. Furthermore, in other coastal regions of the world, small tourist ventures challenge the mass tourism economy (Smith and Eadington 1992, Weaver 2011). Accordingly, tourism of a smallscale nature should promote keeping coastal natural resources unaltered. Conversely, my research discloses the population's and government's rationales for pressuring the beach ecosystem in response to securing the tourism-led economy of Santa Elena.

The insights on the politics of resilience may be beneficial, particularly for decisions on coastal zone management, economic development models, and mitigation strategies on local and global scales. Firstly, sustainable development and risk management policies adopted in Ecuador emerge from the United Nations' global frameworks. However, those frameworks are not panaceas for local struggles where common property and decision making prevail over Western notions of the market, private property, and individual responsibility. Indeed, UNDRR frameworks adopted by Ecuador are part of those policies not reaching rural Ecuadorian lives. Secondly, the politics of resilience disclose the different ways people and the government approach 
risk. My case reveals a human logic to securing future progress that exceeds the national policy's perception of risk. It becomes important, considering populations settling in coastal zones. According to census data, in Ecuador roughly $45 \%$ of the population lives in one of the Pacific Coast provinces. Globally, the populace in coastal zones has doubled in less than two decades. Small and Nicholls (2003) estimated 1.2 billion people (23\% world's population) lived within $100 \mathrm{~km}$ of the coast in 1990. By June 2017, the Ocean Conference organized by the UN estimated that nearly 2.4 billion people (roughly $40 \%$ world's population) lived within proximity to the coast. The numbers are of greater importance in low-elevation coastal zones, where more than 600 million people (approximately 10\% world's population) reside despite increasing sea hazards.

My dissertation aims to move debates of resilience from a mere critique of the effects of resilience thinking to unveiling resilience in the realm of politics. What can inform the politics of resilience within policy making and academia? As previous paragraphs imparted, the common concern of the critical resilience scholarship lies in reducing "individual and collective capacities to act politically" (Grove 2018a, 22); and, consequently, alternative possibilities not arranged according to dominant institutions such as private property. Critical resilience scholars have adopted Michel Foucault's biopolitics, a concept developed for the analysis of power relations, to unfold resilience thinking as a mechanism of power "normalizing" collective lives. Accordingly, geographers approach biopolitics for a "spatialized analysis of power" that upholds "the centrality of the population" within the configuration of technologies of power (Philo 2007, 342). I turn to Foucault's notion of biopolitics as a "problem space for thinking through how life and power intertwine in contextually specific ways" (Grove 2018b, no 
pagination), to look into the unintended outcomes emerging from both, the interstices of regulatory mechanisms of security and populations' struggles with nature. In doing so, slow emergencies can capture the constructive role of feedback emerging from misrecognized episodes, where locals campaign for present and future security from the ground. My dissertation shows how transgressing critical resilience analysis on the effects of resilience unpacks harmful effects of resilience over nature. In doing so, I emphasize the complementary value of the ecosystem and the social system within a socio-ecological arrangement. In the next section, I expand on Foucault's examination of power relations to explain the methodological approach in my dissertation.

\section{Methods: from a genealogy of resilience toward the politics of resilience}

A biopolitical approach allows me to identify power relations among three main driving forces interplaying in my research: nature, population, and governmental techniques. However, how to study the indeterminacy of complexity is multifaceted. In my dissertation, I draw upon three reputable contributors to different but related fields of biopolitics. Firstly, Stephen Collier's (2011) model developed from analyzing the birth of biopolitics in Soviet modernity facilitates the comparison of the neoliberal and antineoliberal resilience governance in Ecuador. Secondly, I adopt Kevin Grove's (2018a) approach to resilience as a style of thought. Thirdly, Foucault's genealogy of power sheds light on tracing mechanisms of security centered in nature's need for intervention. In the next paragraphs, I clarify why these three are important for analyzing the indeterminacy of complexity. 
The reflection on neoliberal and anti-neoliberal rationales promoting resilience in Ecuador is categorical for my research. Here, my concern turns to the biopolitics of successive forms of governments, deeply analyzed by Stephen Collier (2011). Collier develops a model to compare state-led transformations of collective life promoted by socialist and neoliberal rationales in Russia. The model identifies an object of intervention and the analytical instruments for intervention. In my analysis, the rural life of Santa Elena, specifically the seaside comunas, are the object of intervention while policies on coastal management, risk management, and tourism development became main analytical instruments for intervention. Through this scrutiny, I unpack the rationale behind problematizing governmental intervention in coastal lives.

Within the multiple analyses on what kind of thing resilience is, Grove (2018a) addresses resilience as a style of thought which facilitates the understanding of indeterminacy. Illuminated by Grove, I approach resilience as a conceptual relation among humans, nature, and governmental mechanisms of security assembled in contexts of threats and change, which ultimately produce hidden effects over nature. Thus, resilience is not one thing, not a discourse or a policy, not a particular skill a government can enhance among the population. Resilience as a style of thought allowed me to keep in mind the initial approaches to socio-ecological resilience where, the ecological and the social, both function in a constant co-evolution (Berkes 2010). This co-evolution is complicated by the presence of external or internal disturbances and, moreover, by the technologies of power, which sometimes neglect feedback emerging from its own socioecological system. Thus, keeping in mind the socio-ecological indeterminacy, this dissertation untangles each layer within the complex systems that no-one "can neither 
fully know nor completely control"; layers where uncertainty and insecurity have become "problems of how to live with and manage complexity;" and layers "intervening in complexity in order to bring about desirable outcomes" (Grove 2018a, 20).

While resilience, as a style of thought, allows me to capture each layer and its interconnections, a genealogy of how resilience traverses social and ecological changes allows me to capture pieces of evidence in my longitudinal analysis. Michel Foucault called "genealogy" a methodology to trace techniques that governments create to discipline and secure populations. A genealogy addresses "what is specific about the mechanism of power at a given moment, for a given period, in a given field" (Foucault 2007, 17). According to Philo (1992), the genealogy developed by Michel Foucault "opens up a heightened sensitivity to the way in which space and place are inextricably bound up in the history" (137). It is crucial since the critique of resilience has explored how the aftermath of past events and hope in a desirable future shape the present (Dunn et al. 2015) in which people need to be prepared to confront and adapt to sudden and abrupt changes. However, rather than focusing on acute emergencies, I propose to capture Anderson et al.'s slow emergencies. Thus, a genealogy of how Ecuadorian governments have practiced resilience in coastal zones and how resilience has constituted a technique operating in multiple processes (Foucault 2007) allows me to capture the seduction of resilience, which morphs alongside ways of governing life (Anderson 2015).

I also apply a tool of causal interference called "process tracing," developed by David Collier (2011). Process Tracing is "an analytic tool for drawing descriptive and causal inferences from diagnostic pieces of evidence —often understood as part of a temporal sequence of events or phenomena" (824). This methodology achieves a) to 
describe political and social phenomena, and b) to evaluate causal claims. The longitudinal analysis of resilience in Ecuador has several breaks over time that profoundly influence the trajectories on beach use and governance. These include, on the one hand, neoliberal and anti-neoliberal state practices, and on the other, the 1997-1998 ENSO.

Accordingly, Process Tracing begins by "taking good snapshots at a series of specific moments," then, "observing change or sequence" (Collier 2011, 824). Therefore, I first describe, in a comprehensive manner, coastal management, risk management, and tourism development in Santa Elena. Then, with "a sense of 'static' description" (ibid, 823) of each layer in trajectory, I pay close attention to sequences of independent, dependent, and intervening variables to analyze trajectories of change and causation. In doing so, I express how resilience transverses and morphs in complex milieus.

Despite the geographical insights of my research, my work presents an anthropological account of the interstices of local struggles in Santa Elena. I used to spend my school vacations in the rural parish of Manglaralto, when a dirt road connected the northern parish with the main town of Santa Elena. Pristine landscapes between the river mouth and the wide sandy beaches were well worth the long and tiresome journey there. At the surf zone, the larveros strained their arms to handle large nets in the swinging waves to collect natural shrimp larvae, while fishers arrived at the beach with their pangas or small boats full of fresh fish. After some decades, I started to visit the north of Santa Elena again. From 2008 through 2013, I participated in several projects managed by the Ecuadorian Ministry of Tourism and the Ministry of Public Works and Transportation. The unspoiled beaches had disappeared together with the larveros, while 
a handful of pangas spent more time on the beach than on the sea. Numerous bamboo cabanas stretch out along the beach into the distance while tourists enjoy their leisure time.

I position myself as a native anthropologist to portray the coastal development in Santa Elena. Having born and raised in Guayaquil, the main port of Ecuador, embedded me of the Ecuadorian coastal identity, which emerges amidst the Pacific Ocean, beach landscapes, and estuarine zones. I learned the traditions of rural seaside villages since I was a child when I visited my relatives who lived in Santa Elena, practically every year. I deepened my understanding on Santa Elenians' rural life after performing several fieldworks a decade ago. In the early 2000s, I inventoried natural and cultural tourist attractions for the Ministry of Tourism. I also collected socio-economic data for the Ministry of Transportation and Public Works in several seaside villages of Santa Elena. While working in rural Santa Elena, I realized how far are the rural and urban traditions on the coast of Ecuador. Although the marine and coastal environments strongly influence coastal identity, the regional administration centralized in Guayaquil influenced relationships between Santa Elenians and those who grew up in the city of Guayaquil. The city port has long-lasting centralized administration of the coast. Furthermore, such centralization was one of the main reasons for separating the current Province of Santa Elena from the Province of Guayas in the year 2007. Although my position as a visiting tourist, as a government employee, and then as a visiting scholar distances me from the rural life of comuneros, my long stays in the comunas allows me to understand comuneros engagements with nature and development. 
Nowadays, Santa Elena's coastal landscapes highlight the inequality between development and resources. Initially, I did not understand how those changes arose, what caused them, or the conflicts that have emerged as a result. Through this dissertation, I disentangle the configurations of power among ecosystems, population, and decisionmaking to determine both the winner and loser in the subset of driving forces pressuring Santa Elena's beaches. As a native anthropologist, I have also experienced the consequences of unstable politics in Ecuador which has seen numerous presidential impeachments and resignations over the last decades. However, rather than analyzing conditions of changing governmental practices, I concentrate my efforts on their effects, concurrent with the adoption of global development and security managerial practices. I focus on how governments have managed the coastal environment and natural resources according to the logic of neoliberal and anti-neoliberal governmental practices, paying particular attention to coastal zone governance, where the intertidal connection between the ocean and humans provides ecological, economical, and recreational value. Thus, I sought out governmental rationales and policies ruling coastal zones, and everyday life interactions with the intertidal zone, to hear the petitions of rural individuals and the demands of nature as well.

Additionally, I am speaking from the Ecuadorian coast to open analytical discussions from a local perspective. In doing so, rather than replicating another pervasive Northern approach to underdeveloped societies, I am taking a post-colonial stand of ethical responsibility on the representation (Slater 2004) of Ecuadorian coastal people. My post-colonial approach motivates me to rethink patterns of dominant global (northern) frameworks largely shaping governmental policies in Ecuador. Firstly, they are 
ineffective in the rural realities of the coast. Secondly, they are not limiting rural demands for development and security. According to Slater (2004), northern imaginaries of the rural south depict an immature individual who is unable to assert his reality. Similarly, critical resilience scholars contend that resilience building neglects opportunities for alternative lives. However, comuneros' demands for protection are actually demands for allowing them to create their own realities within contemporary complexities of development and security. Furthermore, despite neoliberal or anti-neoliberal governments, comuneros continue making decisions on - and adapting to - the effects of processes such as the alignment of the moon, the sun, and the earth influences nature, development and security. Thus, the primacy of local processes in Santa Elena challenges global conceptions of risk, security, and development.

During fieldwork, I visited nine coastal communities in Santa Elena: Valdivia, Libertador Bolívar, San Antonio, Olón, Manglaralto, Curía, Cadeate, San José, and La Entrada. I also visited Salango, the southern community in the Province of Manabí, which has historical connections to northern Santa Elena. The research specifically targeted individuals representing different social groups with ongoing roles in risk and coastal management, tourism development processes, and rural life in Santa Elena. I conducted one-on-one formal and semi-formal in-depth interviews with governmental officials including the first Risk Management Secretary (1 person); former (4 people) and current (5) risk management officials; former (5) and current (9) Tourism Ministry officials; Santa Elena's seawalls Designer Engineer (1); Public Works Ministry officials (3); and Executive Managers of NGOs (2). I also conducted formal one-on-one in-depth 
interviews (and many walking interviews on a day-to-day basis) with community leaders in rural villages (8). Appendix 1 shows the IRB approved interview templates I applied.

I also conducted one group interview with the members of the Asociación de Servidores Turísticos "Rio-Mar" or the "River-Sea" Association of Small Tourism Businesses (13 members) and two additional group interviews with leaders of communities (5 people). I also conducted one-on-one, semi-formal interviews with individuals working in the tourism industry, such as hotel and restaurant owners (8); hotel and restaurant staff members (4); paragliding guides (2); handcraft makers and sellers (6); surfing trainers (1); informal sellers on the beach (4); and lifeguards (2). I conducted participant-observation in four rural villages in Manglaralto parish, Province of Santa Elena, but particularly in Libertador Bolívar, a community that keeps their territory free of foreign investors due to their deep attachment to their communal land. In this dissertation, I avoid pseudonyms for high-ranked officials and comuneros leaders. However, in particular quotes I gave codes, such as E1 or E2, to protect their identities, based on what interviewees requested.

The dissertation also presents thick ethnographic accounts of interactions with villagers and leaders. I engaged in participant observation in ordinary events. I accompanied comuneros riot claiming on a seizure of 7.5 hectares of their territory. With my friends Milton and Osvaldo I toured the northern comunas of Manglaralto. I had relaxing times in the hammocks while chatting with the comuneros after a holiday of high tourist demand, and I also experienced the rush of salvaging everything we could while waves destroyed the cabanas on the beach. I attended community assemblies (August 2015, November 2016, June, July, and August 2018), where, in my previous role as 
consultant, I presented governmental projects. Archival research is crucial in my research to connect local decision-making with place-specific contestations on development and security. I capture local episodes by analyzing fifteen years of Libertador Bolívar Community Assemblies' minutes, from the year 2003 to 2018.

I also conducted policy analysis. During fieldwork, government staff facilitated numerous policies and programs regarding risk management and development, Santa Elena's provincial projects, and municipal by laws. I also downloaded official plans, policies, and programs from official websites or requesting them by email to government departments. Additionally, I gathered information from relevant newspapers and social media sites. Most documents (policies, news, community assembly archives) I analyzed throughout my research are written in Spanish. As a native Spanish speaker, I have done all translations myself, except where otherwise noted.

Almost all of my interviews were recorded and transcribed accurately to preserve validity. The transcribed interviews were then coded using NVIVO Software 12.4.0 twice. From a first coding emerged main themes, grounding my theoretical discussion. Then, I elaborated a matrix of codes (Appendix 2), which included concepts, perceptions, and practices of resilience in the coast of Ecuador. Notably, the code matrix established breaks over time to capture local episodes between stronger driving forces that have shaped the history of the comuneros: neoliberal and anti-neoliberal regimes, and the 1997/1998 ENSO. The second coding process also included policies and other official documents such as agendas, plans, and technical reports. In doing so, I captured the claims from slow emergencies and the politics of resilience they entail. 


\section{Overview of the chapters}

Illuminated by Foucauldian analysis of government, in Chapter 2, I theorize on the effects of biopolitics in different fields: social, nature, sovereignty, and alternative possibilities. The first section addresses the governance of the social to emphasize how environmental governmentality spread throughout the world. In doing so, the analysis reveals the urgency of providing nature with a political space in the complex socioecological relationship. Second, I address the biopolitics of resilience to understand the malleability of ubiquitous resilience. I collect initial ecology scholarship that introduced complexity as an approach to human-in-environment research. Then, I shift to the pervasive logic of resilience building and its critique, to unpack a discourse and practice that actually is limiting local alternatives. The third section collects debates on alternatives limited by other governmental politics. Particularly, I address sovereignty as a way to show local decision-making processes embedded in governmental logics. Then, I disclose critical approaches to introduce alternatives into academic discussions. In sum, the literature review aims to capture post-colonial claims on the political.

In Chapter 3, I outline multiple stressors pressuring everyday life on the coast of Ecuador. By stressors, I refer to a) political and judicial fragility in Ecuador; b) seaside villagers' desire for development and progress; and 3) natural processes in a complex coastal physical geography, all of which are dynamically interconnected, shaping and reshaping the socio-ecological landscape. A biopolitical approach suggests that governments structure and shape the field of possible action of subjects (Foucault 2007, Dean 2010). Thus, I trace governments ruling Ecuador for 40 years, illuminating the different rationales that emerged during thirty years of neoliberal state practices and a 
decade of the left-led anti-neoliberal regime. My approach here is far from any critique of economic policies. Instead, I focus on "relations between the ways in which people are governed and the ways in which [people] are advised to govern themselves" (Rose 1996, 340). Having elaborated a national frame, I move down to the local complexity of Santa Elena, drawing upon anthropological (Erazo 2013, Simpson 2008) and geographical (Agnew 1994, Coleman \& Grove 2009) debates on sovereignty to unveil that comuneros continue being self-conscious subjects. They do not solely rely on governmental interventions. Instead, comuneros decide and negotiate their economic development despite the uncertainties with which they coexist. I argue that Santa Elena's rural villagers practice their own resilience; they continuously adapt to new realities. Chapter 3 elaborates on a setting that clarifies two rationales governing Ecuador, crucial for tracing how resilience has traversed Ecuadorians' lives.

Chapters 4 and 5 engage a genealogical analysis of policies, programs, and strategies operating on the coast of Ecuador. Chapter $\mathbf{4}$ traces how the Ecuadorian governments have addressed disaster management to understand the influence of resilience thinking on such programs. Overall, the chapter reveals the evolution of disaster management from response to anticipatory and mitigation logic. Chapter 5 traces a long-lasting coastal management program, which introduced tourist development in Santa Elena. Interestingly, the research reveals that the program was rooted in adaptive governance, a concept developed by resilience ecologists. My goal in both chapters is to 1) disclose global discourse influencing Ecuadorian coastal governance; and 2) capture governmental techniques of security during neoliberal or anti-neoliberal governments. 
Both chapters uncover how resilience has traversed neoliberal and anti-neoliberal contexts by adapting discourses on nature, development, and security.

Chapter 6 delves into the micro-politics of everyday life in Santa Elena. By cataloging the social and environmental changes Santa Elena has gone through, the chapter discloses current struggles, and unpacks the interstices between tourism, risk and coastal management policies, in which comuneros autonomously decide on the use of communal lands and the future development of the comuna. Importantly, this chapter highlights beach ecosystems as a crucial resource for tourism development and discloses the effects of this industry on beach ecology. However, new stressors such as global environmental changes are now influencing the slow emergencies and the claims of rural comuneros that I capture in this chapter.

Chapter 7 collects my reflections on social and ecological changes Santa Elena has undergone in four decades. Drawing upon the previous chapters, I disclose the unintended consequences of governmental policies applying resilience in managing the coast of Ecuador. On the one hand, global discourses of sustainable development strongly shaped neoliberal tourist development in Santa Elena. On the other hand, global anticipatory and mitigation criteria influenced Santa Elena's anti-neoliberal tourist development. However, both governmental rationales have problematized nature to justify intervention while having unintended consequences on beach ecosystems. Finally, no matter what rationale and technologies of security Ecuadorian governments have deployed to rule coastal management, the effects are now on the beach ecosystem as well as on the social system. Chapter $\mathbf{8}$ provides conclusions on my theoretical and practical contributions. 
This dissertation approaches the struggles of rural lives in seaside communities, and the struggles of nature within an open-ended human-in-environment relationship. I only hope that in disentangling socio-ecological indeterminacy, researchers and policymakers can hear both, the claim of nature and the claim of the social in an everchanging world. 


\section{CHAPTER II}

\section{Untangling complex relations among the state, government, population, and nature}

Countering modern dualisms between nature and culture, social science has disclosed an intimate human-in-environment relationship that admits numerous vectors within an open-ended system. Thus, a global socio-cultural study requires the researcher to untangle the ongoing interplay of the vectors within such complex systems. This chapter examines contemporary literature regarding complex relationships among the State, the government, the population, and nature. In doing so, the analysis provides a foundational theory to address interstices emerging from dominant discourses about socio-nature dispositions.

Biopolitcs, a term coined by Michel Foucault (2008), illuminates the discussion about power relations and the multiple mechanisms through which "human species became the object of a political strategy" (Foucault 2007, 16). Foucault discloses how governments create governable subjects through mechanisms of power that have effects on both, the population and the body of individuals (Foucault 2003, 2007; Rabinow \& Rose 2006). Those mechanisms deployed over the population ultimately create a sense of normality (Anderson 2011, Rabinow 2010). Stephen Collier $(2009,3)$ elucidates biopolitics as "the attempt to govern a population's health, welfare, and conditions of existence in the framework of political sovereignty." Thus, a biopolitical analysis unravels hidden strategies and tactics allowed to control social life through government's virtuosity. 
Foucault's biopolitics also opened opportunities for debates on locals' encounters of resistance and alternatives (Foucault 1978, Foucault 1982, Rabinow 2010). This bottom-up approach to power acknowledges the interstices of collective action and individuals' agency despite strategies of normalization or social control. Thus, the analysis of biopolitics also dislocates and compels the idea of a sovereign State having control over people's lives: their will, their future, and their progress. For instance, Jessica Catellino (2006) traces how the US government modernized Seminoles' housing in Florida during the 1960s. The Western logic of development overlooked Seminoles' social meaning behind customary housing and introduced modern housing systems with windows and poor circulation of air, as well as housing technologies, such as ovens and fans. US governmental housing programs caused a total reorganization of Seminoles' kinship, gender, and space.

Interestingly, Catellino (2006) also traces the effects after the Seminole Tribe of Florida started to control the Housing Department in the late 1990s. The tribe promoted traditional and hybrid dwelling structures, such as chickee and thatched-roof houses. More importantly, after policy shifted to permitting construction beyond designated development plots, housing practices have also changed. Several families returned to a more scattered settlement pattern, argues Catellino. Thus, tracing the contemporary history of government-motivated modernization also reveals changes in future social relations with the environment. From the new socio-ecological stability, alternatives ways of living also emerge.

Illuminated by Foucault's biopolitics, three theoretical foundations undergird this dissertation. The first set of literature focuses on the governance of society and nature. 
The analysis reveals the need for providing nature a more important political space. The literature review then shifts towards resilience, a current trend of governmental intervention pursuing societal security. In the third section, the literature review addresses the alternatives that have continued to exist outside of government-induced normality. A brief conclusion sums up the need for dismissing juridical-legal normality and rather highlighting the alternative possibilities emerging from the complex socio-ecological relations.

\section{The biopolitics of socio-nature governance}

The literature in this section addresses contemporary discussions about the complicated social, ecological, and economic relationships the State and the government entail. Under a biopolitical scope, this section focuses on the government's virtuosity and its effects over the population and nature. First, the analysis addresses the governance of the social, then moves to examine the governance of nature. This literature review also examines the entrenchments among capitalism, sustainable development, and nature to show the effects of governmental intervention in contemporary history.

State, government, and the social

A pre-constituted juridical structure within a territorial functioning continues to be a comprehensive understanding of nation-state. However, nation-states (hereafter State) coexist within complexities beyond the juridical-legal relationships among inhabitants and territory. Michel Foucault (2003), in his Lectures at the College of France, identified 
those complexities as "other things." Those "things" relate inhabitants' daily activities with nature, environment, culture, and security; for instance, crop traditions and misfortunes. Drawing upon Foucault, Swyngedouw $(2004,9)$ addresses such complexities as "network of interwoven socio-spatial processes that are simultaneously human, material, natural, discursive, cultural, and organic." Thus, the State "does not exist in the phenomenal world, $[\ldots]$ what does exist is a collection of individual beings connected by a complex system of relations" (Trouillot 2001, 127, quoting RadcliffeBrown 1995[1940]: xxiii). Then, complex systems include "set of practices and processes and their effects" (Trouillot 2001, 131). Thus, processes and effects both profoundly influence socio-ecological relationships. Consequently, the State becomes an abstraction that compresses tangible objects, subjects, and several institutional forms: family, community, society, economy, policy, government, and others.

Moreover, the State assumes the condition of coordinator among those multiple institutions (Sharma and Gupta 2006). Among them, the government reifies the State's abstraction by operating its incessant social, political, and economic transactions (Ferguson \& Lohman 1994). The government mediates the State/society relationships through the state apparatus, which comprises those public and private institutions. Thus, the state apparatus comprises not only state offices, but also offices indirectly serving the State, or those non-statal or para-statal organizations through which the State spreads its power in a multiplicity of social contexts (Ferguson 1994, Trouillot 2001). The increasingly close-fitting roles of State and private agencies hinder any separation of responsibilities within the state apparatus. Indeed, state apparatus is inclusive and broad 
ranging (Whitehead et al. 2007). In doing so, the state apparatus can operate throughout the population.

The population became the subject of government after governance rationales decentered the model of the family. Foucault (2003) reveals how mid-1 $8^{\text {th }}$ century statistics began to show regularities in the population (i.e., rate of deaths and diseases), aggregate effects on the population (epidemics, ascending spirals of labor and wealth), and specific economic effects irreducible to the family. Then, the family became an element internal to population and "population comes to appear above all else as the ultimate end of government" (Foucault 1991, 100). Once the population becomes a collective subject, "mechanisms are directed in order to have a particular effect on [the population]" (Foucault 2007, 43). Thus, the government appears as a "mode of action on actions" or "the conduct of conduct" (Foucault, 2007), which ultimately shapes the conduct of humans by direct or indirect means.

Foucault (2007) focuses on the government's indirect forms of intervention, which appear "with the function of modifying something in the biological destiny of the species" (10). One of the examples Foucault analyzes is the epidemic and inoculation campaign in the eighteenth century. Through such campaigns, the government satisfies the population's health demands. Foucault additionally highlights, "[the population] is both aware of what it wants and unaware of what is being done to it" $(2007,105)$. Thus, the government achieves care for the population through conducting them and controlling social life.

Thus, government operates over subjects' conduct "entailing new relations between the ways in which people are governed by others and the ways in which they are 
advised to govern themselves," argues Nikolas Rose (1996a, 340). In a similar vein, Mitchell Dean $(2010,20)$ argues that government "entails an attempt to affect and shape in some way who and what individuals and collectives are and should be." Consequently, concludes Dean $(2010,200)$ "government is crucially concerned to modify a certain space marked out by entities such as the individual, its selfhood or personage, or the personality character, capacities, levels of self-esteem and motivation the individual possesses." Hence, government pervades the population to achieve social control. In doing so, the government comprises "a whole series of specific governmental apparatuses" (techniques and tactics) and "complex of saviors," that include knowledge and discourses (Foucault 2007). Firstly, mechanisms in motion throughout the state apparatus are easily identifiable as a legal and disciplinary mechanism. However, Foucault (2007) highlights the mechanisms of social control which respond to reality by regulating that reality. Thus, the law works in the imaginary by imagining the negative to be prevented. In a complementary sphere working over individuals, discipline faces the nature of reality. Contemporary "mechanisms of security" make the components of reality work with each other through calculations and specific arrangements. Foucault clarifies, "there is not a succession of law, then discipline, then security" $(2007,25)$. They all operate to normalize and control social life.

According to Davoudi and Madanipour (2015), regulatory mechanisms of security encompass the "bundle of strategies, techniques, procedures, mechanisms, and practices through which authorities seek to make government programmes operable" (81). Furthermore, those mechanisms of security are disguised through and assembled into the apparatus of the State (Sharma \& Gupta 2006). Furthermore, mechanisms of security 
increase the government's capacity to manage the population while responding to governments' concern on how to foster life (Foucault 1978). Thus, the government needs to create the necessary conditions of possibility to secure the population. In doing so, governments create complex "saviors" and a set of mechanisms, relations, and procedures that "normalize" the population (Foucault 2008, 2007). Those "politics of truth" become an imperative discourse highlighting what government dictates as normal and abnormal (Foucault 2007). Thus, the government's normal emerges as a reality within social life.

Such reality is not a natural phenomenon; it emerges from the organization of knowledge responding to specific rationality (Said 1978). Furthermore, the politics of truth configure an "imagined territory" upon which the government and its politics should act, argues Dillon (1995). For Nikolas Rose (1996a, 331), those "new political languages are embodied in the ways in which a whole series of issues are problematized - made amenable to authoritative action in terms of features of communities and their strengths, cultures, pathologies." Consequently, the population "is now something to be programmed" (Rose 1996a, 332), by discourses, programs, and policies.

Relevant here is Mahmood's (2005) argument that central to the formulation on social control is what Foucault "calls the paradox of subjectivation: the very processes and conditions that secure a subject's subordination are also the means by which she becomes a self-conscious identity and agent" (17). It turns upside-down the idea of individuals' agency. Paradoxically, argues Mahmood, individuals' agency is not merely "a synonym for resistance to relations of domination, but as a capacity for action that specific relations of subordination create and enable" (2007, 18 original emphasis). In a similar vein, Tania Murray Li (2007) argues how many governmental schemes appear as 
the natural expression of every day. Mahmood and Li critique the government's virtuosity to control social life.

Since its origin, the State must achieve an adequate disposition of the social, biological, and economic life of the population. That is what Foucault (2007) calls "the art of governing." However, Foucault's analysis of governmental practices reveals that the best possible way of governing responds to a "reasoned way of governing best" (Foucault, 2008:2). Consequently, according to Foucault (2007), the political rationale guiding a government determines socio-economic-nature arrangements. Foucault coined the term governmentality to refer to how governments assemble "institutions, procedures, analyses and reflections, calculations, and tactics" that "has the population as its target, political economy as its major form of knowledge, and apparatuses of security as its essential technical instruments" $(2007,108)$. However, according to Dillon (1995), the power of governmentality resides in being a domain of cognition rather than legislation. Moreover, the art of governing "does not merely make use of knowledge; it is comprised by knowledge" (Dillon 1995, 330). Therefore, governmentality intensely depends upon experts and institutions of knowledge devoted to "the calculated administration of diverse aspects of conduct" through "education, persuasion, inducement, management, incitement, motivation and encouragement" (Dillon 1995, 330).

Nikolas Rose's (1996a) arguments clarify the present discussion about Foucault's governmentality and its relation to the creation of knowledge. Nicolas Rose understands governmentality as "the deliberations, strategies, tactics, and devices employed by authorities for making up and acting upon a population and its constituents to ensure good and avert ill" (1996a:328). This notion highlights the focus on the goals, intentions, 
or interests of the authorities operating within a territory. Consequently, Rose proposes to analyze governmentality according to the political rationality or governmental reasoning, through which the state apparatus deploys mechanisms over the population (Rose 1996b). To emphasize his analysis, Rose highlights two sections in the word governmentality. The first - govern - referring to the ensemble of processes, and the second - mentality denoting the way the government thinks. Rose argues that, although both the State and the population pursue wellbeing as their primary goal, the government carries an "idealized schemata" on how to achieve that purpose (Rose 1996b, 42). In order to create the most favorable relation among inhabitants, nature, culture, and security, the government also creates "intellectual machinery," which "render[s] reality thinkable and amenable to political programming" (ibid). Thus, a governmental authoritative criterion "regulate[s] decisions and actions of individuals, groups, and organizations" (Rose 1996b, 42) by creating a series of knowledge and discourses, the "politics of truths." In sum, Foucault's governmentality opened contemporary examinations of the effects of the ruling, governing, normalizing, regulating, and controlling social life through the creation of mechanisms that make the population amenable to authoritative criteria. The virtuosity of government resides in its art of controlling social life by problematizing social phenomena through techniques and tactics of knowledge which, ultimately, makes individuals unaware of their subjectivization. In the next section, the literature review addresses the analysis of environmental governmentality, the way governments approach and manage nature. 


\section{Environmental governmentality}

The above section reviews how governments arrange social relations according to their rationale. In light of this, the following paragraphs review discussions on the construction of nature, the deep engagement of governments acting over nature, and the politics of nature. Nowadays, it is not usual to enjoy pristine landscapes; instead, nature emerges as a product of culture. Indeed, scholarship has extensively shown that nature is the product of human intervention. For instance, Stephen Lansing (1991) shows how religious beliefs and a desire to live peacefully among many villages led to a system that distributed water equitably, kept insect populations low, and fed many people living over a large area. The Bali case shows the complex cultural intervention over nature. Science has been another form of intervening nature since science translates nature into knowledge. For instance, Bruno Latour (1999) describes how experts collect, categorize and transfer the Amazonian forest-savanna in Brazil into expert knowledge.

Governments also intervene in nature. For instance, Jeffrey Sasha Davis (2005) traces the transition of the Bikini Atoll from a site of nuclear tests and radioactive waste to a tourists' paradise for divers. In his analysis, Davis discloses the production and reproduction of nature led by the US government and, later, by the Bikini Government. The logic of both governments prevailed over the island's nature and shaped individuals' conceptualization of nature. The logic of the government also shapes human relations with nature. For instance, Agrawal (2005) traces numerous environmental practices and perceptions adopted by the Kumaonis in northern India after implementing forest councils. The Indian Forest and Revenue Departments supervised forest councils through a robust technical bureaucracy, while government assembled regulatory legal frameworks 
towards forest conservation. Ultimately, Agrawal reveals that Kumaonis became "environmental subjects," concerned for the environment and its conservation according to governmental discourses.

According to James Scott (1998), the logic of the State focuses on nature's utilitarian value, the fiscal and commercial value derived from an ecological habitat, such as forest and plants. Thus, forest and plants become "natural resources" - the forest becomes wood, while plants become crops. After the notion of "natural resources" replaced the term nature, it thus "can be appropriated for human use" (Scott 1998, 13). Scott additionally examines governmental formulas of simplification of nature in forms of knowledge (using maps, cadastral surveys, land-records), which ultimately makes it possible to control and manipulate the forest.

States often see nature as merely a source of wealth, contributing to a capitalist system of production which approaches nature as a commodity, a means of production through labor (Escobar 1995). Capitalism has transformed forest ecosystems into monocultural landscapes (Gudynas 2010), mangroves into industrial shrimp farms (Pazmiño et al. 2018, Arriaga 2000), pristine beaches into modern resorts (Padilla 2015). Since colonial encounters, such transformation of nature accompanies global trading and political economy. Thus, nature has become a natural resource serving to provision the population's wellbeing. As a result, degradation of natural resources became a new social phenomenon in the lands occupied by rural peasants and Indigenous peoples.

Under the label of Sustainable Development, a worldwide environmentally sensitive view emerged in response to the capitalist transformation of nature (Adams 2009, Gudynas 2011). The focus here is the acknowledgment of the biopolitical 
articulation of Sustainable Development (SD). Since the early 1970s, UN efforts to address conflicts between environment and development have spread throughout the world through the notion of SD. Notably, after the 1987 Brundtland Commission's report "Our Common Future," followed by the Agenda 21 at the Rio Conference in 1992, countries have adopted SD criteria as a poverty panacea. Since 2005, 17 Goals of Sustainable Development, issued from a global dialogue mediated in the UN, are a reference foundation for social and environmental planned intervention (Cano et al. 2019). Certainly, SD is reformist, argues Adams (2009). Thus, governments, politicians, and development bureaucrats have enthusiastically incorporated SD programs and plans worldwide, while the literature shows SD locating human beings and nature as the object of a political strategy. Thus, SD became a contemporary "mechanism of security," which requires the components of reality to work through a series of expert knowledge and specific arrangements. In addition to a planned organization at the local level, SD practices also include the impulse of social institutions (Cano et a. 2019) and social movements (Kates et al. 2005). In broadening SD actions from ecocentric to anthropocentric initiatives, an intricate link between environment, development, and poverty emerged, argues Adams (2009). Thus, the concept SD "maintains a creative tension between a few core principles and an openness to reinterpretation and adaptation to different social and ecological contexts" (Kates et al. 2005). It is therefore a key locus for the analysis of environmental governmentality.

Luke (2006) traces a parallel between Foucault's biopolitics and international efforts of managing nature. Luke instantiates his argument analyzing the Worldwatch Institute, an international environmental movement that continually attempts to reinvent 
the forces of nature into economic terms and managerial procedures. In doing so, Luke argues that international environmental management aims "the right disposition of things" (263, quoting Foucault 1991, 93). Consequently, environmentality "would govern by restructuring today's ecologically unsound society through elaborate managerial designs to realize tomorrow's environmental-sustainable economy" (Luke 2006, 266). Thus, international institutions concerned about environmental management create ecoknowledge in the form of specific bioeconomic terms of nature. Additionally, environmentality disciplines sustainability through discourses that signal "who-can" and "how-to" manage nature (Luke 2006, 267). Thus, environmentality has become a practice that challenges State borders while imposing international forms to construct sustainable environments.

Similarly, Tanya Murray Li (2007) discloses the biopolitics of environmental governance through the analysis of the Indonesian governments. Li argues that Indonesian governments' "will to improve" required: 1) the problematization of deficiencies that need to be rectified, and 2) the practice of "rendering technical," that is to say, making governance an intelligible field of experts. Interestingly, $\mathrm{Li}$ traces how the Sulawesi highlands became privatized and commodified, mainly through the introduction of cacao crops, but also due to international conservationist goals in conflictive zones within the Lore Lindu National Park. In doing so, Li not only addresses the governmental rationalities arranging the socio-ecological and economic relationships in Indonesia, but also highlights the political conflicts within the socio-ecological relationship and governmental arrangements. 
In a similar vein, Whitehead et al. (2007) focus on how States frame nature through governmental techniques, particularly territorialization and centralization. Territorialization constructs boundaries that facilitate regulation of nature, while centralization refers to the creation of knowledge regarding nature. In doing so, Whitehead et al. argue that the State provides a political context for constructing nature. In the state/nature relation, nature appears as a knowable and controllable object, a national resource that benefits the whole population, and a geopolitical target of modern states. Thus, Whitehead et al. reveal nature as "an object of political struggle" $(2007,7)$, among contemporary States.

The environmental governmentality discussed by Luke, Li, and Whitehead et al., moves nature from mere ecological existence to a political sphere. Relevant here is the work of Marisol de la Cadena (2010), who argues that politics have denied nature. De La Cadena asserts, "earth-beings" are now "more public than ever" $(2010,352)$. By "earthbeings," she refers to mountains, forest, fish, landscape, and all other-than-human beings. They are "sentient entities" with material existence, argues De La Cadena. The reason for the problematic understanding of earth-beings' participation in politics comes from the disjunction between science and politics about nonhumans' participation in politics. De La Cadena argues that nature needs translators and proposes the visibility of earthbeings by a reconfiguration of the political.

In this sense, Australia, New Zealand, and India have recently provided legal rights to the rivers (O’Donnell and Talbot-Jones 2018). Ecuador has concreted the most crucial innovation in environmental policies, recognizing rights to nature in the 2008 Constitution (Gudynas 2016). Bolivia followed such recognition in 2009. However, 
Gudynas $(2010,2016)$ stated that Ecuadorian and Bolivian governments have continued relying on the country's economy based on extractive industries, which profoundly affect the population and the environment.

Thus, the work of Arturo Escobar (1999) disclosing an antiessentialist political ecology must remain active in current analyses of nature's transformations. Escobar defines three regimes of nature: organic, capitalist, and techno-nature. The organic nature articulates local forms of transformation, distant from dominant modern capitalist nature, which is uniform, legible, and manageable. The capitalist appropriation of nature, on the other hand, led to environmental degradation. Then, discourses of ecological sustainability, biodiversity, and conservationism emerged within the capitalist nature. Techno-nature, Escobar's third form of nature articulation, creates radical biological alterity of nature and causes alterity to proliferate; for instance, biotechnology, which is believed to have universal application. Clearly, the organic, capitalist, and techno regimes of nature historically "co-exist and overlap" (Escobar 1999, 5). Thus, Escobar argues, political ecology should historically examine the mutual articulations and contradictions of regimes of nature since "nature has ceased to be essentially anything for most people, including [...] those attached to organic natures" (Escobar 1999, 15). Escobar favors raising questions on nature within the historical constitution of subjectivity since nature can be seen as regimes of discursive articulations and is differently experienced and produced. Thus, the analysis of environmental governmentality should reveal the biopolitics of socio-nature relationships by addressing the always open and incomplete contradictions between the plurality of natures' creation and intervention. 


\section{Biopolitics of resilience}

Resilience has become a new governmental practice that aims to reorganize socioenvironmental relations, particularly responding to increasing natural or anthropogenic threats. Indeed, following global frameworks, worldwide national governments and cities have adopted organizing socio-ecological relations under the concept of prevention. This section analyzes how resilience has reached ubiquity in the global scene. The first section addresses the resilience path from ecology to the social sciences and reaching its institutionalization through governmental policies and programs. Then, the discussion analyzes the current critiques of resilience-driven initiatives.

\section{The path of resilience}

The ubiquitous term resilience has a long journey in academia and policymaking. Complexity is a pillar to understand resilience. However, complexity has been approached in different fields. Anthropology has addressed complexity particularly after Roy A. Rappaport discussed the notion of equilibrium-based systems including the ecological, the social, and the cultural components, in the late 1960s. In his book Pigs for the Ancestors (1967), Rappaport approaches the Tsembaga people of New Guinea as "an ecological population in an ecosystem that also includes the other living populations and the nonliving substances found within the boundaries of Tsembaga territory" $(1967,6)$. In resilience words: as a socio-ecological system. Human and ecosystem relation was a fascinating idea, particularly, in a time of an "ingrained habit of seeing the inorganic, organic, and sociocultural as separate realms or levels of phenomena" (1967, xiii). These 
interrelations, according to Rappaport, imply a system with variables that change and, hence, emergent outcomes toward survival appear.

Furthermore, Rappaport asserts that human-environment systems have the virtue of self-regulation. Mechanisms of systemic relationships and internal processes allow the system, the Tsembaga people, to survive, concludes Rappaport. Later, Elliot Fratkin's (1986) work in a pastoralist community in Kenya focuses on stability and resilience in biological populations. Motivated by the novel approach introduced by Holling, Fratkin calls for introducing these concepts in the analysis of social adaptations and reinforcing the ideas of complexity in anthropological work.

Indeed, the idea of complexity continued among anthropologists — for instance, Stephen Lansing (1991) shows how Indigenous Balinese people managed the timing of stream-fed irrigation of rice terraces in such a way as to sustain many farmer's access to water while avoiding pests, while the externally-imposed technical solutions introduced by the Dutch government failed. By going back and forth between the ecological systems, the social system, and the cultural system, Lansing aimed to reveal how Indigenous expertise can generate adaptive non-linear networks. Furthermore, processes of self-organization construct and will continue constructing the rice terraces (a humanized nature). Thus, Lansing provides an anthropological analysis of humanenvironmental complexity.

Within the field of Ecology, from which the analysis of resilience emerged, complexity contributed to linking biological and physical interactions between ecosystems. In his foundational article published in 1973, C. S. Holling addresses ecosystems' persistence, change and unpredictability approaching resilience, a concept 
largely accepted in materials and physics. In engineering, the term describes the capacity of a material to recover its initial state in response to any disturbance and before losing its own properties. Holling (1973) argues that the engineering description of resilience works perfectly in closed systems, where constancy and predictability are the primary responses. However, ecosystems behave differently, mainly due to ecological complexity. An ecological system involves biotic and abiotic elements dynamically interacting and shaping its components. Holling demonstrates that the dynamic integration of complex systems does not respond as predictably as in closed systems.

Holling (1996) also reveals that ecosystems 1) can absorb or buffer any perturbation; 2) can return to a previous state after a disturbance, what Holling calls engineering resilience; and 3) can also adapt their components to new and different stabilities. Thus, ecological resilience (ibid) allows the ecosystem to change variables and processes that control its behavior before the system reconfigures its structure to adapt to other stabilities (Berkes et al. 2003, Folke et al. 2010). The buffering function of the ecosystem reveals a self-regulatory mechanism that can constrain and modify the structure of the system for maintenance and survival (Folke and Berkes 1992). Consequently, resilience in complex systems refers to both the degree of disturbance the system can experience without changing its functioning and the degree of selforganization. The latter endows complex systems with the capacity to adapt by learning (Felicitti 2016).

Fascinated by the socio-ecological complexity and its adaptive capacity, a large group of resilience ecologists documented non-Western ecological management and techniques. Cases from South India, the Andes, Western Himalaya, Java, the Peruvian 
Amazon, and the Solomon Islands among others, reveal humans as another element influencing and influenced by the ecological system (Berkes et al. 1995, Gadgil et al. 1993, Berkes et al. 1996, Folke 2006, Folke 2016). The resilience ecologists' works show that the ecological and the social both function in a constant co-evolution. Consequently, according to ecological resilience, the delineation between the social and ecological systems is artificial and arbitrary (Berkes and Folke 1994). Thus, the notion of socioecological systems as complex interconnections of human-environment systems breaks from modern understandings of nature/society dualism (Kueffer 2015, Folke et al. 2007). Moreover, it is no longer possible to conceive humanity as separated from, above, or controlling nature (Grove \& Chandler 2017). The complexity of SES entails the ecological and the social systems consistently maintaining synergic relations among them.

However, as an open-ended system, SES dynamically integrates new subsystems (or layers). Thus, the ecological system involves biotic and abiotic factors, while the social system includes human beings and a range of social institutions such as livelihoods, economies, and networks (Berkes \& Ross 2012). Elinor Ostrom developed an SES multilevel framework that comprises more than fifty potential interrelated layers (Ostrom 2009, Cumming et al. 2015), including institutions, governmental apparatuses, the market, and others. The multilayered subsystems, also known as driving forces (Folke et al. 2007), act as stressors or attractors of disturbances (Berkes \& Folke 1994, Berkes et al. 2003). Thus, layers or driving forces increase SES' complexity since each of them can disrupt socio-ecological stability. 
Consequently, the multilayered complexity makes the SES inherently unpredictable. Firstly, disruptions include natural events, such as hurricanes, droughts, and severe rainfall. Additional factors disrupting SES could be economic, social, and political conditions such as commodity booms, infrastructure development, colonization systems, and the like. They are noticeable, sudden, and acute events. Secondly, Davoudi (2012) highlights the importance of chronic and quotidian driving forces. They are unnoticeable internal processes that can also change the "very nature of systems" (Davoudi 2012, 302). Thus, external or internal disturbances can produce manifold nonlinear responses. One of the most accepted responses emphasizes that SESs "are able to adapt themselves to internal and external disturbances" (Ostrom \& Janssen 2004, 247). However, Davoudi et al. (2013) argue that nonlinear interactions make the SES inherently unpredictable.

Indeed, SES can produce a disproportionate effect more substantial than the size of perturbation, argues Davoudi et al. (2013). SES can buffer the magnitude of disturbances returning to pre-existing stability (engineering resilience) or can adjust the system to new stabilities (ecological resilience). Both engineering resilience and ecological resilience are features inherited from the ecological system to recover "what it was" and conserving "what it has" (Folke et al. 2010, 25). However, Davoudi et al. $(2013,302)$ realized, "once faced with adversity, [SES] hardly ever return to where [they] were." SES not only can adapt to internal and external disruptions, they can also cross critical thresholds to different new equilibriums to survive.

Consequently, the adaptive capacity of an SES "offers an evolutionary understanding of resilience as continually altering" (Davoudi et al. 2013, 310) the system. 
That socio-ecological resilience (Berkes et al. 2003) or evolutionary resilience (Davoudi et al. 2013) entails the system's transformation while it goes through adaptive cycles (Walker et al. 2004).

The Adaptive Cycle Model developed by Holling (2001), clarifies SES' adaptive and evolutionary capacities and facilitates the understanding of SES adaptive transformation. The model - also known as the Renewal Model, includes the natural, the social, and the socio-ecological systems linked as "a fundamental unit" (Holling 2001, 393). The model also includes cyclic and seasonal cycles represented in reclining figure eights (Berkes et al. 2003) or the form of infinity curves (Davoudi et al. 2013). The transformational model shows phases in which the complex adaptive system (CAS) grows, declines, and is renewed again and again (Holling 2001, Davoudi 2012, Davoudi 2016, Berkes et al. 2003). Relevant here is that each renewal cycle results in unexpected outcomes, thus opening opportunities for new directions, new stabilities.

The CAS model involves four phases. One of two front loops is known as growth or exploitation, and the other one is known as conservation or accumulation. Both front loops move forward through slowly changing situations, furthering the potentiality of the system. Paradoxically, while the complex system itself boosts subsystems' potentiality during exploitation and conservation phases, stressors can reduce the degree of connectedness among controlling variables of the system (Holling 2001).

Consequently, over time, the system loses resilience and becomes more vulnerable. The CAS model embraces sequentiality of two opposites: growth and stability, and change and variety, argues Holling. Thus, after exceeding the limits, the system moves into two different back loops, known as a release or creative destruction 
and re-organization or renewal. Back loops are inventive, innately unpredictable, fertile, uncertain, and increase the resilience of the system (Holling 2001, 2004). While the front loops maximize "production and accumulation," the back loops maximize "invention and reassortment" (Holling 2001, 395).

The CAS model sketches the SES dynamic; however, complexity entails openended systems. The Panarchy cycle developed by Holling and Gunderson (Holling 2001) has the virtue of hierarchically sketching the adaptive cycles nested in more extensive subsystems. In doing so, the Panarchy cycle facilitates pinpointing temporalities, disruptions, and changes that are boosting the system's evolution. This heuristic model of adaptive cycles nested in one another clarifies scalar dynamics of complex systems. It can enlarge dynamics from any particular ecosystem to the biosphere: from cells to ecosystems, to societies, to cultures (Holling 2001).

While CAS became a way to understand human-environment systems, resilience became a way to deal with complexity and the uncertainty it brings (Berkes et al. 2003). In stark contrast to stability and predictability, resilience embraces multiple-equilibriums, and the unpredictability of thresholds within the adaptive cycles (Berkes et al. 2003, Berkes 2010). In addition, Davoudi et al. (2013), highlight that CAS adaptive phases "are not necessarily sequential or fixed [;] some systems can skip a phase and move from the growth phase to release or reorganization phase" (304). An adaptive cycle does not exclusively have straightforward steps: growth, conservation, release, and renewal, neither does a growth cycle follow a renewal cycle. Thus, Davoudi et al. highlight the importance of back loops within the uncertainty of SES' behavior, something missed in deterministic perspectives. 
Observing Holling's model in light of deterministic perspectives, it definitely will return to the growth cycle, that is to say, to the initial state (growth after renewal). Such an approach neglects the transformative characteristic of complex systems which can take unknown directions when reaching the threshold of a renewal cycle. The reorganizational or renewal cycle becomes a tipping point for new and diverse stabilities. Contingent outcomes signal further directions to the following growth cycle consequently, the evolving nature of CAS nests adaptive cycles that change or evolve in time and space. This approach counters Western environmental management rooted in command-control rationale. Conventional ecological management aims to predict and control uncertainties. Thus, methods of ecological management incorporate statistical models to predict possible future scenarios. In doing so, managers can maintain productive resources (but not precisely sustainable). However, socio-ecological uncertainty is increasingly less sensitive to modern assumptions of prediction.

Resilience ecologists' interest in SES' adaptive behavior converged with a critique of conventional resource governance of the 1990s. For instance, Olsson et al. (2004), through examples from Western Sweden and Canada, showed that governments can no longer rely on external interventions that are "legislated top-down," instead, the state requires an intervention "that self-organizes bottom-up" (83). The critique mostly highlighted those distant technicians who, ignorant of local conditions and overlooking human-environment complexity, designed environmental programs. Ostrom (2008, 2829) argues, "instead of presuming that one can design an optimal system in advance and then make it work, we must think about ways to analyze the structure of common-pool resources, how these change over time, and adopt a multi-level experimental approach 
rather than a top-down approach to the design of effective institutions." After acknowledging human-environment complexity, resource management should diagnose and monitor the multiple processes occurring in nested SES, claims Ostrom (Ostrom et al. 2007, Ostrom 2008). In this sense, the back loops of the adaptive cycle should inform environmental managers to design policies according to local realities.

Environmental management will then focus on what it can learn from an ecosystem's collapse to enhance its adaptability rather than centering on growth and conservation, as classical management used to do. Therefore, environmental management processes can be adaptively improved (Berkes et al. 2003). In addition to monitoring back loops and enhancing self-organization, several case studies also revealed the need for participatory processes in adaptive forms of governance (Dietz et al. 2003). For instance, Hughes et al. 2005, analyzing the resilience of marine ecosystems, argue that coral reefs can successfully detect and react to pressures by traditional forms of resource managing. However, once the market integrates the SES, it requires institutional frameworks interacting across multiple scales to balance and reinforce the socialecological systems and the environmental stewardship. Similarly, Brown (2003), analyzing discrepancies between conservation and development programs in the Royal Bardia National Park in Nepal, advocates for adopting adaptive co-management procedures with inclusive decision-making processes, particularly in developing countries and poor regions. Thus, resilience ecologists also incorporated the role of social institutions, organizations, networks, and agency into environmental management (Folke 2016), contrary to top-down management designs. 
Under this light, resilience scholars started to advocate for and promote Adaptive Governance in resource management (Folke and Hahn 2005, Folke 2006, Folke 2016). According to Folke (2006) adaptive governance involves "at least four essential parts: 1) understanding ecosystem dynamics; 2) developing management practices that combine different ecological knowledge systems to interpret and respond to ecosystem feedback and continuously learn; 3) building adaptive capacity to deal with uncertainty and surprise, including external drivers; and 4) supporting flexible institutions and social networks in multi-level governance systems" (262). According to Berkes et al. (2003) ecosystem governance should "mobilize society to (a) couple higher-scale governance institutions with local ecological feedback, and (b) renew or create local self-governance responsive to ecological resilience" (302). Therefore, rather than manage subjects from a distance using formulas; government should grant locals managerial independence by transferring power to local decision-makers within a circumscribed scope of a local authority, suggest Olsson et al. (2004). That is to say, in environmental governance, social systems should be able to enhance their capacities to resist disturbances, be flexible to adapt, and be innovative to transform. Thus, adaptive governance perceives the social system as active agents. This critical contribution of resilience ecologists, which puts the agency on individuals, paves the path to translate resilience from the field of ecology into broader environmental fields.

Post 9/11, global insecurities promoted resilience building in human security discourses and policies (Chandler 2012, Mulligan et al. 2016). Particularly in disaster management, the UN 2005 Hyogo Framework for Action formally institutionalized resilience thinking worldwide. This framework is a policy goal for the international 
disaster management community designed to increase communities' responses to disasters, their adaptive capacities to overcome a disaster, and mitigation (Grove 2013a). By promoting community participation, this strategy reinforces the social system's agency and emphasizes people's voluntary participation and responsibility in disaster risk reduction (Larsen et al. 2011). Davoudi et al. (2013) add to those characteristics of disaster management the need for improving the learning capacity for being prepared. Consequently, prevention and mitigation became a hallmark in resilience policies for disaster management.

In sum, resilience involves complexity and non-linearity. Complex systems are open-ended subsets of systems dynamically interconnected. Subsets may include local, national, and global stressors within the socio-ecological system. This dynamic makes them always navigate through front loops and back loops, aiming to maintain a resilience/vulnerability balance. Self-organization is a central feature to moving forward and backward within the adaptive cycle. Ultimately, the complex system gets in the renewal cycle in order to subsist, persist, and survive. When the system returns to the renewal cycle, it is a tipping point that can bring disproportionate responses, unintended outcomes, or radical possibilities. The system can return to the initial state, but, more importantly, the system can also start a different or alternative stability. Consequently, not only can the system persist, it can adapt, and also transform.

Furthermore, resilience acknowledges the potential of the social component to improve (or constrain) responses of the whole socio-ecological system. Consequently, agency and learning capacity become key mechanism to build more resilient and less vulnerable individuals and communities. Advantageously, the mechanism to build 
resilience can be translated to communities, regions, and globally by national policies and international frameworks. Is resilience-building another panacea for environmental and societal security? The next subsection discloses resilience-building effects over individuals and communities.

\section{A biopolitical critique of resilience-building}

Scholars, concerned with the increasing attention given to resilience in academia and policymaking, have disclosed power relations and hidden constraints in resilience building. This section analyzes critical contributions, showing that the desire of resilience thinking to building more resilient communities subjectivizes individuals through Foucault's mechanisms of security. Thus, resilience-building creates pieces of knowledge regarding threats that justify governmental intervention, while the promotion of a preventive logic locates security responsibility on the population and individuals.

The UK policy under Prime Minister David Cameron, discussed by Chandler \& Reid (2016), instantiates how resilience discourse about societal security works as a mechanism of power. Policy discourse reinforces a preconception about individuals' lack of capability to make the right choices to cope with unexpected events and complexities. This premise locates the moral obligation to enhance their citizens' free choice-making in the almighty governance. In doing so, life, people, and populations become the subject of governance.

Dunn et al.'s (2015) work reveals a resilient subject in constant need of government interventions. Since a catastrophic event splits into past and future, Dunn and others argue resilience practices can refer to overcoming a past event or to being prepared 
for potential future disruption, and that both the past and the imagined future event determine the present. In the present, people need to cope with or to be prepared for new circumstances. While self-organizing capacities allow people to cope with change, being prepared for new situations requires adaptive governance. Government intervention is critical in the analysis of Dunn and colleagues. Governments building resilience promote citizens' active participation and initiatives. In doing so, governments create a desirable resilient subject prepared to deal with change. Paradoxically, this desirable subject becomes a subject in constant need of state intervention. Dunn et al. discloses the effects of improving self-organization capabilities. Governmental intervention actually depoliticized and reduced any "emancipatory potential," creating and reproducing vulnerable individuals who merely are "playthings" of governance, argue Dunn et al. $(2015,7)$. In a similar vein, the Dutch risk management policy discussed by Frerks et al. (2011) also reveals how building resilience ultimately victimizes, disempowers, and creates external dependency.

Grove (2014a) unpacks resilience as a mechanism of security that "immuniz[es] communities against their own excess of adaptive management" (242). Grove centers his attention on the techniques of resilience "de-potentializing socio-ecological life" (242). Firstly, education and training disconnect past and present experiences from local knowledge, recoding them through Western categories. Then, education and training "attempt to deterritorialize local knowledge of hazards and re-territorialize it within the global disaster management assemblages" (Grove 2014a, 246). Additionally, both techniques ascribe environment "as a source of everyday danger," in stark contrast with nature stewardship (ibid). In another article, Grove (2013a) analyzes another technique of 
security frequently applied in resilience-building strategies: planning. During an emergency, when social order, law, and norms are absent, disaster management plans surpass "the sovereign law or social norms" (575). Education, training, and planning require participatory or community-based work partnering with governmental agency staff.

Paradoxically, the deployment of techniques to increase locals' capacity to prevent disasters produces a new experience of the self, while it regulates the relationship with the other (Grove and Adey 2015). Eventually, those techniques limit the population's constituent power to build their particular forms of life (Grove \& Chandler 2017). Consequently, while improving communities' resilience to confront disturbances, resilience building is also reducing possibilities of locals' own agency and the systems' capacity for "becoming-otherwise" (Grove \& Chandler 2017, 85). Thus, when the system reaches the tipping point of renewal -through a catastrophe or a sudden perturbation then, resilience-building limits possibilities of contingency since trained communities will respond according to resilience programs.

In a similar vein, Chandler (2013) posits that resilience discourses and practices increase dependency on external protectors while reducing local opportunities. Particularly in human security, "the more we inculcate these ethical reflexivities, called upon by resilience approaches of relational and associational embeddedness, the less we can separate ourselves as subjects capable of acting politically or ethically in the world" argues Chandler (191). Furthermore, this new form of policy intervention called resilience thinking has become a post-interventionist mechanism since resilience policies do not undermine states' sovereignty. Instead, governments support this post- 
interventionism in the name of building more resilient communities and individuals. Chandler (2012) suggests that post-interventionist capacity has enabled the re-articulation of the dominant agendas of Western intervention.

Thus, a hidden effect of resilience building is the creation of a resilient-minded subject, or the desirable resilient subject mentioned above. According to Evans \& Reid (2015), the resilient-minded subject is a subject permanently struggling to accommodate itself in the actual world. Why does the subject struggle while encompassing resilience policies? In contradiction to resilience-building efforts to create resilient subjects, individuals are not passive, instead they are active. However, while government programs improve resilience, the subject "does not seek to resist change," rather, the individual facilitates "self-knowledge, self-growth, and self-transformation" (Chandler and Reid 2016, 14). According to Foucault, a technology on the individual situates the constitution of thought as a field of subjectivity (1997) and normalization (2007). Thus, individuals respond to what has been created as normal. In an age of catastrophe, such as the one we are living in globally, resilience-building becomes a new mode of subjectivity, while the resilient minded individual seeks to bounce back to the "normal" conditions (or conditions prior to the disruption). Thus, resilience building neglects the non-linearity of complex systems and the attendant alternative possibilities.

Techniques deployed through resilience programs reinforce reliance on individuals' own powers and resources; consequently, the moral responsibility to confront disaster relies on the self-reliant individual. This engineering resilience, argues Davoudi (2016), involves the return to a status quo framed in liberal and neoliberal statecitizenship relations (individualism, privatization, free market). By doing so, resilience 
negates the reorganizational capacity and the creativity of SES's back loops. Then, resilience is negating individuals' transformative opportunities.

The biopolitical analysis reveals resilience as a set of discursive practices governing through societal security (Chandler and Reid 2016) or constructing ways of thinking based on disaster prevention and mitigation (Grove 2013a, 2013b). In addition, resilience has become, more often than not, a mechanism of power despite the intention to empower people to confront adversity. Firstly, resilience-building reduces particular capacities and knowledge - of people, communities, societies, cultures - to adapt to changes and risks. Secondly, resilience-building changes and neglects transformational opportunities that may emerge from socio-ecological systems' intelligence. Thirdly, resilience-building produces a series of truths and systems of knowledge amenable to governmental intervention and regulation, reinforcing hierarchies of power and knowledge (Chandler 2015). Thus, resilience policies reinforce an engineering resilience, which returns the system to its original state, rather than promoting an evolutionary resilience, an essential feature of human-environment systems.

The literature has shown that resilience-building counters initial ecological resilience approaches of complexity. Thus, resilience, which entails complexity, is "not considering the constructive role of synergies and feedbacks" consequently, resilience "necessarily implies winners and losers, the latter having to 'adapt' while the former having not" (Scoppetta 2016, 36). Recently, Julian Reid (2017, 2018), a critical resilience thinker, has been concerned with the Saami people who live in the Arctic zone. Instead of praising how resilience thinking is practiced, Reid's concern highlights the possibility that colonial exploitation of Indigenous ecological intelligence will be replicated. 
Resilience in general, and as a biopolitical technology in particular, has mostly been documented in neoliberal discourses and policies (Anderson 2015, Joseph, 2013 Chandler 2012, Frerks et al. 2011, Grove 2013a, Anderson 2010, Chandler 2014, O'Hare \& White 2013, McEvoy 2013, Schmidt 2015). On the contrary, academia does not report contributions documenting resilience policies responding to forms of governing other than neoliberalism. Pelling and Dill (2006) compare democratic and authoritarian regimes' responses to disaster, including the Cuban and Chinese cases of leftist regimes managing disasters. However, additional examples of states constructing different social, political, and economic orders, detached from neoliberal policies, can offer a counterhistory of rationalities on resilience. Accordingly, Hannah (2011) highlights the lack of analysis of "biopolitical impulse of left-leaning welfare statism," and its "governmental impulse and injunction to care for the life of a population of human beings" (1035). Therefore, it is imperative to understand the calculative rationalities of resilience in nonliberal or anti-neoliberal governments to understand how resilience morphs to adapt to different governmentality, and, more critically, disclose possibilities of alternatives when building resilience.

\section{Biopolitics of alternatives}

The above literature review evidences the capillarity of governmental virtuosity to engineer nature and social life. Foucault's analysis of continuous circularity of ideas, wills, and orders to normalize the population, also unravels spaces for resistance that coexist in the entangled state/society relationship (Foucault 1978, Rabinow 2010). This section addresses the alternatives emerging from complicated interstices of regulatory 
mechanisms, and approaches alternatives from the ground up. The analysis of popular sovereignty in light of biopolitics reveals spaces for social self-organization and decisionmaking despite governmental efforts denying, disguising, or obscuring locals' political participation. Such analysis paves the way to understand immanent alternatives out of dominant strategies for future wellbeing.

\section{Biopolitics of sovereignty}

Government's virtuosity depends on reinforcing the notion of borders. Within the territory, the state pursues the population's wellbeing and prosperity, while the government organizes "things" in what it believes to be the best way (Foucault 2003). While the concept of State's sovereignty is inscribed and functions within a territory, the notion of borders fails when confronting supranational spaces. For instance, market capitalism, which expands globally (Hardt \&Negri 2004), or global hegemonic frameworks, such as resilience-building or sustainable development outlined in the previous sections.

Within contemporary state practices, including those projects to expand beyond the limits of nation-state, a collective decision making that represents the interests of the population continues to exist (Balibar 2004, Agnew 1994). In a similar vein, Hardt \& Negri (2004) acknowledge the existence of an alternative social organization that is not sovereign. Hardt and Negri elaborate their arguments through the analysis of guerrillas and peasants. They are organizations with a non-sovereign territory, with polycentric forms of decision-making, and the ability to self-organize the political, the social, and the economic. Consequently, democratic or popular sovereignty undermines such assumed 
exclusive role of the state to arrange population and their milieu. A significant contribution from Hardt and Negri's work is the understanding that social organizations have their "own biopolitical activity" which "opens up possibilities for alternative social relations" (Hardt and Negri 2004, 206-208). Thus, Hardt and Negri open spaces for approaching alternative social relations, apart from the Western-led dominant governmental normality.

Indigenous studies have shown that self-organization and self-determination have been crucial for Indigenous peoples to successfully circumvent the almighty government's disposition. For instance, US Tribes legally fought to retain the right to use peyote in their traditional medicine and religions (Wiedman 2012); the Florida Miccosukee in the US (Wiedman 2010) and the Quechua People of Taquile in Peru (Canessa 2005) successfully engaged tourism industry; Hawaii’s Molokais circumvented private investments in the pristine islands (Baker 2011). Thus, self-determination is crucial within intricate and continually negotiated relations with the State.

Among these intricate and continually negotiated social relations, Erazo (2013) discloses the ongoing sovereignty enactment among the Amazonian Rukullakta people in Ecuador. Interestingly, Indigenous people enact sovereignty while they seek alternative futures, argues Erazo. Similarly, Fixico (2013) argues that Indigenous peoples in the US have resourcefully challenged, circumvented, and adapted to Western forms of life, including market integration. Amidst global integration of development, some Latin American peasants additionally confront ethnic recognition politics. For instance, the Indians in Brazil (Warren 2001) and the comuneros in Ecuador (Alvarez 1999) - to whom this dissertation is devoted - live within ambiguous spaces between mestizaje 
practices and new Indigenous recognition policies, consequently, constraining their alternatives. In sum, despite governmental politico-legal practices enabling Indigenous peoples and peasants to build their own spaces, paradoxically, the practices of social control limit their possibilities.

\section{Transformative possibilities}

Government mechanisms limiting alternative possibilities contrast with the promotion of individuals' self-capabilities, self-reliance, self-determination disseminated through discourses and practices of sustainable development, resilience building, or popular sovereignty. Indeed, the previous biopolitical approach to the governance of nature and the social has shown hidden logics engineering the self and their milieu through what Foucault (2007) called mechanisms of security. Government organizes a series of truths through the creation of knowledge. Within the State apparatus, specialists of all kinds analyze causes to be incorporated in policymaking. Such technocracy more often than not relies on global hegemonic practices of anticipation, such as sustainable development which foresee progress, or resilience building which prevents hazards.

Specialists work with known causes, particularly environmental deterioration and increasing risk. Discursively, those causes justify the need for securing the population and its milieu. As a result, a sense of the normal continues between regulatory mechanisms and individual conduct (Anderson 2015). However, according to Davoudi and Madanipour (2015), it is the undesirable normality, the alternatives, the otherwise, that must be located in new spaces of contestation. 
Thus, crucial for social research is to address those alternatives arising out of regulatory mechanisms engineering self-capabilities. The starting point for addressing alternatives is admitting the complexity of socio-ecological relationships and the biopolitics of governing social life and nature. As stated in the previous section, through the Complex Adaptive Cycles, systems can take unknown directions when reaching the threshold of a renewal cycle since complexity entails non-linearity, uncertainty, and transformation. Then, it is important to focus on the emergent outcomes that complexity involves.

In this sense, Chandler (2015) highlights that policy interventions, per se, do not cause transformation. Instead, alternatives emerge from those self-capabilities promoted by the government. Then, Chandler proposes an intervention he conceptualizes as "the governance of the effects." It addresses those effects emerging from internal socioecological politics rather than exclusive attention to the effects of policy intervention. Then, the "governance of the effects" addresses self-capabilities promoted by policy intervention and accordingly normalized in the population. They will inform what underlies such outcomes, such as in the CAS's back loop. In doing so, emergent outcomes will be excluded from the logic of the government.

David Chandler (2014) also posits that "the interaction between emergent complex life and governing intervention is held to be open and therefore full of immanent possibilities" $(2014,49)$. Instead, he argues, liberal and neoliberal practices rely on known causes, and both governmentalities admit underlying epistemic processes (known causes) that determine the known effects or can prevent the unknown effects. However, "the unknowable is not a result of hidden determinism (as in simple complexity), nor can 
it be the result of blind chance or luck" $(2014,56)$. Then, deterministic or modernist cause-and-effect relations cannot approach complexity which entails emergent outcomes. Thus, Chandler shifts to the analysis of the unknown-unknown cause-effect relationship since "contingent outcomes only reveal concrete causality after the event and are impossible to know beforehand" $(2014,50)$. The effects of the promoted self-capabilities will reveal causalities separated from governmental reasoning. In this regard, Chandler paves the way for conceiving life from the object of governance and the radical possibilities excluded by any form of governance.

In a similar vein, Elizabeth Povinelli (2016) collects historical disturbances in "stanzas" to visualize multiplicity of scales. The upper stanza, explains Povinelli, sketches the global periods, which highlight juridical-legal narratives of catastrophic or crisis-laden events; huge events distort ordinary or chronic ones. Povinelli emphasizes that those ordinary events are hardly reflected in the global landscape; they are "quasievents;" or events that "never quite achieve the status of having occurred or taking place; they neither appear nor not happen" (Povinelli 2016, 13) - for instance, local projects, local decision-making. Thus, the bottom stanza must include the quasi-events, so when adding "all our stanzas and re-stanzas," it reveals "alternative social projects" across the practices of governance variants (Povinelli 2016, 169). Povinelli's stanzas aim to link lags from global to local, and visualize past-present inter-relational figurations, such as thresholds, scales, and performative realizations. This form of connecting the unknown local with known global facilitates understanding politics in complicated spaces.

In this context, social research furthers Anthony Giddens' approach to the analysis of social issues. According to Giddens (1984), some of the essential tasks of social 
sciences are to be found in the investigation of the boundaries given by "the significance of unintended consequences for system reproduction and the ideological connotations which such boundaries have" (282). While Giddens systemically and structurally approaches social institutions in space and time, Foucault's "art consisted in using history to cut diagonally through contemporary reality" (Foucault 2008, xv).

Thus, under a contemporary history in light of the emergent complexity theory, the emergent outcomes - feeding either Povinelli's stanzas or Holling and Gunderson's panarchical cycle - should allow pinpointing emergent causalities in time and space. In doing so, research spatially gathers politics of everyday life and politics over life coming from, and responding to, internal socio-ecological interdependencies.

\section{Conclusion: social research in entangled socio-nature governance}

Foucault's notion of biopolitics opened understandings within the tangled relationships among the State, the government, the population, and nature. Such understandings disclose the multifarious efforts governments utilize, according to their logic of governance, to fulfill the population's wellbeing. In this chapter, the literature addressed environmental governmentality, resilience building, and sovereignty to disclose governments limiting the alternatives available to locals, despite promoting selfcapabilities, self-reliance, and self-determination. Thus, the State, the government, the population, and nature navigate normality that responds to the way the government thinks. However, that governmental-induced normality has not stopped the emergence of collective actions and individuals' agency. Interstices for local decision-making and mediations emerge despite the governmentally promoted local self-capabilities. 
Paradoxically, most of the time, those local events are quasi-events. Acute and huge events usually mark a present, a future, and a past, neglecting recurring events (Povinelli 2016), denying alternatives that the non-linearity of complexity involves. This literature review has shown that local decision-making and mediation must inform the complex adaptive systems beyond the limits of governmental logic. Thus, the social scientist must document, trace, and record decision-making and mediations, emerging from the interstices of juridical-legal State apparatus to break with government's disposition of normality. 


\section{Chapter III}

\section{Untangling Comuneros rural lives in the Ecuadorian Pacific coast}

The deep blue of the Pacific Ocean hypnotizes, the salty breeze relaxes; suddenly, the endless sound of the waves fades with the noise of rushing villagers in the peninsula of Santa Elena. They are busy. The sun is splendid. The villagers are setting up their cabanas on the beach. They have to be ready for the incoming tourists. Villagers no longer collect shrimp larvae in the surf zone, as they used to a couple of decades ago. In the peninsula, as Santa Elena is known, villagers used to live surrounded by pristine beaches interspersed with mangroves in the mouth of clear, low-flow rivers. Later on, Santa Elena's beaches were dotted with numerous villagers harvesting shrimp larvae. With colorful red meshes tied to floaters made out of mangrove, the villagers captured shrimp larvae from the endless waves breaking into foamy bubbles.

Currently, many of those shrimp larvae collectors are owners of small tourism businesses at those no-longer pristine beaches. Figures 2 and 3 show profound changes in the comuna Montañita, in the northern rural parish of Manglaralto. An untouched beach in the 1970s transformed into a surfing hotspot after forty years, and today, the sound of the waves continues harmonizing villagers' lives, sunsets close each day in the normal cycle, while novel actors and stakeholders have arrived at the peninsula. How did Santa Elena change so quickly? What caused social and ecological changes?

In this chapter, I analyze multiple stressors pressuring everyday lives on the coast of Ecuador. By stressors, I refer to: a) Political and judicial changes in Ecuador, b) 
natural processes in complex coastal topography, and c) seaside villagers' desire for development and progress. All of these stressors are dynamically interconnected while reshape the ecological landscape. I approach the ecological landscape of Santa Elena as a complex subset of layers interplaying around future progress and the everyday lives of rural villagers. Among the different subset of layers, the State and the government are intense stressors (Chapter 2). In Ecuador, governments adopted neoliberal state practices from the early 1980s (Pineo 2007). Since 2007, a government countering neoliberal state practices ruled the country for a decade. The goal of this chapter is far from an economic critique of both governmental practices. Instead, I focus on "the purpose of the governmental actions and the means by which it is achieved" (Davoudi and Madanipour $2015,4)$ in order to understand social and economic changes in Santa Elena, in general, and the rural communities in particular.

In the first section of this chapter, I analyze the effects of neoliberal state practices upon Ecuador during three decades, despite the political instability that characterized the country during the 1990s and early 2000s. The second section addresses ten years of anti-neoliberal state practices inaugurated on January 15, 2007. In the third section, I trace interplaying actors pressing Santa Elena's new beginnings and adaptive processes in the aftermath of climatological impacts and governmental interventions. I analyze the intricate processes of local development and local politics in Santa Elena to identify struggles on developmental, territory, and identity issues additionally stressed by climatological impacts. In the final section, I argue that the comuneros, rural villagers in Santa Elena, continuously look for and adapt to alternative futures despite governmental logics. 


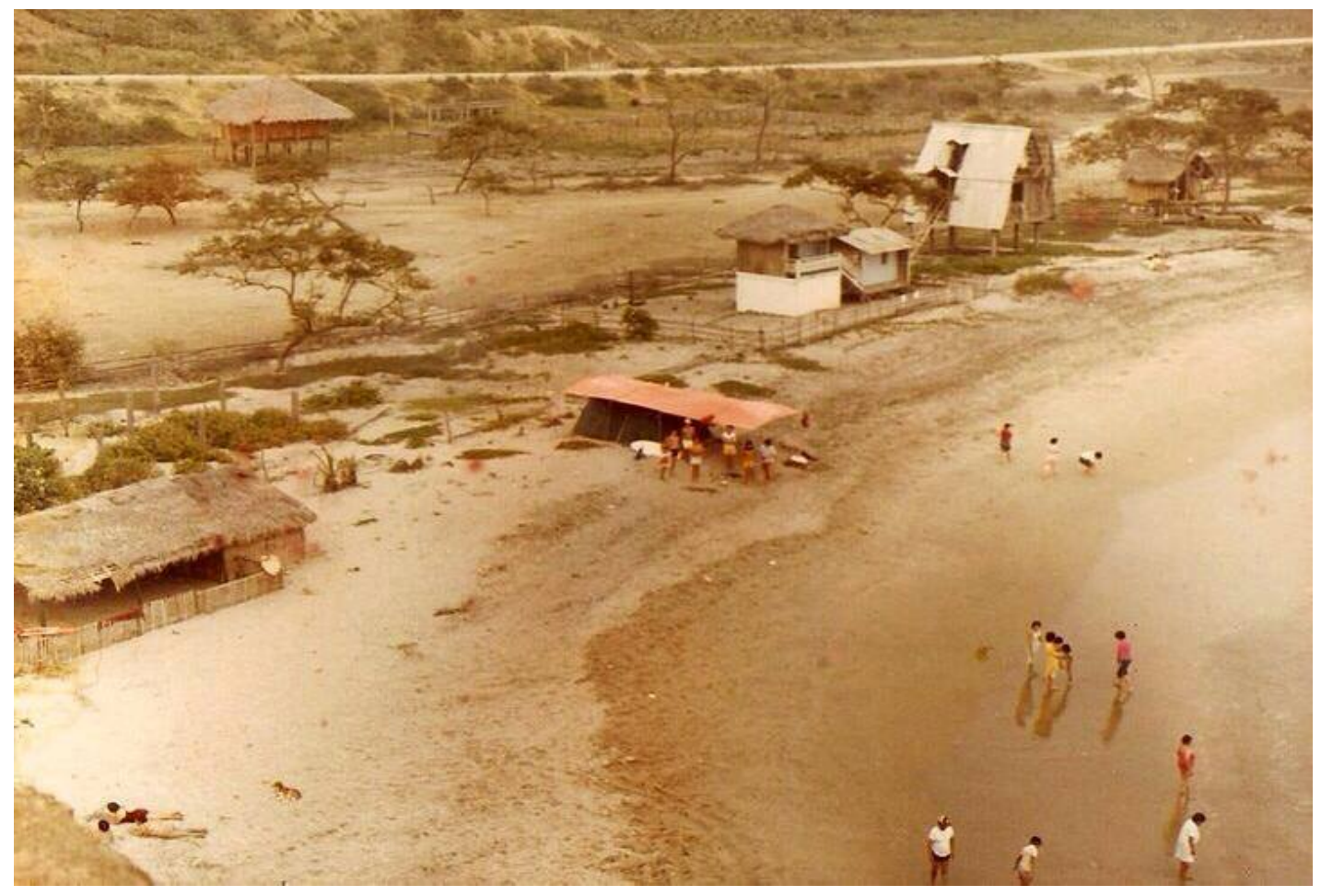

Figure 2. Comuna Montañita in the 1970s. Source: Amigos del Patrimonio de Santa Elena

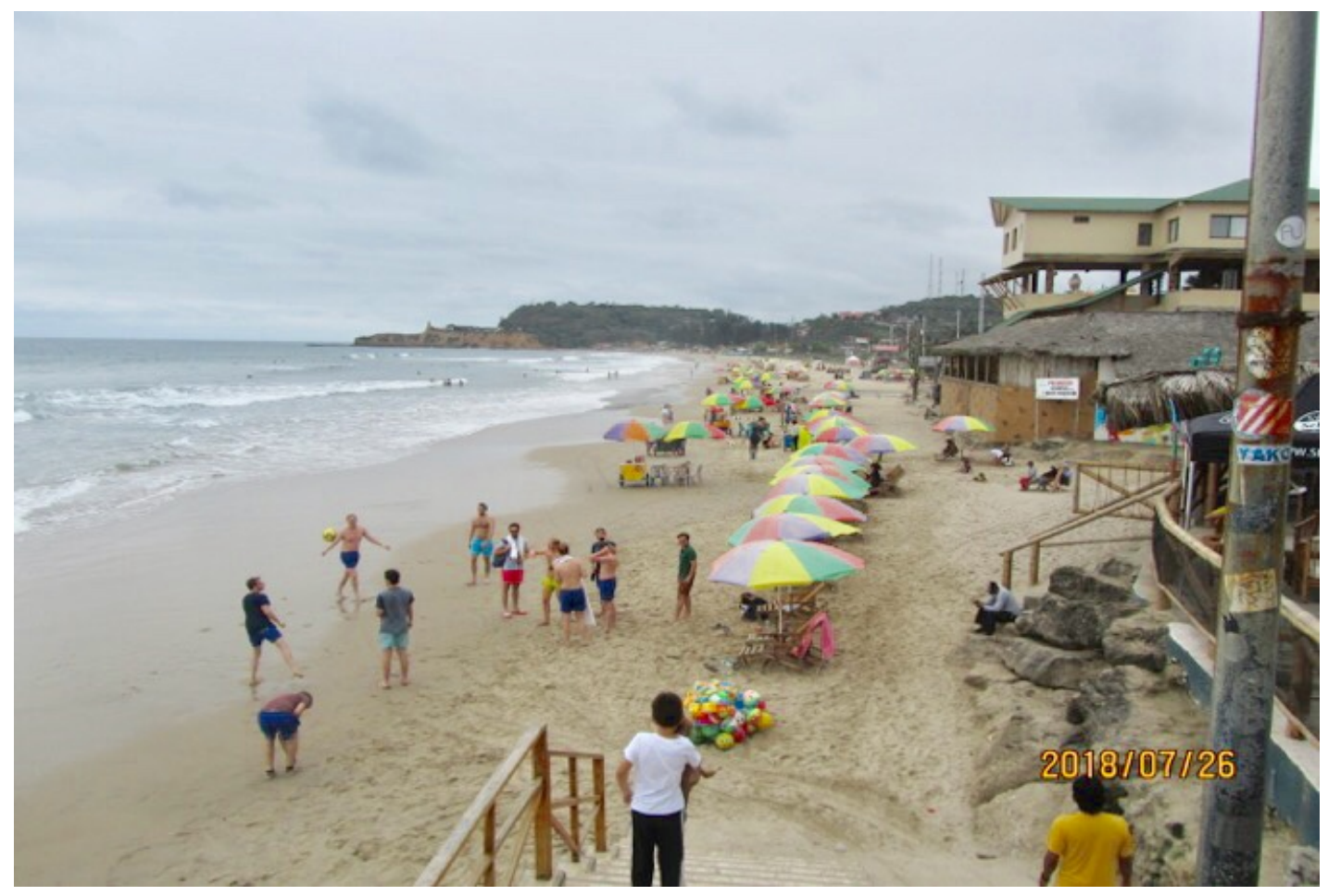

Figure 3. A day of low tourist demand at Montañita in 2018. Source: Author 


\section{Ecuadorian governments and neoliberal policies, from the 1980s to early 2000s}

Ecuador began to apply neoliberal state practices in the early 1980 s after the military regime returned democracy to the country. Captivated by the development discourse to reduce poverty, Ecuador decided to modernize in pursuit of the population's future progress. The panacea of development would bring economic growth as well as a solution to social problems, inequalities, and poverty. However, development critique has unpacked external and northern global dominance, directing how countries must modernize, progress, or develop (Ferguson 1994). Moreover, post-development scholarship has revealed poverty as a crafted discourse to justify US interventionism in the aftermath of WWII (Escobar 1995, 2007).

This section draws upon two related discourses and practices: neoliberal state practices and development. The rationale and practices of development deepened during the last two decades of the twentieth century, when governments adopted several neoliberal recipes supported by US-based global influencers such as IMF, WB, IDB, USAID. Briefly, neoliberal state practices de-regularize the managerial role of the state by promoting the privatization of services (education, health, telecommunications). Furthermore, neoliberalism "combines a commitment to the extension of markets and logics of competitiveness" (Peck and Tickell 2002, 381). Additionally, neoliberal practices rely on the expertise of ruling, while the idea of wellbeing becomes, more often than not, synonymous with Northern development, building infrastructure that actually supports the market economy. Neoliberalism is not a unique recipe executed by a government. Neither is it a "homogenous doctrine" (Reid 2018). Neoliberalism mutates; 
it has transformative and adaptive capacity by which it neoliberalizes all spaces (Peck \& Tickell 2002), as happened since Ecuador returned to democracy in 1980.

Ronn Pineo, in his book Ecuador and The United States: Useful Strangers (2007) depicts the long-lasting influence of the US on Ecuadorian governments. According to Pineo, state practices during the late 1980s lessened state control over the financial sector, decontrolled currency exchange, lowered tariffs favoring foreign investment regulations, maintained wage hikes below the rate of inflation (which was growing), and raised interest rates. Pineo reveals how the IMF fostered currency devaluation. The motivations for embarking into IMF funding were a low-intensity military action in the southern border with Peru in 1981, and the subsequent El Niño event that flooded coastal regions in 1982/1983 and weakened the country's development plan. According to Pineo, the primary goal of the 1985-1988 development plan was the economic liberalization of the state, while the IMF swiftly rewarded Ecuador with new loans in 1985 and 1986. In this way, Ecuador entered into US-influenced neoliberal recipes, which continued the functioning of the country regardless of who occupied the presidential office.

Ecuadorian governments continued a tendency to follow neoliberal recipes, USbased financial assistance, and devoting massive proportions of its discretionary revenue to debt service. Legal frameworks enacted during the 1990s reveal the neoliberal practices that were regulating Ecuador. For instance, the Law of Modernization approved in 1993 promoted disinvestment, privatization, concessions, and state reform. It also aimed to reduce the bureaucracy that settled in the capital city by transferring several functions and roles to the municipalities. However, a viable juridical, financial, and 
planning framework was absent in the state. The law complicated municipal management and rural cantons' improvement despite having the territorial administration. La Torre et al. $(2015,59)$ summarizes Ecuadorian neoliberal practices during the 1980s and 1990s in the following excerpt:

"A rescheduling of the debt was negotiated, subject to the direction and economic adjustment plans of international financial institutions (IFIs), such as the World Bank. These programs prioritized fiscal solvency and inflation control, which was to be achieved through market liberalization, privatization and integration, and specialization within the world economy. [...] While oil continued to be the main export, new products were introduced, such as cut flowers, fruit juice and preserves, shrimp and garments, which served as leading axes for capital accumulation."

Indeed, shrimp farming experienced a boom in the 1980s-1990s. Like any other extractive industry, shrimp farming needs large extensions of land. Thus, the shrimp business in Ecuador spread "toward communal mangrove areas where fishermen, shellfish gatherers, and charcoal makers had historically secured their livelihood" (La Torre 2015, 62). El Niño Phenomena during 1997/1998, in addition to soil overexploitation, facilitated a severe disease outbreak, almost collapsing the shrimp industry at the end of the 1990s.

During the 1990s, a series of natural disasters in the Andes and an El Niño phenomena disaster during 1997/1998 along the coast (See Chapter 4) aggravated economic collapse in Ecuador. Internationally, oil prices fell, thus, Ecuador confronted a serious financial crisis in 1998 and 1999. By the year 2000, the government aimed to 
stabilize the country's finances by abandoning Ecuador's national currency, the Sucre, and adopted the US dollar as the official currency (Arsel 2012, Eaton 2013, Gamso 2016). This motivated a massive emigration of Ecuadorians, mainly to Spain, Italy, and the US, while remittances became an essential input to Ecuador's GDP.

Moreover, Ecuador underwent political instability and social unrest during the 1990s and 2000s resulting in several Presidential impeachments and resignations. Thus, between 1996 and 2006, six different individuals held presidential office. In 2007, Ecuadorians elected a new government, this time, a left-led government, which ruled the country during the next decade. In the next section, I examine the leftist rationale governing Ecuador for a decade.

\section{A decade of anti-neoliberal state practice in Ecuador (2007-2017)}

Scholars have viewed the anti-neoliberalism that arose in Ecuador as both a critique of the irrationality of governments responding to neoliberal deviances, and as a return to leftist policies in Latin America (Goertzel 2008, Becker 2013, Coraggio \& Laville 2014). Since the early 1990s, an ideology called Socialismo del Siglo Veintiuno or Twenty-first Century Socialism sought to challenge neoliberal practices operating in Latin America (Macdonald and Ruckert 2009). In January 2007, the Ecuadorian leader of the Twenty-first Century Socialism, Rafael Correa, was elected President. Correa's discourses consistently addressed social inequalities arising from the "long neoliberal night” (EFE 2009, Correa 2009). The newly inaugurated government persistently critiqued the failures of neoliberalism and indicated its intention to detach the country from neoliberal development policies. 
Accordingly, the leftist government shall "correct newly identified - or newly created - deficiencies" (Li, 2007:19). Thus, in 2008, Correa's government reestablished the regulatory functions of the state by enacting a new Constitution, which contained highly philosophical principles on nature-society relationships. The Constitution's ethos entails a systematic state planning to attain good relationships in the country. Thus, Article 3 establishes the state's principal duties, among them "planning national development." The Constitution clarifies the planning duty in Article 275 thus:

"The State shall plan the development of the country to assure the exercise of rights, the achievement of the objectives of the development structure, and the principles enshrined in the Constitution. Planning shall aspire to social and territorial equity, promote cooperation, and be participatory, decentralized, deconcentrated, and transparent." (Emphasis added)

Rather than a simple relation between the state and the society, the rationale of development planning in the Ecuadorian Constitution locates the state government's functions as the "internal logic of an administrative apparatus" (Foucault, 2008:93). Additionally, Article 277 identifies the general duties of the state, among them, "to direct, plan and regulate the development process." Article 279 explicitly creates the Sistema Nacional Descentralizado de Planificación Participativa or Decentralized Participative Planning National System, the primary function of which is to organize planning for Ecuador's development, by combining an array of processes, entities, and instruments, and issuing the national development plan. The Secretaría Nacional de Desarrollo or National Secretariat of Development is the planning executing agency 
(Article 279), while the national development plan is the instrument between the central government and decentralized autonomous governments (Article 280).

Within a decade, the Ecuadorian Development Secretariat enacted three national plans, all of which emphasized how the state can achieve building a future by regaining its planning, regulatory and controlling faculties: 1) The National Development Plan 2007-2010, the Plan for Citizen's Revolution was described as "an alternative and democratic agenda to reach the sustainable and equitable Ecuador." This was modified after President Correa's re-election in 2009, birthing the 2) The National Plan for Good Living 2009 -2013, Building a Plurinational and Intercultural State. The second presidential re-election in 2013 enacted 3) The Good Living National Plan 2013-2017, A better world for everyone. Overall, the three plans clearly detailed objectives, strategies, programs, and responsibilities in each public, social, and political sphere toward building future wellbeing in Ecuador. The internal policy on planning spread throughout each remote hamlet in the country, guiding and controlling Ecuadorians' everyday lives.

Thus, planning and spatialization were crucial for the anti-neoliberal rationale to achieve economic sovereignty and development. Correa's second presidential term reinforced the planning criterion that defined the appropriate role of the state in the economy. Thus, the 2013-2017 National Plan affirms: "Good Living cannot be improvised-it must be planned" (SENPLADES, 2013:14). In the foreword section of the 2013-2017 Plan, Fander Falconí, then Secretary of National Planning and Development explained the legal ensemble underpinning the planning capacity of the state: 
"One of the primary tools in Ecuador's political process has been its planning. The Constitution links planning directly with building citizens' rights. The National Decentralized Participatory Planning System (SNDPP) was created in the 2008 Constitution (Article 279) and comprises the National Planning Council, its technical secretariat, the sectorial public policy councils of the executive branch, national equality councils, planning councils of decentralized autonomous governments, citizens' sectorial councils and other mechanisms for participation. The basic units for participation in the system are communities, hamlets, neighborhoods, and urban parishes (Article 248). The system is governed by the 2008 Constitution, the General Public Planning and Finance Code (COPFP - 2010), the General Law on Citizen Participation (2010) and the General Code of Territorial Organization, Autonomies, and Decentralization (COOTAD - 2010)" (SENPLADES, 2013, 16).

The leftist government decentralized governance through the General Code of Territorial Organization, Autonomies, and Decentralization (CTOAD) and the creation of the Autonomous and Decentralized Governments (ADG). Indeed, ADGs are like a reinvention of the municipal roles which introduced additional competences to the local government. Essential for my research, the CTOAD decentralized tourism and risk management to the municipalities while planning became the model towards local development. Rural and urban parishes also have the option to become an autonomous and decentralized government as they also need to plan their development and territorial ordering. However, as I will show throughout this research, a lack of legal harmony persists in practice. 
Indeed, territorialization was another national strategy to "bring about a new relationship between the human being, nature and its environment of life" (SENPLADES 2009,371 ). According to the national plan issued in 2009, the territory has two characteristics: firstly, it is a complex system in constant transformation: "the territorial might not be conceived merely as the physic-spatial, rather, as an actual concentration of culture interacting with nature" (372). Secondly, the territory is a flexible instrument to achieve the de-concentration of executive power. Thus, without neglecting the traditional (and current), administrative distribution of the state - comprising provinces, cities, cantons, and parishes - the government established nine zones of territorial planning to disperse the state apparatus to different scales while locating the government closer to the population. In this way, the government aimed to "warrant the rights of health, education, household, food, work and water" (SENPLADES 209, 401) to promote the endogenous development model, pivoting the anti-neoliberal economic ideal; and to rationally use natural resources.

Government technicians from the National Secretary of Planning and Development mainly promoted this new model of territorialization, structuring governmental agencies according to the planning zones, while functioning according to the national plans. Territorial organization together with planning entailed "the same continuous and cyclical process" aiming "to orient interventions to improve the population's quality of life and to define policies, programs, and projects applicable within the territory" (SENPLADES 2009:400). Such tailored territorial governance relies on the subsidiary principle mentioned in the Constitution and clarified in the 2009 National Plan of Development: 
"Complementarity and subsidiarity among levels of the government are basic principles of planning and territorial management" (SENPLADES 2009, 129).

The subsidiarity principle enlightening the anti-neoliberal government pursued a total intervention by decentralizing and de-concentrating administrative functions from national to local governments.

The General Code of Territorial Organization, Autonomies, and Decentralization CTOAD, a foundational legal framework on territorial organization, also appeals to this principle. In article 3, the law states:

"Subsidiarity supposes to privilege the management of services, competencies and public policies by the levels of government closest to the population, in order to improve their quality and effectiveness and achieve greater democratization and social control of them."

Overall, CTOAD regulatory framework established territorial management, decentralization, and de-concentration in the country. Mainly, the law describes the functions and responsibilities of all type of ADGs: Regional, Special Regimes, Prefecture, Municipality, and Parish levels. The legal framework required a local Plan de Desarrollo y Ordenamiento Territorial or Plan of Development and Territorial Management for each Autonomous and Decentralized Government (SENPLADES 2009, 507). Within three years, consultants throughout the country elaborated roughly one thousand plans, which included geographical data, population data, and economical production subsystems (Lopez, 2015).

The government needed to collect a large quantity of data from each site to inform territorial management and planning. For instance, once tourism appeared as an economic 
sub-system in all ADGs, the Ministry of Tourism should provide information about tourist infrastructure and attractions. Since 2007, nationwide, the government has inventoried each natural or intangible resource. In the case of tourism, I was one of the numerous consultants who inventoried each tourist attraction, identifying, coding and orderly recording each physical, biological and cultural factor that, actually or potentially, could contribute to the country's tourism offering. Tourism consultants cataloged natural attractions such as rivers, beaches, falls, ecological reservations, forests and cultural heritage, such as handicrafts and gastronomic festivities. As was done in tourism, censuses were also conducted in agriculture, livestock, fishing, forest reserves, environment, culture and heritage, and risk and vulnerability. In addition to the resources inventory, urban and rural ADGs' plans required data about production and business. Thus, governmental offices updated cadasters of every kind of supply. In the case of tourism, the Ministry of Tourism registered each hotel, restaurant and leisure business. Similar to the inventory process, governmental offices collected information by deploying consultants to the most remote hamlet of the country.

Development planning increased exponentially due to the anti-neoliberal government introducing a Sumak Kawsay or Good Living as a planned relationship between humans, nature and the environment. Paraphrasing Arsel (2012), while Arturo Escobar supports the idea of Good Living introduced by the Twenty-first-century Socialism in Ecuador, other scholars - and politicians as well, characterize those left-led governments in Latin America, "as corrupt authoritarianism buttressed by neo-populism" (Arsel 2012, 151). On the one hand, argues Arsel, the case of Ecuadorian anti-neoliberal ruling seems to be a "transformative nature of development policies" (ibid). On the other 
hand, anti-neoliberalism could have been going back to plans for development that were introduced during the 1970s.

In August 2017, Lenin Moreno, former Vice-president of Correa's first term, was democratically elected President of Ecuador. Despite his initial connection to Correa, he has consistently distanced his government from Twenty-first-century Socialism. Instead, Moreno's discourse has shifted to what he calls Toda Una Vida, or "A Whole Life," to signal the population's wellbeing from conception to death, while distancing the discourse from a human-environment relationship. In the meantime, Moreno's political decisions, according to the news, are seemingly reverting to neoliberal governmentality. The IMF is again having an active role in Ecuadorian governance, and uprisings have returned to the country. The new government has opened a new tipping point in Ecuadorian politics. A new uncertainty appears between the potential return to the neoliberal political instability, or the possibility of continuing with the last decade of leftled governance. Despite the neoliberal or anti-neoliberal rationale, the government is a powerful driving force arranging socio-ecological relations. The following section addresses the effects of neoliberal and anti-neoliberal state practices in the peninsula of Santa Elena.

\section{Struggles and adaptation in Santa Elena's rural coast}

The Province of Santa Elena is located in the westernmost region of continental Ecuador, occupying 1452.8 square miles. The waves of the Pacific Ocean break west along 112 miles (180 kilometers) of shoreline, while the Chongón-Colonche mountain range, which crosses $330 \mathrm{~km}$ southwest from the coast of Ecuador, borders the northeast 
of the province of Santa Elena. Politically, the Province is divided into three cantons: Santa Elena, Salinas, and La Libertad. Santa Elena municipality (or canton) extends $1,416.57$ square miles, roughly $98 \%$ of the province. The canton of Santa Elena has a municipal capital called Santa Elena and seven municipal parishes. The municipality of Santa Elena also rules the sixty-eight common property communities or comunas scattered throughout the rural areas.

Echoing the deep attachments to place expressed by the rural coastal inhabitants of Colombia, described by Arturo Escobar (2008), for the comuneros inhabiting the Province of Santa Elena, the place continues to have a critical meaning. The comuneros, as rural villagers are known in Ecuador, have a deep attachment to their land, which they consistently call Tierras Ancestrales or Ancestral Lands. Indeed, archaeological work has shown that the Las Vegas cultural group settled in Santa Elena 11,000 years B.P. (Stothert 1985). Similarly, archaeological work has shown that the Guancavilcas were the last pre-Columbian society living in the western coast of Ecuador, in what is now the Ecuadorian Provinces of Manabí (northwest), Santa Elena (west) and Guayas (southeast). Additionally, ethnohistorical analysis has traced the negotiations locals undertook to keep their population isolated until the early 1900s (Alvarez 1999, 2002).

In 1911, Anglo Ecuadorian Oilfields Limited, a British oil company, drilled the first oil shaft in south Santa Elena, creating numerous changes in the peninsula. During the 1950s, northern Santa Elena continued maintaining pristine beaches, while a few communities shipped wood and fruits to the port city of Guayaquil, 87 miles away from Santa Elena. Accessibility to the north of Santa Elena was also a factor in keeping comuneros distant from abundant state developmental interventions until the late 
twentieth century. To understand the several stressors affecting comuneros' lives, in this section, I describe climatological, economic, political, and identity issues in the Province of Santa Elena, and the Manglaralto Parish in particular.

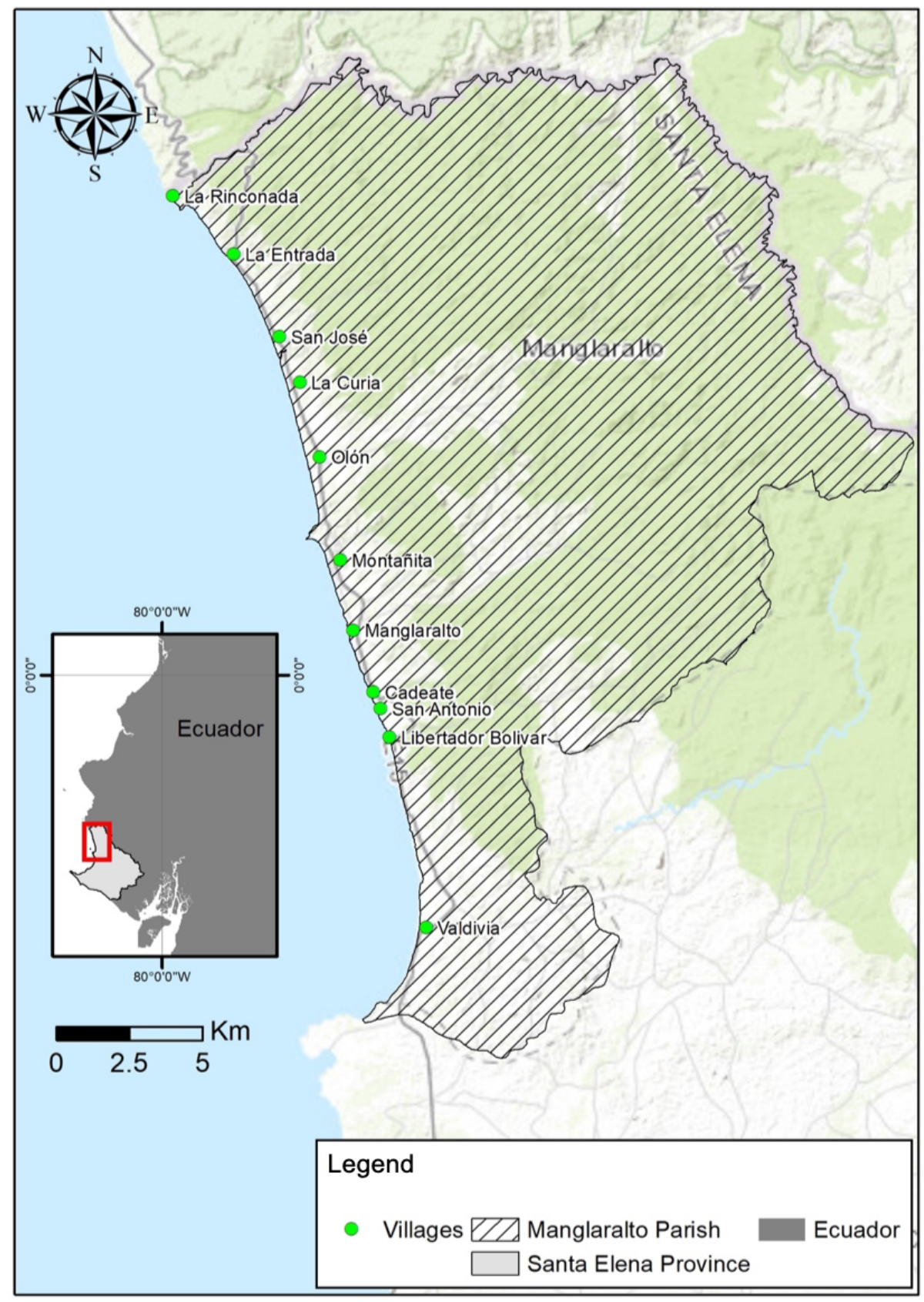

Figure 4. Map of Manglaralto Parish and coastal comunas. Elaborated by Daniel Garces 
Manglaralto has nineteen comunas, including the parish capital Manglaralto. This research mainly focuses on the northern parish of Manglaralto, which is located between the Pacific Ocean and the Chongón-Colonche range (Figure 4). In an extension of 207 square miles (536.5 square $\mathrm{km}$ ), the Manglaralto parish has several low-flow rivers and streams that flow down west in a watershed that become estuarine zones close to the Pacific Ocean. The name Manglaralto is derived from the vast extensions of altos manglares or high mangroves that existed in this territory decades ago. From south to north, the rivers are Valdivia River, Atravezado River, Manglaralto River, Olón River, Montañita and some other streams. Overall, rivers in the Manglaralto parish do not have a consistent, over-ground flow; instead, rivers in this region have a low-flow year around. To the west, river mouths intersperse with sandy beaches, tidal ponds, and seaside villages.

Thirteen comunas are next to the shoreline, while six are next to the mostly settled Chongón-Colonche range foothills. Some villages have taken their name from the rivers next to or crossing them, for instance, the communities of Valdivia, Manglaralto, Olón, Montañita, Atravezado or Libertador Bolívar. The highway E-15 or via Troncal del Pacífico connects Manglaralto with the municipality of Santa Elena from the south to the northern province of Manabí. Thus, the Manglaralto parish and its comunas are part of the tourist corridor named Ruta del Spondylus. Archaeological work has shown that the aboriginal Valdivia people settled in this region 3,500 years BC. Indeed, some villages continue handcrafting pottery with pre-Columbian techniques, particularly in the comuna Valdivia. 
According to the 1982 Ecuadorian population census, 14,961 people lived in the Manglaralto parish. The last census, carried out in 2010, reveals 29,512 people inhabiting this parish. Thus, in three decades, the population of the Manglaralto parish almost doubled. It is important to highlight that the Ecuadorian national population increased by $82 \%$ in the same period. Clearly, within this twenty-eight-year period, Manglaralto's population growth exceeded the national average. During those decades, comuneros experienced two catastrophic events. Specifically, the El Niño Southern Oscillation impacted the coast of Ecuador several months during the years 1982/1983 and 1997/1998. The next section reviews the effects of those disasters, which are closely related to climatological issues on the Pacific coast.

\section{Climatological issues in Santa Elena}

The climate in the province of Santa Elena is dry and arid (GAD-PSE 2015). The dry condition results from a slight oceanic evaporation process that, upon entering the continent, does not produce precipitation during most months of the year while the influence of the Humboldt Current, which flows northward along the South American Pacific coastline, is preponderant (PMRC 1993). Moreover, the Inter-Tropical Convergence Zone brings annual and interannual climate variability. In this region a lowpressure zone near the equator, the northeast and southeast trade winds converge, producing a plethora of precipitation when air rises due to solar heating (UNDP 2013). Along the Ecuadorian coastal region, rainfall and clouds from December to April characterize the rainy season with temperatures between $75-82^{\circ} \mathrm{F}$, while the dry season is from June through November with lower temperatures, between $68-77^{\circ} \mathrm{F}$. Some occasional rains fall during the dry season because the Chongón Colonche Range blocks 
the mass of air coming from the Pacific Ocean, drizzling the shoreline during the summer.

The phenomenon called El Niño is another phenomenon with atmospheric, hydrological, or oceanographic origins. Oceanographically known as El Niño Southern Oscillation (ENSO), a phenomenon that is a very complex anomaly that includes changes in both the ocean and the atmosphere (Gasparri et al. 1999). The axis of circulation of ENSO is the equatorial line of the Pacific Ocean. The temperature of the ocean increases as it moves towards the American continent, raising the sea level, and hindering the natural drainage of rivers flowing into the ocean.

ENSO events in Ecuador have been recorded in the following years: 1925, 1934, 1941, 1953, 1957, 1958, 1965, 1969, 1972-1973, 1976-1977, 1982-1983, 1986-1987, 1997-1998, 2002-2003, 2006-2007 and 2009-2010 (UNDP 2013). However, ENSO’s frequency, occurrence and intensity stimulate constant debates in Ecuador. On the one hand, government officials, whom I interviewed, assert that ENSO occurred in 2012 and 2015, but there is no official record of that.

There are official reports of high-intensity rainfall during those years and contingency plans implemented in several areas (GAD-MSE 2009). On the other hand, the news consistently announced the "potential intensity" of a "probable" ENSO, while remembering the catastrophic effects of previous impacts (El Universo 2015, 2016). Officials and the news media agree on the catastrophic effect of the ENSO in Ecuador. Indeed, on the coast, precipitation levels increase starkly. A report issued by the Corporación Andina de Fomento (CAF 1998), a development bank operating in Latin America, states: 
"According to the analysis, all ENSOs (except in1969), were characterized by generating [in Ecuador] an excess of precipitation that exceeded averages in 40 and $130 \%$ of the normal years. The highest values of the anomaly in percentages, they occur in the semi-arid zones of the coast to the southwest of the littoral (the peninsula), because the normal levels of precipitation in them are very reduced" (CAF 1998, 26)

The extraordinary events of El Niño from 1982-1983 and 1997-1998 increased the sea level between $0.20-0.40$ meters ( $0.7-1.31$ feet) above the average, causing coastal erosion at the shoreline Cornejo (2007). The most critical condition threatening the beaches of Santa Elena occurs when swells, spring tides (higher than normal tides) and El Niño occur simultaneously, explains Sanchez, an expert in Santa Elena's beaches (Interview with author, June 18, 2018). Sanchez confirmed that this happened in the years 1982-1983 and 1997-1998. Furthermore, an OXFAM report points out that the Santa Elena was the most flooded region in Ecuador during the decade 1988-1998 and, paradoxically, the most exposed to droughts during the same period (Demoraes and D'Ercole 2001).

The El Niño phenomenon also brought profound economic changes to Santa Elena. By the late 1970s, the expansion of the shrimp industry had deforested vast stretches of mangrove along the Coast of Ecuador. However, as Odum and Arding (1991) state, the exceptional El Niño runoff in 1983, accompanied by river surges, favored exceptional shrimp and post-larvae production. Post-larvae harvesting was essential to seaside villagers' livelihood during the years following the 1982-1983 ENSO. It was 
usual to observe beach landscapes portraying locals collecting shrimp larvae with finemeshed nets in the surf zone where small waves break.

Many of the current leaders I interviewed, enthusiastically recalled those years working in the shrimp-farming industry in Santa Elena. Many of them were larveros or shrimp larvae collectors, while others worked in the laboratorios, as shrimp nurseries are known in Ecuador. Larveros used to make their own nets supported by a mangrove frame. Historically they have been making nets for feeding their communities with artisanal fishing. However, being larveros allowed them to diversify their livelihood economy. Larveros ' or shrimp larvae collectors' contribution to the national shrimp industry tripled in fifteen years, from 7 billion seed shrimp in 1986 to 24 billion in 2000 (Arriaga 2000). By early 1990s, the Manglaralto Management Plan (PMRC 1993) estimated that more than $80 \%$ of the economically active population in the parish of Manglaralto collected shrimp larvae during the aguajes, periods of high tides.

In the mid-1990s, artisanal larvae collection started diminishing. Firstly, the shrimp-larvae nursery introduced new technologies to increase production and profitability. Secondly, studies began to show side-effects of the artisanal larvae collection on the ecosystem ${ }^{5}$. An analysis conducted in 1993 revealed that only $18 \%$ of species captured in the fine meshes fit shrimp-industry requirements. Eighty-two percent of the by-catch included juvenile fish, crabs, and other species (Robadue 1995). However, it was the El Niño phenomena in 1997-1998 that caused the collapse of larvae harvesting (CAF 1998). Indeed, according to local leaders, such phenomena profoundly changed their livelihoods. 
"Before the El Niño phenomenon, [shrimp larvae harvesting] was my job, it supported me. However, when El Niño phenomenon came, the first thing to be destroyed were the shrimp nurseries' infrastructure and shrimp farms [...]. Now what are we going to do? We asked. I decided to build a small store and put the first furniture I made out of guadúa cane on display" Luis Coronado, former President of the Cabildo at Libertador Bolívar (interview with author, June 16, 2018).

Similarly, Smeling Suarez, former president of the Santa Elena's Communities Federation, born and raised in the village of Libertador Bolívar argues:

"The shrimp larvae we caught disappeared. Community tourism and handicrafts appeared, and [both the] dynamization of economies and the territory issue were framed" (Interview with author, June 22, 2018).

In the aftermath of ENSO phenomena in 1997-1998, recorded as one of the most substantial ENSOs in terms of its impacts on Ecuador, people in Santa Elena strengthened their capacity to rebuild their social lives, looking toward the uncertain future, while keeping their attachment to their communal land. Indeed, communal management of rural lands continues to be another stressor in Comuneros' lives.

\section{Territory and communal management in Santa Elena.}

Territory, ancestral land and communal land are concepts that consistently appear in Santa Elenians' everyday discourse. The discourse on land and territory in Santa Elena emerges from a long-lasting legal framework ruling their lives since 1937, the Ley de Organización y Régimen de Comunas. It is popularly called Ley de Comunas or Law of 
Communes. Consequently, those settlements started to be known as comunas. In this section, I analyze the struggles of territorial administration among the comuneros after the enactment of the law, which provided recognition to communities and hamlets that have held their land for at least thirty years.

Comunas' territory and resources are owned and managed collectively. Since its enactment, the law designated the Ministry of Agriculture and Livestock to register and control communal lands. Nowadays, the same ministry continues managing the comunas of Santa Elena and legally appoints comuneros. Locals who aspire to become a comunero legally make a petition to the Cabildo Assembly. After communal approval, the Cabildo staff submit a request to the Ministry of Agriculture to update the information. Initially, the Instituto Ecuatoriano de Reforma Agraria y Colonización or Ecuadorian Institute for Agrarian Reform and Colonization regulated the Comunas. The anti-neoliberal government closed this department in 2011. Since then, the Subsecretaría de Tierras y Reforma Agraria or Land and Agrarian Reform Secretariat, a Ministry of Agriculture department, specifically regulates and controls comunas. However, Alvarez (2002) posits that the Law of Communes evidences a State paternalism which, ultimately, controls Indigenous lands.

The 1937 Law of Communes also stipulated comunas administration. Comuneros must gather in community assemblies chaired by the Cabildo or Community Council, which legally represents the comuna in any external activity or connection with the local and national government. Each December, comuneros democratically elect the five members of the Cabildo: President, Vice President, Secretary, Treasurer and Síndico (translated Trustee), whose leading role is to measure any plot in the comuna. The law 
does not establish any budget for the comuna, or for the Cabildo members who volunteer for such positions for one year. They organize Communal Assemblies and execute any decision agreed by the comuna in the Community Assembly.

All inhabitants of a comuna can attend and participate in the assembly, while only legally recognized comuneros have decision-making power. In the community assembly, comuneros reach consensus on everyday issues, discuss ideas for community progress, and make decisions democratically. At least once a month, the comuneros gather in a Community Assembly, but in case of any particular concern, the Cabildo can request extraordinary meetings. The Cabildo's main concerns are territory, environment, economic development, health issues, or any other activity that could potentially positively or negatively affect the population. Overall, the Cabildo's central role entails comuneros' wellbeing. In doing so, the Cabildo not only deals with local issues, it extensively deals with the elected leaders' network and with the local and national government, as well as private and non-profit organizations.

The Community Assembly minutes that I have perused reveal extensive discussions regarding any internal conflict that was seen as disrupting comuneros' wellbeing, as well as any external driving-force trying to infiltrate their community. During the assembly, comuneros discuss quotidian conflicts, e.g., plot possession, conflicts between the boundaries of their parcels; permits to build their small business, festivities, among other matters. The minutes also reveal heated discussions about external projects that outsiders bring to the village, including NGO or governmental projects. Once the community assembly makes a decision, the whole community respects the resolution, revealing communal organization and decision-making as key features of 
Santa Elena's comunas. Internal conflicts continually flourish, but external projects trying to get into the village prompt the comuneros to consistently restate their communal ties and their collective land ownership.

According to Becker (1999), the Law of Communes in Ecuador had an assimilationist attitude, following liberal policies governing Ecuador in the early 1900s, which aimed at social control of local lives. Silvia Alvarez $(1999,2002)$, who wrote the first anthropological work in this region, revealed that the Law of Communes worked differently on the Coast. Firstly, Alvarez (2002) highlights that the comunas in Santa Elena are "historically communal lands" (7) rather than those new comunas constituted to get public services after the Law of Communes, as occurred in other regions in Ecuador. Secondly, Alvarez (1999) critiques the Law of Communes because it introduced a European model of democracy which replaced the Cacicazgo, the customary kinship privileges and leadership previously ruling coastal areas of Santa Elena. The Agrarian Reform introduced in the 1960s also created land disputes in Ecuador (Becker 1999). In this regard, Alvarez (2002) also argues that the new law favored Santa Elena's native people, since the agrarian law recovered the notion of "community" and "communal organization" throughout the country.

Although the Law of Communes reinforced common-property rights while providing autonomy to manage a communal territory, Comuneros in Santa Elena have circumvented capitalist land grabbing. The 1937 Law of Communes, the 1964 Agrarian Reform, and the 2016 Law of Lands all prohibit individually selling the common land, but also lack enforcement mechanisms to prevent possible land trade (Herrera et al. 2006). Moreover, a communal decision through the Community Assembly can alter 
common-land usage right, and lands may be sold, or additional land purchased (Castillo and Beilock 2004). This weakness in the regulation allowed foreign investors to grab lands in Santa Elena.

Three leading forms of investment transformed communal lands into private property: a 1970 state irrigation project, the shrimp industry and tourism development. The 1970 state project to construct an irrigation system in Santa Elena sparked sudden interest in buying land that would benefit from the project (Alvarez 1999). Herrera et al. (2006) argue that the unclear legal framework and asymmetry of information regarding the potential of the project favored nonnative individuals to grab rural lands, particularly next to the Chongón-Colonche foothill where a system of canals would bring water from the east. As of 2018, this project was still incomplete despite several governmental efforts. The anti-neoliberal government successfully promoted farming and agriculture in the area while improving a dam's infrastructure, built years before as part of the project.

The shrimp industry introduced the construction of shrimp ponds and shrimplarvae nurseries or laboratorios de larvas in the country. In Santa Elena, this industry developed mainly in Colonche and Chanduy parishes. However, in Manglaralto, shrimp farming also brought communal land dispossession supported by unclear legal procedures. Table \#1 shows current shrimp pond areas in Santa Elena and Manglaralto (GAD-PSE 2015). In Santa Elena Canton, 1.08\% of lands constituted shrimp ponds, while in Manglaralto, this area is small: $0.15 \%$. Additionally, since 1983, the construction of shrimp-larvae nurseries grabbed lands in front of the beaches, which provide extensive amounts of seawater to the processes (PMRC 1993). By the year 2015, 137 shrimp-larvae nurseries operated in Santa Elena, and 33 were inoperative (GAD-PSE 
2015). According to the same resource, six shrimp-larvae nurseries operate in Manglaralto. Interestingly, the Ministry of Agriculture department that is responsible for administering communal lands granted those land concessions (GAD-PSE 2015). Furthermore, legal issues regarding communal land transactions which violated the prohibition to trade common-property lands continue in Santa Elena courtrooms.

Tourism development has been another aspect of land grabbing in Santa Elena. Tourism development in Santa Elena canton includes vacation homes and hotel construction (Leon 2013). For example, the beachfront at the northern comuna of San Jose is full of luxury vacation homes. In Montañita, private investors have built hotels on the beachfront, while the comuneros moved inland, and in Olón, foreign retirees are arriving to occupy recently built resorts.

\begin{tabular}{|l|c|c|c|}
\hline \multicolumn{1}{|c|}{ Shrimp-Industry } & $\begin{array}{c}\text { Santa Elena } \\
\text { Province }\end{array}$ & $\begin{array}{c}\text { Santa Elena } \\
\text { Canton }\end{array}$ & $\begin{array}{c}\text { Manglaralto } \\
\text { Parish }\end{array}$ \\
\hline Shrimp ponds (sq. mi.) & 21.02 & 15.31 & 0.32 \\
\hline Shrimp-larvae nursery (No.) & 170 & 48 & 6 \\
\hline
\end{tabular}

Table 1 Shrimp industry in Santa Elena. Source: Santa Elena Province Development Plan (GAD-PSE 2015)

Thus, territorial issues in Santa Elena reveal comuneros' capacity for rearrangement between the legal interstices introduced after the Law of Communes and the new models of development. In doing so, Alvarez (2002) argues, the Comuneros can preserve power over ethnic territoriality. Indeed, ethnic recognition is still another issue among the Comuneros, as shown in the next section. 


\section{Identity issues in Santa Elena.}

Collective decision-making and communal organization are crucial to confront climatological impacts and territorial challenges without leaving their territory. In this section, I borrow, from Alvarez (2002), the idea that the people of Santa Elena have focused on the concept of land as "the crucial link of cohesion and reproduction of their cultural values" (12) to analyze identity issues the Comuneros confront in their everyday lives.

Alvarez (1999) traces ethnic identification among natives of Santa Elena. In the 1800s, these natives were known as cholos but not as Guancavilcas, the people settling Santa Elena when Spaniards arrived at the area. The cholos of Santa Elena became comuneros after the Ley de Comunas was enacted in 1937. Thus, this term survived the miscegenation during the 1960s and 1970s when the Ecuadorian government pursued the strengthening of a more universal "mestizo" (mixed European and Indigenous) identity throughout the Ecuadorian population. In order to confront the Agrarian Reform enacted in 1964, the natives of Santa Elena joined the Federación de Comunas del Guayas ${ }^{1}$ or Federation of Communes of the Guayas Province, whose primary goal was to defend their territories. ${ }^{1}$

During the 1980s and 1990s, the comuneros were attentive to the ethnicity discourse proliferating in the country, which highlighted the importance of Ecuador's Indigenous populations, countering the state's discourse of a more homogenous, mestizo population. In 1986, the Confederación de Nacionalidades Indígenas del Ecuador

1 The Federation of Comuneros gathered the communes settled throughout the Province of Guayas, to which Santa Elena Canton belonged until the three cantons in the Santa Elena peninsula became a province in 2007. 
(CONAIE) or Confederation of Indigenous Nationalities of Ecuador, was created. CONAIE sought legal recognition for Indigenous peoples and nationalities. It is noteworthy that CONAIE's first Vice-president was a comunero from Santa Elena (Bazurco 2006). In 1987, CONAIE enrolled coastal comuneros, from Santa Elena and Manabí, under the name of Manteño-Guancavilca Town. By the late 1990s, the Indigenous movement in Ecuador had become a more powerful force within national politics (Becker 2011). However, prior to be able to make appeals for ethnicity-based financial or technical assistance, Ecuador's diverse Indigenous groups needed greater levels of legal recognition.

In 2002, the Federation of Comunas in Guayas became Movimiento Indigena Manta-Guancavilcas y Punaes or Indigenous Movement of Peoples Manta-Guancavilcas and Punaes (Tuaza \& Saenz 2014). Ethnic recognition issues did not displace the longstanding federation; instead, Comuneros' association has actively continued its organizational work throughout. In 2004, the Comuneros signed a cooperation agreement with Proyecto de Desarrollo de Pueblos Indígenas y Negros del Ecuador ${ }^{2}$ or Project for Ecuadorian Indigenous People and Afro descendants. The project, funded by the World Bank, aimed to restore the ancestral water system in Santa Elena to address the long-standing water scarcity issue in the region. Santa Elenians received no tangible results through this project. Water scarcity continues to be an important issue in Santa Elena. However, the project's emphasis on providing additional resources to Indigenous

2 This project was part of the World Bank's Indigenous Peoples' Development Initiative in Latin America. 
people promoted local Santa Elenians became more interested in highlighting their indigeneity.

Governmental interventions emphasizing ancestral heritage grew exponentially after 2007 when the government adopted anti-neoliberal state practices. The first and most significant action supported by the left-led government was the creation of the Province of Santa Elena in November 2007. Prior to this, there were several revolts in Santa Elena claiming provincialización, resulting in their separation from the Province of Guayas. While I have spent considerable time examining speeches and other archives, I have not found any records in which Santa Elenians identify themselves as Guancavilcas during that early period. Interestingly, when the leaders called for the union proclaiming provincialism, they use the slogans cholos peninsulares or cholos comuneros.

In contrast, the Ecuadorian government started recognizing Santa Elena's comuneros as Indigenous people starting after the enactment of the new Constitution in the year 2008. The Ecuadorian Constitution in articles about multiculturalism, identifies only three categories of people deserving special provisions: 1) Indigenous peoples; 2) Afro-descendants; and 3) montubios (the identification for inland coastal peasants formalized in 2001). Santa Elena natives are not Afro descendants, nor are they montubios, even though both inhabit the coastal region of Ecuador. Thus, the leftist government categorized Comuneros as Indigenous groups.

Furthermore, the National Plans elaborated under anti-neoliberal practices (SENPLADES 2009, 2013) purposed to strengthen interculturality in the country. In doing so, the leftist government deployed several interventions. In Santa Elena, these included: 
- The Ministry of Tourism switched the name of the tourist route that crosses the province of Santa Elena from "Route of the Sun" to "Route of the Spondylus," in reference to the cultural value of the Spondylus shell.

- Since 2006, the Ministry of Tourism, in conjunction with local governments, has been promoting whale watching as a major tourist draw to the region. The whale watching season starts with an annual parade. While the earliest parades, designed and executed by local people, included mostly the ever-popular clowns and beauty queens because of their popularity among local residents, subsequent parades changed significantly to include more tourist-appreciated components, such as having children display the outfits and rituals of their Guancavilca ancestors.

- In 2011, the Ministry of Culture returned a monolith considered the Guancavilca God of Fertility to the comuna Sacachún. Previously, it had been kept in Guayaquil for 50 years. In the years following, the Ministry of Culture, together with the Ministry of Tourism, planned to develop a tourism product called "The Path of the Guancavilca Gods" to be guided and operated by the local natives, but it was never launched.

- The 2015-2019 Development Plan of the Province of Santa Elena includes among its goals: "to promote cultural expressions of the peninsular society to strengthen the ancestral Guancavilca identity" (GAD-PSE 2015, 73). The document adduces both the census data on self-identification as mestizos, and the lack of cultural promotion, as reasons for losing the local identity and cultural values.

- The municipal government of Santa Elena also promotes the notion of Tierras Ancestrales or ancestral lands throughout the territory. At the entrance, the City Office exhibits replicas of the Valdivian and Las Vegas cultures. Additionally, the 
municipality installed, at the entrance of each rural community, billboards with pre-

Columbian ceramic pictures and a welcoming message accompanied by the slogan “Comuna Ancestral."

In stark contrast to governmental efforts, Indigenous self-identification is almost nil. Interviews with locals and from focus groups I have conducted in Santa Elena reveal the following identity categories to describe Santa Elenians: cholos comuneros, cholos Guancavilcas, cholos pescadores (fishermen) or mestizos. For them, 'Indigenous' means someone from the highlands or Amazonia, rather than being an appropriate term for their ancestral group. However, the comuneros of Santa Elena have a strong attachment to their ancestral lands. It is also noteworthy that they desire to strengthen the symbolic value of their ancestralidad (ancestry) and the defense of their territory. Indeed, people in the comunas of Santa Elena still exist within ambiguous spaces between dominant representations.

Thus, the Comuneros engaged the ongoing political construction of their identity to adapt to new stressors. The analysis has pointed out the interstices of the historical transformation of collective identifications among the natives of Santa Elena. In the neoliberal regime, these coastal communes fostered and forged ethnic identification as a strategy to obtain benefits for their communities. Nevertheless, that strategy did not reach an internal recognition of their indigeneity and thus did not leave any legacy of collective identification. Currently, common identification strategies come from the government, particularly policies associated with the leftist aim of planning everyday lives. Thus, natives of Santa Elena have changed from natives to cholos, from cholos to comuneros, from comuneros to mestizos and finally from mestizos to Guancavilcas, as a strategy to 
acquire resources, assistance, and political participation. The Comuneros focus on their collective identity revitalization while pursuing economic development.

\section{Development issues in Santa Elena.}

When Ecuador reinstated democracy in the 1980s, landscapes in Santa Elena's northern beaches were still pristine. From 1983, the shrimp industry boomed, introducing new developments in the region. In response to the mangrove deterioration that shrimp farming brought to coastal areas, the government signed a ten-year initiative promoted by USAID and implemented by the University of Rhode Island Coastal Resources Center. The initiative created a remarkable program called Coastal Resources Management Program (CRMP). This program operated until the year 2008, when the leftist government merged it with the Ministry of Environment. Chapter 5 details more than twenty years of CRMP operation in the country. It is important for this section to acknowledge that in twenty years of integrated coastal management, the CRMP overcame an unprecedented challenge in Santa Elena, and former CRMP executives and technicians agree that the project achieved sustainable development of the coastal areas of Ecuador

The CRMP's second phase, starting with an IDB operation credit, actively promoted and financed community engagement in local proposals and projects. CRMP's crucial feature was the financial component provided by the villagers: locals collaborated through community service, communal labor, and materials to build their local projects, such as artisan shops, hostels, and restaurants. In doing so, the CRMP achieved the communities' active participation while developing their responsibility and decisionmaking over their entrepreneurship. CRMP also collaborated with NGOs' technical 
assistance. Tuaza and Saenz (2014) identified aid agencies and NGOs providing support in Santa Elena during the neoliberal period in Ecuador (remind us of dates or simply say "prior to 2007"). For instance, the Archdiocese of Guayaquil assisted communities with local initiatives, particularly the weaving of Panama hats. The US-based Plan International improved schools' infrastructure and supported children and teenagers. Fundación Natura (The Nature Foundation), an NGO, promoted Chongón-Colonche forest protection, reforestation, and control of forest clearance with the help of funds from the Canadian bilateral development agency. The Fundación ProPueblo promoted handcrafting with local materials, particularly weaving Panama hats and bamboo cane handicrafts. The Escuela Superior Politécnica del Litoral (ESPOL) or Polytechnic University provided technical assistance on sustainable development, agriculture and water management. The Fundación Ecuatoriana de Desarrollo Social, or the Ecuadorian Foundation for Social Development, mainly focused on women's empowerment. Additionally, the Spanish Agency of International Cooperation promoted the Programa de Ecoturismo Comunitario or Community Ecotourism Project. This project operated through the Ayuda en Acción or Help in Action, a Spanish NGO executing integrated plans of development in Santa Elena, and the Centro de Promoción Rural or Rural Promotion Center (RPC), a local NGO. The primary goal was to develop and strengthen tourism initiatives offered by comuneros. According to David Zambrano (interview with author August 12, 2018), RPC Executive Director, the current community tourism initiatives in Santa Elena have emerged from years of combined efforts between the NGOs mentioned above, the Tourism Ministry, and CRMP. 
Since 2007, a few NGOs have continued working with comuneros, however, the anti-neoliberal rationale denies foreign NGOs' cooperation, financial aid, or technical assistance. The 2008 Constitution and the National Planning Council endorsed the state for having the duty to provide for the wellbeing of the population. Then, the government deployed governmental technical staff to all areas. Additionally, the government directly contracted numerous consultants to assess the existing situation and train locals according to the planned projects, in light of citizens' participation, endogenous development, and the so-called "solidarity economy" enacted in the 2008 Constitution.

The Comuneros found a great ally in the anti-neoliberal rationale of the leftist government, which supported several local projects. For instance, in Corozo, an inland comuna of Santa Elena, the comuneros were proud of harvesting their long- delayed maracuyás (passion fruit) crop, after the Ministry of Agriculture provided technical assistance. Similarly, this occurred with beekeeping in other inland communities, such as Las Balsas or Manantial de Guangala. In the Manglaralto Parish, several communities found an alternative for their cash-strapped economy in community-based tourism, which has been strongly promoted by the state social agenda (El Universo 2007). Communitybased tourism means that revenues from tourism return to the whole community. However, in Santa Elena, community-based tourism refers to small tourist businesses owned and operated by the Comuneros. Paradoxically, family-owned businesses operate in a plot authorized by the Community Assembly, while having the duty of paying a fee to the comuna.

Thus, development has been an additional driving force impacting Comuneros, adding to the climatological, identity and territorial issues in Santa Elena in general, and 
the Manglaralto Parish in particular. Among the thirteen seaside comunas in Manglaralto, Libertador Bolívar is the only one that has not sectioned the land; instead, they have organized themselves to retain their land under communal administration.

Decision-making over territory, identity, and development in Libertador Bolívar

The comuna of Libertador Bolívar occupies 5.54 square miles (14.76 square $\mathrm{km}$ ) from the Pacific Ocean to the interior land (Figure 5). The community has two miles of a wide and rectilinear beach strip, from Playa Bruja at the south all the way north to the river's mouth. The beach at Playa Bruja, the southern area of the village, is banned from tourist development due to the risks caused by the currents. The locally known "south beach" is a tourist area developed at the entrance of the village, where the cliff faces the sea, and where several families manage their hostels, restaurants, and artisan shops. The north beach is next to the mouth of the Atravezado River which crosses the town from east to west. Curiously, the name of this river means "crossed", and Elders in the community assert that the river's ancestral name refers to such crossing.

Indeed, the first geographical study of this area, conducted by Theodore Wolf and published in 1892, documents the river as "Travesao" and also identifies the group of people living next to this river (Wolf 1892, 185). The river mouth forms a hypersaline lagoon (tidal pond), which fills and empties with seawater as the tide rises and falls. However, during the rainy season, the tidal pond can disappear while the river stream floods the area next to the river. Inland, a handful of villagers subsist from small-scale agriculture that is adapted to arid soil and lack of irrigation systems. Agriculture was vital 
at the start of the twentieth century. However, today, tourism has become the main economic activity that supports the entire community development.

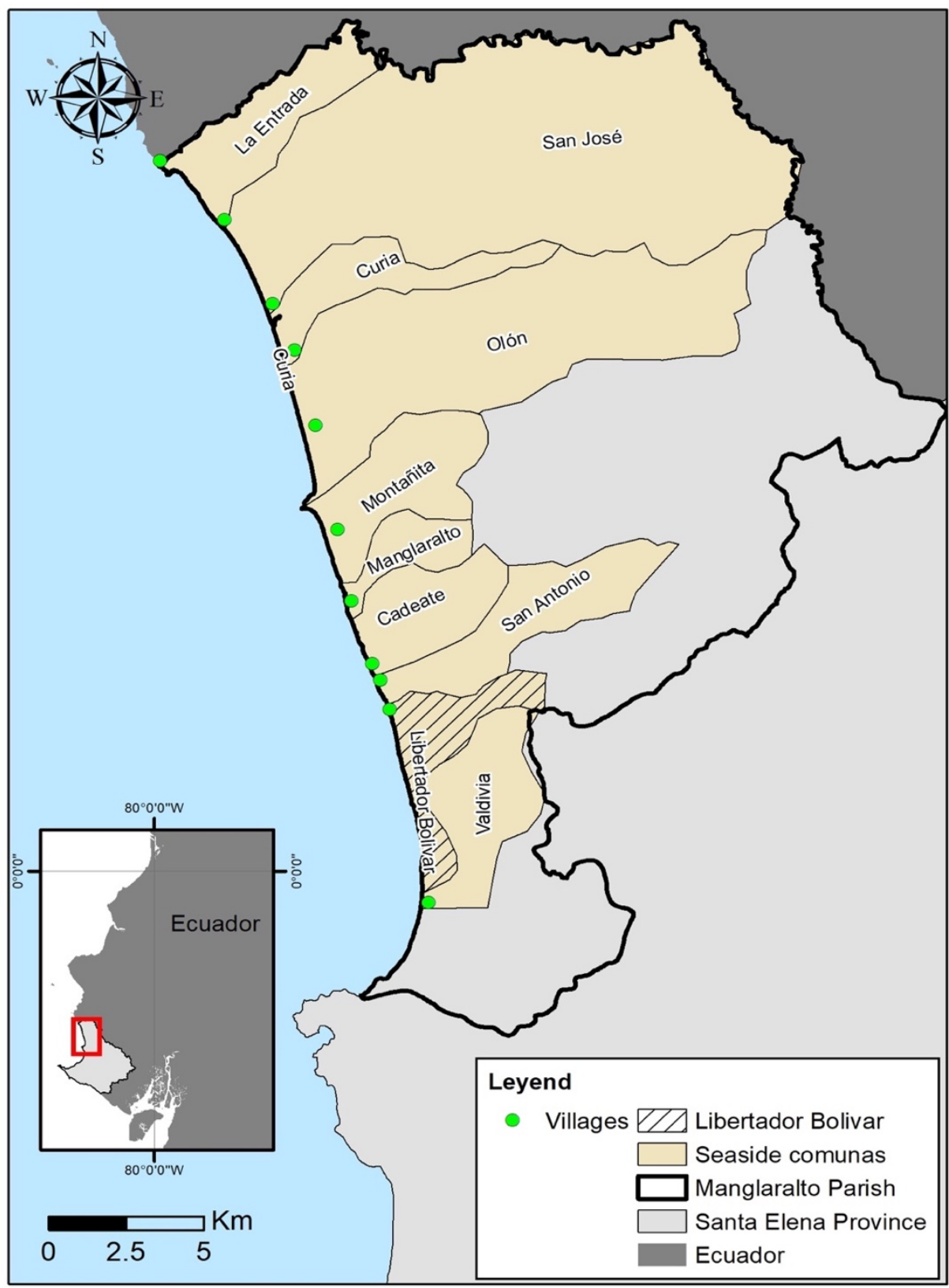

Figure 5. Map of Libertador Bolívar and seaside comunas in Manglaralto Parish. Elaborated by Daniel Garces. Source: 1993 CRMP Development Agenda 
Libertador Bolívar is one of the few communities of Santa Elena that has retained its territory without external investors, despite having confronted attempts of land dispossession. For instance, in 1982, a shrimp farming investor tried to grab the mangrove area in the north of the community. In this event, remembered as La Guerra or The War, Alberto Floreano, a community leader, died in a riot against the intrusion. Floreano conveyed to the comuneros the most ingrained meaning of land defense, an everyday discourse among the inhabitants of Libertador Bolívar. In 2016, I witnessed how the comuneros organized and recovered a plot of land that a foreigner had deceitfully grabbed. Two years later, a juridical resolution decided the case, favoring the community.

According to the records, the Ministry of Agriculture incorporated the community Libertador Bolívar on October 20, 1940, three years after the State issued the Law of the Communes. However, it was in 1970, in response to the Agrarian Reform introduced by the state in 1964, that comuneros in Libertador Bolívar updated the internal regulations and actively started their participation in community development, which came together with the road construction. The road E-15 connects many of Santa Elena's villages to one another, running from south to north, towards the Province of Manabí, among them, Libertador Bolívar.

By the 1980s and 1990s, the primary source of income was the shrimp farming industry. Some of the current community leaders, 40 or 50-year-old men, were larveros or worked at the laboratorios nearby or in other provinces. Although tourism was not the primary source of income, Libertador Bolívar's economy had incidentally engaged in tourism activities. For instance, people from Libertador Bolívar used to sell their products 
at other beaches within Santa Elena, mainly fruits, traditionally baked corn tortillas and handicrafts. Locals I interviewed remember their parents producing crafts made with seashells, including the famous turkey-shaped crafts known as pavitos or little turkeys. Others rented tents on different beaches to shelter tourists from the sun. Several comuneros worked in food and beverage services in communities that had already integrated into the tourist economy, such as Montañita and Olón.

In the early 2000s, locals purposed bringing tourists to their beaches. In the aftermath of 1997-1998 El Niño phenomenon, road construction rebuilt the road in Playa Bruja where some shrimp-larvae nurseries operated. Constructors requested food and beverage services in the community. The comuneros built bohios or cabanas made from gadúa cane to offer their dishes. By the year 2000, some families had built eight cabanas in the southern part of the town. Several NGOs offered Libertador Bolívar financial and technical assistance to improve businesses by providing the minimum infrastructure required for tourism development, such as restroom facilities, lifeguard training, and a tourist information booth. The Ministry of Tourism in agreement with CRMP also provided training in food hygiene, food management, and gastronomy.

Tourism development also generated heated discussions in the Community Assembly regarding land use and rights of any particular family to build the small tourism businesses flourishing in the south beach area. In 2003, the Cabildo issued land possession certificates for those businesses and, in a few years, those huts became a hallmark of Libertador Bolívar's gastronomic offerings, a noteworthy place to visit on the Route of Spondylus (El Universo 2003). As reported by one of the most important national newspapers, traditional dishes, such as the Pescado de la Abuela (Grandma's 
fish), revived by native chefs, are now the flagship of Libertador Bolívar's gastronomic offerings, differentiating the village from other communities engaged in community tourism development (El Universo 2007).

In recent years, this scenario has been replicated on the north beach of Libertador Bolívar, next to the river mouth of the Atravezado River. In communal assemblies during 2013, a handful of community members began to request their right to work on the beach. Later, they built some huts on the north beach, while tourists found a new space for leisure between the river mouth and the sandy beach. Nowadays, the Asociación Rio-Mar or River-Sea Association, has thirteen cabañeros, owners of tourist huts in this area between the sea and the river.

The tourism industry also has revitalized Libertador Bolívar's economy. Fishers, divers, groceries, artisan shops and others depend on the increased income they are able to earn during tourist seasons. A participatory analysis I conducted with a group of Comuneros and officials of COASTMAN, an NGO that has been working in Libertador Bolívar since 2003, shows the evolution of tourism in Libertador Bolívar. Tourist offerings doubled in two decades. By 2017, there were 14 restaurants, 7 hostels, and 1 paragliding tour operator. Unfortunately, most of the tourism businesses in Libertador Bolívar have not been granted Ministry of Tourism certification (see Chapter 6) because they fail to meet all the requirements, mainly regarding security and contingency plans in case of disasters. The municipal office that manages tourist development in the Santa Elena Canton has registered in its official cadaster only one hotel, ten restaurants, and the tour operator. The others operate under legal subterfuge while circumventing risk management and tourism norms. 
The sea and the waves are continually threatening Comuneros' tourist economy at Libertador Bolívar. During fieldwork, I noted the rush the Comuneros experience during the aguaje or high tides coming into the north beach. Each time high tides batter the beach, the comuneros struggle to save their huts and the supplies they need to provide services to the tourists. Every day, Comuneros coexist with the endless threat of waves breaking on the beach, the aguajes, and the rising sea level.

\section{Conclusion: adaptive processes in Santa Elena}

The previous section reveals comuneros' self-determination emerging from their deep attachment to their land. Thus, through communitarian decision-making, Libertador Bolívar has kept foreign investors away from their territory, while comuneros have adapted to the aftermath of ENSO phenomena. This analysis reveals profound changes introduced in the comuneros' economy after the catastrophic phenomenon. While 19821983 ENSO brought the shrimp-larvae economy, the 1997-1998 ENSO introduced the Comuneros to the tourism industry. Comuneros' response to natural disasters has been a process of adaptation to a new socio-ecological relationship on the beaches of Santa Elena. However, the longitudinal analysis also shows the vital role of the State during the decades analyzed by this research. From 1980 through 2007, the Ecuadorian State practiced neoliberal recipes, which promoted coastal resource managerial planning and active local participatory processes while advancing tourism development.

Additionally, neoliberal state practices introduced identity struggles which continue to be a source of uncertainty among the Comuneros. From 2007, the leftist government, adopting an anti-neoliberal rationale, continued revitalizing ethnicity and 
indigeneity, and also promoted an endogenous tourism development which, ultimately, revitalized the local economy. Now, the Comuneros confront new threats. On the one hand, they cannot obtain permits to operate their cabanas legally, and on the other hand, the cabanas on the beach are prone to persistent threats.

Since the beach became the primary resource for the local economy, the sea became a greater threat. However, such a threat is not a catastrophic event compared to the aftermath of disastrous ENSO events. Thus, successive Ecuadorian governments have deployed numerous interventions to mitigate ENSO's aftermath. In the following chapter, I analyze the Ecuadorian governments' concern for disaster and risk management, and the will of the State to improve coastal socio-ecological relations. 


\section{Chapter IV}

\section{Neoliberal and anti-neoliberal risk and disaster management in Ecuador}

Disaster prevention has become crucial in a world increasingly threatened by natural and human-induced hazards. Scholars have successfully disclosed the role of governments integrating human-security concerns and climate risk to national development agendas (Arandau 2014; Brown 2016; Chandler and Reid 2016). Currently, a global key tool for addressing climate and development security concerns is resilience thinking, a hegemonic framework promoted by the United Nations (UN). By 2019, more than one hundred sixty countries are implementing resilience policies as a solution for environmental and societal security. The UN Disaster and Risk Reduction framework entails a systematic enhancing of national and local capabilities to manage and reduce risk. Accordingly, by increasing resilience, populations will be less vulnerable to disasters of any kind. The analysis of the effects of policies aiming to building resilience have disclosed resilience programs pervading individuals through governmental circulatory power tactics (Anderson 2010; Dunn et al. 2015; Davoudi and Madanipour 2015; Grove 2013b). Thus, resilience has become an art of governing the population which creates a series of truths under the vision that life needs to be secured.

In this chapter, I trace how disaster management in Ecuador ordered relationships among population, development, and risk. From the 1980s to early 2000s, Ecuadorian governments adopted and adapted the practices of neoliberal states, and from 2007 to 2017, the government adopted left-led state practices. My goal is to critically reflect on 
the intimate relations and interconnections of neoliberal and anti-neoliberal approaches to disaster management by focusing on how the Ecuadorian governments spatialized disaster through social and non-social strategies and techniques deployed through the country in general, and coastal areas in particular. The chapter excavates global, regional, and national discourses emphasizing technocratic management of experts, which, ultimately, ordered a new relationship between population, development, and risk in the rural areas of Santa Elena. In the first section of this chapter, I analyze the neoliberal concern for catastrophes in Ecuador and its connections with the modernization of the state. The second section traces the emergence of a culture of risk during the anti-neoliberal government ruling Ecuador. The chapter concludes by comparing the logics and mechanisms that both types of Ecuadorian government have developed for securing the population.

\section{The neoliberal concern surrounding disasters in Ecuador}

During the last decade of the twentieth century, numerous natural catastrophes significantly impacted Ecuador's economy. In 1993, a landslide damaged La Josefina dam in the southern region, followed by the Nambija mine disaster in the southwest of the country. In 1994 and again in 1996, forests on the Galapagos Islands burned. Earthquakes occurred in Morona Santiago (Amazonia) in 1995, Pujilí (Andes) and Bahía de Caráquez (Coast) in 1996. Between 1997 and 1998, the El Niño climate phenomenon devastated the Ecuadorian coast and other regions in the Amazonia. During 1998-1999, the Pichincha Volcano, near the capital city of Quito, erupted several times. Another earthquake wreaked havoc in the north of the province of Manabí in 1998. The 
Tungurahua Volcano erupted in 1999. In addition to this series of diverse natural disasters, in 1995, Ecuador engaged in a two-month military conflict with Peru (Guerra del Cenepa or The Cenepa War), by the end of which both countries achieved a longdesired peace agreement.

Furthermore, such crises coincided with governmental instability. From the 1980s onward, Ecuador reinstated democracy, with influence from US-based international agencies promoting neoliberal practices in Latin America. From 1996 to 2006, political instability deepened in Ecuador, when seven presidents got the office after democratic elections, impeachments, or resignations. In this section, I trace disaster management governance during those years of unrest, deeply permeated by neoliberal state practices. According to Rebotier (2016), governmental decisions addressing disaster management in Ecuador followed Latin American's major paradigmatic stages and politicalinstitutional frameworks of risk management. Nowadays, Latin American countries posit risk as a problem of development and as a social matter. However, originally, those countries organized disaster management toward response and reconstruction, mainly through the Civil Defense.

\section{Dimensions of the Ecuadorian Civil Defense}

Ecuador started to approach the field of disaster management in November 1960 by issuing the National Defense Law, which defines the role of the state in terms of forecasting and reducing potential impacts of disasters and includes the first legal normative regarding Civil Defense. However, it was in 1972 that the government created the Civil Defense together with the Secretariat of the National Committee for Civil 
Defense. In 1979, Ecuador adopted a new National Security Law Nº 275/79, which created a National Civil Defense System, led by the General Secretariat of the National Security Council. The National Institute of Civil Defense, the National Direction of Mobilization, the National Intelligence, and the High-Studies National Institute comprise the NCDS. During the 1980s, the Consejo Nacional Permanente de Seguridad Nacional or National Permanent Council of National Security regulated the National Civil Defense System (Carrion et al. 2017), highly focused on relief, while public policy missed disaster prevention or reduction.

After a decade, the government issued the complementary regulation of the 1979 law. In Article 75, the regulation defines Civil Defense:

"Civil Defense is a state activity of permanent service favoring the community, reached through the System of Civil Defense, responsible for planning, organizing and using personal, sources and services to prevent, avoid, reduce, and repair the effects of catastrophes of any origin" (emphasis added).

Additionally, the National System of Civil Defense roles should, among others, "[d]etermine the areas potentially exposed to disasters and carry out preventive information campaigns" (Art. 87). However, most of the articles in both the law and the regulation refer to the post-disaster intervention: damage assessment, emergency rehabilitation, reconstruction. Prevention in practice was absent. Indeed, some former CD volunteers, currently Risk Management officials, agree on the legal gaps reducing the CD's capacity to address prevention. On the contrary, the CD worked reactively, claim 
former $\mathrm{CD}$ volunteers. For instance, "the $\mathrm{CD}$ prepared volunteers to respond to emergencies and disasters, but did little or no work on prevention issues," explains a current Risk Management official and former CD volunteer in Santa Elena (E1, interview with author June 6, 2018).

Disasters and the modernization of the state

With the arrival of a newly elected president to office in 1992, criteria on national development integrated with environmental arguments and decentralization illuminated Ecuadorian modernization of the state. In 1993, the state issued the Law of Modernization of the State, Privatization, and Provision for Public Services by the Private Initiative, simply known as Law 50, which has been highly criticized by the deepening neoliberal state practice in Ecuador. Mainly, the law promoted state decentralization with a strong privatizing component (Rebotier 2016). In the following paragraphs I describe two main factors influencing disaster management and risk approaches during the modernization of the State.

Firstly, in 1995 the National Congress created the Fondo de Solidaridad or Solidarity Fund. This autonomous body aimed to alleviate poverty in rural areas, by managing energy and telecommunication for state companies - a neoliberal practice to de-regularize state functioning. El Fondo, as it was popularly known in Ecuador, will exclusively finance education, health, and environmental sanitation programs in rural areas, as well as the social effects of natural disasters. The first application of such funds financed the post-war conflict expenses in the mid-1990s, due to border problems between Ecuador and Peru. Overall, the Fondo de Solidaridad mainly financed sanitary 
infrastructure projects (sewerage, potable water, residual waste treatment), health and education programs, and mitigation efforts in marginal sectors of the country, by contracting private providers.

Secondly, the Development Agenda 1993-1996 (CONADES 1996) summarizes policies and governmental objectives towards state modernization. The agenda highlights the environmental deterioration, and the mismanagement of natural resources that threatened the country's sustainable development. According to this official document, Ecuador would achieve sustainable development "only when its three elements: the social, the economic, and the environmental are treated in harmonic and balanced ways" (CONADES 1996, no pagination). Thus, environmental approaches became a pivot for the development of the country.

The Development Agenda's environmental concern dedicated a section titled "High risk of the country to natural and anthropic disasters" (CONADES 1996, 61-65). The section summarizes various data on the population risk, prone to natural disasters. For instance, the agenda highlights that $80 \%$ of the population were prone to seismic disasters and $35 \%$ of the population settled in areas prone to flooding, landslides, mudflows, and debris. The Agenda includes tsunami and ENSO-related events directly threatening $10 \%$ of the population inhabiting the coastline. More importantly, the agenda reveals an inadequate regulation of disaster management. Overall, the document reveals an absence of policies related to disaster prevention and mitigation, an outdated legal framework, inadequate norms for construction, low budgetary allocation, population settled in highly vulnerable zones, and erosion of hydrographic basins. The agenda 
concludes by revealing a lack of political decision regarding disaster-related solutions in the country.

The 1996 Ecuadorian Development Agenda also brought technical identification of high-risk areas into focus and the need for developing risk prevention policies. Consequently, the agenda aims to "incorporate into the national, regional and local planning systems the risk variable as a development concept" (CONADES 1996, 64). In doing so, the government allocated funds for technical departments engaged with disaster prevention and also opened the Civil Defense's scope of action through the creation of a specialized force within the Army. Additionally, risk and environmental impact evaluations became a new section in all private or public development projects.

Nevertheless, neither the Development Agenda nor the Fondo de Solidaridad achieved a legal framework towards disaster prevention, according to the Ecuadorian UN assessment of the Decade of Disaster report (Burbano 1998). In said report, submitted to the UNDRR in 1998, Gustavo Burbano, then-Civil Defense Director, details the actions to disaster prevention in response to the natural catastrophes that occurred in the decade of the 1990s. The report acknowledges the lack of action in disaster mitigation despite including the risk variable in the national development plan. The report also contains information on training programs executed particularly among authorities, implementation of evacuation drills, and a few contingency plans.

However, the CD Director revealed that risk awareness was still absent among citizens who continued to rely on the criterion "God must not allow these evils to reach them," handwrites Burbano. Furthermore, the report mentions the weakness of Civil Defense in implementing regulations on land use, water management, reforestation, 
construction norms, and others. It was challenging to achieve since the Civil Defense's scope of action addressed post-disaster intervention, argues CD Director. Finally, the report denounces scattered disaster prevention regulations among state agencies, municipalities or local institutions.

Rebotier (2016) also reveals the lack of accomplishment on disaster reduction during the International Decade for Disaster Reduction. Rebotier points out the lack of resources and roles dispersion among different entities. Accordingly, the publication Ecuador Lessons from El Niño 97-98 (CAF 1998), an institutional description of Ecuador in the face of disasters, reveals that prevention and mitigation "do not have an institutional system for risk management," and, "the existing norm does not internalize the concept of risk management" (CAF 1998, 239-240). Furthermore, the document highlights the "nonexistence" of policies for prevention or reduction of vulnerabilities and damage caused by natural disasters, not even for the agricultural sector and its production system (CAF 1998, 240). Additionally, the document discloses the reactive response the Ecuadorian governments has had in the face of natural and anthropic disasters.

In sum, the 1990s imprinted a concern over the country's propensity to deal with natural and anthropic disasters, the need of managing funds, and the inclusion of environmental issues on development agendas. Additionally, the UN Decade of Risk Reduction in Ecuador failed to introduce prevention criteria. Instead, scattered initiatives on risk were disseminated through development goals, while the Civil Defense organized natural disaster relief and recovery. In the dawn of the new century, the legal framework 
on disaster prevention and mitigation continued to be absent in neoliberal regimes ruling Ecuador.

\section{ENSO lessons in Ecuadorian disaster management}

ENSO management during the years 1997-1998 instantiates the dispersed roles in Ecuadorian disaster management, and the government's reactive response when coping with a natural disaster. El Niño Southern Oscillation (ENSO) is a very complex anomaly which includes changes in the oceanographic and the atmospheric systems, with worldwide consequences in different levels and different seasons. During average years, in the coast of Ecuador (and Peru) the strong southeast trade winds blow the warm surface waters, producing an abundant supply of food for small fish, providing a good living for fishers (Robbins et al 2014). However, during El Niño-Southern Oscillation (ENSO) phenomenon, trade winds fade for some months. Later, trade winds start to push the warm surface water again, returning to normality. Specialists agree that this hydrometeorological phenomenon does not repeat at regular intervals and its intensity is also variable. ENSO causes extreme increases in the volume of rain and swells, consequently causing floods, mudslides, dike breaks, etc., and disturbing human lives and productive systems.

The event that occurred between 1997-1998 has been the phenomena with the most profound impacts on Ecuador. ENSO 1997-1998 flooded 6,381.3 square miles $(16,527.6 \mathrm{~km} 2)$, that is to say, $6 \%$ of the Ecuadorian territory, mostly in the coastal provinces (Gasparri et al., 1999). This event has been well documented by scholars and informed through technical working papers. However, the most relevant document, according to the literature, is the report issued in 1998 by the UN Economic Commission 
for Latin America and the Caribbean ${ }^{3}$. According to the UN commission's evaluation of the socio-economic effects of ENSO 1997-1998, damages totaled US\$2,869.3 million (\$486.4 million for post-disaster rehabilitation and \$1,589.1 million reconstruction) (CAF 1998). A World Health Organization report (OPS 2000) records total damages equaling $17 \%$ of Ecuadorian GDP. The same report reveals that more than 15,000 homes were damaged in rural areas, producing migration to the big cities. In addition, 6,276 severely affected families lost homes and belongings, and had to live in shelters, with their relatives or with friends. Between October 1997 through June 1998, 292 people died by causes related to ENSO; 162 people were injured and 40 disappeared (OPS 2000). Additionally, Gasparri et al. (1999) estimate that the shrimp industry lost $\$ 3.5$ million while shrimp pond reconstruction cost US\$4 million.

International alerts announced ENSO's impact in December 1996 and January 1997 (OPS 2000, CAF 1998). However, the country did not promptly take any political action to prevent the disaster caused by ENSO. It is noteworthy that Ecuador again faced a political upheaval which intensified in January 1997. The democratically elected president stepped down, and an interim president ruled Ecuador from February 1997 to August 1998. A national emergency was declared in July 1997, after which the Ecuadorian government partnered with the European Commission for Humanitarian Assistance and Protection and other international NGOs already operating in the country. In September 1997, the Ministry of Public Health planned and executed a mitigation plan, which included vaccination, medical supplies acquisition, and contingency plans at

\footnotetext{
${ }^{3}$ Under an agreement between the Government of Ecuador and the Corporacion Andina de Fomento (CAF) or Andean Development Corporation - Development Bank of Latin America (ECLAC 1998).
} 
local and provincial levels. However, according to the OPS report (2000,179-180), those previous actions did not have the required strength and continuity, mainly because of the lack of permanent financial resources in the Ministry of Public Health's regular budget. Therefore, the World Bank authorized US\$8 million to the Health Contingency Plan to confront ENSO.

In October 1997, the interim president created the Unidad Coordinadora del Programa de Emergencia para Afrontar el Fenomeno El Niño (COPEFEN) or Coordination Unit of the Program to Confront El Niño Phenomena. COPEFEN's primary role was to operationalize the contingency plan the government elaborated to confront ENSO aftermath by financing prevention and rehabilitation works ${ }^{4}$. COPEFEN was "the recipient of the funds lent by the multilateral institutions for reconstruction projects" (Solberg et al. 2003, 14). However, a "clear" definition of how to distribute the resources provided by IDB, World Bank, and other international donors was absent (Gasparri et al. 1999).

In July 1998, Ecuador also created the Corporación Ejecutiva para la Reconstrucción de Zonas Afectadas por el Fenómeno del Niño (CORPECUADOR) or the Executive Corporation for the Reconstruction of Zones Affected by the El Niño Phenomena. CORPECUADOR would receive money from national incomes to "directly and autonomously" define, design, contract, and monitor the reconstruction projects (Solberg et al. 2003,10) $)^{5}$ Three main national incomes will finance this entity: $0.7 \%$ of

\footnotetext{
${ }^{4}$ In 2002, COPEFEN expanded its competences to confront all kind of disasters, not only the ENSO aftermath.

${ }^{5}$ In the year 2006 CORPECUADOR managed roughly US\$50 million per year
} 
banana exports, $25 \%$ of Fondo de Solidaridad profits, and $10 \%$ of the increment of State participation of oil sales (Official Record \# 378, issued on August 7, 1998). Both organizations CORPECUADOR and COPEFEN concentrated large amounts of money, while some national ministries weakened (Solberg et al. 2003).

In sum, the main criteria for providing public welfare in ENSO's aftermath were the abundant reconstruction works in the entire country, while policies addressing disaster prevention and post-disaster management were absent. Additionally, the government only undertook disaster relief actions starting in July 1997, even though ENSO had already impacted the country since the beginning of the year. D'Ercole \& Trujillo $(2003,113)$ argue that Ecuadorian authorities acted late because of the "lack of enough criteria to discriminate between types of risk and, consequently, to identify vulnerabilities." Similarly, the 1998 report (CAF 1998) denounces that those policies regarding disaster management did not internalize the meaning of risk management, neither did it discriminate between vulnerability and risk.

At the international level, the ENSO 1997-1998 aftermath paved the way to address disasters in Latin America. The extensive damage ENSO caused aroused concern among the Presidents of the Comunidad Andina de Naciones or Andean Community of Nations: Ecuador, Peru, Bolivia, Colombia, and Venezuela. By 2000, the Andean community created the Andean Regional Program for Prevention and Disaster Risk Reduction. The regional initiative fostered disaster management planning among the Andean countries in the following years. 


\section{Disaster management going into the twenty-first century}

At the start of the twenty first century, initiatives on disaster management flourished on the national agenda in response to the series of natural disasters the previous decade imprinted on Ecuador. By January 2000, the country struggled again with political turmoil and reached the most profound economic crisis. Another democratically-elected president resigned in the middle of a strong coup and the VicePresident took power. In 2001, the National Planning Office and the Ministry of Environment issued the National Program for Natural Disasters Prevention and Risk Management in Ecuador, under the UN Disaster and Risk Reduction program and the Andean regional initiative umbrella (ODEPLAN 2001). The program aimed to systematize disaster management by targeting prevention, monitoring, inter-institutional articulation, and financial investment for disaster mitigation. An overarching criterion on enhancing local capacities infused the program, including the study of vulnerabilities and risks. However, Solberg et al. (2003) critique the political weakness the Ecuadorian planning office had to enhance risk management in the country since the Office was created by a Vice-president's decree, without Congressional endorsement.

Meanwhile, international NGOs continued dispersedly operating in the country. For instance, COOPI and OXFAM, European humanitarian NGOs, compiled the first systematization of information related to risk in Ecuador by creating natural hazard maps by each canton in Ecuador (Demoraes \& D'Ercole 2001). The document became central to subsequent disaster management policymaking. However, the report notes, "phenomena whose extension is mainly local (frosts, gales, hail, forest fires, salinization

of land) were not taken into account" (Demoraes \& D'Ercole 2001, 4) in the analysis, the 
report states. Similarly, CORPECUADOR organized workshops to confront ENSO's impacts. The workshops aimed to raise awareness of citizens regarding garbage disposal, settlements in hazardous sites, and "to adopt a culture of risk prevention," (E1 Universo 2002). In early 2007, the Coastal Resources Management Program delivered to the coastal municipalities and provincial councils 172 geological maps, which became a baseline for infrastructure development (Victor Osorio, Former CRMP Executive Director, interview with author July 11, 2018).

At the international level, Ecuador continued to actively participate in the Andean group and its prevention program. In 2002, the Andean initiative created the Comité Andino para la Prevención y Reducción de Riesgos de Desastres or Andean Committee for Prevention and Reduction of Risk Disasters (Andean Decision \# 529). This committee, comprising regional representatives in charge of disaster management in their countries, realized on a polarized functioning and dispersed responsibilities managing disasters in the region. Thus, the committee's primary goal was:

"To contribute to risk reduction and natural and anthropic disaster impacts that may occur in the territory of the Andean Subregion, through policies of coordination and promotion, strategies and plans, and the promotion of activities in prevention, mitigation, disaster preparedness, rehabilitation and reconstruction, as well as through cooperation and mutual assistance and the exchange of experiences in the field" (CAN 2002, no pagination).

In 2003, the European Commission and Andean group signed a financial agreement by which the Proyecto Apoyo a la Prevención de Desastres en la Comunidad 
Andina or Project for Supporting Disaster Prevention in the Andean Community would contribute to vulnerability reduction and sustainable development promotion from 20052009. Rebotier (2016), who traces Andean countries' efforts on disaster management, argues that said program would escort Andean countries toward risk management, emphasizing the anticipatory configuration of the risk, integrated to the development process and territorial planning. The regional initiatives resulted in conceptualizations on risk that "progressively" reconfigured the system toward integrated risk management, "connected with the ordering of space and the country's development" (Rebotier 2016, 46).

Since their inception, regional efforts in the Andean countries have consistently coordinated strategies with the United Nations Agency for Disaster Risk Reduction (UNDRR) in the institutionalization of risk management. Those strategies mainly included the Hyogo Action framework, an initiative to reduce disaster risk adopted by the UN member states in 2005. This framework is a policy goal for the international disaster management community designed to increase communities' response, resilience, and adaptive capacities. According to Grove (2013a), resilience building was formally institutionalized in disaster management, through such hegemonic framework. The next section reveals an anti-neoliberal adoption of $\mathrm{UN}$ initiatives on disaster and risk management.

\section{Anti-neoliberal resilience and a culture of risk in Ecuador}

The Ecuadorian government implemented anti-neoliberal state practices from January 15, 2007, when a left-led movement constitutionally obtained the Presidential 
Office. Contrary to neoliberal de-regulation of state, the leftist government increased the regulatory functioning while implementing national planning of collective life (See chapter 3). According to De La Torre (2010), the leftist government aimed to plan collective life elements in the country by radically changing the whole national legal framework. Indeed, in a few years, the leftist government completely transformed the state's administration, by enacting a new constitution and a plethora of laws, regulations, and programs. In this section, I unpack the machinery assembling legal frameworks and local programs that created a culture of risk in Ecuador in general, and in the coastal province of Santa Elena in particular. I argue that hegemonic frameworks to manage risk and disaster pervaded the anti-neoliberal practices in Ecuador.

\section{Adoption of international frameworks of resilience since 2007}

According to Maria del Pilar Cornejo, the former Risk Management Secretary, the criteria underpinning RMS in Ecuador were the Hyogo and Sendai Frameworks, which promote locals' resilience-enhancing. Furthermore, Ecuador became part of the UNDRR National Platforms for Disaster Risk Reduction, by which countries share disaster and risk best practices at global and regional levels to improve the Hyogo Framework of Action (UNDRR 2019). Similarly, several official documents reveal that RMS's primary goal was to increase resilience. For instance, a country document RMS issued in 2012, asserts:

"The shift in approach that the National Decentralized Risk Management System has implemented, moving from a response to an integrated logic, presupposes substantial progress that should gradually result in a better 
understanding of the process for disaster risk reduction and the increase of resilience" (SNGR 2012, 22).

Similarly, reports RMS issued and submitted to the UNDRR highlight resilience as a country's crucial strategy and goal (MRE 2009; MRE 2011; SNGR 2013). The criteria of resilience spread to the local levels through national or local plans, for instance, Santa Elena's Flooding Contingency Plan issued in 2009 (GADMSE 2009). One of the main goals of the plan is to increase resilience of urban areas in Santa Elena Canton. Interestingly, the plan includes a definition of resilience based on UNDRR frameworks:

"The capacity of a system, community or society potentially exposed to threats to adapt, resist or change in order to reach and maintain an acceptable level of functioning and structure. It is determined by the degree to which the social system can self-organize to increase its capacity for learning about past disasters in order to achieve better protection and improve disaster risk reduction measures." (GADM Santa Elena 2009, 183).

Overall, as I show in the following sections, the UN definition of resilience as the capacity to resist, respond and recover from disturbing events has been the criterion for traversing RMS in Ecuador. Thus, RMS' logic of prevention aims to mitigate potential disasters by building both infrastructure and a culture of risk throughout the country.

The anti-neoliberal integrated logic of resilience building

Since entering office in 2007, the leftist government intensely criticized the neoliberal technocracy managing disasters in Ecuador. Rejecting neoliberal experts' 
policymaking, the anti-neoliberal discourse aimed to incorporate "actors historically excluded from the logic of the capitalist market" (SENPLADES 2009, 10). Moreover, the anti-neoliberal practice in Ecuador aimed at a society that participates in all levels of the national administration. Thus, national planning promoted a vision towards the potentiation of human capacities by the active integration of members of society in policymaking (SENPLADES 2009). Consequently, the main criteria underpinning antineoliberal state practices in Ecuador aimed to enhance the society, "not the market (as in neoliberalism), nor the State (as in the so-called "real socialism")" (SENPLADES 2007, 45). In this way, the State should address a planned and participatory intervention to the most remote hamlet in the country.

National planning also incorporated a risk management system in Ecuadorian society, through an integrated logic to manage disaster and risk (SENPLADES 2007). The integrated logic included raising population awareness of threats, a transversal inclusion of risk management intersecting development planning, and creating monitoring systems. Firstly, the government undertook a reorganization of the National Council of Security and the Civil Defense, particularly because disaster prevention and prediction were not their institutional priority. In 2008, the government created the Secretaría Técnica de Riesgo or the Technical Secretariat of Risk, a national office responsible for managing disasters in the country (Decree 1046-A), which later became the Risk Management Secretariat. The National Council of Security and the CD merged into the new national office, after which all former Civil Defense officeholders and volunteers merged with the RMS. 
Since the creation of RMS, three main areas underpinned its administration: Technical, Social and Response. The scope of the Technical Area aimed to identify and reduce risk by generating technical inputs (geological, hydrological, and so on) toward risk reduction policy. The Social Area addressed enhancing or strengthening capacities throughout the country. Social construction is the area "by which risk management extended across Ecuadorians' everyday lives," asserts Enrique Ponce, former Risk Management Coordinator in Santa Elena (interview with author August 30, 2018). The Response Area operates particularly for disaster relief - this was the most notable area during red or orange codes (levels of threats and disasters).

According to the 2008 Constitution, protection of the population must encompass all levels: education, healthcare, social security, habitat and housing, culture, leisure, communication and freedom of expression, scientific and traditional knowledge, and risk management. In this sense, risk management became a national policy, critical in the national system to address social welfare. The policy was embedded with an integrated logic of prevention, preparedness and vulnerability reduction. Article 389 states:

"The State shall protect persons, communities and nature against the adverse impacts of natural or human-made disasters by risk prevention, disaster mitigation, restoration and improvement of social, economic and environmental conditions, to minimize the condition of vulnerability."

Article 389 also outlines the primary duties of the technical body guiding risk management:

- to identify existing, potential, external or internal risks,

- to create and communicate timely access to manage risk, 
- mandatory incorporation of risk management in public and private spheres,

- to build up capacities to identify and address risk and vulnerability reduction,

- timely provision of funds to warrant the risk management system proper functioning at national and local levels.

Thus, Article 389 aims to create a culture of risk in Ecuador through a logic centered in notions of preparedness and vulnerability reduction, pervading the whole country to secure Ecuadorians. Article 390 suggests that the government will achieve this through the principle of subsidiary decentralization (See chapter 3), a de-concentration of competences by which the national government transfers to local governments the responsibility for administering social, ecological and economic arrangements. Thus, all territorial regimes must organize their territory by planning their development agenda as well as their territorial ordering. Such agenda should include risk management criteria according to the different levels of governance stipulated in the constitution. As shown in Table 2, risk management constitutionally permeated all levels of governance.

The 2009 national plan also addresses the country's vulnerability to natural and anthropic threats. In response, a logic of prevention permeated the anti-neoliberal rationale for reducing environmental vulnerability. Thus, adequate planning and development of land use management can prevent many disasters. Additionally, prevention must strengthen "the capacities of different actors that can intervene in crisis prevention of natural disasters, and so on" (SENPLADES 2009, 101). The criterion was to "protect the environment and evaluate the risks of the natural disaster by taking precautions and implementing mitigation measures" (SENPLADES 2009, 67). In Section 8, the plan also includes a section titled "Integral management and risk reduction" in 
which the national plan reveals the importance of transversally incorporating the risk variable in the planning and implementation of all public works. In doing so, the plan aimed to reduce population and infrastructural vulnerability. However, this new logic of managing and preventing risk in Ecuador required additional changes to the Ecuadorian legal framework.

\begin{tabular}{|l|l|}
\hline $\begin{array}{c}\text { Autonomous and } \\
\text { Decentralized } \\
\text { Governments }\end{array}$ & \multicolumn{1}{|c|}{ Risk Management Scope (2008 Constitution) } \\
\hline National & $\begin{array}{l}\text { Article 261 item 8: Exclusive competence on disaster } \\
\text { management. }\end{array}$ \\
\hline Provincial & $\begin{array}{l}\text { Article 263 item 3: To execute works in river basins and } \\
\text { micro-basins. }\end{array}$ \\
\hline $\begin{array}{l}\text { Municipalities } \\
\text { (Cantons) }\end{array}$ & $\begin{array}{l}\text { Article 264: } \\
\text { Item 10: Delimit, regulate, authorize and control the use of } \\
\text { sea beaches, riverbanks and riverbeds, lakes and lagoons, } \\
\text { without prejudice to the limitations established by law. } \\
\text { Item 13: Manage prevention services, protection, relief and } \\
\text { fire extinction. }\end{array}$ \\
\hline Parrish & $\begin{array}{l}\text { Article 267: Only in coordination with upper levels of } \\
\text { governance. }\end{array}$ \\
\hline
\end{tabular}

Table 2. Risk Management Roles De-concentration. Elaborated by author. Source: 2008 Ecuadorian Constitution

Thus, the leftist government issued the Law of Public and State Security (O.R. \# 35 , Sept 28, 2009) which mentions risk prevention among the principles of public and state security (Art. 4). Additionally, the law transferred the National Council of Security into the Ministry of Security Coordination and upgraded the RMS to the rank of a ministry. Thus, the Technical Secretary of Risk Management became the National 
Secretary of Risk Management (Executive Decree \#42, Oct 20, 2009). Later, CORPECUADOR, the institutional body created for reconstructing zones damaged by ENSO 1997-1998, merged with the RMS (Executive Decree \# 208, January 07, 2010). In September 2010, the Executive Decree \#486 updated RMS regulations. This decree connects risk management with the constitutional subsidiary principle, explained above. On the one hand, the decree's Article 26 states RMS's responsibility for training officials, community leaders, and the general population to developing skills on prevention, risk reduction, and mitigation. On the other hand, Article 19 stipulates Risk Management System decentralization and transversality:

"The National Decentralized System of Risk Management is compound[ed] by the Units of Risk Management of all public and private institutions in the local, regional and national levels" (emphasis added).

In sum, the Ecuadorian government had the responsibility and the duty of securing the population and worked to expand RMS to all levels of societal interrelation (public or private). As Ecuador's then-Minister of Defense Maria Fernanda Espinoza stated during the opening session of the 4th Regional Platform for Disaster Risk Reduction in the Americas: risk management must shift from national policy to a local practice under the logic of risk.

"No disaster is a natural phenomenon. If it were, it would be inevitable.

Disasters in most cases are the result of human error or ignorance. That is why the management of risk is our responsibility." (UNISDR-SGR 2014, 38) Under this governmental rationale of risk management responsibility, a culture of risk emerged in the country. According to the new legal framework, public and private 
institutions were required to organize risk management units. The next section documents how the leftist government mobilized disaster and risk management to the most remote settlement and individuals in the country in the following years, and thereby, a culture of risk pervaded Ecuador.

The anti-neoliberal risk management machinery pervading Ecuadorians lives

The legal framework on security introduced by the anti-neoliberal governmental ruling Ecuador since 2007, demanded risk management intervention in all levels of collective life. The National Decentralized Risk Management System ensembled a governmental machinery which normalized a culture of risk in the whole country. In this section, I show how the governmental machinery traversed local governments under risk reduction, mitigation, and resilience enhancing criteria.

Risk management mandatorily spread through local levels of governance, after issuing the Código Orgánico de Organización Territorial, Autonomía y Descentralización or Organic Code for Territorial Organization, Autonomy and Decentralization (CTOAD), in October 2010. Mainly, the regulation focuses on territorial management under the subsidiary principle (Art. 390, 2008 Constitution): decentralization and de-concentration of functions. Overall, CTOAD describes roles, functions, and responsibilities of every type of ADGs: Regional, Special Regimes, Prefecture, Municipality, and Parish levels. According to the law, municipal ADGs have exclusive control over territorial ordering, land use, and disaster risk reduction. As a result of this law, municipal administrations directly assumed risk management as one of several functions. Specifically, Article 140 transfers natural or anthropic threat 
management to municipal administration, however, policies, plans, strategies, programs, communication supplies, etc. remain RMS's responsibility. Thus, by law, risk management shifted from the national to the local level. However, this new arrangement of local administration was not only an issue of adopting a territorial organization, but the lack of municipal budget complicated the de-concentration of risk management.

RMS tackled the financial concern by introducing the Risk Management Financing Program, in agreement with Banco del Estado (BEDE), a state bank that funds development programs. Overall, the program funded municipalities to build mitigation and prevention infrastructure by subsidizing $50 \%$ of the investment. The funding priorities were preventing natural or anthropic impacts by building infrastructure, such as water systems, sewer systems, road systems, and seawalls to protect beach erosion, retaining walls to define riverbeds, and other related work toward risk mitigation. Under RMS approval, BEDE distributed funds throughout all provinces in Ecuador.

Simultaneously, RMS addressed ADGs regulatory gaps by implementing the Vulnerability and Disaster Risk Reduction Estimation project at the municipal level. The program, sponsored by the UN Development Program and the European Commission of Humanitarian Aid Disaster Preparedness Program (DIPECHO), aimed to estimate socioeconomic, political, legal and institutional vulnerabilities of municipalities. Thus, during 2010-2011, RMS analyzed 1) socio-economic vulnerabilities, 2) decision-making autonomy of each community and the possibility of creating and implementing risk management actions under such autonomy, 3) municipal ordinances regarding risk regulations, and 4) how municipalities were administering risk management following locals' everyday activities. Project outcomes are preliminary cartography on vulnerability, 
statistical analyses, and recommendations for future implementation — inputs for risk management units at the municipal level. Ultimately, the DIPECHO-sponsored project designed a methodology that allows municipalities to coordinate development and territorial ordering, including decisions on disaster risk reduction (SNGR 2013).

Three main areas operationalized RMS's transversal scope: Technical, Social, and Response. They are not, specifically, an organizational chart of the secretary. Instead, the areas act as an umbrella for the administrative organization of the national secretary. Thus, the technical area generates inputs for risk reduction. The identification of risk and vulnerabilities joins a multidisciplinary technical group (experts in geology, hydrology, oceanography, among others) to identify risk, vulnerabilities, threats, and so on. The second RMS' range of activity is the social area, also known as Enhancing Capabilities area, which comprises all levels of collective life, by addressing participatory methodologies, including training. "Risk management traversed the whole country through "Enhancing Capabilities," argues Leonardo Echeverría, former Risk Management Director in Santa Elena (interview with author August 12, 2018). Thus, from public to private institutions and from national to local levels, RMS reached the most remote localities, generating a culture of risk. The third area of RMS, Response, became relevant when a threat was close to impacting any site, at which point RMS accordingly activated orange or red codes.

The anti-neoliberal risk management in Ecuador adopted the UNISDR methodology to respond to threats and manage disasters. This methodology activates a Comité de Operaciones de Emergencia or Emergency Operation Committee (EOC) to confront a localized threat. EOC is a high-level decision-making group which coordinates 
an emergency, with the primary goal of risk reduction and disaster response by the orderly activating of different levels of Mesas de Trabajo or Technical Working Groups (TWG).

While EOC was the top-level decision-making body during a disaster, "in times of peace" - as Ecuadorian Risk Management officials describe periods of no emergency EOC will focus on coordinating risk reduction and capacity enhancing as part of response preparation. $\mathrm{EOC}^{6}$ operated at provincial and municipal levels by activating different TWG levels: technical, advice, decision-making. TWG detected the need for any mitigation or prevention measure at the local level and informed the upper level of decision-making. In the case of the Provincial EOC, the Governor and Zonal Directors took decisions and followed up mitigation works for lessening adverse impacts. Similarly, a EOC and TWG operated at municipal level decision-making on prevention, in the elaboration of a risk reduction agenda.

Thus, since 2008, risk management practice has expanded exponentially throughout the country. For instance, the report Avances de Gestion de Riesgos 20082013 or Risk Management Advancements 2008-2013 (SNGR 2014), details the following RMS achievements:

- 665 Risk Management (RM) Community Committees created, 321 elaborated their RM Community Plans, practiced 181 drills, and created 67 RM Community Networks. Additionally, 701 Schools practiced evacuation drills.

- $\quad 87$ Climate Forums in the all 24 Ecuadorian provinces.

\footnotetext{
${ }^{6}$ Later on, EOC changed their name to Comités de Gestión de Riesgos or Risk Management Committees. However, the 2014 Risk Management Handbook uses the Spanish acronym COE/CGR in the whole document.
} 
- $\quad$ All 24 provinces' RM units trained with the RM Committee Handbook.

- 3 Provincial Governors meetings to implement Risk Reduction Agendas.

- 19 Risk Reduction Agendas implemented and led by Governors.

The same document shows communication strategies RMS applied to reach the most remote Ecuadorian:

- The Caravana de Gestión de Riesgos por el Buen Vivir or RM Convoy for the Good Living visited 84 cantons to disseminate RM policies through sociocultural activities and distribution of brochures to alert the population of threats.

- Throughout the project, Reducción de Riesgos en la Comunidad Educativa Frente a Amenazas de Origen Natural or Risk Reduction in the Scholar Community Exposed to Natural Threats, roughly 3000 schools elaborated Risk Reduction Plans. RMS trained roughly 35,000 teachers and 16,000 community members.

- One hundred and fifty-six campaigns provided more than three million people with clear information on preventing risks of a tsunami, forest fires, flooding, mudslides, or seismic activity.

Furthermore, the same report shows the increasing participation of municipalities in risk management strategies. By 2008 , only $2 \%$ of cantons had signed the agreement with RMS to work together on risk reduction. By 2011, agreements increased by $16 \%$, and by $2013,31 \%$ of cantons had RM Units (departments) operating. By 2014, more than $50 \%$ of the municipal ADGs had adopted risk management into their administration. In addition, by 2013 RMS had trained 101 of Ecuador's 221 cantons in organizing the RM department, and 70 had incorporated risk management in their planning. Although risk 
management machinery had reached municipal administration, RM departments aimed to mobilize risk at the community level. The next section addresses risk management in Santa Elena to reveal risk management at rural levels of administration.

\section{Resilience building and risk management in the province of Santa Elena}

Santa Elena is the southwestern and newest province of Ecuador. The province has 112 miles (180 kilometers) of shoreline with particular climatic threats due to the geographical components: a range in the west, estuarine zones in the north, and the Pacific Ocean in the east. The second level of administrative sub-division in Ecuador is cantons (or municipalities). Thus, Santa Elena is also the name of one of the three municipalities comprising the Santa Elena Province. The canton of Santa Elena has an urban parish (third level of government), also called Santa Elena, which occupies $5 \%$ of the cantonal territory. The other $95 \%$ of Santa Elena's municipal territory comprises six rural parishes: Atahualpa, Chanduy, Colonche, Manglaralto, San José de Ancón, and Julio Moreno. Rural parishes comprise 152 rural villages, most of them grouped in 68 communities known as comunas, which are common-property territories ruled by a special regime (Law of Communes) since 1937. Consequently, the province of Santa Elena comprises provincial, municipal (or cantonal), parish and comunal or community levels interweaving local governance. In this section, I trace anti-neoliberal governmentality addressing risk management among the rural communities of Santa Elena.

After enacting Santa Elena into a province in November 2007, the leftist government introduced numerous changes and new actors in local governance. The 
province created a Governor's office, a Prefecture, and a Zonal Government Building. In that building, the national government housed several branches of ministries and secretariats, including Tourism, Public Works, Education, Health, Foreign Affairs (migration services), Telecommunications, Agriculture and Livestock, Energy and Mines, etc., to execute the strategies of national planning in Santa Elena, while locals were appointed to most of the new governmental positions. Similarly, in 2009, RMS opened an office in the Zonal Government Building.

The inaugurated Provincial Coordination of Risk Management, later called RM Direction, aimed to promote and implement RMS strategies in the province of Santa Elena. Under the anti-neoliberal participatory principle introduced into the national planning, RMS in Santa Elena promoted the creation of technical committees to address El Niño phenomena. Concurrently, other sectoral committees functioned in the province. Those committees informed the Provincial EOC, by which the Governor and Zonal Directors took decisions and followed up with mitigation works. Similarly, EOC's participative model operated at the municipal level. An example of the scalar and the informative process of decision-making in Santa Elena is the First Contingency Plan for Flooding issued in 2009.

RMS' provincial office worked together with the municipality of Santa Elena and other stakeholders through the TWG methodology, briefly explained in the previous section. RMS provincial office in Santa Elena also created Risk Management Committees (Resolution No. SGR 367-24), another participative process gathering public and private stakeholders, to analyze municipal issues. Risk Management Committees also operated at the parish and comunas levels. I argue that all participatory encounters 
produced new experiences to the locals, re-conceptualized risk, and located the need for securitization at the center of the comuneros.

The initial goal of the provincial office was to identify risks and vulnerabilities in Santa Elena. RMS achieved it through participatory techniques. RM officials I interviewed admit they had initial data elaborated by foreign and local agencies. However, the anti-neoliberal participatory scope required a bottom-up approach to promote the integrated logic of risk. Thus, the provincial office of RMS created spaces to generate local input on furthering risk management policies. Applying the TWG methodology, Santa Elena's RMS staff worked for roughly three years gathering citizens' concerns and ideas for addressing local risks and vulnerabilities. The TWG connected different levels of participation, from national RMS officials to local government officials, to community levels of organization and vice-versa (Emilio Ochoa, former RMS staff, interview with the author August 31, 2018). Thus, the bottom-line data emerged from the community, including ancestral practices to confront natural disasters. For instance, RMS officials reviewed local calendars that annually announce the comuneros about drought periods, insect and other infestations, harvesting times, ideal times for controlling scrubs and weeds, and so on (E3 interview with author June 16, 2018). Similarly, "the comuneros showed us the cemetery area is the best site to evacuate to during flooding or severe rainfall," comments a former RM official in Santa Elena (E2, interview with author June 16,2018). Thus, active collaboration and participation allowed RMS officials to facilitate a process centered on criteria of risk.

RMS staff also gathered collective memories regarding natural disasters. However, it was not an easy task for RMS officials deployed in Santa Elena. Comuneros 
do not easily remember natural disasters that have affected their communities, argue several RM officials I interviewed.

"The population tends a little to forget what affected them.... they think that [disaster] will never happen again" (E17, RMS official, interview with author August 12, 2018).

"Maybe they have not learned the lesson and will still make the same mistakes" (Richard Flores, RMS Unit Director at the Prefecture of Santa Elena, interview with author July 31, 2018).

"They consider that the only one capable of deciding if something was going to happen or not is God and that they are in the hands of God" (Enrique Ponce, former RMS Provincial Coordinator, interview with author August 30, 2018).

"Comuneros in general, particularly in Libertador Bolivar, forget about past experiences and repeat them"(David Zambrano NGO Director, interview with author August 12, 2018).

Similarly, comuneros I interviewed did not reflect much on disasters' aftermath despite ENSO 1982-1983 and 1997-1998 having significantly impacted the local economy. Instead, they perceived that nature will continue impacting them, and they have to adapt to the change such events bring into their lives. They argue that people are unable to anticipate a natural catastrophe or its intensity. For instance, Smeling Suarez, a comunero leader, asserts:

"We do not raise awareness .... we do not pay much importance to the events" (interview with author June 22, 2018) 
Thus, RMS workshops addressed memory recovery by applying the practicetheory-practice methodology, a participatory methodology for social intervention developed in Costa Rica, which is derived from everyday life, explains Enrique Ponce, former RMS Director (interview with author August 30, 2018). The methodology aimed to raise awareness by appealing to emotions based on past experiences. Ponce recounts that RMS-promoted workshops in Santa Elena connected comuneros' past experiences to past emergencies, by guiding the comuneros to remember the events (floods caused by ENSO, or problems of water deficit). When remembering these events, the comuneros realized that disasters could happen again. "Sometimes they remembered their experiences with much fun, others were unfortunate," comments a former RMS technician in Santa Elena who participated in those workshops (E2 interview with author June 16, 2018). Thus, sadness discloses comuneros' mistake, states another former RMS staff of Santa Elena who also participated in the workshops (E3 interview with author June 16, 2018). For instance, remembering crops lost, mudslides or severe raining damages, made comuneros sensible to El Niño's impacts (E11 interview with author July 10, 2018). By bringing up emotions, regrets, sensitivity, RMS staff successfully connected risk management's preventive criteria to the comuneros' everyday lives. In this way, RMS officials introduced worldwide hegemonic concepts such as risk, threat, vulnerability, and prevention. Once locals identified the risk factors, the RM team asked them for alternatives to reduce such factors. All the information was fed to upper levels of decision-making and came back to the local level in the form of strategies to reduce vulnerability. 
Additional measures - known as non-structured measures - to reduce comuneros' vulnerability accompanied RMS machinery. Among the non-structured measures evacuation routes implementation, community emergency plans, emergency brigades. Initially, RMS officials coordinated and participated in evacuation drills at schools and created brochures, games and educational material to transfer knowledge to students. Currently, the Ministry of Education has an RM policy to address prevention in the entire country's school system. On a monthly basis, the school staff and students practice evacuation procedures in case of a catastrophe of any kind. They are known as simulacros or drills. According to the Principal of a school in rural Santa Elena, "The more drills done, the more of a habit that is created. They create awareness before any event" (E4, Comunera leader, interview with author July 3, 2018) Indeed, according to a former RMS official in Santa Elena (E3 interview with author June 16, 2018), comuneros know what to do, where to go, how to act. Thus, while the comuneros voluntarily accepted RMS' technical intervention, the need to be prepared also emerged as normal (Chapter 2). Following international frameworks on disaster management, RMS in Ecuador conceived that survival relies in large part on people taking care of themselves, and not merely on a quick governmental response to the emergency. In doing so, RMS aimed to strengthen locals' capacity as first responders in the event of a catastrophe, giving locals more opportunity to subsist when prone to a disaster.

\section{A biopolitical approach to social construction in Santa Elena}

In the case of Santa Elena, training enhanced locals' capacity to respond to natural threats. Kevin Grove (2014b) argues that disaster-management training de-territorializes 
local knowledge of hazards, and the case of Santa Elena instantiates this argument. By de-territorializing knowledge of hazards, Grove points out the displacement of local relationship with natural threats and traditional responses to disasters, while new riskrelated ideas are introduced. For instance, RMS in Ecuador introduced the idea of tsunami among the comuneros, particularly after evacuation drills became regular. However, there is no memory of a tsunami in Santa Elena. Elders I interviewed do not remember stories about the Pacific Ocean's waves battering the coast in a manner that destroyed a vast territory. A local story about a community called Olón (translated as Huge Wave) tells that the name came about because a giant wave supposedly battered the community. On the contrary, another story among the comuneros, argues that the name of the comuna Olón originated from the name of the Cacique Olonche. Indeed, there is no official record of a tsunami impacting Santa Elena's coastlines.

The 1993-1996 Development Agenda mentions that tsunamis threaten 10\% of the population settled on the shoreline. The report was issued after ENSO 1997-1998 mentions tsunamis three times as a possible threat. However, it does not document a tsunami having impacted the Ecuadorian coast (CAF 1998). OXFAM's analysis of natural threats by canton includes a section devoted to earthquakes and tsunamis. The report mentions that earthquakes provoke "seaquakes or tsunamis" (OXFAM 2001, 10) and merely reports that two cases occurred in 1906 and 1958. Both events affected the northern coasts of Ecuador, in the province of Esmeraldas and the southern coast of Colombia. Willington Renteria, an expert at the Oceanographic Institute of Ecuador, states " there is scarce data of a local tsunami that has hit the [Ecuadorian] coasts" (Renteria 2007, 212). However, Reintería noted there were reports that on December 12, 
1953, an earthquake occurred near the border of Ecuador and Peru that caused a tsunami in Japan and increased sea level in Santa Elena by $0.20 \mathrm{~m}$.

I do not deny the possibility of a tsunami hitting the coast of Santa Elena, yet, my argument is that the possibility of a tsunami moved the daily coastal life into "a new set of worries" (Giddens 1999, 3). Specialized analyses of tsunami threats in Ecuador are not new. Since 1976, Ecuador joined the Tsunami Warning System as part of the global network of tide gauges. In addition, the country appointed the Ecuadorian oceanographic office to the Pacific Tsunami Warning Center located in Hawaii (SNGR 2012). During the last decades of the 1900s, the Oceanographic Institute also evaluated and modeled tsunamis. Finally, in 2007, the Ecuadorian Oceanographic Institute created the Centro Nacional de Alerta de Tsunamis or Tsunami Warning National Center, which monitors 24/7 seismic occurrence in the Pacific Ocean, and keeps the government informed about tsunami events in the world (SNGR 2012).

Later on, the Ecuadorian government installed buoys and tide gauges to obtain real-time information, and devices to determine water column deformation from the open sea (SNGR 2012). However, as I argue, knowledge about tsunamis must be transferred to the community:

"Another objective of the National Center for Tsunami Warning is to transfer information about tsunamis to the community, through written media and other means. Therefore, INOCAR [Ecuadorian Oceanographic Office] plans activities aimed at improving knowledge about tsunamis in mainland and island coastal populations" (SNGR 2012, 73), emphasis added. 
RMS achieved the transfer of information about tsunamis and other kinds of natural disasters to rural seaside villagers by promoting numerous communitarian prevention programs. The goal was making people aware, so they are able to protect themselves. In doing so, RM built resilient communities (El Universo 2017, emphasis added).

Thus, while the subsidiary principle allowed risk to become transversal to all levels of governance, the capacity-building component, achieved locating risk at the center of the comuneros. According to this culture of risk, if nature is a permanent threat, then locals must be alerted and prepared to respond appropriately. However, several RMS staff members emphasize the peculiarity of each community to respond to disasters. In the case of Santa Elena, "the comuneros put forward their collective support, there are no barriers that inhibit their solidarity," states Richard Flores, Municipal RM Director (interview with author July 31, 2018). Paradoxically, "Comuneros self-organization is not the product of RM programs." RM programs are designed to work in "urban settlements rather than rural conditions," argued the interviewee. In addition to the organizational capacity-building, structural measures were also part of the risk management machinery in Ecuador. In the next section I address anti-neoliberal governmentality to protect beaches at Santa Elena.

\section{Armoring beaches: the structural measure to protect Santa Elena}

Relentlessly, waves and tides act upon the shoreline moving sand or carving headlands, like cliffs. Such dynamic forces remove coastal land while water supplants the land, eroding or shrinking the shoreline. In addition, other stressors, such as sea level rise and ENSO, also threaten shorelines. Nowadays it is usual to see all kind of physical 
construction between the sea and the land aiming to control the sea and to mitigate its threats. Quite often, we can be walking through a beautified promenade without noticing it is built on the top of a seawall. Seawalls are vertical shore-parallel walls to prevent the beach and coastal infrastructure from the detrimental influence of huge ocean waves and flooding (Sadeghi et al. 2018). This type of coastal protection particularly aims to reduce erosion and resist waves' energy. Revetments, or ripraps are other types of structures to protect sandy beaches from erosion or shorelines. Overall, "seawalls, revetments, and bulkheads reduce the impact of wave energy and associated erosion on coastal assets directly behind them along vulnerable shorelines" (Beavers et al. 2016, 101). Artificial barriers are also built in the sea to dissipate the energy of waves, such as offshore breakwaters built parallel to the shore. Furthermore, Duggan and Hubbard $(2010,187)$ argue that the construction of physical structures to protect beachfront "is expected to escalate in response to the combination of expanding human populations, coastal erosion, and sea level rise." In the province of Santa Elena, the construction of coastal protection increased during the anti-neoliberal state practices.

However, the construction of coastal protection started in the years of governments practicing neoliberal formulas. The first one was built in La Libertad, one of the three cantons of Santa Elena Province. In 2003, La Libertad inaugurated five offshore breakwaters, and a seawall with a pedestrian promenade on top. Later on, local government built a rock revetment on Montañita beach, a surfing hotspot comuna in the north of Santa Elena canton. Similarly, the largest cement production company in Ecuador built a protection wall in Comuna La Entrada. In 2006, the Coastal Resource Management Program financed protection walls in other coastal provinces (Cojimíes and 
Bahía de Caráquez, Manabí, and Jambelí, and El Oro). However, the effects of tidal waves and other factors continued in the Ecuadorian littoral.

According to Enrique Sanchez, coastal engineer and seawall designer, $10 \%$ of the Santa Elena Province's shoreline is currently eroded, while erosive effects are threatening an additional $10 \%$ of the shoreline. Furthermore, sea level rise will erode low coasts, barrier coasts, and small mangrove areas and existing deltas in a couple of decades, argues Sanchez (2016). Additionally, low-flow rivers move down to the Pacific Ocean forming tidal ponds that intersperse with the river mouth and sandy beaches. Drastically, during the rainy season (December to May) rivers are prone to extensive flooding. The river becomes a threat to the inhabitants settled next to the estero, as locals used to call the low-flow river. For instance, in 2010, flooding impacted 14,410 Santa Elenians. Between 2009 and 2011, waves battered some beaches in Santa Elena damaging infrastructure and putting the local tourism-led economy at risk.

The Ecuadorian Constitution, Article 73, stipulates the state's duty to apply measures to prevent the destruction of ecosystems or permanent alteration of natural cycles. Additionally, the Constitution indicates that Ecuadorians have the right to benefit from the environment and natural wealth (Article 74), the responsibility to respect the rights of nature, and use natural resources rationally and sustainably (Article 83). In this context, RMS is responsible for designing adequate risk reduction strategies but caring for nature as well. On the coast, RMS must protect beach and river mouth ecosystems while safeguarding the population. Among other norms, RMS issued Resolution No. 0052011 (OR \#460, 2011) banning destruction or exploitation of the natural defenses of the beach, the occupation of berms and beaches' active zone with fixed structures, such as 
cabins, eateries and any other type of structures. The resolution also exempts RMS from compliance with this obligation, as RMS must endorse and approve the execution of any infrastructure to safeguard the population.

In compliance with the 2011 RMS resolution, the Secretariat launched the Prevention and Mitigation Program to Reduce Different Threats Risk. The program planned to invest US\$96.5 million in national risk prevention for seven years (20112017). It was RMS' exclusive decision to endorse and approve construction in each province. In the case of coastal areas, the program determined the construction of flooding prevention infrastructure. The program also specifies hard and soft engineering interventions to protect the beach in coastal areas; examples of hard engineering are walls to canalize rivers and walls to reduce the erosion of beaches. Soft engineering includes planting suitable vegetation to avoid sliding slopes (such as guadúa cane or vetibet).

Both the technical and the financial programs provided local governments tools to build mitigation infrastructure. Thus, the Prevention and Mitigation Program, along with the BEDE funding program, were part of RMS machinery extending down to local management. In Santa Elena, the provincial, the municipal and the parish development plans included the construction of walls to protect the population. Overall, those plans highlight the need for protecting the population from natural threats, particularly flooding, high tides, and ENSO. In 2011, the Santa Elena municipality joined the agreement between RMS and BEDE, as the RM machinery was ready to protect Santa Elena's socio-ecological system by applying hard engineered solutions.

During my fieldwork, I recorded six sites in the province of Santa Elena where national, provincial or municipal governments had built seawalls and river protections. 
For instance, in the Comuna Chanduy, located in a southern parish of Santa Elena canton, a 427 meter ( 0.26 miles) long seawall currently protects the seafront (Figure 6 ). The primary goal of this coastal defense is to repair cliff sinking and prevent coastal erosion. Sanchez (interview date June 18,2018 ) states that cliffs at the beach have retreated 0.5 meters ( 2 feet) per year since 1983 and have $1 \mathrm{~km}$ (0.6 miles) of eroded coast. However, the government did not protect the southern area and locals are currently demanding that the seawall be extended to this area. In Comuna Las Nuñez, the municipality of Santa Elena built a seawall in 2015. This construction required moving two houses (family relocation), and several other houses lost roughly 2 meters ( 6.5 feet) of beach front.

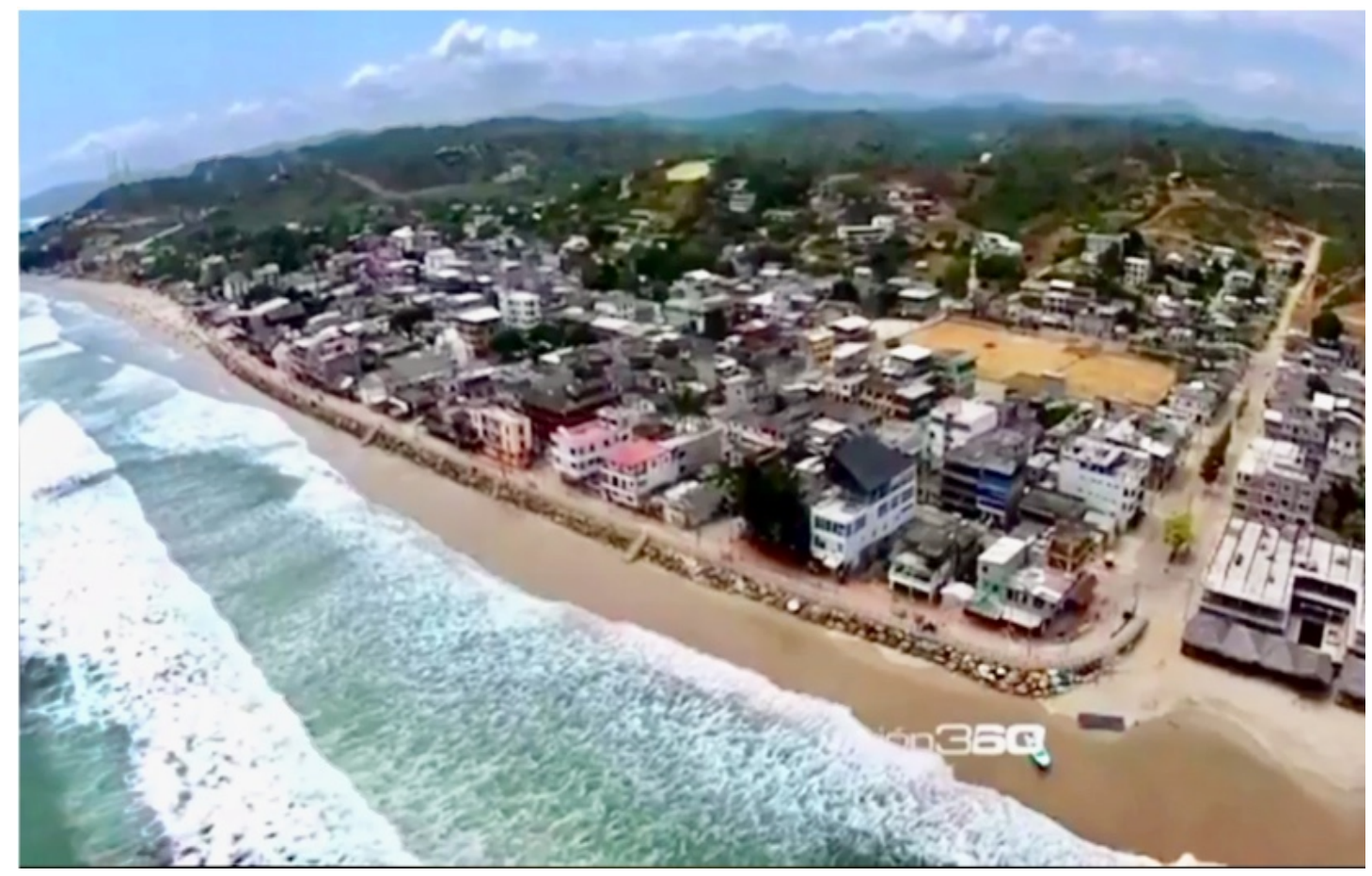

Figure 6. Seawall at Chanduy. Source: Vision360 (2018) 
Similarly, in La Entrada, the northern comuna in Manglaralto, the government reinforced the seawall built fifteen years before. Initially, this seawall was part of the social responsibility program of a private company (Figure 7). Southern, a 493 meter (0.31 miles) long seawall protect the north beach at Libertador Bolívar. At the top of the seawall a promenade provides tourist recreational areas. An extension of 287 meters ( 0.17 miles) to the southern beach was still under construction as of September 2019. In the comunas of Montañita (Figure 8) and Manglaralto (Figure 9), the municipality reinforced protection walls previously built.

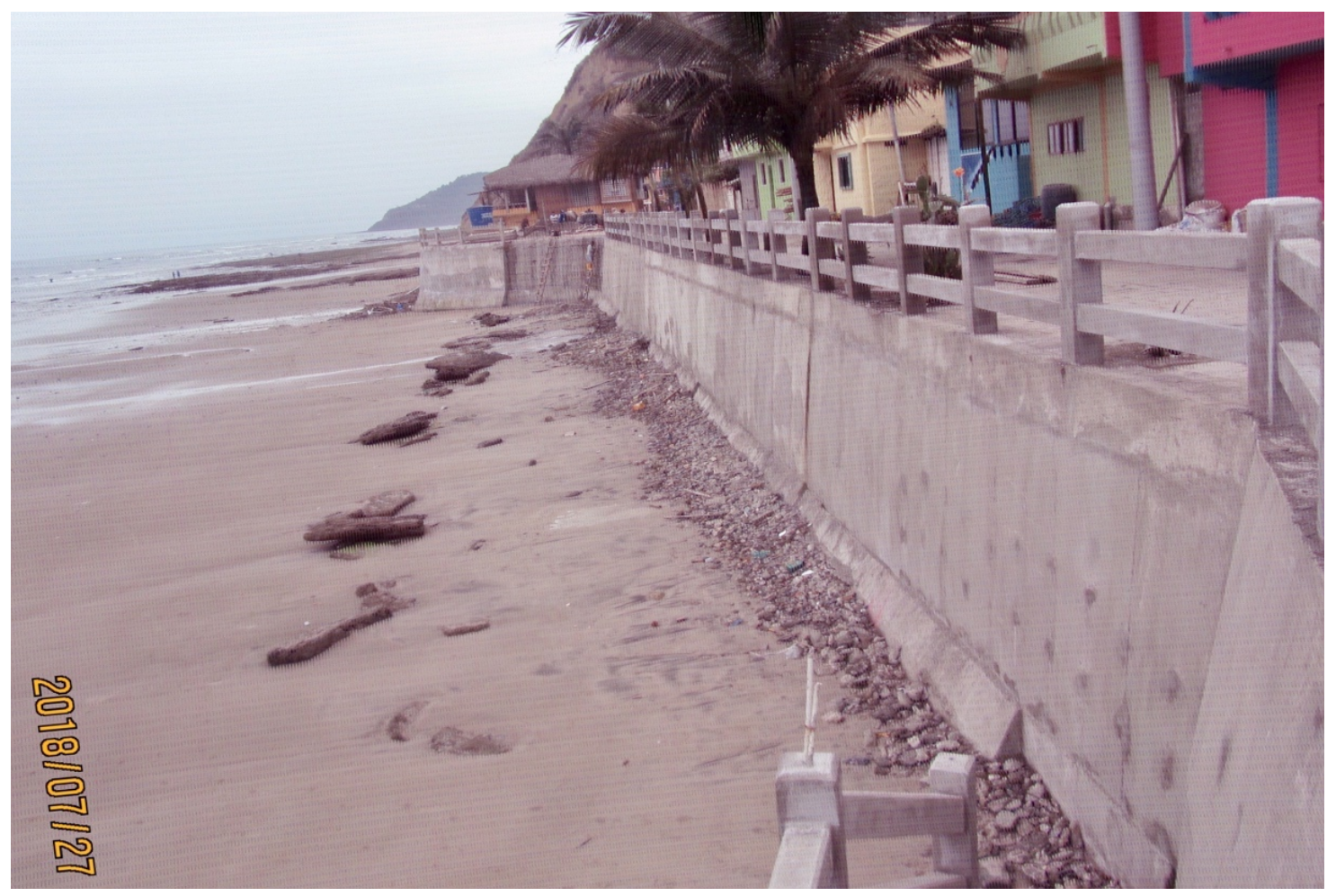

Figure 7. Coastal protection at Comuna La Entrada. Source: Author (2018) 


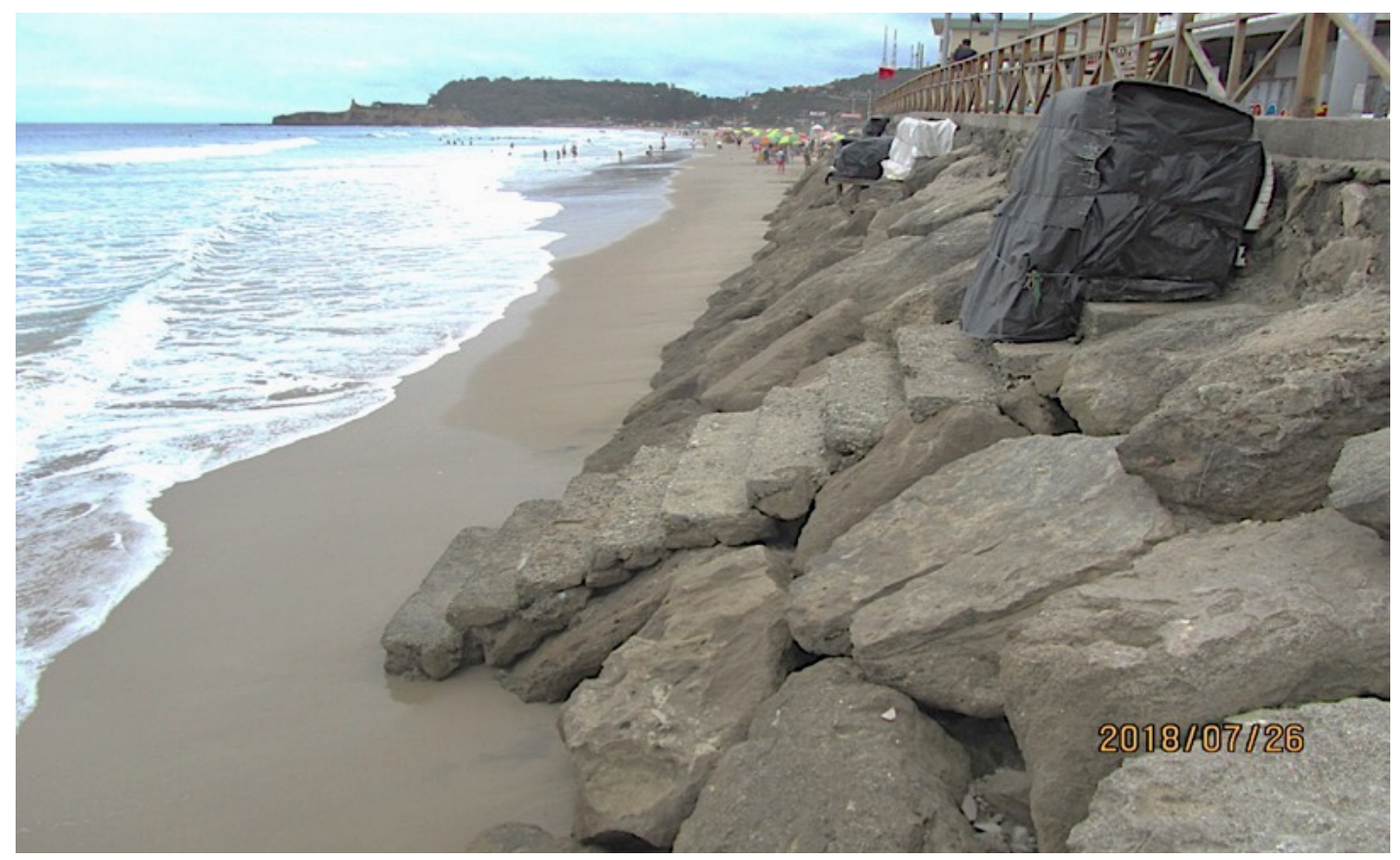

Figure 8. Seawall at Comuna Montañita. Source: Author (2018)

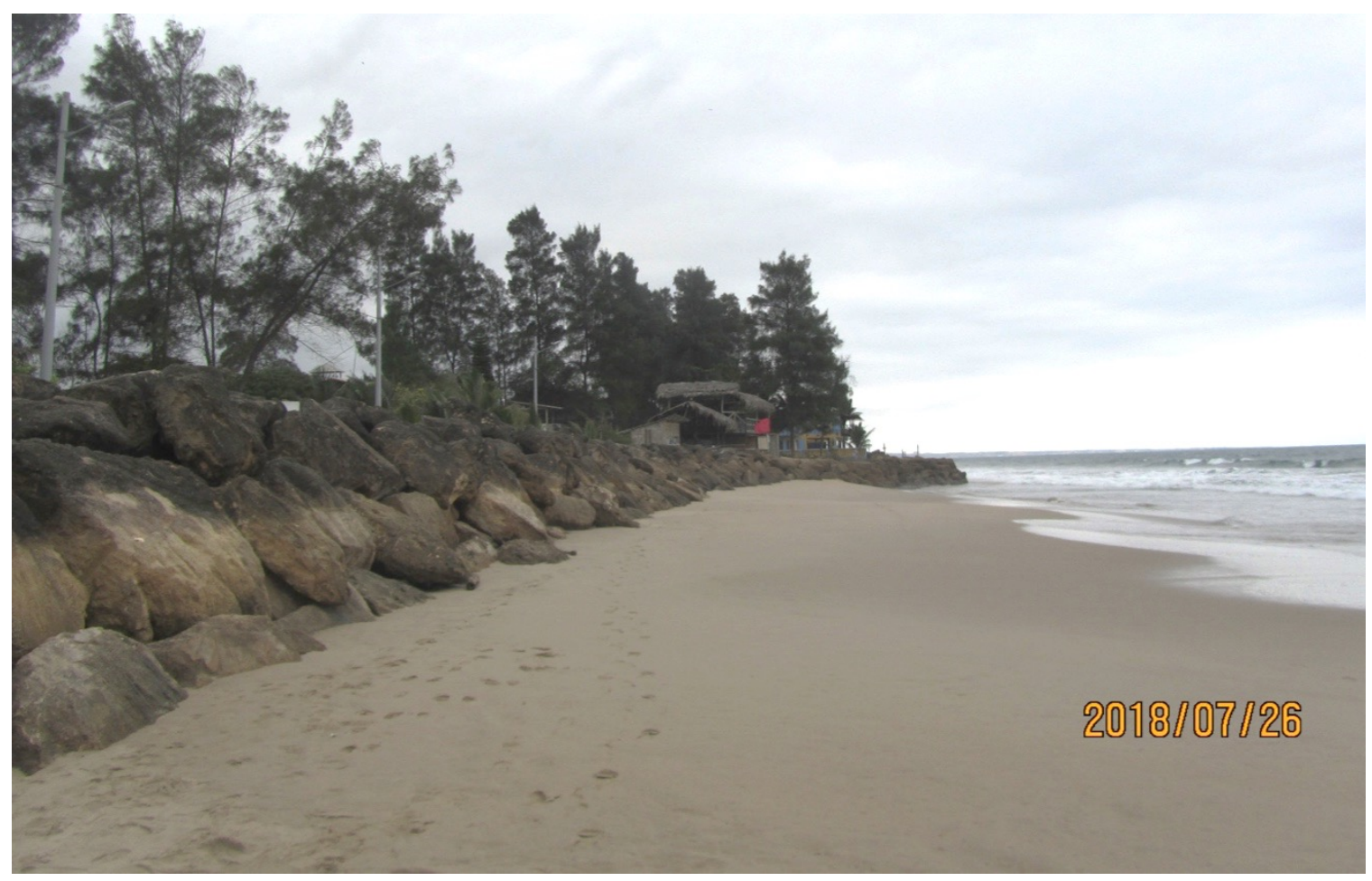

Figure 9. Seawall at Comuna Manglaralto. Source: author (2018) 
The Prefecture of Santa Elena which, according to the General Code of Territorial Organization, Autonomy, and Decentralization, is responsible for river basins and microbasins, has also built mitigation works to prevent flooding in Santa Elena's cantons. For instance, the slow-flow rivers in Montañita, Manglaralto, and Libertador Bolívar (Figure 10) are currently armored with retaining walls. Similarly, the Ministry of Transportation and Public Works built protection walls (translated in Spanish as Muro de Escolleras) in some areas of route E-15, which connects the coast of Ecuador from north to south. Notably, in Santa Elena canton, between the comunas of San Pablo and Pacoa, $1 \mathrm{~km}$ of seawall currently protects route E-15, which runs next to the Pacific Ocean.

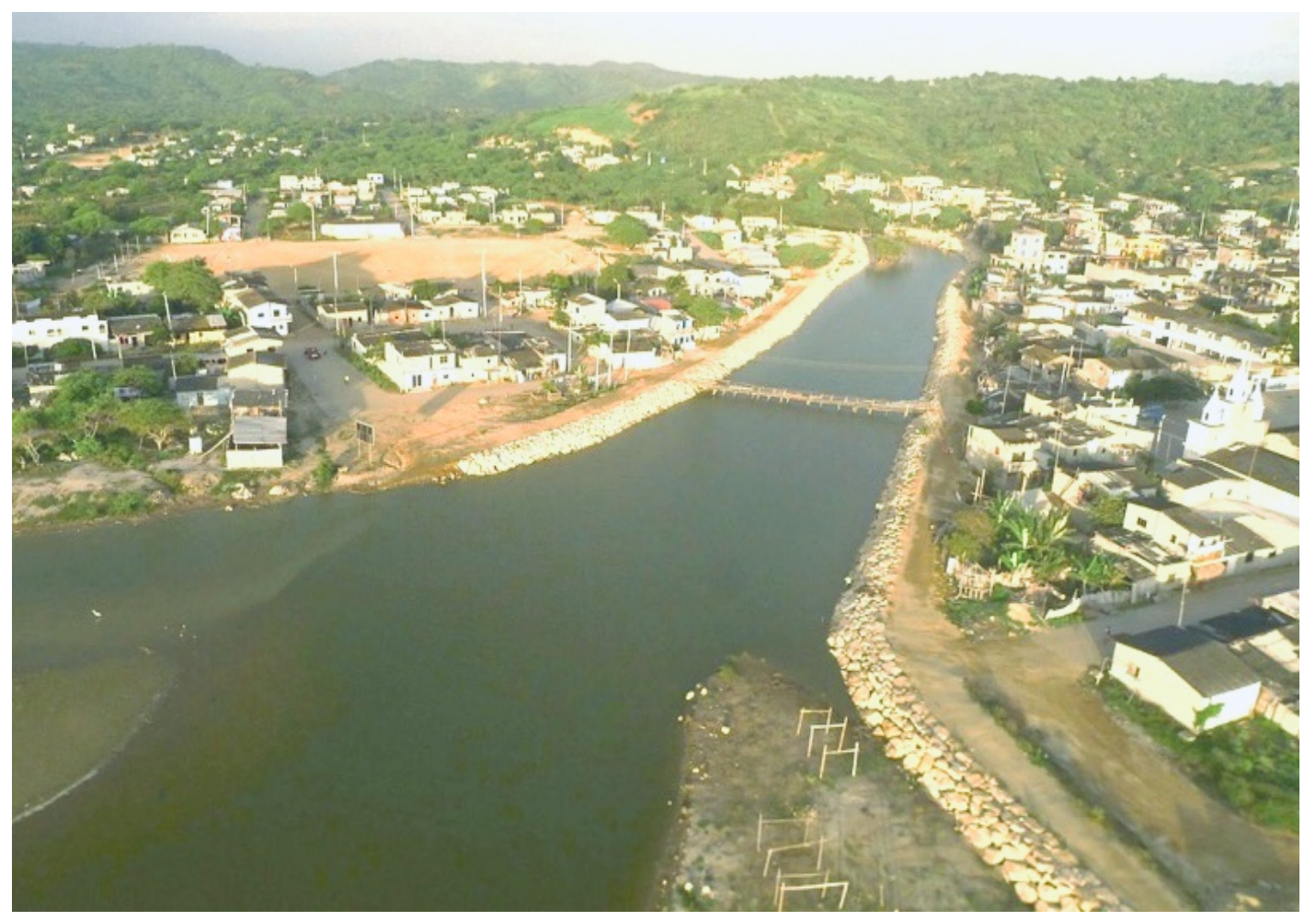

Figure 10. River mouth of Atravezado River protection at Comuna Libertador Bolívar. Source: Coastman Foundation (2018) 
Among its benefits, hard engineering stabilizes the upland and protects

infrastructure. Conversely, shoreline armoring increases erosion on the beach adjacent to the wall and increases the loss of dry beach, thus decreasing the recreational use of the beach (Shipman et al. 2010). More concerning are the effects of man-made protection walls on marine habitats. Some academic works show changes in ecological function of marine organisms (Chapman and Underwood 2011). Moreover, some coastal states in the US have restricted and banned physical constructions along their shoreline (O'Connell 2010). No reports on detriments have been as yet documented on Santa Elena's armored beaches. The comuneros continue using the beach as their way to improve their economies. The communes of San Pablo, Olón, Ayangue, Palmar, Bolívar, San Antonio, San Pedro have built cabanas on the beach to offer a variety of tourist services. The requirement to fill basic needs, their desire for progress, is greater than the threats of the sea. The Comuneros promote their small tourist entrepreneurship, while RMS power diminishes through several changes in the national administration.

\section{The weakening of Ecuadorian risk management machinery}

Risk management decentralization and de-concentration processes eventually weakened the RMS machinery introduced under anti-neoliberal practices in Ecuador. As a consequence of CTOAD's decentralization and de-concentration mandate (see above table 4.1), the national secretariat went through a restructuring, while municipal governments assumed RM planning and functioning, argues a former RMS staff (E18 interview with author June 13, 2018). Indeed, since 2014, the RMS no longer builds infrastructure as this is the role of the local government. 
Furthermore, the social construction area merged with other government departments. For instance, in 2014 the Ministry of Education created a National Direction of Risk Management, incorporating risk criteria and social construction into all levels of the national school system. Each school has an RM leader, and once per month students and staff practice evacuation drills (for earthquakes, flood, tsunami, etc.). In Santa Elena, the Ministry of Education practices drills and distributes educational material in collaboration with RMS officials.

By 2018, Santa Elena's RMS office had only two areas: monitoring and response, while staff also collaborate with other governmental offices. Thus, the situation room works monitoring threats 24/7 year-round. In case of an emergency in the Province of Santa Elena, RM activates an EOC, by which the Technical Working Groups gradually actuate according to the level of damage caused by the event. Both EOC and TWG are interdisciplinary working groups with decision-making power to confront an emergency in accordance with the Risk Management Manual, issued in 2014. Additionally, the RMS office in Santa Elena joins the Ministry of Education to provide training (particularly drills) and education (capacity enhancing) using educational material.

Since 2014, the RMS-BEDE project does not subsidize infrastructure construction. According to the RMS-BEDE agreement signed in 2011, BEDE subsidized $50 \%$ of any risk reduction project (sometimes more than $50 \%$ ), while RMS assumed the other 50\%. However, since 2015, BEDE applies a credit line to municipalities that request funds for mitigation work. Thus, currently, local governments have to prudently manage their annual budget for building risk infrastructure. Municipalities are responsible for managing their own risks, for developing and executing risk reduction 
programs, developing response strategies to strengthen cities, and even designing recovery strategies in the event of a disaster.

At the provincial level, the Prefecture of Santa Elena has a different agenda from the municipality of Santa Elena because the CTOAD stipulates two different areas of action for each local government. On the one hand, the municipality controls and regulates beaches, riverbanks, lakes, and lagoons, and manages prevention services. On the other hand, the prefecture is responsible for river basins and micro-basins. In previous years, the prefecture was devoted to building river retaining walls in several comunas of Santa Elena, for instance, in Libertador Bolívar (Figure 10) and Manglaralto (Figure 11). Nowadays, the Prefecture's RM department is creating elaborate provincial programs to address Climate Change adaptation and to prevent forest fires (Juan Antón, current RM Director, interview with author, June 13, 2018).

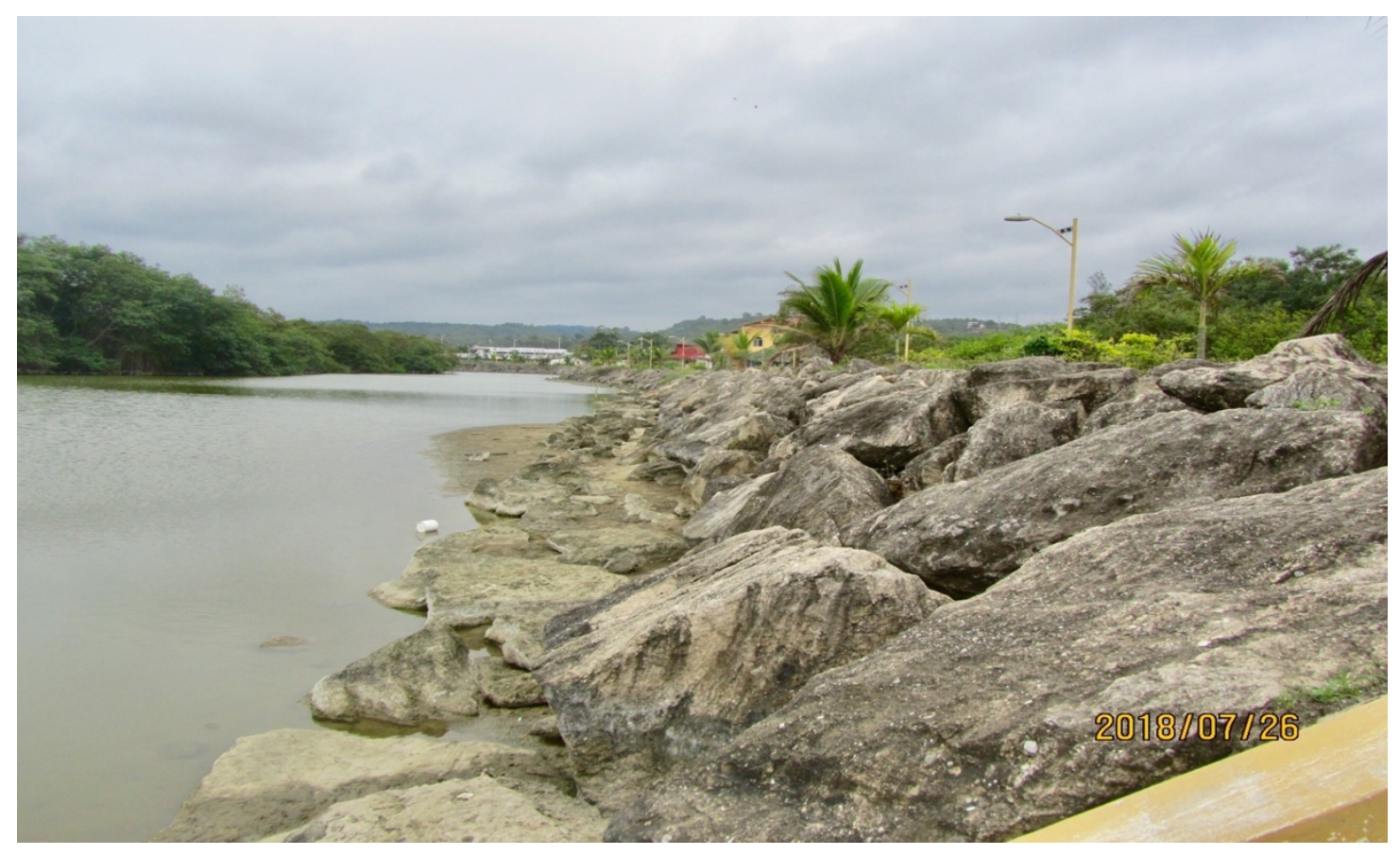

Figure 11. Manglaralto river wall. Source: The author (2018) 
At the national level, the April 16, 2016 earthquake (7.8 Richter scale) revealed the weakness of the RMS. The government failed in rapidly responding to the disaster and post-disaster recovery. (See Carrion et al. 2017). One year later, a new government took presidential office, introducing profound actions that reduced RMS' power. On October 3, 2018, President Lenin Moreno signed the Decree No. 534-2018, derogating Executive Decree No. 42-2009, by which the Technical Secretariat of Risk Management became a National Secretariat of Risk Management in 2009. The decree 534-2018 changed the name of RMS to National Service of Risk Management and Emergencies. Said decree also created the National Service of Risk Management and Emergencies Committee, an interdisciplinary committee responsible for regulating, planning and coordinating the National Decentralized Risk Management System. The committee integrates the President of Ecuador, the National Planning and Development Secretary, Housing and Urban Development Ministry, National Defense Ministry, Finance Ministry and the Director of the National Risk Management and Emergencies, who can participate but cannot vote in the committee.

Thus, the former ubiquitous and powerful secretariat returned to being an office dependent on an inter-institutional committee, which will lead and coordinate risk management and emergencies. Alexandra Ocles, RMS Secretary at the time the president issued the decree reorganizing RMS, explained that those changes mean "that actions RMS has been taking must go up to the committee to be executed," (Radio Publica, October 11, 2018). Furthermore, the current Ministry of Defense, a retired General, 
submitted to the National Assembly, a proposal drawing together defense, strategic intelligence, security and risk prevention, as it was during the neoliberal regime.

According to the former Risk Management Secretary, Pilar Cornejo, Moreno's decision "sets back risk management in Ecuador" (personal e-mail). She argues that risk management in Ecuador comprises not only the last ten years of anti-neoliberal state practices, but also risk criteria started as far back as the early 1990s. Currently, the constitutional mandate is at risk, Cornejo states, because the Ministry of Defense follows a rigid command chain, top-bottom decision-making that ignores the bottom-up approach implemented by RMS.

Significant here is the political instability that characterizes Ecuador. A decade of anti-neoliberalism filled RMS with autonomy and power. RMS could circumvent the weakness coming from the decentralization and de-concentration by enacting new laws. However, the new government moved RMS back, eventually minimizing RMS' autonomy and power. The new Servicio Nacional de Gestión de Riesgos y Emergencias or National Service of Risk Management and Emergencies will retain measures to train people as first responders. President Moreno justified RMS reorganization as part of the state's budget policy. At the local level, RM responsibility stays within the municipal structure.

However, as several current RM municipal officials argue, politicians are not truthfully concerned about prevention. The political decision is a significant issue when technically managing risk. Populist politicians are in search of voters during elections, and they take advantage of emergencies, argue some RM staff. Thus, emergencies locate politicians as key actors in meeting public needs. Then, the emergency gives the 
politician a good chance of being re-elected. Moreover, politicians do not understand the culture of risk promoted in the era of an anti-neoliberal rationale ruling the country, instead they focus on political benefits, viewing risk as merely technical. However, in actuality, risk is highly political. The risk is in the center of everyday lives since hazards have become a condition of the possibility of development (Reid 2018). In Santa Elena, risk management criteria led decisionmakers to armor the beaches to protect the population and the tourism infrastructure, crucial for seaside comunas' development.

\section{Conclusion: making resilient comuneros?}

In this chapter, I analyzed the neoliberal and the anti-neoliberal rationale for managing disasters in Ecuador in general, and the coastal province of Santa Elena, in particular. From 1980 to 2006, Ecuadorian governments espousing neoliberal practices engaged global trends on disaster management. The risk variable became part of sustainable development, a pivotal discourse organizing Ecuador's modernization during the 1990s. However, the triad development-environment-risk failed to confront natural disasters impacting the country during the same decade. In the coast of Ecuador, ENSO 1997-1998 revealed legal mismatches mixed up prompt and appropriate responses to disaster relief. In addressing such concerns, the Ecuadorian governments paved the way for embracing international frameworks on disaster and risk management.

As Pilar Cornejo, former RMS Secretary, states, the risk criteria started in the 1990s, but the anti-neoliberal government embraced such concepts with the goal of improving the population's wellbeing. To address disaster management failures, the antineoliberal legal framework combined planning, development and risk management. Planning replaced the environment in the neoliberal triad, particularly because nature 
became the primary threat to the population, after the catastrophes of the 1990s. Viewing nature as a threat, then, the government adopted UNDRR frameworks to prevent and respond to natural disasters. Consequently, to construct more resilient and less vulnerable communities, RMS 1) imprinted a logic of prevention that locates nature as a threat, a culture of risk, and 2) intervened by building hard engineering. Indeed, RMS spread a culture of risk throughout comuneros, along with armored beaches to protect socioecosystems.

A biopolitical approach to disaster and risk management in Ecuador unpacks the creation and introduction of a system of knowledge of risk and the techniques the antineoliberal resilience building applied in the coastal comunas of Santa Elena. The antineoliberal State practices achieved a total re-conceptualization of disaster and risk management by de-centralizing it into local governance. Consequently, armored beaches now mitigate seaside villagers' exposure to unpredictable hazards, while the comuneros have adopted this new discourse that centers potential risks in their everyday lives. RMS mobilized mechanisms of active participation and collaboration while the comuneros voluntarily accepted and adopted the culture of risk. In doing so, RMS aimed to strengthen locals' capacities for first responses in the case of a catastrophe. Then, locals had more opportunity to subsist when prone to a disaster. Comuneros are now aware of their vulnerability to floods, and rising sea levels, ENSO-related events, and tsunamis, but they are also trained to respond to a disaster. Ultimately, the risk machinery positioned a new set of worries, a new normality, strongly influencing their present affairs. 
Thus, in Santa Elena, RMS spatialized disaster through social and non-social strategies and techniques deployed in rural coastal areas. However, such bureaucratic, decentralized and participatory methods were not new to the comuneros of Santa Elena. Prior to RMS, a long-lasting development program based on resilience in ecology criteria pervaded comuneros' everyday lives. The next chapter analyzes the creation, functioning, and effects of this development program, which promoted the sustainable use of Santa Elena's beaches. 


\section{CHAPTER V}

\section{A different genealogy of resilience in Ecuador through integrated coastal resource management}

Since the 70s, sustainability had emerged as a critique of production-oriented resource management. The critique of this traditional resource management revealed entrusted distant technicians, who were ignorant of local conditions and overlooked human-environment complexity (Ostrom et al. 2007, Berkes et al. 2003). Furthermore, such conventional view assumed predictability and control of nature. However, command and control's myopia led to management policies that weakened resource sustainability (Grove 2018a). Resilience in ecology converged with the critique of conventional management of resources, introducing uncertainty, adaptation, and pluralism in resource management (Berkes, 2010). Thus, resilience ecologists incorporated the role of social institutions, organizations, networks, and agency into environmental management (Folke 2016). Under this light, resilience scholars advocated for and promoted adaptive forms to manage resources. Adaptive management pursues ecosystem feedback through collaborative process between experts and local managers through the experience simulations at local level that will inform alternatives to improve resource management.

Resilience ecologists broadened the scope of adaptive management by including governance of natural resources. According to Folke (2006), ecosystem management should incorporate ecological dynamics which entail a continuous learning from local knowledge and the importance of ecosystem feedbacks. In doing so, instead of command 
and control resource management, governments should build adaptive capacity to deal with internal or external stressors in a multi-level governance, argues Folke. Similarly, Berkes et al (2003) argue that ecosystems governance should strength local selfgovernance while connect local ecological feedback to higher scale governance institutions. Consequently, adaptive governance advocates for governments transferring decision-making and power to a local scale within a circumscribed local authority (Olsson et al 2004). However, adaptive governance does not supplant adaptive management techniques. Rather, "if adaptive management placed new demands on the process of managing and generating knowledge about complex ecosystems, adaptive governance places new demands on the governance system that forms the institutional context in which management and knowledge generation occurs" (Grove 2018a, 123). In addition to monitoring back loops and enhancing self-organization, several case studies also revealed the need for participatory processes in adaptive forms of governance (Dietz et al. 2003). Thus, adaptive governance allocates responsibility and authority among national and local levels of governance while fosters stakeholders' active participation.

Elinor Ostrom, a Nobel prize economist who became an influential resilience scholar, provided foundational analysis to the critique of global formulas distant from local realities that manage natural resources (Ostrom et al. 2007, Ostrom and Janssen 2004, Ostrom 2008, Grove 2018a). After acknowledging human-environment complexity introduced by resilience ecologists, resource management should diagnose and monitor the multiple processes occurring in nested SES, claims Ostrom (Ostrom et al. 2007, Ostrom 2008). In this sense, the back loops of the adaptive cycle should inform environmental managers to design policies according to local realities. According to 
Grove (2018a), who traces the development of adaptive management and adaptive governance, among Ostrom's major contributions were eight principles to design successful management of resources. Through these principles, Ostrom aimed to counter resource management panaceas to which locals should adapt, since those resource management mainly responded to market-based solutions or state-led plans (Grove 2018a). Additionally, argues Grove, those principles for institutional design allows to identify governance levels and policy interventions toward improving environmental management outcomes.

This chapter traces a methodology that adopted Ostrom's principles to manage coastal resources: Integrated Coastal Management (ICM). In the early 70s, the Coastal Resource Center of the University of Rhode Island (CRC-URI) developed and implemented ICM methodology in the US, to address coastal resources management deterioration as a consequence of federal and state governance mismatches. Ecuador adopted an Integrated Coastal Management in the mid 80s pursuing Ecuadorian coastal areas conservation after the changes the shrimp-industry introduced in estuaries and the extensive mangrove deterioration. I argue that ICM offers connected but distinct genealogy of resilience, one that predates disaster management and development institutions in Ecuador. To understand ICM worldwide development and influence, I trace the emergence of ICM in the first section of this chapter. The second section details the ICM methodology. Later, in the third section, I move down the analysis to Ecuador. I trace twenty years of ICM in Ecuador, nationally promoted by the Coastal Resources Management Program (CRMP). The section particularly provides a genealogy of ICM in the now province of Santa Elena until CRMP merged to the Ministry of Environment in 
the year 2008, a time when the anti-neoliberal government restricted relationships with influential organizations such as IMF, WB, IDB, USAID. The fourth section focuses on the effects of ICM and CRMP in Ecuador. Finally, I conclude the chapter comparing ICM in Ecuador and adaptive governance methodology introduced by resilience ecologists. In doing so, I contextualize resilience morphing alongside other ways of governing life, distinct from the traditional disaster management scope.

\section{International concern on coastal management}

Ecological deterioration of coastal areas introduced actions towards adequate management of coastal resources in the 60 s. In the US, ecological concerns on coastal zones - where the marine and terrestrial environments interface - rocketed after President Kennedy requested to the US Congress to expand efforts in ocean sciences. In the year 1966, through the Marine Resources and Engineering Development Act, the US Congress created the Commission on Marine Sciences. Chaired by Julius A. Stratton, the commission issued the report "Our Nation and the Sea," in 1969. The report details the then-current conditions of coastal areas in the US and the policies on coastal management ruling the country.

The 1969 report addresses coastal zone including seaward and landward (particularly of the tidal zone), the Great Lakes, port and harbor facilities, marine recreational, industrial, and commercial areas. Despite, US coastal states autonomously ruled coastal management, regulations to control coastal zone activities overlapped between the Federal, the State, and the local agencies, the report revealed. In addition to 
conflicts and lack of coordination, the report also revealed the lack of law enforcement in coastal areas.

Thus, the Stratton Commission suggested to keeping vested in the states the primary responsibility of the management of the coast, with federal legislation and agency assisting coastal management. In addition to regulatory framework, the Stratton commission also purposed the creation of a national agency and a national policy. Thus, the National Oceanic Atmospheric Agency was created in 1970, encompassing former agencies that were applying systematic scientific studies on marine areas and weather forecasting. This agency had to assist in environmental monitoring, safety, and enforcement functions, stated the report. Additionally, the Stratton Commission strongly recommended providing policy objectives through the Coastal Zone Management Act. The regulation passed in 1972, establishing "a framework for a federal and state coastal management partnership to balance economic growth with coastal protection" (Tang et al. 2010,106). This act became a strong policy towards coastal management in the US.

The 1969 report also recommended to increase funds for marine sciences and to promote an International decade of Ocean Exploration. The UN welcomed this idea. It was precisely a time when environmental problems started to be a concern in development goals. Indeed, the 1972 UN Conference on the Human Environment had admitted a crucial reconciliation "between the needs of development and the need to protect and improve the environment" (UN 1972, principle 14). The UN had beforehand started to coordinate scientific problems related to oceans and marine biology, establishing an Intergovernmental Oceanographic Commission in 1960 (UNESCO 2006). This commission adopted the 1971-1980 initiative of ocean exploration to expand ocean 
sciences, including environmental forecasting and research on the phenomenon known as El Niño.

By the mid-1980s, environmental problems became an important global issue. The report of the UN World Commission on the Environment and Development (UNWCED, 1987) emphasized ecosystems sustainability to warrant future global economy. This report paved the way to reformulate bureaucratic policies on environmental resources management so far implemented at international level. Particularly in the coastal zone, scientific knowledge had revealed a disconnection between management and development (Adams 2009). In 1992, the Rio Declaration on Environment and Development integrated environmental needs to the process of development.

The cornerstone Rio Declaration and Agenda 21 urged the countries to "increase preparedness to deal with the potentially far-reaching impact of climate change upon the coastal zone" (Post \& Lundin 1996, 2). The Agenda 21 Chapter 17, which, addresses to oceans and coastal areas, called for an "integrated approach to protection and development of marine and coastal resource" (Birch \& Reyes 2018, 8). The purpose of integration was to optimize the relationships between coastal uses in conjunction with the protection of coastal ecosystems (Heemskerk, 2001). Ten years later, the 2002 World Summit on Sustainable Development discussions also addressed to ensuring the sustainable development of the oceans and coastal areas.

The UN 2002 report Section IV item 30 explicitly states nation-states must promote the program of action provided by the Agenda 21. Particularly, Item 30(e) stipulates: 
"Promote integrated, multidisciplinary and multisectoral coastal and ocean management at the national level and encourage and assist coastal States in developing ocean policies and mechanisms on integrated coastal management" (UN 2002, 23).

Overall, the UN declaration connects the integrated management and the sustainable development of coastal areas under an ecological approach. The goal was then to address fundamental development issues, such as poverty alleviation and equity in coastal areas. However, ecologists warned on the effects of the rapid socio-economic development, particularly in developing countries (Haq et al. 1997). Paradoxically, the ecological scope "urg[ed] the need for conservation and protection of the natural resources and environment" while economists "had traditionally advocated resource exploitation to support growth and development" in "near ecological vacuum" (Haq et al. 1997, 1). In a similar vein, ICM criteria acknowledge the awareness of human activity particularly over the coastal environment system and the continuous process in which decisions are made for the sustainable use, development and protection of coastal and marine areas, and coastal resources (Avellar et al. 2014). In the next section, I detail the methodology ICM introduced in worldwide coastal resource governance.

\section{Integrated coastal management methodology}

Stephen Olsen, founding CRC-URI director, pioneered ICM in the US and several tropical countries. In 1971, the CRC-URI partnered the Rhode Island Coastal Resource Management Council to initially evaluate the then-current condition of Rhode Island's coasts and to develop strategies for fisheries and beach conservation. In 1976, Rhode 
Island had the first Coastal Zone Management Plan under the ICM criteria. In the US, coastal management had unpacked political resistance among coastal resources stakeholders (Olsen et al. 2006). Mainly, while locals rejected central government initiatives, the central government rejected local initiatives. Later, the US-based CRCURI experiences demonstrated that ICM reduced the functional mismatches between different levels of government by promoting cross-boundary integration of government, community, the private sector, NGOs, universities.

In 1985, the CRC-URI partnered with the US Agency for International Development (USAID) to apply ICM pilot projects in tropical countries (Ochoa 1995). The goal was to introduce and experience ICM in countries with fragile governments, high levels of poverty among the rural population, and fast-paced changes in ecosystems (Olsen \& Christie 2000). Thus, Ecuador, Sri Lanka, and Thailand became ICM pioneers out of the US. By the year 1990, several other Latin American counties engaged integrated approaches to coastal management, among them: Costa Rica, Barbados, Mexico, Colombia, Peru, Brazil, and Chile (Olsen 2000). CRC-URI aimed to document challenges and means to achieve horizontal and vertical integration in coastal management. Furthermore, the CRC-URI Director, Stephen Olsen, became member of the Joint Group of Experts on the Scientific Aspects of Marine Environmental Protection (GESAMP), which joined experts from different UN offices (UNESCO-IOC, FAO, WHO, UNEP, and others) concerned on improving "the life of human communities who depend on coastal resources while maintaining the biological diversity and productivity of coastal ecosystems" (GESAMP, 1996, iv). Thus, CRC-URI projects became influential on ICM methodology improvement and promotion. 
According to Post \& Lundin (1996) ICM aims to encompass "all of the sectoral activities that affect the coastal zone and its resources and dealing with economic and social issues as well as environmental/ecological concerns" (1-2). Consequently, ICM's integral approach promotes spatial integration of the coastal zone (land and sea), horizontal inter-sectoral integration, vertical intergovernmental integration, interdisciplinary integration (science and management), and international integration, argue Post \& Lundin. Thus, ICM integrates objectives and management cycles (information collection, planning, decision-making, management, and monitoring) in a long-term process for sustainable management of coastal resources.

However, ICM goals, approaches, scopes, and findings vary considerably according to national and local management (Tang et al. 2010, 106). Indeed, "the very definition and delimitation of the coastal zone varies considerably among coastal States" (Meltzer 1998, 13). Thus, ICM practitioners must tailor strategies according to local processes while stakeholders must actively participate in elaborating and implementing versatile programs to manage coastal resources (Avellar et al. 2014, Olsen 2003, Arriaga 2000, Hap et al. 1997). Importantly, Elinor Ostrom's eight principles toward robust ecosystem governance guide tailoring ICM programs to "integrate" governance and management into coastal stewardship (Kearney et al. 2007, Ochoa et al. 2001, Olsen et al. 2006, Olsen et al. 2009).

ICM also adopted and developed adaptive management criteria toward sustainable coastal development (Olsen \& Christie 2000). Adaptive management of governance is a model developed by resilience ecologists that emphasizes to enhancing the self-organizing capabilities of an ecological system and improving locals' self- 
regulatory social mechanisms towards a successful adaptation (Berkes and Folke 1994, Berkes et al.1995, Berkes et al. 1996, Ostrom 1990 cited by Berkes 2006, Gadgil et al. 1993). Moreover, Kearney and colleagues argue that the role of the communities in management decision-making is vital for ICM because the communities know "what will work in a local situation" (Kearney et al. 2007, 86).

In addition, the CRC-URI introduced the criteria of nested institutions into coastal governance. According to Olsen et al. (2006) "governance should employ a mix of institutional types using a variety of decision rules to change incentives, increase information, monitor use and induce compliance" (47). Furthermore, Olsen (2003) emphasizes on a management-governance relation for tailoring strategies under local processes and needs:

“"governance' sets the framework within which management occurs, where 'management' is the process by which human and material resources are organized within an institutional structure (such as a protected area) for a known goal (such as fisheries enhancement or biodiversity conservation)" (Olsen 2003, $328)$.

To bridge top-down and bottom-up approaches to manage natural resources, ICM promotes a two-track strategy "by simultaneously and incrementally building capacity both within central government (both national and provincial) and at the selected geographic sites" (Hale 2000, no pagination). On the one hand, the ICM includes a topdown approach by which the central government enacts policies, procedures, and structures. On the other hand, a bottom-down approach "enable[s] change at the community level, site, and local government" (Hale 2000, no pagination). Thus, ICM's 
two-track strategy allocates responsibility and authority among governance levels: national, provincial, municipal and communities through a process of decentralization of power and decision-making. Consequently, the two-track strategy aims to build constituencies at both the national and community levels.

Furthermore, CRC-URI admits the two-track strategy can also be termed comanagement (Olsen 2000). Co-management "is one form of collective action whereby resource stakeholders work together with a government management agency to undertake some aspect of resource management” (Tompkins and Adger 2003, 8). Overall, comanagement aims participatory governance to allocate power in the different layers of management. According to Kearney et al. (2007), ICM's “participatory governance would involve a much wider sharing of powers than those shared in the management of coastal resources" (82). Similarly, Olsen states, "decisions should be made at the lowest level of society as is practical and consistent with the public good. This requires the allocation of power among several levels of authority" (Olsen 2000, 29). This "Subsidiarity Principle" entails a system for avoiding power and resources concentration in top levels of hierarchy and share the responsibility with those who experience the consequences of the decisions (Ochoa et al. 2001, Olsen et al. 2006, Olsen 2000).

$\underline{\text { An adaptive model of coastal resource management }}$

The integrated logic of coastal resource management proposed by Olsen and the CRC-URI includes cycles through which management adapts to achieve coastal resources sustainability. ICM applies Learning Cycles and Policy Cycles. According to Olsen et al (1997, 158) "adaptive management calls for learning by doing." Thus, ICM firstly applies 
Learning Cycles, or continuous cycles of action and reflection previously developed in organizational management (Olsen et al. 1997). According to Emilio Ochoa, an international ICM consultant who partnered Olsen in Ecuador (interview with author August 31,2018 ), learning cycles allow to defining issues, to creating constituencies, and to promoting stewardship of resources through five steps. The five steps of the learning cycle include: create awareness, assessing options, deciding practices, experiencing, processing outcomes (Olsen 2003). The learning cycles include a variety of participatory techniques on the ground, among them workshops, meetings, and practical exercises. In this way, ICM model evaluates effectiveness or ineffectiveness achieved to build local institutional capacity. The cycles of learning are permanent during the whole life of the ICM.

Learning cycles continuously feed the level of governance, which exclusively address resource management. ICM Policy Cycle entails: 1) Issue assessment, to understand how the country manages coastal resources; 2) Program preparation to define and set coastal resource management goals and correct legal, administrative, and financial deficiencies; 3) Formal adoption of ICM at national level governance to assure the legal foundation and operation; 4) Implementation of ICM policies in specific zones of coastal management, known as Special Management Zones; and 5) Evaluation of national and local outcomes (Olsen et al. 2009). Once reached the last step, another ICM phase starts.

Additionally, CRC-URI adaptive model of coastal resource management expects four level of outcomes. Callie et al. (2007) describe the outcomes as follows: First Order outcomes, include pre-condition arrangements to know the current environmental and 
governance situation of the coastal zone. Second Order outcomes focus on behavioral changes toward good practices, including decision-making, resource use, infrastructure/services, and local identity's strengthening through development opportunities. Accordingly, changes in behavior encompass institutions, user groups, and the public at large. Third Order outcomes harvest scalar changes in quality of life and environment. Ultimately, the fourth order outcome achieves sustainable societies. It includes sustainable resource use, social responsibility, legal framework, and ethical values.

\section{Integrated costal management in Ecuador}

By the 1980-1900, shrimp-farming reached to be one of the main Ecuadorian GDPs component. However, shrimp-farming, which started by the late 60s in Ecuador, had devastated large extensions of mangroves. By the mid-eighties, $26.7 \%$ of mangroves and $93 \%$ of saline areas (areas flooded once or twice a year by extraordinary tides) disappeared as a consequence of the shrimp industry (Pazmiño et al. 2018). In 1986, the Government of Ecuador signed an agreement to implement USAID's International Coastal Resources Management Program. The program was a ten-year initiative, implemented by the CRC-URI, "for testing whether the concepts and techniques of integrated coastal resources management that had evolved in the previous decade could be applied to developing tropical nations" (Epler and Olsen 1993). USAID particularly addressed tropical countries where "conservation and biodiversity protection [were] rarely foreseen in the political agenda; instead the priority is on economic growth and livelihood development" (Olsen 2003, 46). 
In Ecuador, the ICM project focused on rural and poor zones in the coast. These areas showed high levels of coastal deterioration due to climatological processes and, mainly, the expansive shrimp-industry. The main ecological concern was the high degradation of the mangroves. According to ICM approach, such natural and anthropic effects must inform to environmental policymakers to organize a more sustainable coastal resources management. Later on, the program extended its operation to protected areas, water quality issues, land use, ecology and environment, shrimp farming and aquaculture, construction on beaches, mangrove ecosystems, navigation, fisheries and tourism (Olsen et al. 2006). Consequently, the purpose of promoting ICM in Ecuador widened to conservation, restoration, protection and sustainable development of coastal resources in the Pacific coast provinces: Esmeraldas, Manabí, El Oro, and Guayas (which included Santa Elena region before the year 2007). According to Olsen (2003), by the year 2001 the CRMP fulfilled a whole policy cycle. The following subsections briefly explain each step of the completed phase one policy cycle, locally known as CRMP I.

\section{$\underline{\text { Issue assessment }}$}

At the national level, the pilot project was initially charged to understand issues in Ecuadorian coastal management by collecting national legal frameworks on coastal management and by inventorying ecological, social and economic data in the Ecuadorian coast. The CRC-URI issued the document "A Profile of Ecuador's Coastal Resources" (Epler \& Olsen 1993), which compiled the conditions of the Ecuadorian management of coastal resources. 


\section{$\underline{\text { Program preparation }}$}

Initially, the project defined the coastal zone in Ecuador; it circumscribed the highest tide line up to $50 \mathrm{~km}$ inland._The previous phase entailed active and participatory networking, from the seaside villager to the top-ranked government official, while a main office located in Guayaquil, the main coastal city of Ecuador, bridged such broad network. The project engaged leaders from across the political spectrum - including government, industry, academia and so on. They signed a manifesto in support of coastal management in Ecuador. Thus, the country was ready for formally adopting and institutionalizing a coastal management program.

\section{Program formalization}

Under the name Programa de Manejo de Recursos Costeros or Coastal Resources Management Program (CRMP) the Ecuadorian government formalized the ICM initiative in 1989. The Executive Decree \#375 established the creation of a National Commission of Coastal Management, an Executive Directorate, Units of Conservation and Vigilance (UCV), 6 Special Management Zones (SMZ), while the office in Guayaquil became the center of operations.

In 1992, the Executive Decree \# 3399, restructured and decentralized the CRMP, giving to the Executive Directorate considerable autonomy while the National Committee retains the individual authority and responsibilities on resource management policies (Olsen et al. 1997). In doing so, the ICM program in Ecuador was ready for the 
implementation phase of the Policy cycle, which required a different, non-USAID, financial assistance.

\section{Program implementation}

USAID supported Ecuador in looking for funds for implementing an integrated coastal management. In 1994, the Inter-American Development Bank (IDB) approved a first loan for funding the CRMP (US\$14.9 million through the Loan 913/SF-EC). Consequently, the government of Ecuador took the whole administration of the program, while previous members of the USAID-CRC-URI pilot project became consultants for a couple of years more. Transitioning from the USAID-CRC-URI program to the IDB Loan management worried ICM promoters. The primary concern was on the capacity to "maintain a dedication to an adaptive and participatory approach to resource management" (Haq 1997, 285) and to continue building coastal management upon the integrated coastal management values.

At the local level, CRMP I promoted the ejercicios prácticos de manejo integrado or practical exercises of integrated management in all SMZ, under the logic of the learning cycle (Rodadue 1995). They are mini cycles applied at the local level, which fed the ICM learning cycle, the management cycle of adaptive governance. Experts worked together with locals in developing an appropriate methodology by experimentation.

"People gave their ideas, the program put them in practice" comments Emilio Ochoa, one of the main CRMP promoters in Ecuador and Latin America (Interview with author August 31 2018). Robadue (1995) reports two practical exercises in Santa Elena: 
Lifeguard group formation and equipment in Montañita beach continually operated by three years and a center for shrimp larvae collection in Valdivia, which did not start operations. Similarly, Arriaga (2000) reports the experience of improving the nets for capturing wild shrimp larvae, shell farming, and experiments on mangrove reforestation (Arriaga 2000). Zambrano (2011) additionally reports a failed case of community-based tourism initiative in Libertador Bolívar.

Arriaga (2000), former CRMP director, highlights the opportunity CRMP gave to the people of the rural coast, mostly illiterate and poor, to participate in decisions and actions toward social and economic development. They participated in cross-level committees that CRMP created looking for best coastal resource management. Coastal rural people had never had this opportunity before CRMP achieved to build local capacity by participative collaboration and learning-by-doing. Small projects were crucial for planning local management and for building local audiences (Olsen et al. 1997).

In Santa Elena, the first coastal management plan was ready in 1993. The plan included five components: environmental sanitation, aquaculture, fishing and tourism in the Manglaralto Parrish, northernmost parish of the area. Regarding tourism, the plan had clear outlines including beach zoning, tourist peak season's management, communitybased hostels, and technical training on food manipulation and customer services. Beach ordering also included carrying capacity measurement, because one of the main issues was the unequal distribution of visitors during the peak season (January to April), and the damage that a large number of visitors produce to the beach system. The CRMP also aimed to reduce beach damages by diversifying tourist services - out of sun and beach 
options. CRMP worked next to the Ministry of Tourism to create and operationalize inland ecological routes, such as Dos Mangas in Manglaralto and other routes less demanded. Nowadays those initiatives continue being main tourist attractions in Santa Elena. The CRMP also articulated socio-organizational processes in order to preserve natural resources and promote economic activities in the aftermath of the 1997-1998 El Niño Phenomenon.

Since its origin, the pilot project included the Manglaralto Parish within Special Management Zone. In this area, CRMP trained several community leaders and initiated self-employment alternatives after the shrimp larvae and the shrimp farming industry decreased in the late 1990s. A report from the Rural Promotion Center (CPR-AeA 2014) reveals that in 1998, the CRMP announced its annual operative plan, which included financial resources for workshops, implementation of tourist hostels, and tourist promotion. To develop the project, CRMP hired Fundación Pro Pueblo, a private nonprofit organization funded by the Swiss HOLCIM group. From 1999 to 2001, the CRMP chaired the Zonal Committee, which, mainly, regulated tourism development processes of the communities located on the edge of the Pacific Ocean. In coordination with other institutions, beach cleaning, road cleaning, and water supply were carried out. The CRMP also financed tourism promotion through the opening and closing seasons events, and control prices and the offer of community hostels (Zambrano 2011).

\section{$\underline{\text { IDB assessment }}$}

CRMP I also achieved second order outcomes, which entails "changes in behavior of institutions and stakeholder groups; changes in behaviors directly affecting resources 
of concern; and investments in infrastructure (Olsen 2003, 26-33). Caille et al. (2007) assert, the CRMP project achieved good decision-making and good practices on effective resource uses. Indeed, a report collecting eight years of ICM in Ecuador states:

"CRMP [...] has encouraged local populations to perceive themselves as part of the ecosystem and to attempt to resolve environmental and social issues within this context. Some user groups whose existence depends on accessing or exploiting a given resource, are being educated on the implications of resource exploitation. They are learning to accept responsibility for their actions and to consider alternative actions on management efforts that will increase the value and/or sustainability of their activity." (Robadue 1995, no pagination)

Local training and teaching became a crucial strategy to achieve the second order outcome. For instance, Olsen (2003) asserts "CRMP also builds individual capacity through education and training" (51). Training particularly addressed awareness of the benefits of natural resources and understanding the systemic integration of environment within several subsets of ecological, social, economic systems. For instance, CRMP raised locals' consciousness on sustainable use of resources and some side effects of local practices such as shrimp-larvae capture by-products and estuarine systems importance through the methodology of practical exercises.

Regarding the Third Order Outcome, the program achieved social and environmental goals. Particularly on social system, Olsen $(2003,114)$ states: 
"The biggest, but unquantified, achievements were undoubtedly in the generation of hope and empowerment-important indicators when assessing quality of lifethat the CRMP process brought to the poorer segments of coastal society"

In addition, the CRMP phase I contributed to protecting and preventing further deterioration of mangrove. However, efforts did not achieve environmental quality improvement. Former ICM promoters and practitioners admit CRMP failed in creating a clear policy on integrated management despite having completed a policy cycle.

Particularly because the IDB loan conditions "contradicted the fundamental strategies of the program, put carefully nurtured relationships at risk, and proved impossible to meet," argues Olsen $(2003,115)$.

The IDB evaluation also revealed CRMP had not completed the quality and the activities depicted in the agreement. For instance, eco-tourism was "attracting few visitors and were beyond the capabilities of the local volunteer environmental groups to administer or maintain" (Olsen 2003, 108). However, the 1990s natural disasters and political instability justified CRMP's failure. In the coast, the 1997-1998 ENSO surpassed the 1982-1983 event, causing damages over two million dollars. At the national level, presidential impeachments and relinquishments, the war and peace agreement with Peru, and the loss of the national currency pervaded the 90s. Thus, the IDB agreed to embark in a second loan for spreading coastal sustainable development to other sites in the coast of Ecuador. 


\section{Ecuadorian coastal resource management program phase II}

CRMP I, particularly under the CRC-URI advising, have been broadly documented. Various working papers, academic journals, and books on ICM developed in Ecuador exist, mainly published by the CRC-URI. On the contrary, the second phase of CRMP - after a second IDB loan, has not called attention to scholarship in general, and ICM practitioners in particular. In this section, I trace the second phase of CRMP, through which I pursue an overarching analysis of ICM in Ecuador.

After the first loan evaluation, the IDB demanded new requirements for signing a new contract. In response, the Ecuadorian government issued Executive Decree No. 772 on August $23^{\text {rd }}, 2003$. This decree provided to the CRMP exclusive management of IDB agreement. On October 26, 2004, the IDB and the government of Ecuador signed the Credit 1531 OC/EC. As stated in the agreement, IDB borrowed US\$12,400,000 while the Ecuadorian government would provide two million dollars to complete the total cost of the project. Overall, the second phase (CRMP II) aimed to transfer a total territorial consolidation of coastal ordering as CRMP I achieved in the special management, to implement sustainable development and poverty alleviation in all coastal cantons (131 total).

CRMP main office and director continued bridging the national and local governance. At the national level, CRMP II became an interlocutor of all activities the ministries of Environment, Fishery, and Tourism undertook in the coast, argues Paola Galvez, former Tourism Undersecretary (interview with author June 14, 2018). Similarly, Victor Osorio, former CRMP II Director asserts, “CRMP II was an axis among the Ministries [Environment, Fishery, Tourism] to discuss and make consensual decisions on 
the coastal area despite having different local management goals and actions" (Interview with author July 11, 2018). Thus, CRMP II integrated the ministries in coastal management issues.

At the local level, CRMP's scope of action widened. CRMP II included environmental and development programs toward sustainable development of the coastal villages. In Santa Elena and other beaches, CRMP II promoted and executed several environment-related activities, among them: garbage management, sanitary landfills, drinking water, cliffs stabilization, mangroves reforestation, fishing ordering, beach cleaning, and beach safety, and also development first risk maps. However, CRMP II emphasized small-scale developments, including marketing and promotion.

CRMP II increased the Hospederias Comunitarias or Community operated hostels, as a way of developing the community as a whole. Similarly, CRMP promoted privately owned restaurants and handcraft shops. Seaside villagers worked together with CRMP II technicians and government staff in designing and building projects, as they were used to doing since the previous CRMP I. According to Osorio, CRMP II director, seaside villagers actively participated in decision-making processes or during the construction of their small-scale business; thus, projects emerged by consensus with locals. Thus, CRMP's human-centered and participatory approach kept vital in the development of coastal rural communities, under the flag of environmental issues and poverty alleviation.

To execute all those programs and projects, CRMP II contracted private consultants and partnered with NGOs. Consultancy primarily devoted to environmental issues, constructing public restrooms, latrines, cleaning beaches, managing solid waste. 
In the case of tourism initiatives, private consultants produced marketing material and a few advertisements within the country. Similarly, NGOs and private consultants provided a variety of technical workshops for improving tourist business. Workshops addressed to notions of accounting, taxation, food and beverage business operation, and so on. Interestingly, IDB agreement established a limiting clause for providing funds. In line with the agreement, CRMP II can finance up to $80 \%$ of locals' project. Locals had to contribute at least $20 \%$ of project's total cost. Such contribution was not wholly in cash. Mostly, locals interested in developing small projects contributed with direct labor or with local materials provision. Thus, CRMP projects pursued securing seaside villages' economic survival while participation and training continued a way to improve comuneros' local capacities.

The analysis of CRMP II also reveals controversial outcomes among participants. High-ranked government staff agrees in the success of the program. For instance, Paola Galvez, former Tourism Undersecretary (interview with author June 13, 2018) points out that numerous families transformed their homes into hostels supported by technical and financial assistance provided by NGOs under CRMP II strategies. Additionally, CRMP II introduced concepts on planning, beach carrying capacity, beach management plans, and beach zoning, achieving a clear distinction between fishing and tourist communities in the coast of Ecuador, states Veronica Sion, former Ministry of Tourism (interview with author June 19, 2018). CRMP II Director, Victor Osorio, asserts,

“CRMP II's best achievement was to empower coastal communities to go in search of sustainable development, in a time when municipalities did not have 
financial availability, and rural areas were barely included in the national budget" (interview with author July 11, 2018).

Overall, in the tourism field, CRMP II successfully built and financed tourism facilities and small-business underpinning comuneros' opportunity to become tourist services providers. Nowadays, many owners of successful hostels, restaurants, and handicraft shops acknowledge and thank CRMP II project for improving their quality of lives and economy. This new economy allows locals to progress, and, currently, be a benchmark for new generations of local entrepreneurs.

Conversely, sharp critiques of CRMP II also appear. For instance, the president of an NGO operating in the area since 2003 critique CRMP II's excessive developmental criteria while appreciates more CRMP phase I, because it "really promoted sustainable development in the coast of Santa Elena" (Isabel Cando, interview date June 21, 2018). Furthermore, CRMP II projects “were not locals' own needs; instead, they were persuaded needs the community leaders embraced," argues Cando. Additionally, Emilio Ochoa (interview with author August 31, 2018), ICM expert in Latin America, argues that CRMP II became a project for poor people who needed assistance of any kind. Similarly, Efrén Mendoza, former CRMP staff in Santa Elena, critiques CRMP II because it became "a paternalistic project" and "a building machine" (interview with author June 22, 2018). Overall, Mendoza argues, CRMP II “reduced locals' active participation while locals became passive recipients of project." The critique of CRMP II reveals a distant programming of coastal sustainability while locals became recipients of designed projects and active workshops attendees. Thus, CRMP II took into account locals needs, ideas, and projects. However, CRMP II operated through consultants and 
partnering NGOs for detecting "issues" and strengthening "constituencies" toward sustainable coastal development technicians analyzed and decided in a distance what they consider the best for locals. Thus, locals' participation in decision-making turned into accepting what CRMP II brought to the community.

The Blue Flag Certification project instantiates CRMP II's critique. In 2006, CRMP II together with the Ministry of Tourism aimed to implement an international beach certification called Blueflag (www.blueflag.global/). Blue flag is an eco-label awarded to beaches that reach environmental, educational, safety, and accessibility criteria. In Santa Elena, the program selected the comuna Libertador Bolívar to participate in such certification. Community Assembly logbooks collect discussions about this project. The tourism committee in Libertador Bolívar highly promoted the beach certification. Thus, the comuneros contributed to providing a land slot at village's south entrance. In this plot, CRMP II built a tourist information facility. Locals also participated by cleaning the sandy beach, improving garbage management, improving tourist services, and so on. However, the beach of Libertador Bolívar never reached the certification. The legal framework for beach management in Ecuador was and continues being unclear. The office built in Libertador Bolívar, is currently rented to a private paragliding operator, while locals still keep the hope of getting a beach certification. Furthermore, the national tourism ministry has unsuccessfully proposed a beach certification normative. Under the ICM approach, those failed projects feed the policy cycle. However, during CRMP II, ICM learning cycles did not accomplish the goal to provide feedback to environmental policymaking, neither at the local nor the national level. 
At the national level, CRMP II integrated coastal development issues among the three Ecuadorian ministries. Consequently, the "integration" came from the sectorial coordination but distanced from the ICM's adaptive approach and learning cycles. In addition, IDB officials supervised CRMP II operations while international consultants annually assessed the coastal management plan. In 2008, the CRMP II merged with the Ministry of Environment. According to the Executive Decree No. 1254-2008, the CRMP did not report, "real benefit" neither "transcendent importance" in coastal areas. The CRMP merged to the Ministry of Environment in the midst of radical changes the newly inaugurated anti-neoliberal government introduced in Ecuador. The left-led government highly critiqued the neoliberal way of ruling the country, including governmental interventions on sustainable development and disaster management.

\section{Integrated coastal management legacy in the coast of Ecuador}

In twenty years of CRMP, the program achieved an unprecedented challenge

(Table 3). The program developed government structures, coastal management policies, and models, analysis of marine-coastal areas, control and surveillance systems; school curricula including notions of ICM; tourism, fishing, agricultural, and environmental micro-projects; and risk prevention efforts. Former CRMP executives and technicians agree that the project achieved sustainable development of the coastal areas of Ecuador while locals got a commitment aiming a harmonious flow between nature and the reality in which they live. However, the CRMP never achieved a state policy level. 


\begin{tabular}{|c|c|c|}
\hline & CRMP I & CRMP II \\
\hline Phase & $1986-2003$ & $2004-2008$ \\
\hline $\begin{array}{l}\text { Initial } \\
\text { situation }\end{array}$ & $\begin{array}{l}\text { - No existence of integrated } \\
\text { management of coastal } \\
\text { resources policies. }\end{array}$ & $\begin{array}{l}\text { - No clear policy on integrated } \\
\text { management of coastal } \\
\text { resources }\end{array}$ \\
\hline Priorities & $\begin{array}{l}\text { - Ecosystem Degradation } \\
\text { - Mangrove Ecosystem } \\
\text { degradation } \\
\text { - Aquaculture opportunities } \\
\text { - Health problems and quality of } \\
\text { life in coastal populations. }\end{array}$ & $\begin{array}{l}\text { - policies for development of } \\
\text { coastal communities }\end{array}$ \\
\hline Outcomes & $\begin{array}{l}\text { - Failed attempts to create an } \\
\text { integrated management policy. } \\
\text { - Administrative structure } \\
\text { achieved at the national level } \\
\text { - Zoning of coastal areas to } \\
\text { coordinate actions among } \\
\text { national ministries. } \\
\text { - Active participation of citizens } \\
\text { living in seaside villages }\end{array}$ & $\begin{array}{l}\text { - } \text { Training local governments on } \\
\text { IMC } \\
\text { - Focus on municipalities } \\
\text { strengthening decentralization. } \\
\text { - Weakness in the canals of } \\
\text { citizen participation }\end{array}$ \\
\hline
\end{tabular}

Table 3 Coastal Management priority concerns, administrative organization and results. Elaborated by Author

The CRMP introduced in Ecuador a coastal management approach based on the integration of environmental and development issues. The integrated coastal management methodology promoted the idea of building more sustainable communities by suitable resource use. The book titled "Ecuadorian Integrated Coastal Management. Beachhead towards a Coastal Sustainable Development" (Arriaga 2000) acknowledges the influence of UN's concern on global resource threats and the integrated condition to address issues emerging from human-driven management of natural resources. According to Arriaga, an ecological vision and citizens participation are ICM foundations. Furthermore, the said 
book asserts, ICM embraces Eugene P. Odum's structural and functioning interdependence of ecological systems. Accordingly, such approach integrated human beings, powerful agents to introduce significant changes in natural processes (Arriaga 2000, 61).

The ICM methodology emphasized learning cycles informing policy-making cycles. Indeed, CRMP during the late 80 s and early 90 s entailed effective integration of technicians and government staff, working together in coastal management with local villagers' active participation. CRMP officials achieved to formalize IMC at the national government. Meanwhile, coastal villagers found in the CRMP strong support to improve their own ideas. In doing that, the ICM two-track strategy achieved to change the behavior of the coastal villager, second order outcome. Overall, CRMP I unpacked the virtue of reliance on local villagers' capacities and resources while moving away from capitalist strategies of coastal resource management and use, such as extensive shrimp farming.

Conversely, during CRMP II, the idea of "development" was stronger than the idea of "sustainability." A criterion also adopted among the coastal population, including rural villagers and local government. In other words, as Julian Reid (2018) argues, sustainable development "reflected a neoliberal political agenda" (p. 647) that "shifts the burden of security from states to people" (647). Thus, CRMP promoted to secure life from the economy "through the promotion of capacities of life for economy" (652).

CRMP II operated similarly to a development agency, following IDB's guidelines. Consequently, the CRMP II emphasized in poverty alleviation by providing locals with both small-scale environmental solutions (latrines, pipelines, and so on), and 
funds for building infrastructure (particularly tourism services). In doing so, the program distanced from what ICM implemented almost two decades before. ICM ejercicios prácticos did not work anymore. Instead, funded projects replaced the ejercicios prácticos. Without practical exercises, no learning cycle fed the policy cycle. Consequently, the adaptive governance promoted by ICM disappeared. In doing so, CRMP II distanced from what ICM implemented almost two decades before.

Unquestionably, after two decades of CRMP in the coast of Santa Elena, the way of living in rural coastal areas changed. A few families inland subsist through small agriculture, fishing, and even shrimp-industry wage labor dependency. Tourism is the new desire for progress and a better future. They built their cabanas with local material, resources and ideas. Moreover, self-employment is a new opportunity for villagers. They bet on small tourist entrepreneurship, in which their family and the community work together while the beach has become the most appreciated resource.

\section{Conclusion: a connected but distinct genealogy of resilience in Ecuador}

The mutual contribution of ICM scholars to the UN's global concern on coastal resources concerns have been discussed in this chapter. ICM rooted in Eugine P. Odum's contributions to ecology and adopted concepts on co-management toward the sustainability of coastal areas. Firstly, resilience in ecology admits the socio-ecological relationship. Similarly, the ICM methodology developed by CRC-URI, acknowledges the socio-ecological interplay in coastal zones. Secondly, the ICM also emerged as a critique of the one-size-fits-all resource management panaceas. Instead, ICM emphasizes 
tailoring coastal management according to local necessities through the Two-Track strategy.

Furthermore, ICM developers admit the two-track strategy renders adaptive governance. Indeed, ICM incorporates the role of social institutions into coastal environmental management and participatory governance to allocate power in the different layers of management. However, CRC-URI's ICM practice emphasizes in "management" as a process to organize the human and material "resources." A coastal management that requires national juridical-political frameworks. Moreover, ICM's twotrack strategy practiced in Ecuador achieved the four Adaptive Governance features proposed by Carl Folke (2006), resilience in ecology influential scholar (see chapter 2). Thus, ICM in Ecuador started by understanding the then-current situation of coastal ecosystem dynamics, applied participatory techniques to interpret Ecuadorian coastal ecosystem feedbacks, built capacities within the national and local government, and built constituencies at both the national and community levels.

However, CRMP emphasis was the securitization of locals' economy through the appropriate "management" of the coastal areas. Thus, ICM in Ecuador promoted a preventive logic that locates security responsibility on the population and individuals. In Santa Elena, CRMP promoted entrepreneurship among the comuneros to secure their livelihood. In doing so, ICM partners other mechanisms of security that regulates the social and ecological relationship, such as resilience-building. Furthermore, CRMP responded to international agencies largely critiqued by their neoliberal practices, such as USAID and IDB. In a similar vein, resilience building has also been critiqued for responding to neoliberal governmentalities. After twenty years of CRMP, Ecuador has a 
financial debt to IDB while in Santa Elena, comuneros integrate the tourism industry pursuing sustainable development and economic securitization of the population. 


\section{CHAPTER VI}

\section{Local emergencies and the politics of resilience}

Many rural seaside villages in Ecuador have adopted small-scale tourism development in the last three decades. Particularly in the province of Santa Elena, this tourism-led economy emerged from governmental concerns on coastal resources management, highly promoted during the 90s (Chapter 5). By the year 2019, the smallscale tourism industry in Santa Elena secures communities' livelihoods while the beach has become the most valuable resource for comuneros' economic survival. Beaches in Santa Elena, now a natural resource that visitors enjoy, have been exposed to numerous anthropic interventions to improve tourism development. Those interventions in Santa Elena's beach ecosystems do not exclusively respond to governmental interventions. Instead, the comuneros decided and mediated numerous tourist initiatives because according to them, the tourism industry brings progress and wellbeing to the whole community, as this chapter reveals. This chapter particularly discloses comuneros' social organization on local tourism development within the functioning of the state.

However, despite national and local efforts to improve tourism in coastal villages, small and chronic disturbances persistently threaten the local tourism-led economy. Firstly, Ecuadorian governments have promoted tourism development on the rural coast without reaching a legal framework according to rural realities. In those legal interstices, the comuneros deal with mis-recognized events that put their economic survival at risk. Most comuneros operate their tourism businesses with mismatches between risk 
management and tourism development policies. Secondly, a chronic but small natural threat is also putting comuneros' livelihood at risk. Waves are increasingly battering the beaches and are unpredictably destroying the tourist infrastructure that underpins the local economy. Thus, on a daily basis, comuneros are prone to small, local, chronic events (Anderson et al. 2019, Davoudi 2012, Povinelli 2016) that disturb the very nature of their comuneros-beach relationship In this chapter, I untangle persistent perturbations emerging from both legal mismatches and local decision-making on the beach, a common property resource in the seaside comunas of Ecuador.

In the first section, I trace tourism policies development in Ecuador, emphasizing community-based tourism. During the 1990s, governments ruling the country under neoliberal practices introduced and promoted community tourism in Ecuador, particularly in common-property territories. Community tourism fits within the anti-neoliberal rationale of the leftist government that ruled Ecuador since 2007. Thus, the leftist government strengthened community tourism as an alternative model of market-driven logic of development. However, a lack of a comprehensive legal framework to regulate tourism in common-property territories still persists. This local reality complicates comuneros' tourist development while opening interstices for illegal tourist operation in rural areas.

The second section analyzes comuneros' decisions over the use (and abuse) of the beach as a natural resource underpinning community wellbeing. In doing so, I locate my research in the comuna or community of Libertador Bolívar, one of the few Santa Elena communities that has maintained total administration of their territory. I trace tourism development and decisions comuneros have taken about the use of a shared resource: the 
beach. By capturing quotidian disturbances of the comuneros-beach relationship, I disclose slow emergencies (Anderson et al. 2019) comuneros endure while pursuing community wellbeing. The third section of this chapter discusses comuneros' chronic events under the light of slow emergencies, a notion introduced by Anderson et al. (2019) to highlight those non-punctual, non-acute emergencies, which also demand collective political or ethical response. However, in the case of Santa Elena, the use (and abuse) of natural resources, individuals living in the interstices of national policies, and governmental logics aimed at securing future wellbeing, configure dynamic and continuous subsets of political processes within the endless and complicated human-innature relationship. Consequently, comuneros' slow emergencies should entail novel approaches to the politics of resilience.

\section{Neoliberal and anti-neoliberal tourism development management in Ecuador}

Ecuador is a politically unstable country. This situation complicates national policies and administration longevity. Thus, changes in governmental decision-making on national development stresses local initiatives in different ways. In this section, I analyze the national administration of tourism development in Ecuador to understand the local struggles comuneros have undertaken to develop small-scale tourism in commonproperty territories.

In the last three decades, the tourism industry in Ecuador has successfully expanded. According to the Ministry of Tourism, tourism achieves to being GDP's third non-oil exportation income and the fifth job-contributing industry. Ecuadorian attempts 
to improve tourism management in the country date back to the $50 \mathrm{~s}$ when the government created the first tourist office to marketing the country in the US. However, it was during the 1980s that Ecuador experienced a significant expansion of the tourism sector.

Thus, responding to trends on modernization during early 90 s (see chapter 4 ), the State created the Ministry of Information and Tourism in 1992. Three years later both units split, positioning tourism management in the Ministry of Tourism (MT). MT's primary goal was to address the legal tourism framework in a time when decentralization was a state. In 1997, the country enacted both, 1) the Special Law of Decentralization of the State and Social Participation, and 2) the first law of tourism. The first one transfers tourism development to municipalities (Art. 9, item n), and the second one explicitly aims to decentralize Ecuador's tourism management. Then, the main goal of MT was to develop the tourism industry in the country. In 1999, MT issued the National Tourism Competitiveness Plan, which, according to Ordoñez \& Marco (2005), proposed to foster a tourism development model compatible with international sustainable development trends, which respond to conservationist and poverty alleviation criteria. However, the centralist and national scope of the plan slightly mentions the participation of local governments, highlight Ordoñez and Marco. Nevertheless, the decentralizing process on tourism management continued in the following years of neoliberal practices ruling Ecuador.

In hand with the neoliberal rationality, the Ecuadorian government reinforced tourism management decentralization. After tourism became a national policy in 2001, the Ecuadorian government signed a loan contract with IDB for supporting decentralization of tourism. From this contract emerged the Programa para la 
Dinamización del Turismo or Program for Tourism Dynamization and the Acuerdo para la Transferencias de Competencias Turísticas or Tourism Competence Transfer Agreement. The goal of both IDB-funded programs was to operationalize tourism management decentralization in the country. The Ecuadorian government's main goal was to transfer decision-making power on tourism management to the local level of administration. MT would provide to the municipalities technical assistance to improve tourism management while the municipalities would manage tourism development in coordination with the national entity. By the year 2002, MT had signed agreements with sixty municipalities, among them the three cantons at the Santa Elena peninsula. However, the legal framework did not endorse a complete decentralizing process.

The anti-neoliberal practices implemented after the year 2007 addressed the legal disconnections inherited from the neoliberal period, through the subsidiary principle, stated in the 2008 Constitution and the General Code of Territorial Organization, Autonomies, and Decentralization (CTOAD), a central legal framework issued in 2010 to operationalize the constitutional dispositions (See Chapter 3). The subsidiary principle addresses decentralization by de-concentrating the roles of the state into the Autonomous Decentralized Governments (ADG). The CTOAD decentralizes and de-concentrates several responsibilities and roles to the provincial, municipal, and parish levels. Local tourism management is one of those decentralized responsibilities. Thus, article 54 states municipal ADGs must promote and control tourism development in the canton in an appropriate coordination with parish ADGs.

Similarly, Art. 64 designates to parish ADGs the responsibility of promoting solidarity economy models, including tourism initiatives, in coordination with municipal 
office. In the year 2012, the anti-neoliberal government issued a plan for improving main economic production sectors by which Ecuador prioritized tourism, among other industries. However, as I show in the following sections, legal mismatches persist regarding tourism management in Indigenous and rural territories.

Tourism in Indigenous and rural common-property territories

Indigenous and rural communities, mostly living in commonly owned lands, have managed tourism initiatives since the 90s. They gathered in the Federación Plurinacional de Turismo Comunitario del Ecuador or Ecuadorian Plurinational Federation of Community Tourism (EPFCT) to circumvent conflicts with private tour operators before the State legalized community tourism. In 2002, the updated Law of Tourism endorsed tourism initiatives operated by Indigenous and rural communities, and EPFCT became a member of the National Tourism Advisory Board. After this resolution, community tourism exponentially grew. A statistical analysis done by Morales-Urrutia et al. (2017) shows that community tourism significantly increased from eight initiatives registered EPFCT in 2004 to sixty-five, by the year 2006. In this year, the Equator Initiative, the UN Development Program, awarded EPFCT with the Equator Prize, a biennial award to recognize outstanding community-based efforts to reduce poverty through the conservation and sustainable use of biodiversity (UNDP 2012).

Overall, EPFCT became a hallmark for Community-based tourism (CBT) initiatives promoted by the UN Development Program. CBT is a locally based tourism that brings income directly to local families and subsidizes their sustainable way of life 
(Wesche and Drumm 1999). This typology of tourism became a flagship for pro-poor tourism strategies and development projects in the $80 \mathrm{~s}$ and $90 \mathrm{~s}$. Thus, under poverty alleviation, environmental conservation, and sustainable development rationales, international donors globally spread CBT projects in developing countries. A key feature of CBT relies on diversifying locals' economy. The multi-sectoral approach of CBT does not aim to display locals' livelihood. Instead, tourism becomes an additional activity to improve locals' wellbeing. In addition, CBT involves the participation of the whole community and the equitable distribution of income among all community members. However, after two decades of tourism management in Indigenous and rural communities, a particular structure known as Community Tourism has become an alternative to global CBT paradigms in Latin America in general, and Ecuador in particular.

In Latin America, Community Tourism (CT) furthers CBT's intimate link to sustainable tourism goals. According to Cabanilla (2018), CT in Latin America is indeed a locally based management model organized in groups of individuals intimately linked to sustainable tourism goals. However, the Latin American CT mainly aims positive cultural and natural impacts on their territories while pursues community members wellbeing (Cabanilla 2018). In Ecuador, EPFCT embraced CBT since the 90s; however, EPFCT's official position "situates tourism as a means to protect communal resources, including defending territory, while also promoting the visibility of alternative (native) cultural forms" (Bauer 2018, 125). Thus, CT in Ecuador strengthens shared values and practices rather than exclusively focusing on foreign concepts of sustainability of resources and development. 
Furthermore, the Ecuadorian common-property regulation has influenced the community-based tourism model. The 1937 Law of Communes codified in 2004 (O.R. 315-2004) mandates that communal assets and lands "will be the patrimony of all their inhabitants" (Art. 7). The use and enjoyment of common assets "will be adapted, in each case, to the best convenience" of each community, through regulations "autonomously and freely decided," also states the law (Art. 7). Thus, in the community assembly, locals discuss and decide over any tourist project externally or internally proposed. In doing so, the community keeps control over their communal territory and resources.

Decades of CT practice in Ecuador also reveals that communities seldom achieve the integration of the whole community in $\mathrm{CBT}$ projects or rigorously distribute its revenues with the whole community. Ruiz Ballesteros et al. (2008) trace the development of CT in Ecuador by contextualizing the economic effect of tourism, both in the logic of the community reciprocity and in the logic of relations of the market. Ruiz Ballesteros et al. argue that the endogenous tourism initiatives in Ecuador have endorsed commonproperty land and resources management, have vindicated the community's social practices of decision-making, and have reinforced autonomy and political consolidation of Indigenous communities. Moreover, CT complements the economic functioning of the community. The communities keep other forms of subsistence such as small-scale agriculture or fishery. However, CT complements economic diversity, which is a safeguard for the communities' livelihood (Ruiz Ballesteros et al. 2008).

Moreover, in Ecuador, each community manages tourism management and revenues distribution according to their own decisions. For instance, Salango, a seaside community in the south of Manabí (north Santa Elena Province), completely manages 
community tourism business and revenues (Bauer 2018). In other cases, the community collects fees from locally owned small-scale tourism businesses. They include local family or individually owned entrepreneurship and legal associations as well (Roux 2013). In the case of Santa Elena, communities admit community-based and privatelyowned tourism business. While the community manages the CBT business and its revenues, the comunero owners of businesses pay fees to the community.

However, financial liquidity has been and continues threatening CT development in the country. Most of CT initiatives in Ecuador started through an international or national sponsor, which provided funds for building tourist infrastructure, technical training, or promotion. Unfortunately, NGOs' projects, in most cases, conclude after a couple of years and new financial struggles appear in CT-led communities.

Community tourism fitted into the anti-neoliberal rationale of promoting alternatives to neoliberal practices of development. Thus, the 2009 National Plan of Development, prioritized tourism industry while ecological biodiversity and cultural heritage became allies to develop a national tourism agenda (Ministerio de Tursimo 2010). The first step to improving tourism in Ecuador was the inclusion of the right for leisure in the 2008 Constitution. In this sense, the anti-neoliberal rationale of the leftist government in Ecuador rejected capitalist over-exploitation of labor, overlooked during the neoliberal state practices in the country (Ramírez 2013). After the enactment of the right to leisure, domestic tourism increased. More and more Ecuadorians used the improved national road system to travel within the country. 
Throughout the country, the anti-neoliberal governmentality also addressed the financial liquidity issue affecting the local initiatives on tourism. For instance, the State financial corporations Corporación Financiera Nacional, Banco del Pacífico, and the Banco de Fomento created the Plan 5-5-5. This financial program particularly focused on those excluded from the commercial bank requirements, such as Indigenous and rural Community Tourism developments. The Plan 5-5-5 provided $\$ 5,000$, to be paid in 5 years with a $5 \%$ interest rate. In parallel, the Ministry of Tourism operated the program Turismo para Todos or Tourism for All, which trained small-scale tourism business owners for accessing the Plan 5-5-5. In the year 2008, I participated in this program by training small tourism business owners in cash-flow and budget management in several coastal communities. As a result, several CT initiatives applied and got such funds for improving their tourism businesses. However, the CT legal framework was yet unaddressed.

In 2010, the government issued the regulation for the Centros de Turismo Comunitario (CTC) or Tourism Community Centers, conditioning its management exclusively to the community (O.R. 154-2010). This law requires that CTC must have formal legal status. The regulation also acknowledges private or family-owned tourist businesses in the communities. However, "they must respect and subordinate to community norms regarding the use and management of the tourist attractions, and they will be registered in the Ministry of Tourism," states Article 5. Later, the Ley de Tierras y Territorios Ancestrales or Law of Lands and Ancestral Territories (O.R. 711-2016), issued in 2016, also endorses the Ecuadorian model of CT. Articles 3 and 23 provide to the Community Assembly and the Cabildo the management and social control over the 
territory, based on the uses and traditions of the community. Furthermore, Articles 23 and 78 also state tax exceptions to the communities.

Overall, anti-neoliberal practice supporting CT in the country increased local initiatives. By the year 2012, EPFCT doubled the projects, registering 135 projects (Morales-Urrutia 2017). This number increased to 137 in 2015, the same article reports. Worthy of mentioning, the statistics documented by Morales-Urrutia, show $10 \%$ of CT are operating (consolidated programs), $44 \%$ are in the consolidation process, $30 \%$ are in the initial stage, and 3\% closed. Currently, EPFCT webpage markets those twenty-eight consolidated programs, none in Santa Elena province. In the next section, I particularly focus on community tourism developed in Santa Elena after the coastal management introduced by CRMP, a national program for managing coastal resources in the $90 \mathrm{~s}$ discussed in Chapter 5.

\section{Community tourism in Santa Elena}

Santa Elena municipality was one of those 60 cantons embarked in tourism decentralization in the year 2001. However, by those years, several communities in the northern parish of Manglaralto were familiar with tourism development. As the previous chapter details (Chapter 5), a national coastal resource management program, known as CRMP, engaged coastal villages under an integrated scope to manage coastal resources during the 90s. Among other actions, CRMP categorized and developed some tourist beaches in Santa Elena to counter the vast devastation of mangroves. 
The most popular project in Santa Elena was the Proyecto de Ecoturismo Comunitario (PRODECOS) or Community Ecotourism Project. The coastal resource management program endorsed this program, which, later on, became a member of Indigenous federation of tourism. PRODECOS' goal was to contribute to poverty alleviation by improving local capabilities and economic sustainability. PRODECOS also promoted individual entrepreneurship but required a commitment "to improve knowledge and reproduce it to others" (Zambrano 2011, 184).

The community-based ecotourism project was a project operated by Centro de Promoción Rural or Rural Promotion Center (RPC), a local NGO. Since 1997, RPC partnered Ayuda en Acción or Help in Action, a Spanish NGO, to intervene the Manglaralto and Colonche parishes, both devastated by 1997-1998 ENSO event (Chapter 4). According to Ordoñez y Marco (2005), PRODECOS sponsored and financially assisted 300 families in 19 communities in north Santa Elena. Later, a report issued in the year 2014 informs PRODECOS developed and co-financed twenty-five restaurants, ten beach tents/seat rentals, seventeen hospederías comunitarias in Manglaralto and Colonche, the parishes CPR intervened (CPR-AeA, 2014).

In an interview with the author (July 2, 2018), Carlos Floreano, a comunero owner of successful accommodation entrepreneurship in LB and PRODECOS beneficiary, states:

"Families who engaged the [PRODECOS] project produced handicrafts made out of natural resources (sea, beach, and wood), provided local gastronomy, tourist guidance in ecological trials, and hospedaje comunitario." 
Hospedaje comunitario or in-family-house accommodation promoted by PRODECOS and CRMP spread throughout the rural comunas of Santa Elena in the early 2000s. The comuneros redesigned some sections of their homes to provide tourists with accommodation while Hospedaje Comunitario became a way to improve families' cash economy. According to David Zambrano, CRP Director (interview with author August $12,2018)$, this rural modality of tourism furthers the usual understanding of tourist accommodation because the provision of a room within a family house enables interacting and holding talks with the members of the family while the tourist engages with the local culture. PRODECOS not only provided funds but this project also "achieved to create an organizational and self-management capacity among comuneros" and an "endogenous effect of appropriation and replication, stimulating an autonomous diversification of multi-sectoral entrepreneurship" (Zambrano 2011, 182). Thus, PRODECOS' project and the Hospederias Comunitarias in Santa Elena reveal a neoliberal rationale centered on the promotion of self-capabilities pursuing the economic security of individuals (Reid 2013, 2018).

In the year 2007, the territory of the peninsula of Santa Elena became an independent province under the anti-neoliberal administration of Ecuador. The leftist government intensively intervened the new province through programs, such as the Plan 5-5-5 and legal frameworks such as the CT, both explained in the previous section. Concurrently, the subsidiarity principle was getting into effect in the cantons of Santa Elena. For instance, in 2010, the municipality of Santa Elena created the Empresa Publica Municipal de Turismo, a municipal corporation to manage tourism in the canton. This municipal office works in compliance with national MT policies and programs. 
However, as León (2013) argues, Santa Elena's tourism reveals a historical disorder between tourism development and second home (or vacation home) development. This controversy in the municipal tourism management worsens when tourism gets into the common-property regime, which explicitly has autonomy over the land and resources. The next section addresses negotiations and decision-making within the complexity of beach tourism development, while the national government maintains its concern about the security and protection of its inhabitants.

\section{Tourism, beaches, and local threats in the seaside village of Libertador Bolívar}

A beautiful view of the Pacific Ocean, mixed with cliffs and hills, welcomes visitors entering from the south of the comuna of Libertador Bolívar. It is a rural community in the north of Santa Elena, parallel to the seashore. The route E-15, part of the binational tourist route called Spondylus Route, crosses a portion of the village. Along the E-15, the comuneros of LB have built homes and small businesses, in roughly 0.62 miles of beachfront. At the end of this area, the Route E-15 turns right and continues toward northern communities. While the road crosses the town south to north, the Atravezado River crosses the town east to west dividing the commercial and residential areas.

Tourism in LB has become crucial for comuneros' wellbeing and has also transformed their life in almost two decades. Table 4 compares LB tourist services in the years 2002 and 2018. Thus, in sixteen years, restaurants increased from 6 to 20 . 
Similarly, from 3 hostels (54 beds ${ }^{7}$ ) operating in the year 2002, by the year 2018, LB had 17 hostels (205 beds). Additionally, thirteen cabañeros now offer tourist services in the north beach, a group of women rents tents and chairs at the beach, other groups of women sell roasted ripe plantain, a couple of families produce and sell traditionally baked corn tortillas, and fifteen artisan shops sell locally elaborated handcrafts.

In addition to the privately-owned providers, the community manages a hostel, called Hospedería Comunitaria, rent a ballroom, lease contract with the paragliding tour operator, which includes an office in the village and a field on the hill. During high tourist seasons, the comuneros organize lifeguard provision and events for tourist entertainment. This economic revitalization also includes fishers, divers (to catch octopus and bivalves), and farmers, who are also part of the local tourist economy supply-chain.

\begin{tabular}{|l|c|c|}
\hline Tourism services & Year 2002 & Year 2018 \\
\hline Restaurants & 6 & 20 \\
\hline Hostels & 3 & 17 \\
\hline Beds & 54 & 205 \\
\hline
\end{tabular}

Table 4. Tourism services in Libertador Bolívar. Elaborated by the author. Source: Isabel Cando Coastman NGO President

Thus, tourism activities in LB integrate and benefit the economy of the whole community. The comuneros are genuinely aware of this new economy in LB. For instance,

\footnotetext{
${ }^{7}$ Beds are accommodation statistics in the tourism industry.
} 
Smeling Suarez, comunero leader, in an interview with the author (August 10, 2018) asserts:

"We cannot separate our economy. We cannot? operate our economy by sectors. They are all correlated."

Similar statements appear in the Community Logbooks. For instance, in a lively discussion held on August 29 ${ }^{\text {th }}, 2014$, the minute records:

"When we discuss on tourism, it is not a single sector. It is about the whole community."

The same log of minutes also reveals the meaning of tourism industry among the comuneros of LB:

"Making Tourism is development for all."

Thus, in Libertador Bolívar, the tourism industry secures local economy and communal wellbeing. The main resource for tourism in LB is the 2.07 miles $(3,325 \mathrm{~m}$.) long beach strip - from the south (Playa Bruja) to the river mouth in the north. The beach is divided into two sections: the north and the south beach. LB's tourist development started in south beach, where six comuneros built the first tourist cabañas by the late $90 \mathrm{~s}$ and early 2000s. Nowadays, the south area is full of rural houses, small artisan/handcraft shops, groceries, hostels, and restaurants. Most of the hostels and restaurants occupy the outer slope of the cliff, facing the sea. Visitors enjoy going down to the beach, where the shoreline contrasts with the warm colors of the sand. On the beach, other comuneros have built thatched sun umbrellas, which they rent to the visitors. Another group of comuneros has built larger thatched kiosks, known as cabañas, where they offer beverages and traditional seafood snacks. 
On the north, the beach has witnessed accelerated tourism development after the year 2009. By the year 2013, the comuneros built a dirt road to welcome tourists (detailed in next section). However, the dirt road occupied the upper part of the beach berm, the ultimate natural defense of the coast. Three years later, the community assembly authorized building tourist cabañas in the northern beach. In 2017, the local government built a seawall in this area, beautified with a promenade, a paved street, an open stage, and thirteen cabanas, which are currently providing a variety of tourist services.

Thus, since the late 90s, tourism development in rural communities of Santa Elena has introduced numerous processes into the comuneros' everyday lives. In particular, these processes include decision-making on the use of the beach within both commonproperty management and gaps within rural legislation. The next section analyses processes of self-organization, decision-making, and mediations over the use of the beach, a common-property resource in Libertador Bolívar.

Tourist beach management in a common-property territory

A tourism-led economy in the rural coast of Ecuador introduced new discussions about beach use into a communal-land property system. Traditionally, the Cabildo approves land possession certificates to build comuneros' homes. Several comuneros, owners of handcraft shops subdivided their homes into workshops, where they sell a variety of hand-made products. However, it has worked differently in tourism businesses. By the late 1990s, the Cabañeros del Sur built their thatched tourist kiosks on inhabited areas at the southern cliff. By the year 2003, they claimed for possession titles. The 
community assembly approved and issued land possession certificates to the cabaneros after several debates. Later on, new cabañas expanded down to the beach.

The expansion of tourist cabanas to the beach brought disagreements among the comuneros, particularly on the appropriate use and possession of beaches. For instance, logbooks of community minutes record:

"The beaches belong to the community" (February 27th, 2004)

"Respect the beach area. You cannot grab those lands" (March 8, 2008)

"No one can conceive they own the beach, but the beach can be rented" (December 27, 2009)

A particular condition the comuna stipulates for private providers is to be registered in the national ministry that regulates common property territories. In this way, the community does not allow foreigners investors in their territory. Only local families can own and manage businesses in LB. The only non-community member is the paragliding operator, who does not participate in the communal management or live in the community.

Businesses owned only by locals differentiate LB from other communities in Santa Elena, where foreign-owned business and second homes development have displaced comuneros from the best sites. For instance, Cedeño (2017) traces changes on the land property in Montañita, a surfing hotspot five miles north from LB. Cedeño reveals that $10 \%$ of Montañita lands now belong to foreigner-business, a process that started in the 80s. Similarly, in the communities of Olón, San José, and Punta Blanca, where wealthy Ecuadorians have built luxury second homes. Furthermore, comuneros of LB constantly remember local episodes defending their territory. For instance, during the 
eighties, shrimp farming grabbed vast extensions of estuaries in communal lands (Latorre et al. 2015). However, in the comuna Libertador Bolívar, it was different. In 1982, LB comuneros confronted land grabbers in an episode they remember as The War. Sadly, they remember a comunero leader died during the armed confrontation. Since then, the comuneros recall this episode when land issues reach the village. Indeed, this memory was important during the recent land struggle. Since 2014, a foreign investor deceitfully grabbed some lands in LB. The investor promised second home developments would bring paid work opportunities into the community. However, after three years, the supposed real estate development never started. During 2017, the community leaders were incarcerated after leading a riot to recover those lands. Finally, leaders demonstrated in court the foreign investor issued fake documentation. After that, LB comuneros legally recovered the plot of land. Thus, land claims have become a pivotal principle guiding comuneros' processes of self-organization and decision-making to keep and manage their common-property territory.

The beach is part of the common-property territory in LB. Accordingly, the comuneros decide the appropriate administration of this resource. Thus, in the year 2009, the comuneros decided to embark into a new tourism initiative. They aimed to expand tourism services to the north beach, next to the river mouth. The goal was to transform the pristine beach into a tourist beach. This area in the north was the backyard of the community, where pigs looked for food from the garbage. Thus, the comuneros executed several communal initiatives to improve the area. First, they forged a campaign to remove pigs from the beach. Then, they cleaned up the garbage and removed the brush in the north beach sector in collaboration with municipal staff (community meeting September 
11, 2009). However, in April 2012, the Risk Management Secretary (RMS) together with the Ministry of Environment, both national government offices, notified the comuna about the prohibition against carrying out projects next to the shoreline. Despite this warning, the comuneros in unison declared to continue improving the north beach.

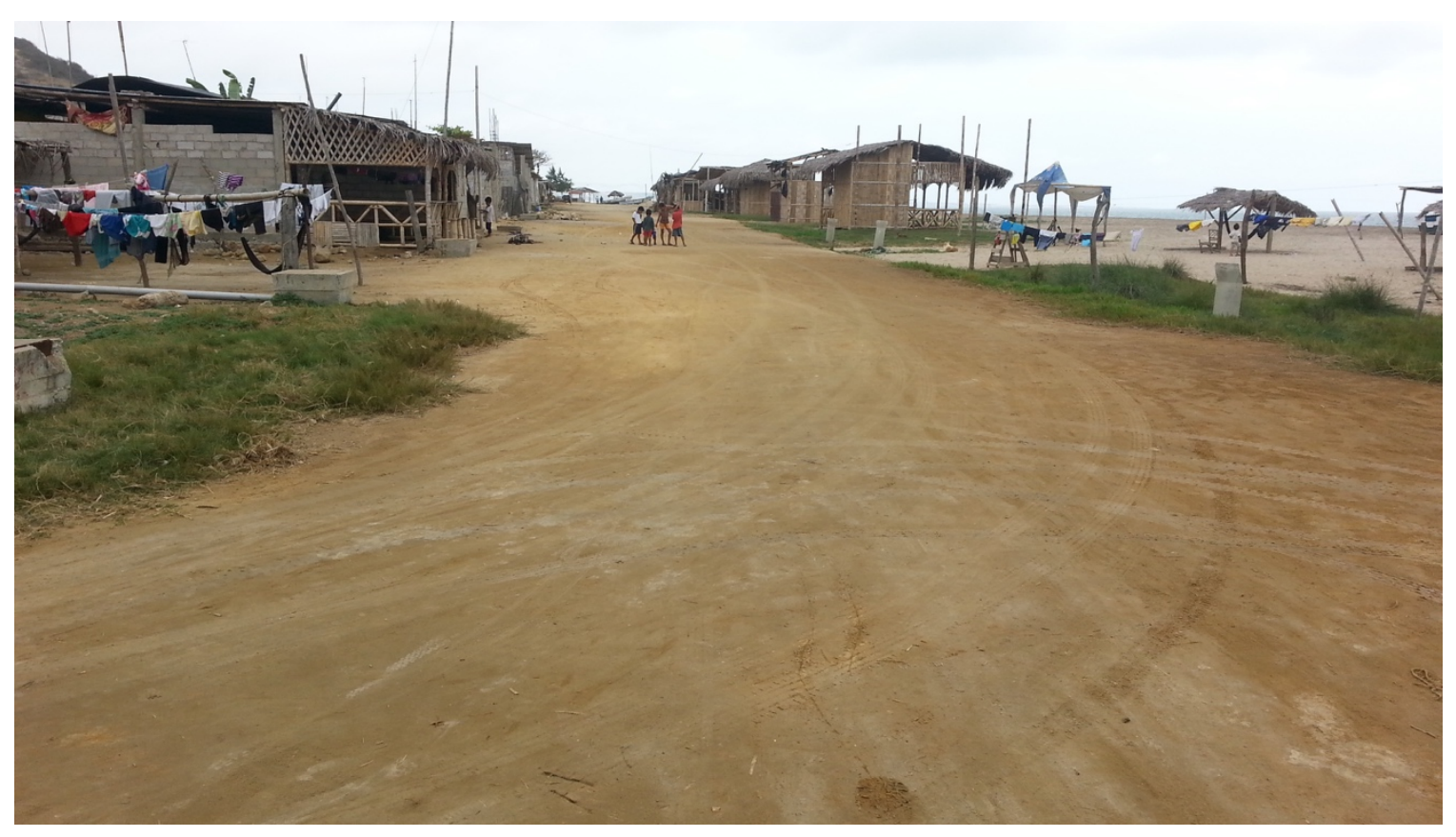

Figure 12. Dirt road in the north beach in November 2016. Source: author (2016 Fieldwork)

Thus, the comuna requested the municipality to construct a road next to the north beach. The municipality supported the construction but clarified that "the road that will be built will not run onto the sand; the road will go through the land" (Community Meeting August 31,2012). On early 2013, the comuneros inaugurated a dirt road in the beachfront (Figure 12). In November 2013, the Community Assembly approved ten cabañas in this area, despite municipal warnings on beach banned constructions. 
According to Community Assembly minutes, cabañas owners must pay fees, keep an area for a sand volleyball and soccer fields, and cooperate with annual festivities.

However, the then-president imposed a clause: "If they do not comply, those plots will be returned to the community" (Community Assembly minute, November 28, 2013). It was a communal ownership reminder.

Negotiations with the municipality continued during early 2014 to transform the dirt road into a Malecón, or promenade. Malecón's municipal design shows a cobbled sidewalk, landscaping, and an open stage. The design did not include tourist cabañas because municipal ordinances ban constructions on the beach. The municipality of Santa Elena demanded an organized re-construction of the cabañas after constructing the malecón. According to municipality design, cabañas will not continue on the beach; kiosks would be built on the promenade. In doing that, the municipal staff aimed to support comuneros to legalize their tourist cabañas since they would comply with RMS norms.

Conversely, it was not the best option according to LB tourist business owners. For instance, Oswaldo Chancay, tourist cabaña owner, (interview with author June 6, 2018), asserts:

"Tourists like to be served here on the beach"

Similarly, Milton Cordova, tourist cabaña owner (interview with author June 21, 2018), argues:

"Tourists come to spend their time enjoying the sand and the sea, while we kindly deliver them the meals or drinks they request" 
In sum, LB has developed a proper form of community tourism, one that admits privately owned and operated small-scale tourism businesses. Furthermore, the beach is now the main resource to secure the community's tourism-led economy. In recent years, the comuneros intervened the pristine north beach to create more tourist spaces, consequently, more community benefits. However, the intervention of the beach and the tourist operation in LB do not fulfill Ecuadorian tourism and risk management regulations. The next section reveals how comuneros co-exist with legal entanglements that, ultimately, increase community economic vulnerability.

\section{Entanglements between tourism development and risk management policies}

At LB, tourism development and risk management interplay without reaching coastal rural realities. First, most cabañas in LB, and Santa Elena canton as well, are located in what the Risk Management Secretariat has declared "risky zones," unsafe zones where construction is banned. Second, a national regulation disassociated with the rural reality persists despite governmental efforts to decentralize national development policies. In this section, I trace both legal mismatches, which locate the comuneros tourism-led economy in spaces of illegality they endure every day, since community tourism secures comuneros wellbeing despite those legal entanglements.

The comuneros are conscious they have developed their small-scale tourist businesses in risky zones since national offices have informed them of this in advance. For instance, in 2004, the Harbor Captaincy and the Municipality of Santa Elena informed them that anybody making business on the beach would be able to get an operation permit (Community Assembly minute, December 8, 2004). Community 
Assembly minutes reveal the comuneros continued having the same reply during the next three years.

This issue, seen in many seaside comunas at Santa Elena, became a concern highlighted on official documents when the leftist government took the national administration and requested to plan local development. For instance, an analysis of territorial issues in Manglaralto Parish conducted in the year 2011 states:

"Some businesses that offer tourist services do not meet certain specifications required by law and regulation, as in the case of some food and beverage businesses that because of their infrastructure, services or size could not be categorized or also the community hostels that do not have the minimum number of six rooms, could not be classified as hotel. Therefore, they are outside the cadaster of tourist services, distorting the real existing tourist offerings" (GAD-M $2011,85)$

The next Manglaralto Development Plan issued three years later, repeats those two main issues on tourist regulations at Santa Elena (GAD-M 2014). Thus, the antineoliberal state practices did not manage to appropriate rule tourist operation in the rural coast. By the year 2018, the Ministry of Tourism had certified only one of the seventeen hostels operating in LB, while the restaurants and thatched cabañas on the beach do not achieve any certification.

Importantly, other communities in Santa Elena replicate the same feature. For instance, according to municipal records, the community of San Pablo has seventy-two 
cabañas operating in risky areas. The community of Ayangue has seventy-four cabañas in less than seven hundred linear meters (0.43 miles). The community Olón has fifty-six, other communities have an average of twenty cabañas, and other communities, such as San Antonio and Valdivia, started building new cabañas in the year 2018. However, all cabañeros in Santa Elena operate with a permit issued by the National Police, which does not mean a tourism certification.

In addition, the National Public Health Regulation, Control and Vigilance Agency (PHRA) issue a permit that warrants public health regulations to restaurants. At LB, only the cabañeros del Sur (restaurants) got this permit in the year 2018. However, most of the restaurants do not have PHRA permit because they do not have a Registro Unico de Contribuyentes or Income Taxpayer Identification Number. According to the law, an taxpayer identification is mandatory for all individuals or companies performing occasional or permanent economic activities in the country. However, given the structural weakness of the Ecuadorian Internal Revenue Service, rural areas are far from its control. Nevertheless, neither the police permit nor PHRA's, guarantee MT's registration and certification.

Additionally, many hostels in rural coastal villages, vital for comuneros livelihoods - do not match with the national normative on accommodation services. Since 2002, MT issues the Licencia Unica de Funcionamiento, a license to operate a tourist service: mainly accommodation, food and beverages (restaurants, bars, cafes, kiosks, and so on), and community tourism. From 2015, tourism regulations admit a minimum of five rooms in the hosterias -accommodations adapted in houses, and lodges, or accommodations built with local materials and vernacular architecture. Additionally, 
the regulation included Casa de Huéspedes or Guest Houses, lodging offered at homes, with at least two and up to four exclusive rooms for guests. MT regulations also require taxpayer identification number, assets inventory, and paid property taxes. MT's certificate requires compliance with the RMS regulation, which bans infrastructure on beach berms or river mouths (SNGR-005-2011) (See chapter 4). However, MT regulation does not include tourism specifically developed in collective-property territories.

The municipality of Santa Elena created a tourist cadaster aiming for better management of local tourism, informed Mario Aquino, Director of Santa Elena Municipal Tourism office (interview date July 7, 2918). In 2018, the municipal cadaster registered three hotels, seven restaurants, and a tour operator in LB, in addition to the 13 cabañas at the malecón. Other businesses in LB operate without complying any regulation. The municipal tourism management department cannot issue any license if MT does not categorize tourist businesses. In December 2018, the Ministry of Interior updated the scope of the police permit to tourist businesses not regulated by the Law of Tourism (E.D. \#623-2018). However, at the municipal level, the Tourism Office Director, and Richard Flores, RM Director (interviews with author July 31, 2018), confirmed, the municipality of Santa Elena would not be able to certify businesses built on unsafe areas. However, despite regulations' incongruences, an endogenous tourismled economy has continued being the pivot in Santa Elena's common-property territories. The next section analyses the effects of this particular tourism industry on the beach ecosystem. 
Natural and human-made changes at the beach

While the beach is vital in the LB tourism-based economy, increasingly the villagers are confronting the effects of coastal erosion. Coastal erosion is a process of long-term removal of sediment and rocks producing shoreline retreat. Natural causes and human activities can erode the coast. Natural driving forces are storm waves, flooding, tides, currents, winds, sea-level rise, geological process, and climatic effects. Figures 13 and 14 show erosion and damages in LB beaches after the November 2015 swell and September 18, 2018 tides.

Waves are dominant natural forces producing physical changes in the shoreline. Wind interaction with the surface of the ocean produces waves, which roll on until they crash on the beach. Near the coast, local wind produces the sea's waves. In the Pacific Ocean, winds and storms produce a series of traveling waves from the offshore, called swells. They have higher energy and wavelength than waves produced by local winds. The direction of swells approaching the coast plays a critical role in the accumulation of sediments at the beach. According to the Ecuadorian Coastal and Marine Area Regulation Plan (SENPLADES 2017), from December through March, waves arrive in Ecuadorian coasts from the north and northwest, while the southwest waves dominate during April to October. Oceanographers use forecast techniques and regularly measure wavelength, direction, and height to estimate waves' effects on the beach. Storm waves (waves produced by storms) are another phenomenon affecting the beach. Storm waves originate in the southern and northern hemisphere before reaching the Ecuadorian coast. Even though maximum wave breaking heights are less than 2.5 meters ( 8.2 feet), storm waves 
have more extended periods (between 16 and 18 seconds), reaching the upper part of the beach and eroding the berm, a natural storage of sand which delays natural beach erosion.

Tides also impact waves incursion onto the beach. Tides or the gradual rise and fall of the sea level result from the gravitational forces among the moon and the sun, and the rotation of the planet. A complete cycle of tide goes between the highest and the lowest sea levels. In Ecuador, a complete cycle lasts approximately twelve hours (semidiurnal) and the time between consecutive high tide and low tide lasts 6 hours. Thus, Ecuadorian beaches receive two highest sea levels and two lowest levels every day (every 24.5 hours). When the moon locates at the right angle to the sun, the values of the tidal generating force decrease, producing lower than normal tides. Conversely, during the full and new moon, the moon and the sun line up (a configuration called syzygy), producing higher than normal tides or spring tides, commonly known in Ecuador as aguajes. Sanchez (2015) records, tidal ranges up to 2.5 meters ( 8.2 feet) between high and low tides influencing wave running onto the beach in LB.

Additionally, Ecuador is located within the Inter-Tropical Convergence Zone, an area converging northern and southern trade winds near the equator line, consequently affecting waves' behavior. During average years, in the coast of Ecuador (and Peru) the strong trade winds blow the warm surface waters, producing an abundant supply of food for small fish, making a good living for fishers. However, during El Niño-Southern Oscillation (ENSO) phenomenon, trade winds fade for some months. Later, trade winds start to push the warm surface water back again, going back to normality. 


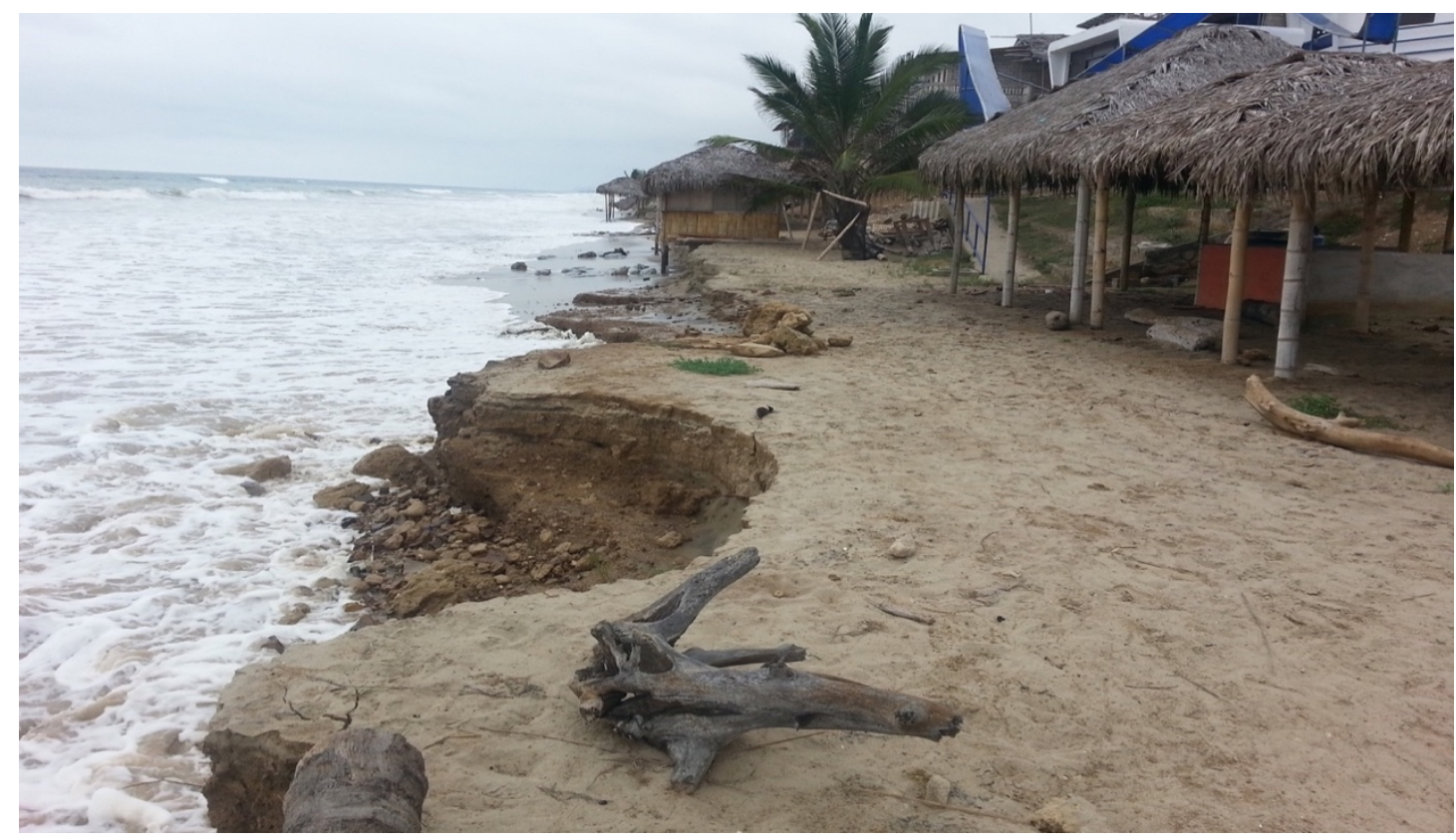

Figure 13. Damages at Libertador Bolívar south beach during November 2015. Source: Enrique Sanchez

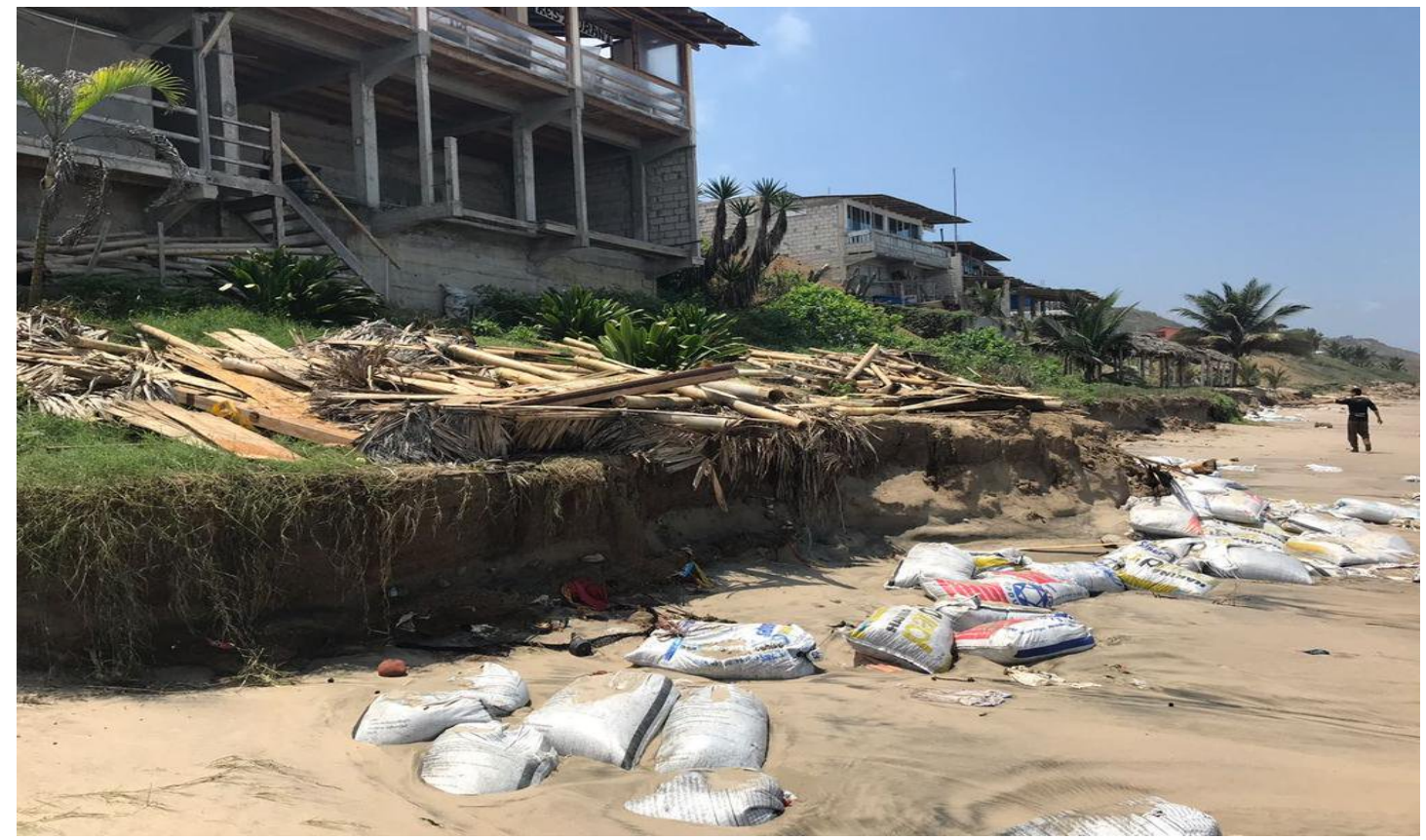

Figure 14. Damages at Libertador Bolívar south beach during September 2018. Source: El Universo (2018) 
Associated with sea temperature, ENSO also produces other effects on the shoreline. First, ENSO's effect increases sea level. According to a 1998 report (CAF 1998), the $1997 / 1998$ ENSO phenomena increased sea level by 1.38 feet $(0.42 \mathrm{~m})$. Second, ENSO also produces storms with significant effects on the coast. In Ecuador, the median precipitation in this region is $206.4 \mathrm{~mm} /$ year - traced from 1982 - 2011 (Garcia et al., 2017). In the northern part of Santa Elena Province during El Niño event 1982-83 precipitation increased up to 3,000 mm. During 1997-98 El Niño event, the CENAIMESPOL gage station in nearby Libertador Bolívar recorded precipitation up to $3,500 \mathrm{~mm}$ (Sánchez, 2015). The extreme raining and sea-level rise, ENSO brings to the coast, flood areas close to the sea and plunge river channels natural drainage.

Global warming aggravates the effects of sea-level rise on beaches. Nicholls \& Cazenave (2010) demonstrate that the mean rate of sea level from 1993 to 2009 rose amounts to $3.3+/-0.4 \mathrm{~mm} /$ year. Rising sea levels "act as an enabler of erosion because higher water levels allow waves to act further up the beach profile and move sediment seaward" (Zhang et al. 2004, 55). Sea surface temperature is also a major driver of accelerated sea-level rise (Laffoley \& Baxter 2016). Laffoley \& Baxter demonstrate exceptional global sea surface temperatures in the years 2014, 2015 and 2016. Sea surface temperature would "double in frequency" and "intensify" El Niño events (Laffoley \& Baxter 2016, 36). Thus, adding another threat to the beach ecosystem. Concerns on coastal erosion appear in official Ecuadorian documents. For instance, the Coastal Marine Area Regulation Plan issued in 2017, states:

"In recent years, the influence of waves, increasing erosive processes in several sites on the coasts, has been notorious; many of them associated with the arrival 
of swells produced by tropical storms at high latitudes, exacerbated by anomalous events such as El Niño" (SENPLADES 2017, 44).

At the provincial level, coastal erosion's concern also flourishes in official documents. For instance, the 2015 Santa Elena Province Development Plan admits: "A new consideration in the analysis of the vulnerability of human settlements relates with the average elevation of the sea, it was registered with the presence of El Niño phenomena, but has become more reiterative by the swells. The increase of sea level causes coastal erosion and damages in the shoreline, especially, the tourist infrastructure built at the edge of the beach" (GAD-PSE 2015, 10)

Two Manglaralto Parish Development Plans (GAD-PM 2011, 2014) also address the erosive concern on beaches. For instance:

"Spring tides sporadically occurring in Manglaralto has affected the shoreline of the Manglaralto Parish, coastal erosion threats the communities of San Pedro, Libertador Bolívar, San Antonio, Cadeate, Manglaralto, Montañita, Olón, Curia, San José, and las Núñez; they are prone to sea destruction” (GAD-PM 2014, 18) Enrique Sanchez, a coastal engineer who traces the coast of Santa Elena since the 1990s, explains that several beaches in Santa Elena "could not recover the sand and the erosion continues" after ENSO 1982-83 and 1997-98 (interview with author June 18, 2018). According to the diagnosis Sanchez has done (2015), 10\% of Santa Elena's coasts are currently eroded, and another $10 \%$ is vulnerable to erosion. 
Furthermore, argues Sanchez, erosion in Santa Elena increases when high tides concur with spring tides or aguajes; and more damage, when they both also concur with ENSO. However, concerns increased during the year 2015, when waves severely battered the coast of Ecuador. Swells battered Santa Elena beaches on January 5 and 31, March 26, May 2, July 23, August 2, 5 and 9, September 28, and October 9. The events on January and May went along with spring tides while the September's event concurred with the perigee - the closest the moon comes to the Earth. News reported similar conditions occurred in previous years (El Comercio 2009, El Universo 2011)

At the local level, inhabitants of LB have also noticed the coastal retreat. For instance, Carlos Floreano, owner of a hostel in the meeting held on August $31^{\text {st }}$, 2012, states:

"The sea is winning space from us..... When we started our tourism businesses, we had more space [at the beach], now, the sea has beaten us, at least 9 meters" (29.5 feet).

Pedro Suarez, an elder and inspector at Libertador Bolívar, also comments:

"It seems like a lie, that the sea could be where it is, but the sea also grows. If there had not been growing, we would not have lost the two rows of houses. Years ago, the sea was well below." (interview with author August 10, 2018).

Similarly, another elder of Libertador Bolívar states:

"The sea was very far.... We who live here, know that the sea has been rising...The sea has continued rising, growing up. It is rising. We have the force 
of the sea, the aguajes during the full moon" (E15 interview with author July 15, 2018).

Sanchez (2015) also analyzes contemporary erosive processes at Libertador Bolívar beaches. At the river mouth, sedimentary processes have developed low areas, which produce a berm, the natural storage of sand. This berm delays natural erosion in the north beach explains Sanchez. On the contrary, on the south beach, the cliff naturally restricts the development of the berm and minimizes the sand reserve. Sanchez found evidence of erosion in the southern part of the beach next to the cliff in addition to low berm levels, exceeded by storm waves' impacts and during El Niño occurrence, as well.

Additionally, human activities can also be responsible for wearing away beaches and bluffs along coastlines. Particularly in LB, tourism-led development has exacerbated beach changes. At the south beach, locals built the original cabañas in the unstable slope of the southern cliff. In order to protect their tourist businesses, the comuneros have inadequately filled the cliff, with deficient material and without technical procedures.

Indeed, the comuneros are aware of the threat they coexist with. For instance, the Community Assembly Minute January 17, 2004, records:

"The [southern] cabanas are located on unstable land."

Similarly, comunero owners of restaurants in the south cliff assert: "I struggle with the mud coming from the hill during severe rains" (E9 interview with author July 8, 2018)

"When I was a child, we saw the mudslide going down from the cliff toward the beach. However, my uncle cemented it to protect the land. Now it is safe" (E8 interview with author July 7, 2018). 
"During the night, trucks brought gravel and stone to fill this area, until the dune disappeared" (E18 interview with author June 30, 2018).

Despite comuneros' acknowledgment of unstable areas, they remain at the bottom of the cliff, where tourists enjoy the sun, the sand, the beach, and cocktails and seafood.

The north beach of Libertador Bolívar has also suffered human intervention. Google Earth images comparing the years 2006 and 2016 reveal the transformation of the beach. The 2006 image (Figure 15) shows seagrass naturally growing between the beach and houses built along the beachfront. According to the comuneros in LB, the construction of a road in the north beach benefits their tourism-led economy:

"No, there was not that street. We built it to receive more tourists. They can park their cars and go to the beach" (E7 interview with author November 15, 2016).

"Now we have this area for tourist parking. It will increase visitors to our beach" (Milton, Comunero owner of a cabana interview with author June 21, 2018)

The 2016 Google Earth image (Figure 16) shows that a dirt road replaced the natural seagrass and several cabañas built on the beach. In 2017, the local government constructed a seawall to protect the north beach. The dirt road became a beautified promenade built on the top of the seawall, where comuneros re-built their thatched cabañas and tourists spend their leisure time.

All those anthropic interventions in the north beach of LB have changed the very nature of the beach ecosystem. Sanchez (interview with author June 18, 2018) estimates, beaches in LB have retreated roughly ten meters (32.8 feet) between the years 2006- 
2015. This condition, and the fact that the seawall does not wholly stop coastal erosion's effects, implies imperceptible processes that modify the beach, concludes Sanchez.

In sum, the beach ecosystem in Libertador Bolívar, is constantly prone to natural processes of sediment removal, which, eventually, erode or retreat the beach. Even though erosive processes are continuous and dynamic, other stressors are increasing changes of the beach. On the one hand, a tourism-led economy that requires beaches as a natural resource to develop the industry. On the other hand, global threats emerging from atmospheric and oceanographic phenomena are increasingly frequent disturbing the beach ecosystem and increasing the threats, including the possibility of El Niño events. The next section addresses to Comuneros decision-making and mediations to confront increasing threats at the beach.

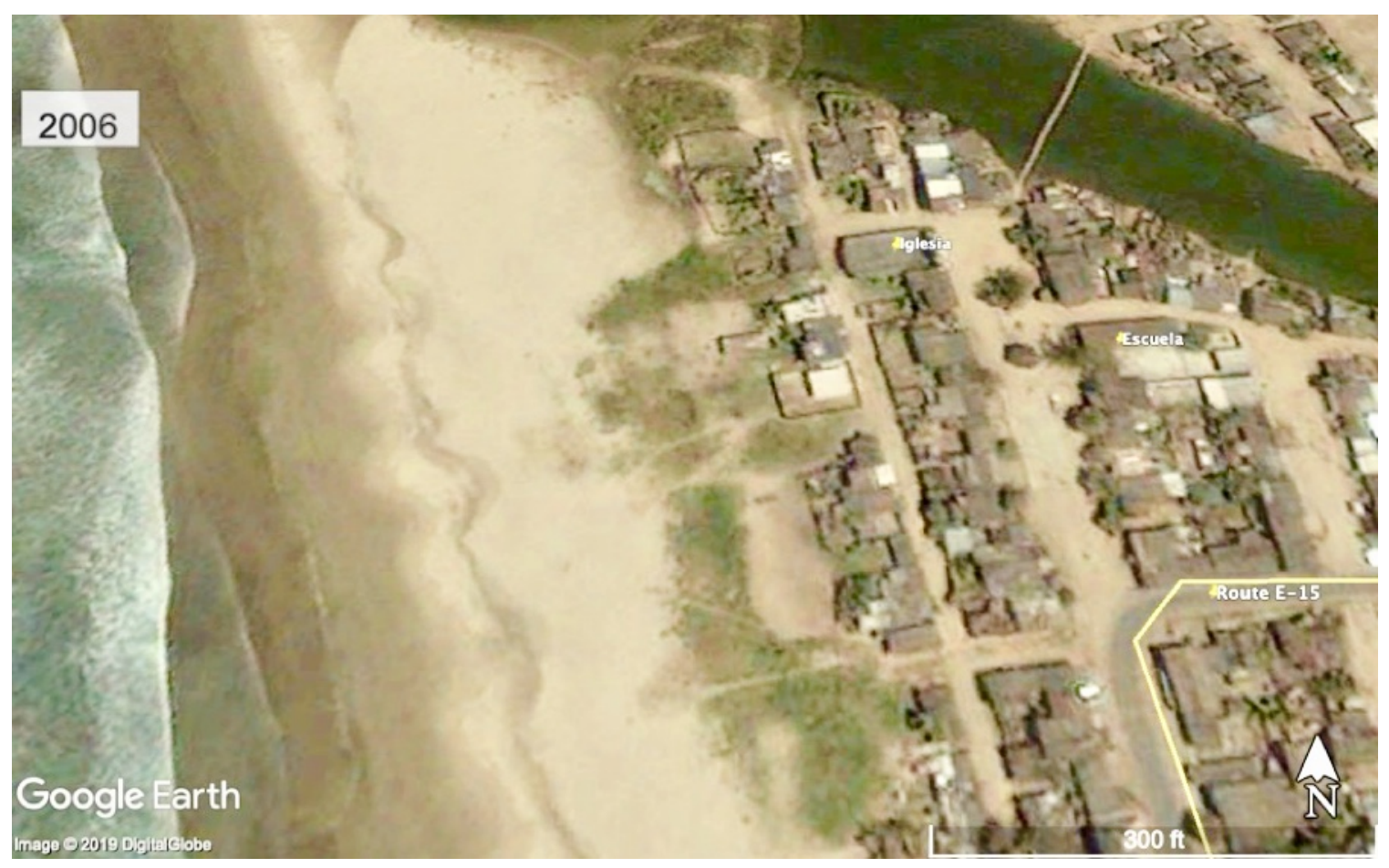

Figure 15. Libertador Bolívar north beach in 2006. Source: Google Earth. 


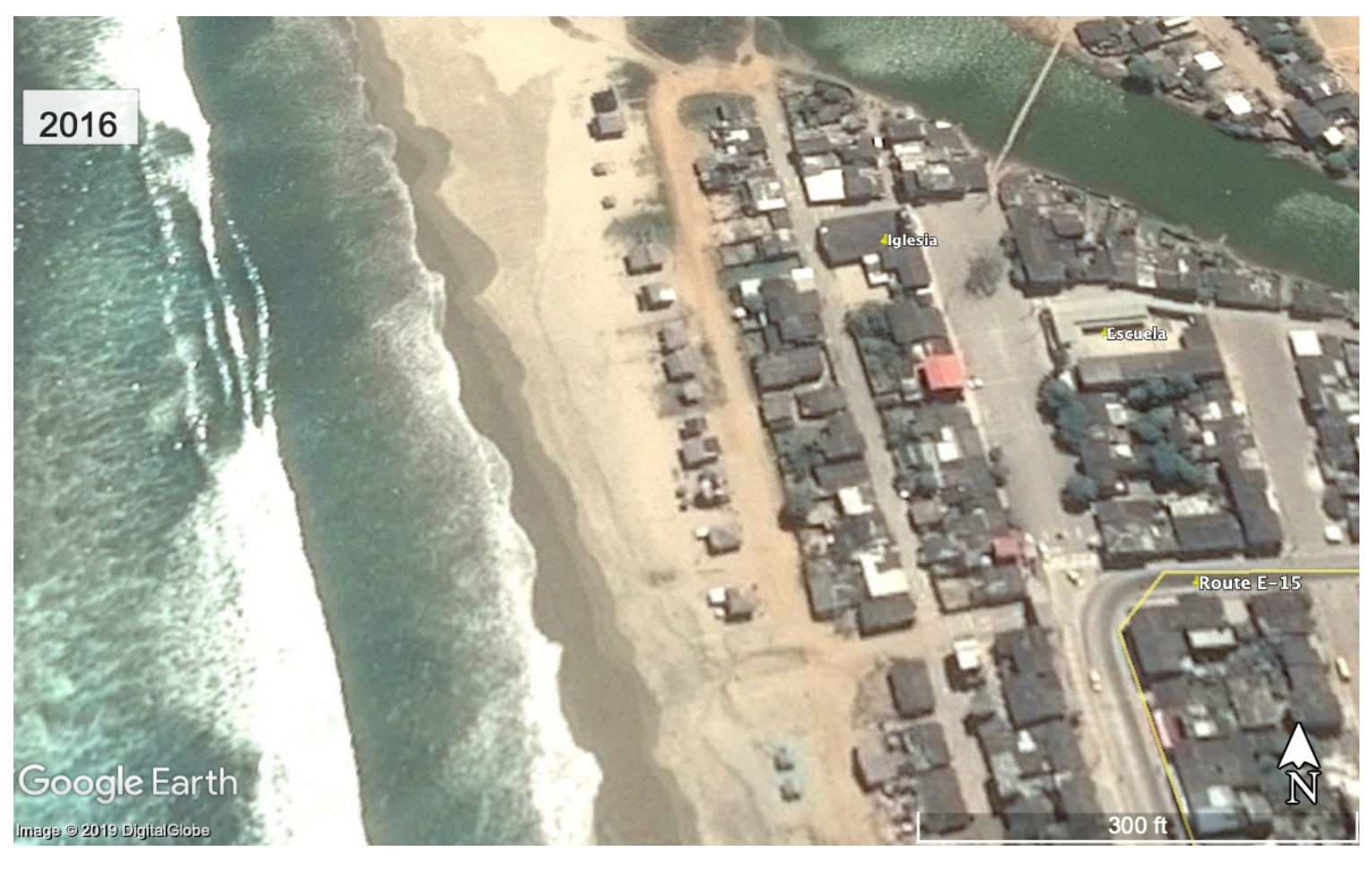

Figure 16. Anthropic effects at Libertador Bolívar north beach in 2016. Source: Google Earth

The increasingly frequent local threats

Since LB tourism-led economy depends on the beach, any disturbance at the beach affects the whole community. As I show in chapter 4, Santa Elena is prone to seasons of extreme rainfall and droughts, effects of ENSO phenomena. Tsunamis are also a threat, according to RMS. However, the sea is more frequently battering the beaches of Santa Elena, particularly affecting the local tourism-led economy. Swells destroyed cabanas and houses at Santa Elena during 2009, 2010, and with more frequency and intensity during the year 2015 (Sanchez 2015). The swell of May 2, 2015, that concurred with the syzygy (when the moon and the sun line up producing higher than normal tides), impacted the inhabited area at the north beach of LB. Figure 17 shows a picture captured 
by a comunero during the onslaught of waves, when seawater ran onto the houses' backyards, covered the dirt road, destroyed several cabañas, and reached sewer system pipes. Consequently, this event increased LB population's risk.

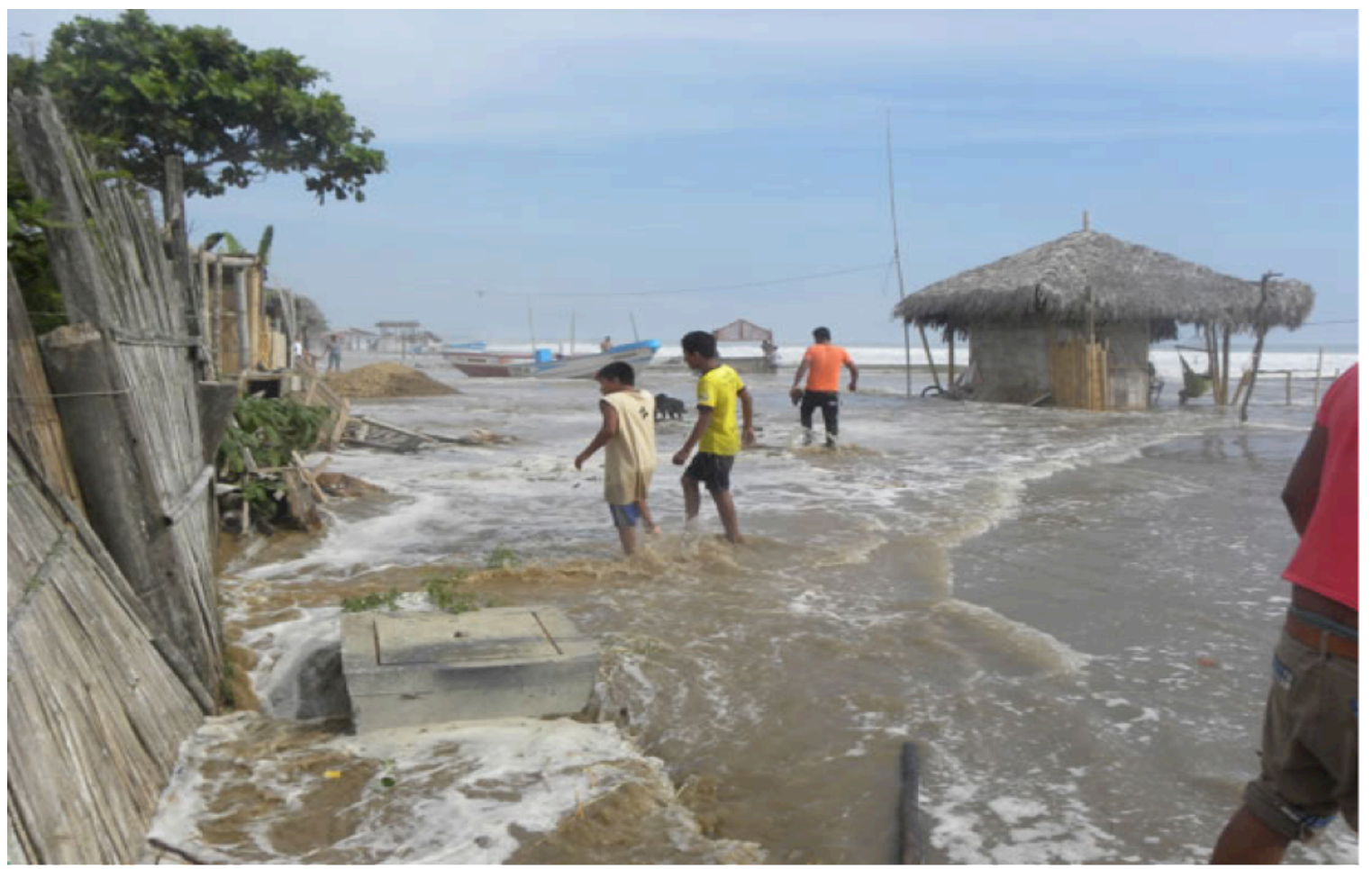

Figure 17. Waves battering the dirt road on May 2, 2015. Source: Enrique Sanchez

Immediately after, comuneros convened a special Community Assembly, where they decided to request governmental protection. In response, RM municipal staff built a temporary protection made out of rocks and activated an Emergency Operation Committee (Chapter 4). This action would allow the municipality to have accurate information about the emergency, and then take effective mitigation interventions. In result, the need for permanent protection to the whole LB beach emerged, states RM Director (Richard Flores, interview with author July 31, 2018). Furthermore, the 
technical study issued after the emergency recommended prioritizing seawall construction rather than the malecón. In addition, by the time this local emergency occurred, the RMS 50/50 program had concluded. Consequently, the municipality would need to finance the whole construction: the seawall and the previously promised promenade. Accordingly, the municipality prioritized the population's protection rather than the safeguarding of the local tourism-led economy. This fact brought disagreements between the municipality and the LB comuneros.

On August 2, 5 and 9, and September 28, 2015, waves severely battered the village again. Since the last event surged the tidal pond, the Prefecture had built retaining walls in the river mouth (see Figure 10). However, the beaches are under municipal management and control. Thus, comuneros made another claim to the municipality for protecting the beaches of Libertador Bolívar. The mayor needed to decide between a seawall protecting the whole beach strip but without Malecón, or to build a seawall and the promenade in the north beach. The Municipal decision was to protect the north beach, where the inhabitants are at higher risk since infrastructure at the south beach does not include houses, only tourist businesses.

However, this proposal brought another disagreement between the municipal government and the comuneros: the seawall's technical height compliance. Seawalls are 6 or 7 meters (19.7 to 23 feet) deep. On the top, they need to fulfill technical specifications regarding height. The height of a seawall is related to the level a maximum wave can reach in extreme conditions. It depends on local oceanic and topographic conditions. Regulations in European countries require $100 \%$ of protection, that is to say, waves' impacts will never destroy beach infrastructure. In Ecuador, there is no regulation 
on this parameter. LB's seawall was designed with a $2 \%$ risk of being overcome by the height of the sea (Sanchez 2015). That means that there is a possibility that, three days per year, waves can surpass the seawall's height, explains Sanchez (interview with author June 18, 2018). However, the comuneros demanded a seawall with a height lower than the technical specifications. Otherwise, the coastal protection would make a barrier separating the beach from the village; consequently, destroying LB's major tourism attraction.

The beautified Malecón was inaugurated in December, 2017, with much rejoicing among inhabitants. After eight years, their greatest desire had become true. A six-meterdeep seawall underpins the Malecón. This protection has the specific function of resisting the energy of the waves. However, it does not meet the height specified in the technical study. Consequently, the risk waves can rise above the protection wall doubled. This is even more true in extreme conditions, such as ENSO concurring with aguajes and syzygy, as it occurred during the 97/98 event. Furthermore, between the Malecón and the sea, locals built their tourist recreational cabañas again. The municipality is aware of this situation and is driving efforts to reduce such risk through constant monitoring and alerts.

The 2018 tourist season was successful, as visitors enjoyed the new infrastructure that LB offers. However, on September 13th, 2018, swells again battered LB (El Universo 2018). This time the waves destroyed the tourist infrastructure at the south beach. The claiming process started again. The Community Assembly meeting with the Mayor and the Tourist and Risk Management municipal departments activated an Emergency Operation Committee while the Comuneros submitted a claim for protection. While I write this dissertation, discussions on the construction of the seawall at the south 
beach continue. However, like Milton, whose family income depends on a tourist cabana at the malecón, argues:

"We are at risk, but if we do not risk, tourist will never visit this place."

Thus, the comuneros' major concern is the economic security while they are conscious of the risk that the tourist infrastructure is prone to at the beach. Paradoxically, neither the Ecuadorian RMS policies, nor international hegemonic frameworks, include small but quotidian threats, such as the waves increasingly battering the beaches of Santa Elena. Both national and international policies on disaster and risk management focus on efforts to protect the population from catastrophes. However, local events threaten comuneros' economic security and impact the beach ecosystem. The next section discusses what these local, small, and, chronic events entail within the politics of resilience.

\section{Conclusion: local threats, slow emergencies, and the politics of resilience}

More than three decades ago, the comuneros of Libertador Bolívar decided to secure the future of the whole community by embarking in a global industry: tourism. However, since the comunas of Santa Elena exist in rural areas and include commonproperty lands regimes, the comuneros have developed a tourism-led economy within legal entanglements. Consequently, their tourism-led economy is constantly at risk. While the comuneros circumvent those local legal incongruences through processes of self-organization, decision-making, and mediation, other factors also threaten the tourist infrastructure at the beach. The moon converging with the sun, gravitational factors, and other hydro-meteorological stressors affect waves' force and, consequently, their impact 
at the beach. Furthermore, global warming aggravates the effects of waves and sea-level increase, impacting the village of LB. In Santa Elena, waves threaten but are not catastrophic. However, wave disruptions on the beaches are more and more frequent. Consequently, legal entanglements and waves' unpredictable behavior have become local stressors the comuneros endure in a daily basis.

Thus, the comuneros coexist with small, local, and misrepresented events that, in a global scale, "never quite achieve the status of having occurred or taking place" (Povinelli 2016,13). Small but quotidian processes are important since they can also change the very nature of systems over time (Chapter 2). Furthermore, in the interval of catastrophic but sudden disruptions, such as ENSO, the comuneros deal with those slow and chronic events. The contemporary history of the comuneros also reveals processes of self-organization, decision-making, and mediation addressing those "quasi-events" (Povinelli 2016). On the one hand, they decide over their territory management. On the other hand, they mediate governmental intervention and demand constitutional rights of protection.

Since the comuneros made their claim for protection, comuneros' quotidian struggles with waves battering the beach also instantiate what Anderson et al. (2019) call slow emergencies. Anderson et al. (2019) propose the descriptor slow emergencies to understand ordinary circumstances that demand urgent governmental action. Slow emergencies highlight those not punctual, not acute emergencies, which also demand collective political or ethical response. Thus, slow emergencies are constant and imperceptible episodes, locally endured by those who coexist with small but non- or misrecognized threats. 
The concept introduced by Anderson et al. also counters the disaster-led emergency management promoted worldwide. Instead, slow emergencies focus on the effects of ordinary events that demand governmental intervention. Similarly, comuneros struggles between waves and tides break the dominant focus on catastrophic events. First, the municipal government applied mitigation techniques to prevent waves' constant damages on the beach infrastructure rather than responding to RMS programming. Second, since the comuneros are conscious that tourist infrastructure is prone to waves and tidal threats, then local realities at LB reveal alternative approaches to risk. Comuneros coexist with recurring small uncertainties. Paraphrasing Berkes et al. (1995), the comuneros allow small and unpredictable perturbations to enter in the socioecological system instead of locking them out, as a risk and disaster management rationale aims to do.

Furthermore, at the coastal rural communities in Santa Elena, economic security is their main concern. Consequently, comuneros self-organization, decision-making, and mediations revolve around an economized life. In LB, community economic survival is more lifelike than any possibility of catastrophic events the national government addresses, such as ENSO or a tsunami (Chapter 4). Moreover, economic security justifies beach intervention, changing the pristine landscape into a modern promenade while a seawall - a human-made wall that reduces erosion and resists waves energy - protects the population.

Then, resilience is not exclusively an external program imposed through governmental techniques. Instead, focusing on local and chronic disruptions turns the analysis of resilience into internal processes within the interplay of the social, the 
ecological, the economic, and the political. At the local level, resilience entails political processes that include nature, population, and governmental security techniques. First, LB beaches are prone to erosion; a natural chronic process nowadays exacerbated by human interventions and global warming. Second, on a daily basis, the population deals with slow emergencies to secure the village economy. Third, governmental resilience and sustainable development programs in Ecuador failed to reach rural realities appropriately. Thus, the case of Santa Elena, the use (and abuse) of natural resources, individuals living in the interstices of national policies, and governmental logics towards securing the population's wellbeing, configure dynamic and continuous subsets of political processes within the endless and complex human-in-nature relationship.

An uneven political process between nature, population, and security techniques will lead to unnoticeable socio-ecological damages. Thus, the politics of resilience should include not only social demands, as in the case of Libertador Bolívar, but also the claims made by nature. In LB, the beach is suffering the effects of local self-capabilities pursuing the economic security of the community. However, within the socio-ecological relationship, nature demands to be approached as an object of political struggles. In the next section, I reveal how the Ecuadorian government's rationale of securing population problematize interventions. 


\section{CHAPTER VII}

\section{Between development and security: the governmental problematization of nature}

Throughout this dissertation, I have unraveled different stressors interplaying in seaside communities of Santa Elena, Ecuador. In doing so, I disclosed changes in Santa Elena from the $1980 \mathrm{~s}$ - after the decline of the shrimp farming industry - through 2018 , one year after the anti-neoliberal government left the presidential office. The management of coastal resources and tourism development mainly relate to those changes in Santa Elena. While the initial concern regarding deterioration of coastal resources in Santa Elena was the impact of the shrimp farming industry, after three decades, a tourism-based economy is exacerbating the use of sandy beaches. The dynamics of environmental deterioration intertwined with tourism development reveal consistent governmental concerns on securing the wellbeing of Santa Elena's comuneros. On the one hand, the neoliberal recipes adopted in Ecuador during the 1980s and early 2000s aimed to improve coastal conservation by enhancing comuneros' capacity to create a sustainable economy - based on appropriate use of the beaches (Chapter 5). On the other hand, the anti-neoliberal government ruling Ecuador from 2007 through 2017 aimed to reduce comuneros' vulnerability to natural disasters, such as severe floods, ENSO or a tsunami (Chapter 4).

Drawing upon Julian Reid's work on the sustainable development-resilience nexus $(2013,2018)$, this chapter brings together the ongoing nature-development-security problematization on the coast of Santa Elena. According to Reid, the sustainable 
development-resilience nexus reveals the neoliberal appropriation of both sustainable development and resilience. In doing so, Reid aims to decenter the security discourse supporting neoliberal adaptation that allows it to survive despite changes in government. Security has been the rationality underpinning Western development, argues Reid. "Sustainable development deploys ecological reason to argue for the need to secure the life of the biosphere," however, "neoliberalism prescribes economy as the very means of that security" (Reid 2013,354). Thus, sustainable development, advocating ecological reasoning, actually subjugates individuals to live for economic security. However, continues Reid, resilience is now the rationality underpinning sustainable development. On the one hand, resilience appeals to security by inculcating a permanent exposure to threats and risk. On the other hand, in line with neoliberalism, resilience also advocates for decentralized responsibility at the local level (Smith 2015, Joseph 2013, Coaffee \& Fussey 2015).

In this chapter, I trace the shifts between the ecological and developmental issues in Santa Elena to reveal the sustainable development-nexus in Ecuador. In order to elaborate on the case, I turn to the genealogy of resilience traced in the previous chapters, which has shown three decades of changes and interventions in the coastal areas of the Santa Elena peninsula. By tracing the security concern for the lives of comuneros, I observed a constant nature, development and security problematization justifying the continuous deterioration of ecosystems despite neoliberal or anti-neoliberal state practices. 


\section{The ongoing problematization of nature in the coast of Ecuador}

Shrimp farming in Ecuador became one of the most important industries contributing to the country's economy during the last decades of the twentieth century. However, the shrimp industry also brought deterioration of the coastal ecosystem. In the thirty years from 1969-1999, Ecuador lost $26.5 \%$ of its mangroves, mainly because the construction of shrimp farms required extensive areas of saline waters (Arriaga 2000). The particular detriment of mangroves caught the attention of Stephen Olsen, thenDirector of the Coastal Resource Center at the Rhode Island University (CRC-URI). Olsen teamed up with Howard T. Odum, an American pioneer on ecosystem ecology, to analyze the relationship between the ecological and economic processes of shrimp farming in Ecuador. The final report issued in 1991 opens the discussion with the following statement:

"The [shrimp farming] industry has, in a mere fifteen years, become Ecuador's second largest earner of foreign exchange. It has also brought greater changes to the country's coastal ecosystem than any other human activity. The industry has, with minor exceptions, transformed every estuary by the construction of ponds in former salt flats and mangrove wetlands, channelizing water flow and in some cases significantly altering water quality. Through the capture of seed shrimp and egg-bearing females, the industry has increased the pressures on all estuarine fisheries. It has also brought employment, and, to some, great wealth" (Odum \& Arding 1991, i). 
Indeed, the shrimp industry in Ecuador requires extensive estuarine areas where salinity levels are vital for the growth of shrimp. Initially, this industry also depended on the natural larvae captured in the sea. The seed shrimp were transferred to large shrimp ponds to complete their growth cycle. In Ecuador, larveros' or shrimp larvae collectors' contribution to the shrimp industry tripled in fifteen years, from seven billion seed shrimp in 1986 to twenty-four billion in the year 2000 (Arriaga 2000). In Santa Elena, the 1993 Manglaralto Management Plan (CRMO 1993) estimates that more than $80 \%$ of the economically active population in the parish of Manglaralto collected shrimp larvae during the aguajes, periods of high tides. Consequently, for an average of sixteen days per month, the agricultural laborers abandoned their crops and went into the sea to collect shrimp larvae. In Santa Elena, the larveros collected shrimp larvae in two ways. 1) Artisanal fishing at 25-50 meters offshore, operating pangas or boats adapted with conic nets and floaters made out of mangrove. 2) At the surf zone area, the larveros collected shrimp-larvae with manually handled nets. This artisanal method for capturing shrimplarvae produced high mortality of shrimp and other species while conflicting with the incipient tourism in the north of Santa Elena peninsula (Arriaga 2000, PMRC 1993). Thus, Ecuador's shrimp industry threatened mangroves and the natural shrimp cycle in the sea.

The Coastal Resource Management Program (CRMP) addressed the effects of the shrimp industry on the coast of Ecuador. As I show in chapter 5, the program operated from 1986 to 2008, the time when Ecuadorian governments adopted neoliberal state practices. During the first phase (1986-2003), the program applied Integrated Coastal Management (ICM) methodology. The CRC-URI had successfully experienced ICM in 
some US coastal areas since the 1970 s and partnered with USAID to test the ICM in tropical countries. From 1994 when the project entered its implementation phase, the Inter-American Development Bank (IDB) funded the CRMP until it concluded.

Initially, the coastal management program included the ecological impact of Santa Elena's larveros. The provision of natural shrimp-larvae to the shrimp industry could cause the collapse of the natural shrimp life cycle in the sea. As shown in Chapter 5, after several initiatives, the CRMP changed Ecuadorians' behavior on the use and abuse of coastal ecosystems and promoted locals' entrepreneurship capability. For achieving those goals, the ICM operated the Two-Track Strategy, a co-management that included collaborative participation and decentralization. At the national level, CRMP addressed environmental degradation by legal frameworks, banning mangrove exploitation and controlling shrimp-farming permits for use in estuarine areas. At the local level, CRMP raised consciousness on the ecological damage the shrimp industry had introduced to comuneros' communal lands, while the participatory process of decision making disclosed novel forms of sustaining livelihoods.

The longitudinal analysis of the CRMP's operation also reveals that its initial concern for environmental conservation turned into adopting sustainable development criteria, particularly after the IDB funded the project. Sustainable development was emerging globally in the late 1990s. According to the UN, sustainable development was the solution to the need for developing local economies and protecting the environment. Indeed, by early 2000, when Ecuador signed a second IDB contract, sustainable development "c[ame] to be viewed increasingly as the potential bearer of an alternative security paradigm" (Doran 2002, 12). In the Ecuadorian coastal areas, the second IDB 
loan devoted to CRMP's operation targeted mainly poverty alleviation, understood as the problem of underdeveloped countries, while putting aside the ICM approach.

By the end of the 1990s, the shrimp industry had almost collapsed. The 1997/1998 ENSO deeply impacted the shrimp farming cycle, and, later on, the outbreak of a severe shrimp disease decreased shrimp production (Chapter 3). ENSO 1997/1998 damaged the shrimp larvae-based economy at the north of Santa Elena. Thus, as I showed in Chapter 3, people in Santa Elena strengthened their capacity to rebuild their social lives by embarking on community tourism and handicrafts. It was an alternative the CRMP had already promoted on the coast of Ecuador. The CRMP continued supporting and promoting small-scale tourism entrepreneurship, community-operated Hospederias Comunitarias, and a few of other tourism-related businesses. Accordingly, Santa Elena was to achieve economic and resource sustainability through tourism development. Small-scale business tourism was less harmful than the extensive shrimp industry. More importantly, CRMP's collaborative participation techniques allowed locals decision-making over their common-property land as well as the defense of their territories (Chapter 5). In Community Assemblies, locals discussed the new opportunities CRMP was bringing to their comunas, mainly tourism. Small-scale business tourism development fit with their cash-strapped economy. As I pointed out in chapter 6, since the CRMP started, community tourism had revitalized livelihoods in seaside comunas of Santa Elena. Comuneros are now entrepreneurs, while the community decides social, economic and environmental arrangements in their territory. Many comuneros in Santa Elena operate their own small-scale tourism businesses, employ wage-labor, pay fees, promote their business, and decide over their lands and their wellbeing. 
Thus, the coastal management program in Ecuador inserted the comuneros into "the machinery of production and the adjustment of the phenomena of the population to economic processes" (Foucault 1978, 141). Paraphrasing Julian Reid (2013), CRMP’s development criteria reduced comuneros' lives to an economized form, by which development becomes synonymous with economic improvement. However, the classical biopolitical critique of development argues that it "functions to subject people to economization of life of the subject and its society" (Reid 2018, 645). Thus, a biopolitical approach to CRMP's effects on Santa Elena reveals that comuneros were made subjects of Western forms of development, highly influenced by the marketization of their labor and their livelihoods.

Nonetheless, the small-scale tourism development Santa Elena undertook in the late 1990s (Chapter 6) instantiates "how vulnerable the ecological reasoning that underpins sustainable development has been to the economic reasoning of neoliberalism" (Reid 2018, 645). After the CRMP intervention, sandy beaches had become a vital resource for the economy of the comunas, the Parish of Manglaralto, and the Canton of Santa Elena. Comuneros' economy relies on beach ecological, recreational and economic value. On the beach, the comuneros have built the cabanas, the primary source for the community economy circulation. Many of the cabanas are occupying the natural areas, such as seagrass areas and berms (Chapter 6), which are needed to protect the beach from erosion. Indeed, tourism-led development has exacerbated the use of the beach ecosystem.

Reid concludes the quote I cited in the previous paragraph by pointing out the vulnerability of ecosystems in front of the economic reasoning of neoliberalism. 
However, the case of Ecuador is different. The ecological reasoning underpinning smallscale tourism business development was more subsumed under the anti-neoliberal government ruling Ecuador from 2007-2017. On the one hand, the anti-neoliberal rationale found the tourism development of Santa Elena crucial for the endogenous development and solidarity economy which the government pursued (Chapter 3) and on the other hand, the risk management security rationale armored the beaches to protect the population from floods, ENSO or tsunamis (Chapter 4). As I will explain in the following paragraphs, Santa Elena's beach ecosystem is currently vulnerable to economic and risk management reasoning.

In 2009, the comuneros of Libertador Bolívar self-organized to transform the north beach into a promenade (Chapter 6). Later on, in 2015, the demand for the promenade construction turned into claims for protection of the population. On many occasions, intense waves run up the beach, impacting beachfront infrastructure and destroying the cabanas, while the sandy beaches momentarily disappeared. Destruction increases when high tide converges with the moon syzygy. Evidently, when both concur with the ENSO phenomenon, catastrophic damage could result. Ultimately, this natural process of waves running up and down creates beach erosion. Indeed, small but increasingly frequent impacts can change the very nature of a system (Davoudi 2012). Additionally, the anthropic intervention of the beaches, such as seagrass removal and berm occupancy, also increases beachfront infrastructures' vulnerability to high tides. Consequently, the tourism-led economy and populations' security are now at risk. Thus, while the solution to the ecological degradation of coastal resources was to shift toward a 
market economy, twenty years later the tourism market has generated the problem of security for comuneros.

Thus, in response to the increasingly frequent rise in sea level - mainly present during the aguajes, and the emergency claims demanded by the comuneros, the municipal government has built seawalls in several seaside villages in Santa Elena (Chapter 6). The Risk Management criteria, introduced in Ecuador during the antineoliberal decade, considered engineering a structural measure to mitigate populations' vulnerability to the effects of rising sea level (Chapter 4). Between 2016 and 2017, the local government built retaining walls at the river mouth and a seawall on the north beach in the comuna of Libertador Bolívar, and now in 2019, the seawall underpins the tourismled economy and the wellbeing of the comuna. On top of the seawall, the municipal government built the promenade, an initiative the comuneros started in 2009. Alongside the promenade, thirteen cabanas are currently the new tourist attraction of Libertador Bolívar; tourists enjoy the sandy beach and local gastronomy. Locals take advantage of peak tourist seasons while they are aware that the waves might batter the beach at any moment. The ongoing security issue detailed in the previous paragraphs justified changing the very nature of the beaches. The socio-ecological relationship between the beach and the locals keeps shifting between the constant nature, development and security problematization that justifies continuous ecological deterioration, whether the government is neoliberal or anti-neoliberal. 


\section{CHAPTER VIII}

\section{Conclusions}

My dissertation traces a genealogy of neoliberal and anti-neoliberal resilience organizing coastal rural lives in Ecuador, to understand how practices of resiliencebuilding morph alongside new ways of governing lives. In doing so, my work posits a critique of current discussions of resilience that view the concept as embedded in neoliberal governmental rationalities. On the one hand, the research charts the development and deployment of adaptive management criteria that underpinned sustainable development programs during the late 90s and early 2000s, when Ecuadorian governments ruled the country through neoliberal practices. On the other hand, an antineoliberal government ruling Ecuador from 2007-2017 deployed resilience criteria through disaster and risk reduction management.

Thus, longitudinal analysis of Ecuadorian governance of comuneros' economic and environmental relations reveals how Ecuadorian governments, whether ruling through neoliberal or anti-neoliberal practices, have both relied on elements from wider discourses on resilience, which ultimately justify governmental intervention to secure the population's growth and development in the face of uncertain futures. Indeed, both neoliberal and anti-neoliberal governments have promoted tourism-led development strategies within comuneros' communities. Both neoliberal and anti-neoliberal interventions in coastal villages implemented similar techniques, such as legal regulations, various form of decentralization, unique styles of technocratic planning, and 
participatory adaptive management. But importantly, each style of governance deployed distinct constellations of these techniques in response to specific problems of social and environmental change. For example, the tourist economy in rural Santa Elena is now threatened by increasingly frequent of waves and sea-level rise at Santa Elena's beaches, particularly during El Niño phenomenon. But waves pummeling Santa Elena's beaches did not meet the national government's categorization of a natural disaster. Instead, the local government responded after locals demanded the protection of their villages. Thus, as this dissertation demonstrate, diverse approaches to resilience-building reflect distinct governmental strategies to secure tourist-led development against social and environmental uncertainties. Thus, while many scholars have become dismissive of resilience for its close ties to neoliberal governance reforms, this dissertation shows how the particular form resilience takes is shaped by shifting and dynamic relations between prevailing governmental ideologies, uncertain environmental impacts, and the effectiveness of public demands for government response to these impacts.

\section{Research contribution}

The current dissertation analyzes a unique collection of resilience policies in both neoliberal and anti-neoliberal governments. It contributes to critical resilience scholars' endeavor to capture resilience malleability by which it transcends contexts and institutions. As a result, this research furthers scholarship mainly focused on the ubiquitousness of neoliberal resilience. Indeed, critical resilience thinkers' emphasis on neoliberal institutionalization of resilience is actually replicating what they critique, overlooking other alternatives. My post-colonial approach brings to academia a case from a politically unstable country in general, and from coastal rural lives in particular. By 
emphasizing small quotidian events rather than catastrophic events, this dissertation captures the constructive role of local emergency claims - frequently missed in the analysis of complex interconnections. Additionally, those slow emergencies in Santa Elena disclosed local decisions on the use of natural resources and locals' co-existence with increasingly frequent tidal threats. Local decisions over, and co-existence with, coastal threats largely counter the Western hegemonic approaches to risk.

Replication of this longitudinal transformation's analysis can provide insights in contested spaces between nature, population, and mechanisms of governance. The methodology I applied to understand the indeterminacy of complex interconnections includes: 1) the adoption of resilience as a style of thought to transgress socialinstitutional interplay with nature. As a style of thought, resilience shines light on reciprocal feedback between the social and the ecological components of the system that take place within nature, development, and security arrangements. 2) A genealogy of resilience on the coast of Ecuador allows for the unfolding of how resilience constitutes a governmental security technique, operating in multiple processes and morphing alongside ways of governing life. 3) A process-tracing methodology allows breaking the longitudinal analysis to observe changes and sequences of small and local events. Overall, this dissertation emphasizes small but quotidian events, the slow emergencies, rather than catastrophic events to capture the constructive role of local emergency claims in complex adaptive systems' feedback loops.

My contribution exceeds conventional critiques of institutions that wield power over the population. In stark contrast, my case combines the analysis of powerful global and national institutions ruling Ecuadorians' lives with local claims on emergency that 
focus on the slight but chronic local effects on nature. In doing so, the history of coastal lives sets new directions for research on how local socio-natural struggles are increased by climate change. Thus, my dissertation moves debates of resilience from a mere critique of the effects of resilience thinking to unveil resilience in the realm of politics.

\section{Limitations}

Despite the richness of regulatory practices and local voices captured throughout my dissertation, the lack of data regarding Santa Elena frustrated me during my longitudinal analysis. Few and separate anthropological, sociological, or geographical accounts regarding rural lives on the coast of Ecuador exist. Anthropological work published during the 1980s and 1990s continues to be the only source shedding light on current research in Santa Elena. Similarly, little technical data specific to rural areas in Santa Elena exist. For instance, census data collects population and macro-economic information at the parish level but does not categorize data regarding communal administrative divisions.

Similarly, neither the tourism ministry nor the municipal tourism office accurately records Santa Elena's tourism business in rural areas. As shown in my research, coastal rurality in Santa Elena exists within interstices where national laws and regulations contradict one another. Finally, I acknowledge that I have not developed discussions on the political ecology of water despite focusing on hydro-meteorological threats in coastal zones. Indeed, my interest throughout this research focused on critiquing resilience analyses and practices while paving the way towards a political ecology of resilience, which ideally should be part of further research. 


\section{Further research}

This research has traced resilience in a country characterized by political instability, uncovering almost thirty years of policies based on resilience. Thus, research on resilience implementation and effects in countries with political instability, or characterized by state rule rather than neoliberal rule, can shed light on resilience discussions and critiques. The analysis of the effects of coastal resource management programs introduced in tropical countries under the criteria of ecological resilience remains unclear. Thus, future research should take into account the original resilience ecology criteria that contributes to the political ecology of resilience. Finally, the analysis of disaster-led resilience should shift the focus to slow, small, and chronic emergencies. 


\section{List of cited references}

Adams, W. M. 2009. Green Development Environment and sustainability in a developing world. 3rd. Edition vols. Lodon and New York: Routledge.

Adgel, Neil, Terry Hughes, Carl Folke, Stephen Carpenter, and Johan Rockstrom. 2005. "Socio-Ecological Resilience to Coastal Disasters." Science 309: 1036-1039.

Adger, Neil W. 2000. "Socio and Ecological Resilience: Are they related?" Human Geography 24 (3): 347-364.

Agnew, John. 1994. "The Territorial Trap: The Geographical Assumptions of International Relations Theory." Review of International Political Economy 1 (1): 53-80.

Agrawal, Arun. 2005. "Community, Intimate Government, and the Making of Environmental Subjects in Kumaon, India." Current Anthropology 46 (2): 161190.

Alvarez, Silvia. 1999. De Huancavilcas a Comuneros. Relaciones interétnicas en la Península de Santa Elena, Ecuador. Quito: Abya-Yala.

Alvarez, Silvia. 2002. Etnicidades en la costa Ecuatoriana. Quito: Ediciones Abya-Yala.

Anderson, Ben. 2011. "Affect and biopower: towards a politics of life." Transactions of the Institiute of British Geographers 37 (1): 2-16.

Anderson, Ben. 2010. "Preemption, precaution, preparedness: anticipatory action and future geographies." Progress in Human Geography 34 (6): 777-798.

Anderson, Ben. 2015. "What kind of thing is resilience?" Politics 35 (1): 60-66.

Anderson, Ben, Kevin Grove, Lauren Rickards, and Mathew Kearnes. 2019. "Slow Emergencies: temporality and the racialised biopolitics of emergency governance"." Progress in Human Geography 1-19.

Arandau, Claudia. 2015. "The promise of security: resilience, surprise and epistemic politics." Resilience: International Policies, Practices and Discourses 2 (2): 1-15.

Arriaga, Luis. 2000. Manejo Costero Integrado (ICM) del Ecuador. Cabeza de Playa hacia el Desarrollo Costero Sustentable. Guayaquil: Fundación Pedro Vicente Maldonado.

Arsel, Murat. 2012. "Between "Marx and Markets?" The State, the Left Turn and nature in Ecuador." Journal of Economic \& Social Geography 150 - 163. 
Assembly, Ecuadorian National. 2008. "Constitution." Constitution. Quito: National Assembly, October 20.

Avellar-Mascarello, Marcela, Martin García-Cartagena, and Eddy Jara-Torres. 2014. "Procesos de Manejo Costero Integrado en Ecuador y Sri Lanka: Una perspectiva de comparacion." Revista Intertropica 43 (9): 43-59.

Balibar, Étienne. 2004. We the People of Europe? Reflections on Transnational Citizenship. Princeton: Princeton University Press.

Barker, Mary Tuti. 2011. "Resisting Neoliberal Capitalism: Sustainable Selfdetermination on Moloka 'i, Hawai i." International Journal of Critical Indigenous Studies 4 (1): 12-21.

Barnett, Clive. 2005. "The consolotions of 'neoliberalism'." Geoforum 36: 7-12.

Bauer, Daniel. 2018. Identity, Development, and the Politics of the Past: An Ethnography of Continuity and Change in a Coastal Ecuadorian Community. Louisville: University Press of Colorado.

Bazurco, Martín. 2006. "Yo soy más Indio que tú" Resiginificado de la Etnicidad. Exploración Teórica e Introducción al Proceso de Reconstrucción Etnica en las Comunas de la Península de Santa Elena, Ecuador. Quito: Abya-Yala.

Beavers, Rebecca, Amanda Babson, and Courtney Schupp. 2016. Coastal Adaptation Strategies Handbook. Lakewood: National Park Service.

Becker, Marc. 2011. ;Pachakutik! Indigenous Movements and Electoral Politics in Ecuador. Maryland: Rowman \& Littlefield.

Becker, Marc. 1999. "Comunas and Indigenous Protests in Cayambe, Ecuador." The Americas 55 (4): 531-559.

Becker, Marc. 2013. "Ecuador. Indigenous Struggles and the Ambiguity of Electoral Power." In The New Latin American Left. Cracks in the Empire, by Jeffery R. Webber and Barry Carr, 213-232. New York: Rowman \& Littlefield Publishers.

Berkes, F., C. Duffield, and L. Ham. 1996. "Livelihood Systems, Adaptive Strategies and Sustainability Indicators in the Western Indian Himalaya." Voices from the Commons 6th Annual Common Property Conference. Winnipeg: Natural Resources Institute/University of Manitoba. 1-44.

Berkes, Fikret. 2006. "From Community-Based Resource Management to Complex Systems: The Scale Issue and Marine Commons." Ecology and Society 11 (1(45)). 
Berkes, Fikret. 2010. "Shifting perspectives on resource management: Resilience and the Reconceptualization of 'Natural Resources' and 'Management." Maritime Studies 9 (1): 13-40.

Berkes, Fikret, and Carl Folke. 1994. Linking Social and Ecological Systems for Resilience and Sustainability. Discurssion Paper Series No 52, Stockholm: Beijer International Institute of Ecological Economics.

Berkes, Fikret, and Helen Ross. 2012. "Community Resilience: Toward an Integrated Approach." Society \& Natural Resources 26 (1): 5-20.

Berkes, Fikret, Carl Folke, and M Gadgil. n.d. "Traditional Ecological Knowledge, Biodiversity, Resilience and Sustainability." In Biodiversity Conservation Problems and Policies, by C. A. Perrings, K. G. Mäler, C. Folke, C. S. Holling and B. O. Jansson, 281-299. Dordretch: Kluwer Academic Publisher.

Berkes, Fikret, Johan Colding, and Carl Folke. 2003. Navigating Social-Ecological Systems. Building Resilience for Complexity and Change. Cambridge: Cambridge University Press.

Birch, Tarci, and Enrique Reyes. 2018. "Forty years of coastal zone management (19752014): Evolving theory, policy and practice as reflected in scientific research publications." Ocean \& Coastal Management 153: 1-11.

Brown, Katrina. 2003. "Integrating conservation and development: a case of institutional misfit." Frontiers in Ecology and the Environment 9 (1): 479-487.

Brown, Katrina. 2016. Resilience, Development and Global Change. New York: Routledge.

Burbano, Gustavo Paredes. 1998. Ecuador: Evaluación de los logros durante el Decenio. Assessment, Quito: UNDRR.

Cabanilla, Enrique. 2018. "Turismo comunitario en América Latina, un concepto en construcción." Siembra 5: 121-131.

CAF. 1998. Las Lecciones de El Niño Ecuador. Memorias del Fenomeno de El Niño 1997-1998. Retos y Propuestas para la Region Andina. Memorias, Ecuador: Corporacion Andina de Fomento.

Caille, Guillermo, Emilio Ochoa, and Stephen Olsen. 2007. "Para mejorar la gobernabilidad sobre los cambios en los ecosistemas costeros de Latinoamérica." In Ocho Caminos para la integración inter-territorial Latinoamericana, by Bernardo Toro. Bogotá: Fundación Avina.

CAN. 2002. "Decisión 529. Creación del Comité Andino para la Prevención y Atención de Desastres (CAPRADE)." Regional Document. Lima: CAN, July 7. 
Canessa, Andrew. 2005. Natives Making Nation. Gender, Indigeneity, and the State in the Andes. Tucson: University of Arizona Press.

Cano, Daniel Rodrigo, María José Pico, and Glenda Dimuro. 2019. "The Sustainable Development Goals as a base for the action and social and environmental intervention." Retos. Journal of Administration Sciences and Economics 9 (17): $25-35$.

Carrión, Andrea, Isabella Giunta, Anita Mancero, and Gualdemar Jimenez. 2017. PostTerremoto, Gestión de Riesgos y Cooperación Internacional: Ecuador. Quito: Editorial IAEN.

Castillo, Maria Jose, and Richard Beilock. 2004. "Selling their Best for Little: The Riddle of Ecuador's Failed Attempt to Assist Communal Farmers." Revista Latinoamericana de Desarrollo Economico 2: 123-142.

Cattelino, Jessica. 2006. "Florida Seminole Housing and the Social Meanings of Sovereignty." Society for Comparative Study of Society and History 48 (3): 699726.

Cedeño Zambrano, Héctor. 2017. Planificación Urbana aplicada en asentamientos Indígenas. Estudio de caso comuna de Montañita, Ecuador. Manta: Editorial Mar Abierto.

Chandler, David. 2014. "Beyond neoliberalism: resilience, the new art of governing complexity." Resilience: International Policies, Practices and Discourses 6 (3): 47-63.

Chandler, David. 2015. "Reconceptualizing International Intervention: State building, 'Organic Processes' and the Limits of Causal Knowledge." Journal of Intervention and Statebuilding 9 (1): 70-80.

Chandler, David. 2012. "Resiience and human security: The post-interventionist paradigm." Security Dialogue 43 (3): 213-229.

Chandler, David. 2013. "Resilience ethics: responsibility and the globally embedded subject." Ethics \& Global Politics 6 (3): 175-194.

Chandler, David, and Julian Reid. 2016. The Neoliberal Subject Resilience, Adaptation, and Vulnerability. London and New York: Rowman \& Littlefield International.

Chapman, Maura G., and Anthony J. Underwood. 2011. "Evaluation of ecological engineering of "armoured" shorelines to improve their value as habitat." Journal of Experimental Marine Biology and Ecology 400 (1-2): 302-313. 
Coaffe, Jon, and Pete Fussey. 2015. "Constructing resilience through security and surveillance: The politics, practices and tensions of security-driven resilience." Security Dialogue 46 (1): 86-105.

Coleman, Mathew, and Kevin Grove. 2009. "Biopolitics, biopower, and the return of sovereignty." Environment and Planning 27: 489-507.

Collier, David. 2011. "Understanding Process Tracing." Political Science and Politics 44 (4): 823-830.

Collier, Stepehn. 2009 . "Topologies of power: Foucault's analysis of political government beyond 'governmentality'." Theory, culture \& Society 78-108.

Collier, Stephen. 2011. Post-Soviet Social: Neoliberalism, Social Modernity, Biopolitics. New Jersey: Princeton University Press.

Commission of Marine Science, Engineering and Resources. 1969. Our Nation and The Sea. A Plan for National Action. Plan, Washington D.C.: United States Government Printing Office.

CONADES. 1996. "Plan de Accion del Gobierno 1993- 1996." Agenda para el Desarrollo. Quito: CONADES, January 02.

Coraggio, Jose Luis, and Jean-Louis Laville. 2014. Reinventar la Izquierda en el Siglo XXI. Hacia un dialogo Norte-Sur. Buenos Aires: Universidad Nacional de General Sarmiento.

Cornejo, Pilar. 2007. Human Development Report 2007/2008 Fighting climate change: Human solidarity in a divided world. Quito: Human Development Report Office.

Correa, Rafael. 2009. Ecuador: de Banana Republic a la No Republica. Quito: Debate.

CPR-AeA. 2014. Sistematización del Proceso de Intervención en Comunas de las Parroquias Colonche y Manglaralto. Area de Desarrollo Territorial Santa Elena. Santa Elena: CPR.

Cummings, Graeme S., Craig R. Allen, Natalie C. Ban, Duan Biggs, Harry C. Biggs, David H.M. Cumming, Alta De Vos, et al. 2015. "Understanding protected area resilience: a multiscale, social-ecological approach." Ecological Applications 25 (2): 299-319.

Cushnahan, Gavan. 2003. "Crisis Management in Small-Scale Tourism." Journal of Travel \& Tourism Marketing 15 (4): 323-338.

Davis, Jeffrey Sasha. 2005. "Representing Place: "Deserted Isles" and the Reproduction of Bikini Atoll." Annals of the Association of American Geographers 95 (3): 607625 . 
Davoudi, Simin. 2016. "Resilience and Governmentality of Unknowns." In Governmentality after Neoliberalism, by M. Bevir. London: Routledge.

Davoudi, Simin. 2012. "Resilience: A bridging Concept or a Dead End?" Planning Theory \& Practice 13 (2): 299-233.

Davoudi, Simin, and A Madanipour. 2015. "Localism and post-social governmentality." In Reconsidering Localism, by Simin Davoudi and A Madanipour, 77-103. London: Routledge.

Davoudi, Simin, Elizabeth Brooks, and Mehmood Abid. 2013. "Evolutionary Resilience and Strategies for Climate Adaptation." Planning Practice \& Research 28 (3): 307-322.

De La Cadena, Marisol. 2010. "Indigenous Cosmopolitics in the Andes: Conceptual reflections beyond "Politics"." Cultural Anthropology 25 (2): 334-370.

De La Torre, Carlos. 2010. "Gobierno de Rafael Correa: Posneoliberalismo, confrontacion con los movimientos sociales y democracia plesbiscitaria." Temas y Debates 14 (20): 151-172.

Dean, Mitchell. 2010. Governmentality. Power and Rule in Modern Society. London: Sage Publications Ltd.

Demoraes, Florent, and Robert D'Ercole. 2001. Cartografia de las Amenazas de Origen Natural por Cantón en el Ecuador. Quito: COOPI, OXFAM, SIISE.

D'Ercole, Robert, and Monica Trujillo. 2003. Amenazas, vulnerabilidad, capacidades y riesgo en el Ecuador. Los Desastres, un reto para el desarrollo. Quito: COOPI, OXFAM, IRD.

Diario E1 Telegrafo. 2012. Fundacion Natura cierra sus puertas en el pais. Guayaquil, Guayas, October 10.

Diedrich, Amy, Claudia Benham, Lina Pandihau, and Marcus Sheaves. 2019. "Social Capital plays a central role in transitions to sportfishing tourism in small-scale fishing communities in Papua New Guinea." Ambio 48: 385-396.

Dietz, Thomas, Elinor Ostrom, and Paul C. Stern. 2003. "The Struggle to Govern the Commons." Science 32 (5652): 1907-1912.

Dillon, Michael. 1995. "Sovereignty and Governmentality: From the Problematics of the "New World Order" to the Ethical Problematic of the World Order." Alternatives: Global, Local, Political 20 (3): 323-368.

Doran, Peter. 2002. World Summit on Sustainable Development (Johannesburg)-An assessment for ISSD. Johanesburgh: International Institute for Sustainable Development 
Dunn Cavelty, Myriam, Mariele Kaufman, and Kristina Soby Kristensen. n.d. "Resilience and (in)security: Practices, subjects, temporalities." Security Dialogue 46 (1): 314.

Eaton, Kent. 2013. "The Centralism of 'Twenty-First-Century Socialism': Recentralising Politics in Venezuela, Ecuador and Bolivia." Journal of Latin American Studies 45 (3): 421-450.

EFE. 2009. "Termina 'larga noche neoliberal'." La Hora Nacional. December 09. Accessed February 25, 2017. http://lahora.com.ec/index.php/noticias/show/509050\#.WOgwX9wbd04.

El Comercio. 2019. "Aguaje y Oleaje vuelven a causar danos en balnearios de Santa Elena." El Comercio, January 24.

El Comercio. 2009. "Cuatro zonas costeras son vulnerables ante los aguajes Este contenido ha sido publicado originalmente por Diario EL COMERCIO en la siguiente dirección: https:/www.elcomercio.com/actualidad/cuatro-zonascosteras-son-vulnerables.html. Si está pensando en ." El Comercio, October 7.

El Comercio. 2015. "La Costa Ecuatoriana se enfrenta esta semana a los aguajes." El Comercio, May 3.

El Universo. 2015. "17 provincias en estado de excepción ante eventual llegada de E1 Niño." El Universo, November 2015.

El Universo. 2004. "De Guayaquil a Montañita, en bus." El Universo, February 25.

El Universo. 2018. "Declararon emergencia por oleajes en Libertador Bolívar." El Universo, September 18.

El Universo. 2007. "Lo gastronómico busca ser referente en las comunas." El Universo, March 31.

El Universo. 2011. "Oleaje y aguaje coinciden y se sugiere precaución." El Universo, April 2.

El Universo. 2016. "Onda kelvin haría que El Niño se debilite, dice Erfen." El Universo, Febrero 23.

El Universo. 2003. "Playas alternativas para la temporada." El Universo, December 07.

El Universo. 2017. "Réplica: De la Secretaría de Gestión de Riesgos." El Universo, March 20.

El Universo. 2002. "Taller para prevenir efectos de El Niño." El Universo, August 09. 
Epler, Bruce, and Stephen Olsen. 1993. A Profile of Ecuador's Coastal Region . Technical Report Series: TR2047, Ecuador: USAID.

Erazo, Juliet S. 2013. Governing Indigenous Territories. Enacting Sovereignty in the Ecuadorian Amazon. Durham: Duke University Press.

Escobar, Arturo. 2008 . Territories of Difference: place, movements, life, redes. Duke University Press.

Escobar, Arturo. 2007. La invención del Tercer Mundo Construcción y deconstrucción del desarrollo. Caracas: Fundación Editorial El Perro y la Rana.

Escobar, Arturo. 1999. "After Nature: Steps to an Antiessencialist Political Ecology." Cultural Anthropology 40 (1): 1-30.

Escobar, Arturo. 1995. Encountering Development: The Making and Unmaking of the Third World. Princeton: Princeton University Press.

Evans, Brad, and Julian Reid. 2015. "Exhausted by resilience: response to the commentaries." Resilience. International Policies, Practices and Discourses 3 (2): $154-159$.

Felicetti, Gianlucca. 2016. "The Concept of Resilience Applied by Local Communities in Protected Area as Social-Economic-Ecological Systems (SEES)." Calitatea 17: 74-78.

Ferguson, James. 1994. The Anti-politics Machine. Development, Depolitization, and Bureaucratic Power in Lesotho. New York: Cambridge University Press.

Ferguson, James, and Larry Lohmann. 1994. "The Anti-politics Machine. Development and Bureaucratic Power in Lesotho." The Ecologists 24 (5): 176-181.

Fixico, Donald. 2013. Indian Resilience and Rebuilding. Arizona: University of Arizona.

Folke, Carl. 2016. "Resilience (Republished)." Ecology and Society 21(4) (44): no pagination.

Folke, Carl. 2006. "Resilience: The emergence of a perspective for social-ecological systems analyses." Global Environmental Change 16: 253-267.

Folke, Carl, and Fikret Berkes. 1992. Cultural Capital and Natural Capital Interrelations. Beijer Discussion Paper Series No. 8, Stockholm: Beijer International Institute of Ecological Economics, The Royal Swedish Academy of Science.

Folke, Carl, and Thomas Hahn. 2005. "Adaptive Governance of Social-Ecological Systems." Annual Review of Environment and Resources 15: 441-473. 
Folke, Carl, Pitchard Jr. Lowell, Fikret Berkes, Johan Colding, and Uno Svedin. 2007. "The Problem of Fit between Ecosystems and Institutions: Ten Years Later." Ecology and Society 12(1) (30): no pagination.

Folke, Carl, Stephen R. Carpenter, Brian Walk, Marten Scheffer, Terry Chapin, and Johan Rockström. 2010. "Resilience Thinking: Integrating Resilience, Adaptability, and Transformability." Ecology and Society 15(4) (20): no pagination.

Foucault, Michel. 2008. The Birth of Biopolitics. Lectures at College of France 19781979. New York: Palgrave Macmillan.

Foucault, Michel. 2007. Security, Territory, Population. Edited by Michell Senelart. Translated by Graham Burchel. UK: Palgrave MacMillan.

Foucault, Michel. 2003. Society Must Be Defended. Lectures at the College De France 1957 - 1976. New York: Palgrave.

Foucault, Michel. 1997. The Politics of Truth. New York: Semiotext(e).

Foucault, Michel. 1991. "Governmentality." In The Foucault Effect, by Graham Burcher, Gordon Collier and Michael Peters, 87-104. Chicago: University of Chicago Press.

Foucault, Michel. 1982. "The Subject and Power." Critical Inquiry 777-795.

Foucault, Michel. 1978. The History of Sexuality. Volumen I: An Introduction. Translated by Robert Hurley. New York: Pantheon Boos.

Frerks, George, Jeroen Warner, and Bart Weijs. 2011. "The Politics of Vulnerabiity and Resilience." Ambiente \& Sociedade XIV (2): 105-121.

Gadgil, M., F. Berkes, and C. Folke. 1993. "Indigenous Knowledge for Biodiversity Conservation." Ambio 22 (2/3): 151-156.

GAD-M. 2011. "Plan de Desarrollo y Ordenamiento Territorial GAD Manglaralto 20112016." Santa Elena: Fundación Santiago de Guayaquil.

GAD-M. 2014. "Plan de Desarrollo y Ordenamiento Territorial GAD Manglaralto 20142019." Santa Elena: GestionAdmi Cia. Ltda.

GAD-MSE. 2016. "Resolución 0108082015. Declaración de Emergencia de Libertador Bolívar y Las Nunez." Santa Elena: Municipalidad de Santa Elena, August 08.

GAD-MSE. 2009. Plan de Contingenica por Inundaciones. Plan, Santa Elena: GADMSE. 
GAD-PSE. 2015. "Resumen Ejecutivo del Plan de Desarrollo y Ordenamiento Territorial Provincial 2015 - 2019." Santa Elena: GAD Provincia de Santa Elena.

Gamso, Jonas. 2016. "A Case of Diversified Dependency Macrostructural Change and Policy Alternatives in Ecuador." Latin American Perspectives 43 (1): 109-123.

García-Garizabal, Iker, Paola Romero, Samantha Jimenez, and Luis Jorda. 2017. "Climate Change effects on the climate dynamics of coastal Ecuador." DYNA 84 (203): 37-44.

Gasparri, Enrico, Carlo Tassara, and Margarita Velasco. 1999. El fenomeno de El Niño en Ecuador 1997 1999. Del Desastre a la prevencion. Quito: Ediciones Abya - Yaia.

GESAMP. 1996. The Contributions of Science to Integrated Coastal Management. Rome: FAO.

Giddens, Anthony. 1999. "Risk and Responsibility." The Modern Law Review 62 (1): 110.

Giddens, Anthony. 1984. The Constitution of Society: Outline of the Theory of Structuration. Berkeley: University of California Press.

Goertzel, Ted. 2008. "Rethinking Socialism in Today's Latin America." In A Changing Cuba in a Chainging World, by Maurcio A. Font, 287-294. New York: Bildner Center for Western Hemisphere Studies.

Grove, Kevin. 2018a. Resilience. Abington: Routledge.

Grove, Kevin. 2018b. "Biopolitics." In Companion to Environmental Studies, by Noel Castree, Mike Hulme and James D. Proctor, no pagination. Abingdon: Routledge

Grove, Kevin. 2014a. "Agency, affect, and the immunological politics of disaster resilience." Environment and Planning 32: 240-256.

Grove, Kevin. 2014b. "Biopolitics and Adaptation: Governing Socio-Ecological Contingency Through Climate Change and Disaster Studies." Geography Compass 8 (3): 198-210.

Grove, Kevin. 2013a. "From Emergency Management to Managing Emergence: A Genealogy of Disaster Management in Jamaica." Annals of the Association of American Geographers 1033 (3): 570-588.

Grove, Kevin. 2013b. "Hidden Transcripts of resilience: power and politics in Jamaican Disaster Management." Resilience: International Policies, Practices and Discourses 1 (3): 193-209. 
Grove, Kevin, and David Chandler. 2017. "Resilience and the Anthropocene: the stakes of 'renaturalising' politics." Resilience 5 (2): 79-91.

Grove, Kevin, and Jonathan Pugh. 2015. "Assemblage Thinking and Participatory Development: Potentiality, Ethics, Biopolitics." Geography Compass 1 (13): 113.

Grove, Kevin, and Peter Adey. 2015. "Security and the Politics of Resilience: An Aesthetic Response." Politis 35 (1): 78-84.

Gudynas, Eduardo. 2016. Derechos de la naturaleza ética biocéntrica y políticas ambientales. Quito: Edicitones Abya-Yala.

Gudynas, Eduardo. 2011. "Desarrollo y Sustentabilidad Ambiental: Diversidad de Posturas, Tensiones persistentes." In La Tierra no es muda: Dialogos entre el Desarrollo Sostenible y el Postdesarrollo, by Alberto Mataran Ruiz and Alberto Lopez Castellano, 69-96. Granada: Universidad de Granada.

Gudynas, Eduardo. 2010. "Agropecuaria y nuevo extractivismo bajo los gobiernos progresistas de América del Sur." Territorios 5: 37-54.

Guzman, Jose Miguel, George Martine, Gordon MacGranahan, Daniel Schensul, and Cecilia Tacoli. 2009. Population Dynamics and Climate Change. UNFPA/IIED.

Hale, Lynne. 2000. "Achieving Integration in Coastal Management: The Challenge of Linking National and Local Levels of Government." Korea Observer 30: no pagination.

Hamzan, Amran, and Mark P. Hampton. 2013. "Resilience and Non-Linear Change in Island Tourism." Tourism Geographies 15 (1): 43-67.

Hannah, Mathew. 2011. "Biopower, life, and left politics." Antipode 43 (4): 1034-1055.

Haq, Bilal U., Syed M. Haq, Gunnar Kullemberg, and Jan H. Stel. 1997. Coastal Zone Management Imperative for Maritime Developing Nations. Dordrecht: Kluwer Academic Publisher.

Hardt, Michael, and Anthony Negri. 2004. The Multitude. War and Democracy in the Age of Empire. New York: The Penguin Press.

Heemskerk, Matthew. 2001. "National Efforts at Integrated Coastal Zone Management: The Canadian, Australian and New Zealand Experiences." Dalhousie Journal of Legal Studies 1: 158-181.

Herrera, Paul A., Guido Van Huylenbroeck, and Ramon Espinel. 2006 . "Asymmetric Information on the Provision of Irrigation through a Public Infrastructure: The 
Case of the Peninsula of Santa Elena, Ecuador." Water Resource Management 20: 431-447.

Holling, Crawford S. 2004. "From Complex Regions to Complex Worlds." Ecology And Society 9 (11): no pagination.

Holling, Crawford S. 2001. "Understanding the Complexity of Economic, Ecological, and Social Systems." Ecosystems 4: 390-405.

Holling, Crawford S. 1996. "Engineering Resilience vs. Ecological Resilience." In Engineering within Ecological Constrains, by Peter E. Schulze, 31-43. Washington D.C.: National Academy of Engineering.

Holling, Crawford S. 1973. "Resilience and Stability of Ecological Systems." Annual Review of Ecology and Systematics 4 (1): 1-23.

Hughes, Terence Patrick, David R. Bellwood, Darl Folke, Robert S. Steneck, and James Wilson. 2005. "New paradigms for supporting the resilience of marine ecosystems." Trends in Ecology \& Evolution 20 (7): 380-386.

IRF. 1996. Tourism and Coastal Resources Degradation in the Wider Caribbean. St. Thomas: Island Resources Foundation.

Joseph, Jonathan. 2013. "Resilience as embedded neoliberalism: a governmentality approach." Resilience. International Policies, Practices and Discourses 1 (1): 3852.

Kates, Robert W., Thomas M. Parris, and Anthony A. Leiserowitz. 2005. "What is Sustainable Development? Goals, Indicators, Values, and Practice." Environment Science and Policy for Sustainable Development 47 (3): 8-21.

Kearney, John, Fikret Berkes, Anthony Charles, Evelyn Pinkerton, and Melanie Weber. 2007. "The Role of Participatory Governance and Community-Based Management in Integrated Coastal and Ocean Management in Canada." Coastal Management 35: 79-104.

Kueffer, Christoph. 2015. "Ecological Novelty: Towards an Interdisciplinary Understanding of Ecological Change in the Anthropocene." In Grounding Global Climate Change. Contributions from the social and cultural sciences, by J. Greschke and J. Tischler, 19-37. New York: Springer.

Lansing, Stephen. 1991. Priests and Programmers: Technologies of Power in the Engineered Landscape of Bali. Princeton: Princeton University Press.

Larsen, Rasmus Klocker, Emma Calgaro, and Frank Thomalla. 2011. "Governing resilience building in Thailand's tourism-dependent coastal communities: 
Conceptualising stakeholder agency in social-ecological systems." Global Environmental Change 481-491.

Latorre, Sara, Katharine N. Farrell, and Joan Martinez-Alier. 2015. "The commodification of nature and socio-environmental resistance in Ecuador: An inventory of accumulation by dispossession cases, 1980-2013." Ecological Economics 1 (16): 58-69.

Latour, Bruno. 1999. Pandora's Hope. Essays on the Reality of Science Studies. Harvard: Harvard University Press.

León, Vanessa. 2013. "Aproximacion al Turismo Residencial en la Provincia de Santa Elena, Ecuador." Revista Retos 6: 127-138.

Li, Tanya. 2007. The Will to Improve. Governmentality, Development, and the Practice of Politics. Duke: Duke University Press.

Luke, Timothy W. 2006. "Geo-Power and Eco-Knowledge in the Discourses of Contemporary Environmentalism." In The Environment in Anthropology. A Reader in Ecology, Culture, and Sustainable Living, by Richard Wilk and Nora Haenn, 257-269. New York: New York University Press.

López, María Fernanda. 2015. "El sistema de planificación y el ordenamiento territorial para Buen Vivir en el Ecuador." Geousp-Espaço e Tempo 19 (2): 196-311.

Macdonald, Laura, and Arne Ruckert. 2009. Post-Neoliberalism in the Americas. Great Britain: Palgrave Macmillan.

Mahmood, Saba. 2005. Politics of Piety. The Islamic revival and the feminist subject. Princeton and Oxford: Princeton University Press.

McBride, Randolph, and Christopher T. Seminack. 2017. "Coastal Zone." In The International Encyclopedia of Geography: People, the Earth, Environment, and Technology, by D. Richardson, N. Castree, M. F. Goodchild, A. Kobayashi, W. Liu and R. A. Martson, 2-8. Willie Online Library.

McEvoy, Darryn, Hartmut Fünfgeld, and Karyn Bosomworth. 2013. "Resilience and Climate Change Adaptation: The Importance of Framing." Planning, Practice \& Research (Oceans Conservations Report Series) 28 (3): 280-293.

McGranahan, Gordon, Deborah Balk, and Bridget Anderson . 2007. "The rising tide: assessing the risks of climate change and human settlements in low elevation coastal zones." Environment and Urbanization 9 (1): 17-37.

Meltzer, Evelyne. 1998. International Review of Integrated Coastal Zone Management. Ottawa: Oceans Conservation Report Series. 
Ministerio de Turismo. 2010. "Plan Integral de Marketing de Ecuador PIMTE 2014." Quito: Ministerio de Turismo del Ecuador, July 07.

Morales-Urrutia, Ximena, Diana Morales-Urrutia, and Eduardo Hong-Hong. 2017. "Emprendimiento social en el sector del turismo comunitario: una primera aproximación al caso de las comunidades indígenas del Ecuador." RITUR. Revista Iberoamericana de Turismo 7 (2): 105-120.

MRE. 2011. Informe Nacional del Progreso en la Implementación del Marco de Acción de Hyogo (2009-2011). Quito: Ministerio de Relaciones Exteriores.

MRE. 2007. Informe Nacional del Progreso en la Implementación del Marco de Acción de Hyogo. Quito: Ministerio de Relaciones Exteriores.

Mulligan, Martin, Wendy Steele, Lauren Rickards, and Hartmut Fünfgeld. 2016. "Keywords in planning: what do we mean by 'community resilience'?" International Planning Studies 21 (4): 1-13.

Neumann, Barbara, Athanasios Vafeidis, Juliane Zimmerman, and Robert J. Nicholls. 2015. "Future Coastal Population Growth and Exposure to Sea-Level Rise and Coastal Flooding - A Global Assessment." PLoS ONE 10 (3): 1-37.

NicoPenínsula. 2018. "Libertador Bolívar en Emergencia." September 14.

Ochoa, Emilio, Stephen Olsen, and N. Windevoxhel. 2001. Avances del Manejo Costero Integrado en PROARCA/Costas. Guayaquil: Ecocostas.

Ocles, Alexandra, interview by Radio Pública. 2018. La Secretaría de Gestión de Riesgos se perpara para su reordenamiento (October 11).

O'Connell, James F. 2010. "Shoreline Armoring Impacts and Management Along the Shores of Massachusetts and Kauai, Hawaii." In Puget Sound Shorelines and the Impacts of Armoring - Proceedings of a State of the Science Workshop,May 2009S, by Hugh Shipman, Megan N. Dethier, Fuy Gelfenbaum, Kurt L. Fresh and Richard S. Dinicola, 65-76. Reston, Virginia: U.S. Geological Survey Scientific Investigation Report 2010-5245.

ODEPLAN. 2001. Programa Nacional de Prevención-Mitigación de Desastres Naturales $y$ Gestion de Riesgos en Ecuador. Quito: Oficina de Planificación de la Presidencia de la República de Ecuador.

O'Donnel, Erin, and Julia Talbot-Jones. 2018. "Creating legal rights for rivers: lessons from Australia, New Zealand, and India." Ecology and Society 23(1) (7): no pagination.

Odum, Howard T., and Jan E. Arding. 1991. Emergy Analysis of Shrimp Mariculture in Ecuador. Narragansett, RI: Coastal Resources Center, University of Rhode Island. 
Ochoa, Emilio. 1995. Manejo Costero Integrado en Ecuador. Guayaquil: Gráficas Paz

O'Hare, Paul, and Ian White. 2013. "Deconstructing Resilience: Lessons from Planning Practice." Planning, Practice \& Research 3: 275-279.

Olsen, Stephen. 2003. Crafting Coastal Governance in a Changing World. Edited by Stephen Olsen. Rhode Island: Coastal Resource Center - University of Rhode Island.

Olsen, Stephen. 1991. Ecuador's Pioneering Initiative in Integrated Coastal Management. Narragansett: The Coastal Resource Center, University of Rhode Island.

Olsen, Stephen, and Patrick Christie. 2000. "What Are We Learning from Tropical Coastal Management Experiences?" Coastal Management 28 (1): 5-18.

Olsen, Stephen, Glenn G. Page, and Emilio Ochoa. 2009. The Analysis of Governance Responses to Ecosystem Change: A Handbook for Assembling a Baseline. LOICZ Reports \& Studies No. 34, Geesthacht: GKSS Research Center.

Olsen, Stephen, Jon G. Sutinen, Lawrence Juda, Timothy M. Hennesey, and Thomas A. Grigalunas. 2006. A Handbook on Governance and Socioeconomics of Large Marine Ecosystems. Narrangansett: University of Rhode Island.

Olsen, Stephen, Luis Arriaga, Emilio Ochoa, and Donald Robadue Jr. 1997. "Ecuador's Participatory and Adaptive Approach to Integrated Coastal Management." In Coastal Zone Management Imperative for Marine Developing Nations, by Bilal Haq, Syed M. Haq, Gunnar Kullenberg and Jan H. Stel, 253- 286. Dordrecht: Kluwer Academic Publishers.

Olsson, Per, Carl Folke, and Fikret Berkes. 2004. "Adaptive Comanagement for Building Resilience in Social-Ecological Systems." Environmental Management 34 (1): 75-90.

OPS. 2000. Fenomeno El Niño, 1997-1998. Washington D.C.: Organización Panamericana de Salud.

Ordoñez, Martha and Flavio Marco. 2005. Políticas de empleo en la planificación turistica local de Ecuador. Herramientas para su formulación. Santiago de Chile: UN-CEPAL

Ostrom, Elinor. 2009. "A General Framework for Analyzing Sustainability of SocialEcological Systems." Science 325 (5939): 419-421.

Ostrom, Elinor. 2008. "Institutions and the Environment." Institute of Economic Affaris 24-31. 
Ostrom, Elinor, and Marco A. Janssen. 2004. "Multi-level Governance and Resilience of Social-Ecological Systems." In Globalisation, Poverty, and Conflict, by Max Spoor, 239-259. Netherlands: Kluwer Academic Publishers.

Ostrom, Elinor, Marco A. Janssen, and John M. Anderies. 2007. "Going beyond Panaceas." Workshop in Political Theory and Policy Analysis. Worcester: Proceedings of the National Academy of Sciences of the US PNAS. 15176-8.

Padilla, Nadia. 2015. "The environmental effects of Tourism in Cancun, Mexico." International Journal of Environmental Sciences 6 (1): 282-294.

Pazmiño, Pablo Manrique, Juan Manuel Barragan, and Javier García. 2018. "Progress on coastal management in Ecuador (2007-2017)." Environmental Science and Policy 90: $135-147$.

Peck, Jaime, and Adam Tickell. 2002. "Neoliberalizing Space." Antipode 380 - 405.

Pelling, Mark, and Kathleen Dill. 2006. "'Natural' Disasters as Catalysts of Political Action." ISP/NSC Briefing Paper 06/01 4-6.

Philo, Chris. 2007. "'Bellicose history" and "local discursivities": An archaeological reading of Michel Foucault's Society must be defended." In Space, Knowledge, and Power: Foucault and geography, by J. Crampton and S. Elden, 341-368. Burlington: Ashgate Publishing Company.

Philo, Chris. 1992. "Foucault's geography." Environment and Planning D: Society and Space 10 (2): 137-161.

Pineo, Ronn. 2007. Ecuador and the United States. Useful Strangers. Georgia: University of Georgia Press.

CRMP. 1993. Plan de Manejo de la ZEM San Pedro-Valdivia-Manglaralto. Guayaquil: Programa de Manejo de Recursos Costeros.

Post, Jan C., and Carl G. Lundin. 1996. Guidelines for Integrated Coastal Zone Management. Environmentally Sustainable Development Studies and Monographs Series No. 9, Washington D.C.: The International Bank.

Povinelli, Elizabeth. 2016. Geontologies: A Requiem to Late Liberalism. Durham: Duke University Press.

Rabinow, Paul. 2010. The Foucault Reader. New York: Vintage Books.

Rabinow, Paul, and Nikolas Rose. 2006. "Biopower Today." BioSocieties 1: 195-217.

Radcliffe, Sarah. 2012. "Development for a postneoliberal era? Sumak kawsay, living well and the limits to decolonisation in Ecuador." Geoforum 43: 240-249. 
Ramírez, Yorgi. 2013. El derecho a las vacaciones en el Ecuador El descanso y el ocio: Guayaquil: Ramírez Ediciones

Rappaport, Roy. 1967. Pigs for the Ancestors: Ritual in the Ecology of a New Guinea People. New Haven: Yale University Pres.

Rebotier, Julien. 2016. El Riesgo y su Gestión en Ecuador. Una Mirada de Geografía Social y Política. Quito: Pontificia Universidad Católica de Ecuador.

Reid, Julian. 2018. "Neoliberalism, Development and Resilience." In The SAGE Handbook of Neoliberalism, by Damien Cahill, Melinda Cooper, Martin Konings and David Pimrose, 644-653. New York: Sage Publications Ltd.

Reid, Julian. 2017. "The Risk of Resilience to Indigenous Peoples." Arctic Journal no pagination.

Reid, Julian. 2013. "Interrogating the Neoliberal Biopolitics of the SustainableDevelopment-Resilience nexus." International Political Sociology 7: 353-368.

Rentería, Willington. 2007. "Generacion de Mapas Digitales para Machala y Salinas basados en el Tsunami Historico de 1953." Acta Oceanográfica del Pacífico 14 (1): 207-216.

Robadue, Ronald Jr. 1995. Eight Years in Ecuador: The Road to Integrated Coastal Management. Narragansett, RI: Coastal Resources Center, University of Rhode Island.

Robbins, Paul, John Hintz, and Sarah A. Moore. 2014. Environment and Society. A Critical Introduction. West Sussex: Willey Blackwell.

Rose, Nikolas. 1996a. "The Death of the Social? Re-figuring the territory of Government" Economy and Society 25 (3): 327-356.

Rose, Nikolas. 1996b. "Governing "advanced" liberal societies." In Foucault and Political Reason, by Andrew Barry, Thomas Osborne and Nikolas Rose, 41-42. London: Routledge.

Roux, Fanny. 2013. Turismo comunitario ecuatoriano, conservacion ambiental y defensa de los territorios. Quito: Federación Plurinacional de Turismo Comunitario del Ecuador (FEPTCE).

Ruiz, Esteban, Macarena Hernandez, Agustīn Coca, Pedro Cantero, and Alberto Del Campo. 2008. "Turismo comunitario en Ecuador. Comprendiendo el communitybased tourism desde la comunidad." Pasos. Revista de Turismo y Patrimonio Cultural 6 (3): 399-418. 
Sánchez, Enrique. 2015. Consultoría para la Ejecución de los Estudios para el Diseño de la Protección Costera del Nuevo Malecón de Libertador Bolívar Perteneciente al Cantón Santa Elena. Consultancy, Santa Elena: Municipio de Santa Elena.

Sadeghi, Kabir, Idris Shuaibu, and Abdullahi Hamza. 2019. "Classification of Seawalls and their failure: An overview." Academic Research International 9 (1): 12-19.

Said, Edward. 1978. Orientalism. London: Routledge.

Santos, José Luis. 2006. "El conocimiento sobre El Evento de El Niño: Una perspectiva local dentro de un contexto global." Revista Tecnológica ESPOL 19 (1): 143-152.

Schmidt, Jessica. 2015. "Intuitively neoliberal? Towards a critical understanding of resilience governance." European Journal of International Relations 21 (2): 402426.

Scoppetta, Cecilia. 2016. "“Natural" disasters as (neo-liberal) opportunity? Discussing post-hurricane Katrina urban regeneration in New Orleans." TeMA: Journal of Land Use, Mobility and Environment 9 (1): 25-42.

Scott, James. 1998. Seeing Like a State. How Certain Schemes to Improve the Human Condition Have Failed. Haven: Yale University Press.

SENPLADES. 2017. Plan de Ordenamiento del Espacio Marino Costero. Quito: Secrtaría Nacional de Planificación y Desarrollo.

SENPLADES. 2013. Good Living National Plan 2013-2017. Quito: Secretaría Nacional de Planificación y Desarrollo.

SENPLADES. 2009. National Plan for Good Living 2009-2013. Building a Plurinational and Intercultural State. Quito: Secretaría Nacional de Planificación y Desarrollo SENPLADES.

SENPLADES. 2007. Plan Nacional del Buen Vivir 2007-2010. Quito: Secretaría Nacional de Planificación y Desarrollo.

Sharma, Aradhana, and Akhil Gupta. 2006. The Anthropology of the State: A Reader. Malden: Blackwell Publishing.

Shipman, Hugh, Megan N. Dethier, Guy Gelfenbaum, Kurt L. Fresh, and Richard Dinicola. 2010. Puget Sound Shorelines and the Impacts of Armoring. Reston: US Geological Survey.

Simpson, Audra. 2008. "Subjects of Sovereingty: Indigeneity, The Revenue Rule, and Juridics of Failed Consent." Law and Contemporary Problems 71: 107-124.

Slater, David. 2004. Geopolitics and the Post-Colonial. Malden: Blackwell Publishing. 
Small, Christopher, and Robert J. Nicholls. 2003. "A Global Analysis of Human Settlement in Coastal Zones." Journal of Coastal Research 19 (3): 584-599.

Smith, Valerie, and William R. Eadington. 1992. Tourism Alternatives. Potentials and Problems in the Development of Tourism. Philadelphia: University of Pennsylvania Press.

SNGR. 2014. Ecuador: Avances en la Gestión de Riesgos 2008 - 2013. Quito: Secretaría de Gestión de Riesgos.

SNGR. 2013. Informe Nacional del Progreso en la Implementación del Marco de Acción de Hyogo (2011-2013). Quito: Secretaría Nacional de Riesgos.

SNGR. 2012. Ecuador: Basic References for Risk Management 2013-2014. Country Document, Quito: SGR/ECHO/UNISDR.

Solberg, Scott, David Hale, and Juan Benavides. 2003. Natural Disaster Management and the Road Network in Ecuador: Policy Issues and Recommendations. Working Paper, Washington D.C.: Interamerican Development Bank.

Stothert, Karen E. 1985. "The Preceramic Las Vegas Culture of Coastal Ecuador." American Antiquity 50 (3): 613-637.

Swyngedouw, Erick. 2004. Social Power and the Urbanization of Water. Flows of Power. Oxford: Oxford University Press.

Tang, Zhenghong, Michael K. Lindel, Carla Prater, Ting Wei, and Christopher M. Hussey. 2010. "Examining Local Coastal Zone Management Capacity in U.S. Pacific Coastal Counties." Coastal Management 39 (2): 105-132.

Thompinks, Emma L., and Neil W. Adger. 2003. Building resilience to climate change through adaptive management of natural resources. Working Paper 27, Norwich: Tyndal Centre for Climate Change Research, no pagination.

Trouillot, Michel-Rolph. 2001. "The Anthropology of the State in the Age of Globalization Close Encounters of the deceptive kind." Current Anthropology 42 (1): 125-138.

Tuaza, Carlos, and Carlos Saenz. 2014. "Federación de las Comunas de la Provincia de Santa Elena: Capacidad de Agencia y Conflictos." Ciencias Pedagógicas e Innovación 25-32.

UN. 2002. Report of the World Summit on Sustainable Development. New York: United Nations.

UN. 1972. Declaration of the United Nations Conference on the Human Environment. Stockholm: United Nations. 
UNDP. 2013. Climate Risk Management in Ecuador. United Nations Development Programme; Bureau for Crisis Prevention and Recovery (BCPR), New York: UNDP BCPR.

UNDRR. 2019. UN Office of Disaster and Risk Reduction. Accessed June 13, 2019. https://www.unisdr.org/.

UNESCO. 2006. Sixty Years of Science at UNESCO 1945. Paris: UNESCO Publishing.

UNISDR-SNGR. 2014. IV Sesión de la Plataforma Regional para la Reducción del Riesgo de Desastres de las Américas. Session Report, Guayaquil: UNISDR.

UNWCED. 1987. Report of the World Commission on Environment and Development: Our Common Future. Oxford: Oxford University Press.

Walker, Brian, Crawford S. Holling, Stephen Carpenter, and Anna Kinzing. 2004. "Resilience, Adaptability, and Transformability in Social-ecologicall Systems." Ecology and Society 9 (2): no pagination.

Walker, Jeremy, and Melinda Cooper. 2011. "Genealogies of resilience: From systems ecology to the political economy of crisis adaptation." Dialogue Security. Special Issue on The Global Governance of Security and Finance 42 (2): 143-160.

Walsh, Catherine. 2015. "Affirmative action(ing)s and postneoliberal movement in South America and Ecuador." Cultural Dynamics 27 (1): 19-41.

Warren, Jonathan W. 2001. Racial Revolutions. Antiracism \& Indian Resurgence in Brazil. Durham: Duke University Press.

Weaver, David. 2011. "Small can be Beautiful, but Big can be Beautiful Too-And Complementary: Towards Mass/Alternative Tourism Synergy." Tourism Recreation Research 36 (2): 186-189.

Wesche, Rolf, and Andy Drumm. 1999. Defending our rainforest. A guide to community based tourism in the Ecuadorian Amazon. Quito: Acción Amazónica \& University of Ottawa.

Whitehead, Mark, Rhys Jones, and Martin Jones. 2007. The Nature of the State. Excavating the Political Ecologies of the Modern State. Oxford: Oxford University Press.

Wiedman, Dennis. 2012. "Upholding Indigenous Freedoms of Religion and Medicine. Peyotists at the 1906-1908 Oklahoma Constitutional Convention and First Legislature." American Indian Quarterly 36 (2): 215-246. 
Wiedman, Dennis. 2010. "Global Marketing of Indigenous Culture: Discovering Native America with Lee Tiger and the Florida Miccosukee." American Indian Culture and Research Journal 34 (3): 1-26.

Wolf, Teodoro. 1892. Geografía y Geología del Ecuador. Leipzig: F.A. Brockhaus.

Zambrano, David. 2011. "El Ecoturismo Comunitario en Manglaralto y Colonche." In Trece Experiencias de Desarrollo Endogeno en Ecuador, by Victor Hugo Torres, 181 - 192. Guayaquil: ditorial Universitaria Abya-Yala. 
APPENDICES 


\section{Appendix 1 - IRB approved interview templates}

\section{Interview group A: Risk Management Secretariat officials and technicians}

Since 2007, Ecuador created a National Risk Management System, I would like to know, in general, how that system worked and still works.

a) How was risk management conceptualized before 2007 ?

b) How did risk management operate before 2007 ?

c) Since 2007, how does the government conceptualize risk management? d) What was the main concern of the government in conceptualizing risk management?

d) Was risk management related to environmental sustainability, climate change, natural disasters and development?

e) How did the government connect the protection, development and welfare of the environment?

f) Was the notion of "Sumak-Kawsay" (Good Living) the main link to implement risk management policies?

g) How was the process of creating a complete risk management system in the country?

h) Do risk management policies incorporate concepts of resilience? If so, how does RMS incorporate resilience in Ecuadorian policies?

i) Many people talk about resilience, what does resilience mean to you? How do you define resilience?

Risk management in Ecuador includes international resilience frameworks. How was resilience conceptualized in Ecuador?

a) How did the RMS incorporate resilience building into national risk management strategies?

b) What was the relationship between the creation of risk management frameworks and international resilience? What did this relationship respond to?

c) How did RMS create resilience policies?

d) How did the RMS operationalize resilience policies?

When addressing national risk management as a whole, how did it relate to other government spheres, particularly development plans?

a) Are risk management and resilience programs connected to national development strategies?

b) If yes, what happens to tourism development? How does RMS connect the Risk Management System with tourism development strategies?

c) Do you work according to the officials of the Ministry of Tourism? What project do you manage together with tourism officials?

d) At the local level, particularly in the Province of Santa Elena, how does RMS work with officials / technicians of the Ministry of Tourism? 
Moving to the local level, how were the concepts of risk management and resilience introduced in coastal communities, especially in the province of Santa Elena?

a) How did RMS approach coastal communities?

b) What did Santa Elena's coastal communities know about risk management and resilience?

c) What were the methods used by RMS technicians / technicians to promote resilience building?

d) What social, political or cultural factors limited the implementation of resilience policies?

e) How did the Santa Elena communities get involved in these national initiatives?

f) What type of rejections did you find during the implementation process?

g) What do you think was the most problematic during the implementation process?

h) Do risk / resilience management policies limit cultural or environmental knowledge among the communities of Santa Elena?

Continuing at the local level, what are the effects of implementing risk management and resilience programs among coastal communities?

a) What are, in your opinion, the benefits of implementing risk management / resilience programs among the coastal communities of Santa Elena? What are its limitations?

b) In your opinion, the coastal communities of Santa Elena win or lose with risk / resilience management programs?

c) How do you conceptualize resilience?

\section{Interview group B: Ministry of tourism officials and technicians}

Tourism strategies in Ecuador began in the late 90s, what are the differences with current tourism strategies?

a) How was tourism conceptualized before 2007 ?

b) How did tourism development work before 2007 ?

c) Since 2007, how does the government conceptualize tourism development strategies?

d) What was the main concern of the government in conceptualizing tourism development?

e) Was tourism development related to environmental sustainability, climate change, natural disasters and risk management?

f) How did the government connect tourism development, environmental sustainability and well-being?

g) Was the notion of "Sumak-Kawsay" (Good Living) the main link to implement tourism development policies?

h) How did the Ministry of Tourism incorporate tourism development strategies into national risk management strategies? 
Moving to the local level, how were tourism development strategies introduced in coastal communities, especially in the province of Santa Elena?

a) How does tourism operate in coastal communities before 2007?

b) How did tourism officials/technicians' approach coastal communities?

c) What did the coastal communities expect from tourism officials / technicians?

d) What were the methods used by tourism officials / technicians to promote tourism development?

e) How do coastal communities receive these national initiatives?

f) What type of rejections did you find during the implementation process?

g) What do you think was the most problematic during the implementation process?

h) Do national tourism policies restrict cultural or environmental knowledge among the communities of Santa Elena?

The coastal communities in Santa Elena are prone to climatic phenomena such as El Niño with its rainfall, La Niña brings severe droughts to the area, the Colonche Mountains have been deforested for quite some time, communities fight for water in the dry season, and so on.

a) Are tourism development strategies linked to risk management and resilience strategies?

b) How do tourism development strategies connected to RMS connect to the Risk Management System?

c) Do you work according to RMS officials? What project do you manage with RMS officials?

d) At the local level, particularly in the Province of Santa Elena, how do Tourism officials / technicians operate with RMS officials / technicians?

Continuing at the local level, what are the effects of implementing risk management and resilience programs among coastal communities?

a) What are, in your opinion, the benefits of implementing risk management / resilience programs among the coastal communities of Santa Elena? What are its limitations?

b) In your opinion, the coastal communities of Santa Elena win or lose with risk / resilience management programs?

c) How do you conceptualize resilience?

\section{Interview group $\mathrm{C}$ : leaders and community members}

Ecuadorian governments have been working in Santa Elena for a while, bringing initiatives towards well-being.

a) What are the benefits that the government has brought to your community in recent years?

b) What are the limitations that the government has brought to your community in recent years?

c) Before 2007, how did the community benefit from government initiatives? 
d) Which government officials / technicians have been closest to the community?

What about the risk management officers / technicians, have they been working near the community?

a) What was your main objective?

b) How did you implement risk management / resilience programs in your community?

c) What do you know about RMS programs? What were these risk management programs about?

d) Have you participated in any risk management program? If yes, what was its main function? If not, do you know someone who participated in those programs? e) Do risk management programs include concepts such as resilience, development, wellbeing?

e) Many people talk about resilience, what does resilience mean to you? How do you define resilience?

f) What benefits does risk management and / or resilience bring to the community?

g) What limitations does risk management and / or resilience bring to the community?

h) Does the risk and / or resilience management program limit its own ways of managing environmental threats?

El Niño phenomenon has a constant impact on this area with severe rains and rising tides on the coast.

a) What do you know about El Niño?

b) Do you remember when El Niño severely affected the community?

c) Can you detail how the community faced and survived? What damage did you remember from such a catastrophe? Were they injured, injured?

d) Did the community receive emergency government assistance? Was it a quick response? How was such help? How long did the government provide emergency help and help?

e) What about the NGOs? Did the community have any help or support from an NGO? If yes, did they respond quickly? How was such help?

f) Does the community still have a consequence of such a catastrophe? Infrastructure, health, economic?

Connecting your experience on the El Niño phenomenon with risk management and resilience programs recently operationalized by the Ecuadorian government,

a) Is the community now prepared to face the impacts of El Niño? Are you more or less prepared than before the risk / resilience management training?

b) What is the difference between before and after risk management officials trained the community to face climate threats?

c) Is there any social, cultural or political factor that limits the implementation of resilience policies in your community? 
d) What type of rejections did you find during the implementation process?

e) What do you think was the most problematic during the implementation process?

f) Are risk management and resilience programs connected to the development of tourism in your community? How?

Tourism has become an alternative to its community. Can you tell me how your community participated in the development of tourism?

a) When did the community realize that tourism would improve their income?

b) Did tourism development begin before or after 2007 ?

c) How does the community organize tourism services?

d) Does the community measure the income of tourism? How does the community measure tourism activities?

e) Does the community participate in tourism development by itself or does the community respond to government strategies?

f) Does the community have any associations to develop tourism?

g) Has the community collaborated with any foreign development assistance? NGO? Ecuadorian Government?

What about the officials / technicians of the Ministry of Tourism, have been working near the community?

a) What was your main objective?

b) How did you implement tourism strategies and programs in your community?

c) What do you know about tourism strategies and programs? What were these tourist programs about?

d) Have you participated in any tourism development program? If yes, what was its main function? If not, do you know someone who participated in those programs?

e) Do tourism programs include concepts such as resilience or well-being?

f) What benefits have tourism programs brought to the community?

g) What restrictions have tourism programs brought to the community?

h) Does tourism restrict your own ways of managing environmental threats?

i) Does tourism restrict your cultural values? 


\section{Appendix 2 - Matrix of codes}

\begin{tabular}{|c|c|c|c|}
\hline Code & Sub-code & Abbreviation & Definition \\
\hline \multirow[t]{3}{*}{$\begin{array}{l}\text { Neoliberal } \\
\text { practices }\end{array}$} & & $\begin{array}{c}\text { NEO- } \\
\text { PRACTICES }\end{array}$ & $\begin{array}{l}\text { Plans, Agendas, Laws, rules, generated or } \\
\text { applied before the year } 2007\end{array}$ \\
\hline & $\begin{array}{l}\text { Neoliberal risk } \\
\text { management }\end{array}$ & NEO-RM & $\begin{array}{l}\text { Plans, Agendas, Laws, rules, specifically } \\
\text { addressing to Disaster and Risk } \\
\text { Management, Mitigation, Prevention, and } \\
\text { Response before the year } 2007\end{array}$ \\
\hline & $\begin{array}{l}\text { Neoliberal } \\
\text { Development }\end{array}$ & NEO-DEV & $\begin{array}{l}\text { Plans, Agendas, Laws, rules, specifically } \\
\text { addressing to development (in all fields) } \\
\text { before the year } 2007\end{array}$ \\
\hline \multirow[t]{3}{*}{$\begin{array}{l}\text { Anti- } \\
\text { neoliberal } \\
\text { practices }\end{array}$} & & $\begin{array}{l}\text { ANTI-NEO- } \\
\text { PRACTICES }\end{array}$ & $\begin{array}{l}\text { Plans, Agendas, Laws, rules, generated or } \\
\text { applied after the year } 2007\end{array}$ \\
\hline & $\begin{array}{l}\text { Anti-neoliberal } \\
\text { disaster } \\
\text { management }\end{array}$ & $\begin{array}{l}\text { ANTI-NEO- } \\
\text { RM }\end{array}$ & $\begin{array}{l}\text { Plans, Agendas, Laws, rules, specifically } \\
\text { addressing to Disaster and Risk } \\
\text { Management, Mitigation, Prevention, and } \\
\text { Response after the year } 2007\end{array}$ \\
\hline & $\begin{array}{l}\text { Anti-neoliberal } \\
\text { development }\end{array}$ & $\begin{array}{l}\text { ANTI-NEO- } \\
\text { DEV }\end{array}$ & $\begin{array}{l}\text { Plans, Agendas, Laws, rules, specifically } \\
\text { addressing to development (in all fields) } \\
\text { after the year } 2007\end{array}$ \\
\hline $\begin{array}{l}\text { Coastal } \\
\text { Management } \\
\text { Program I }\end{array}$ & & CRMP-I & $\begin{array}{l}\text { Plans, Agendas, laws, rules regarding the } \\
\text { Coastal Resource Management Program } \\
\text { before } 2003\end{array}$ \\
\hline $\begin{array}{l}\text { Coastal } \\
\text { Management } \\
\text { Program II } \\
\end{array}$ & & CRMP-II & $\begin{array}{l}\text { Plans, Agendas, laws, rules regarding the } \\
\text { Coastal Resource Management Program } \\
\text { after } 2004\end{array}$ \\
\hline $\begin{array}{l}\text { ENSO 1997- } \\
1998\end{array}$ & & & $\begin{array}{l}\text { Plans, Agendas, laws, rules, responses } \\
\text { regarding ENSO 1997-1998 }\end{array}$ \\
\hline $\begin{array}{l}\text { Resilience } \\
\text { practices }\end{array}$ & & RES-PRACT & $\begin{array}{l}\text { How do people practice resilience in } \\
\text { Ecuador }\end{array}$ \\
\hline $\begin{array}{l}\text { Resilience } \\
\text { Definition }\end{array}$ & & RES-DEFIN & $\begin{array}{l}\text { Definitions of resilience, particularly } \\
\text { provided by interviewees and Ecuadorian } \\
\text { policies of RM }\end{array}$ \\
\hline $\begin{array}{l}\text { Resilience } \\
\text { perceptions }\end{array}$ & & RES-PERCEP & $\begin{array}{l}\text { How people perceive resilience, } \\
\text { vulnerability, risk }\end{array}$ \\
\hline $\begin{array}{l}\text { Other } \\
\text { resilience } \\
\text { practices }\end{array}$ & & RES-OTHER & $\begin{array}{l}\text { Any practice not included in formal } \\
\text { practices of resilience building }\end{array}$ \\
\hline $\begin{array}{l}\text { Resilience } \\
\text { Building }\end{array}$ & & RES-BUILD & $\begin{array}{l}\text { Plans, Agendas, laws, rules regarding the } \\
\text { making community more resilient, less } \\
\text { vulnerable }\end{array}$ \\
\hline $\begin{array}{l}\text { Resilience } \\
\text { Building } \\
\text { Approach }\end{array}$ & & $\begin{array}{l}\text { RES-BUILD- } \\
\text { APPROACH }\end{array}$ & $\begin{array}{l}\text { Ideas, perceptions, criteria that reinforce } \\
\text { the construction of more resilient } \\
\text { communities or individuals }\end{array}$ \\
\hline
\end{tabular}




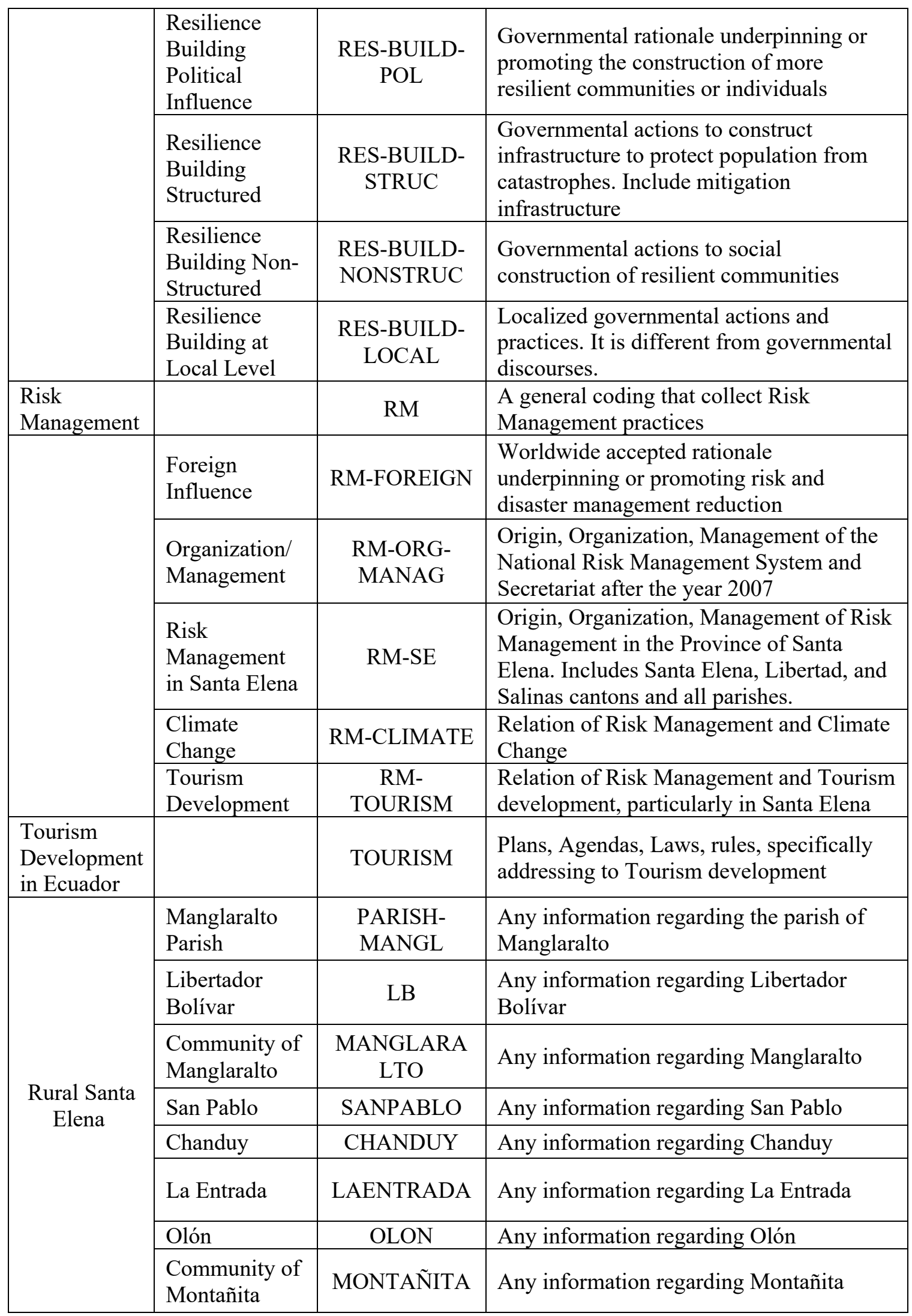


VITA

\section{VANESSA LEÓN LEÓN}

Born, Guayaquil, Ecuador

\section{EDUCATION}

$2014-2019$

$\mathrm{Ph}$. D. Candidate, Global and Sociocultural Studies.

Florida International University.

Miami, Fl., USA

$2007-2009$

Master in Tourism Management and Planning. University of Alicante

Alicante, Spain

$1998-1992$

B.A. Business Administration.

University "Vicente Rocafuerte"

Guayaquil, Ecuador

\section{PUBLICATIONS AND PRESENTATIONS}

León V. (Forthcoming). Hybridizing beaches through local hybridized tourism development. A different approach to sustainable development. Accepted and in press for 2020 at Mathematical Advances Towards Sustainable Environmental Systems - Earth Systems Protection. Volume edited by James Furze, Safanah Raafat, Cecil Kelly Swing, Bina Sengar and Saeid Eslamian. Springer

León, V., Cando, M. I., \& Ramírez, Y. (Forthcoming). “"A pesar de todo, vamos por buen camino.' Más allá de la cooperación al desarrollo.” Accepted and in press for 2020 in Revista Estudios y Perspectivas en Turismo.

León V. 2019. "Community-based tourism at risk byglobal warming." Paper Presentation. Third Conference of ADLAF Andean Countries Work Group. Erlagen, Germany

León, V. 2019. "Beaches, tourism development, and increasing local threats." Paper presentation. American Anthropologists Association Annual Meeting, Vancouver, Canada.

León, V. 2019. "Beach, Tourism, and Coastal Protection.” Paper presentation. The Latin American Studies Association, Boston, USA

León, Vanessa. 2013. "Aproximacion al Turismo Residencial en la Provincia de Santa Elena, Ecuador." Revista Retos 6: 127-138. 